VITOR GEROMEL

\title{
TRIBUNAIS INTERNACIONAIS E O PODER JUDICIÁRIO BRASILEIRO
}

\author{
Dissertação de Mestrado \\ Orientador: Professor Associado Wagner Menezes
}

FACULDADE DE DIREITO DA UNIVERSIDADE DE SÃO PAULO São Paulo 


\section{VITOR GEROMEL}

\section{TRIBUNAIS INTERNACIONAIS E O PODER JUDICIÁRIO BRASILEIRO}

Dissertação depositada como requisito de aprovação para obtenção do título de Mestre em Direito Internacional pelo Programa de Pós-Graduação da Faculdade de Direito da Universidade de São Paulo, desenvolvida sob a orientação do Professor Associado Wagner Menezes.

FACULDADE DE DIREITO DA UNIVERSIDADE DE SÃO PAULO São Paulo 


\title{
TRIBUNAIS INTERNACIONAIS E O PODER JUDICIÁRIO BRASILEIRO
}

\author{
elaborada por \\ VITOR GEROMEL \\ como requisito parcial para a obtenção do grau de \\ MESTRE EM DIREITO INTERNACIONAL
}

BANCA EXAMINADORA:

Prof. Associado. Wagner Menezes, Orientador (FDUSP) 


\section{AGRADECIMENTOS}

À minha família, pelo amor e apoio incondicional, sem os quais a realização deste Mestrado não seria possível.

Ao meu orientador, Professor Associado Wagner Menezes, por ter sido, além de um grande mestre, um grande amigo e incentivador.

Aos meus amigos e colegas da Faculdade de Direito da USP, pelo apoio, troca de ideias e momentos de descontração tão necessários à realização deste estudo.

Aos professores do Departamento de Direito Internacional e Comparado, em especial aos professores Paulo Borba Casella e André de Carvalho Ramos, pelas lições, inspiração e exemplo de acadêmicos sérios e comprometidos.

À Claudia e Fernanda, pelos incontáveis "galhos quebrados" e pela atenção sempre presente.

Aos servidores das Bibliotecas da FDUSP - Jéssica, Bruno, Lucas e Helena -, pela preciosa ajuda nas pesquisas e pelas conversas animadas nas horas de descanso.

Ao Fundo Sasakawa de Bolsas para Jovens Líderes, ao qual agradeço em nome do professor Pedro Dallari e do Wilton Cesar Odorico de Oliveira, pelo fundamental apoio no último ano desta empreitada. 
Para Beatriz. 
“O poder corresponde à habilidade humana não apenas para agir, mas também para agir em concerto. O poder nunca é propriedade de um indivíduo; pertence a um grupo e permanece em existência apenas enquanto o grupo se conserva unido". 


\section{RESUMO}

Esta dissertação tem por objetivo analisar a relação dos tribunais internacionais com o Poder Judiciário brasileiro. O estudo demonstra como o Direito Internacional evoluiu na solução pacífica de controvérsias até sua jurisdicionalização e como esse processo deu origem aos tribunais internacionais. Delimita, também, o conceito de tribunais internacionais e discorre sobre questões que envolvem a jurisdição internacional, a jurisprudência e a relação com os direitos internos. Aponta, ainda, as decisões judiciais internacionais que surtem efeitos externos e devem ser observadas e executadas pelos Estados. Ademais, demonstra a importância dos judiciários internos para a plena efetivação dessas decisões e descreve os mecanismos de comunicação utilizados para isso. Por fim, discute a atuação do Poder Judiciário brasileiro quando em face de decisões judiciais internacionais, observando a aplicação desses mecanismos de comunicação.

Palavras-chave: Tribunais internacionais. Poder Judiciário brasileiro. Relações. Comunicação. 


\begin{abstract}
The present dissertation aims to analyze the relations between international courts and the Brazilian Judiciary Power. It shows how international law evolved on peaceful settlement of disputes to its jurisdictionalisation and how this process gave origin to international courts. It delimits the concept of international courts and treats questions about international jurisdiction, international jurisprudence and the relation with municipal laws. It points out which international judicial decisions emanate external effects and ought to be enforced and executed by the States. It shows the importance of domestic judiciaries to the plain effectiveness of those decisions and describes the mechanisms of communication applied for it. Finally, it discusses the role of Brazilian Judiciary Power when dealing with international judicial decisions observing the application of the mentioned mechanisms of communication.
\end{abstract}

Key words: International courts. Brazilian Judiciary Power. Relations. Communication. 


\section{LISTA DE SIGLAS}

$\begin{array}{lll}\text { ADCT } & - & \text { Ato de Disposições Constitucionais Transitórias } \\ \text { ADPF } & - & \text { Arguição de Descumprimento de Preceito Fundamental } \\ \text { CADH } & - & \text { Convenção Americana de Direitos Humanos } \\ \text { CCJ } & - & \text { Corte Centroamericana de Justiça } \\ \text { CDI } & - & \text { Comissão de Direito Internacional } \\ \text { CF/88 } & - & \text { Constituição da República Federativa do Brasil de 1988 } \\ \text { CIJ } & - & \text { Corte Internacional de Justiça } \\ \text { CPA } & - & \text { Corte Permanente de Arbitragem } \\ \text { CPJI } & - & \text { Corte Permanente de Justiça Internacional } \\ \text { CVDT } & - & \text { Convenção de Viena sobre o Direito dos Tratados de 1969 } \\ \text { DIP } & - & \text { Direito Internacional Público } \\ \text { ER } & - & \text { Emenda Regimental } \\ \text { ITLOS } & - & \text { Tribunal Internacional para o Direito do Mar } \\ \text { Mercosul } & - & \text { Mercado Comum do Sul } \\ \text { MPF } & - & \text { Ministério Público Federal } \\ \text { OIs } & - & \text { Organizações Internacionais } \\ \text { OIT } & - & \text { Organização Internacional do Trabalho } \\ \text { OMC } & - & \text { Organização Mundial do Comércio } \\ \text { ONG } & - & \text { Organização Não Governamental } \\ \text { ONU } & - & \text { Organização das Nações Unidas } \\ \text { STF } & - & \text { Supremo Tribunal Federal } \\ \text { STJ } & - & \text { Superior Tribunal de Justiça } \\ \text { TJUE } & - & \text { Tribunal de Justiça da União Europeia } \\ \text { TPI } & - & \text { Tribunal Penal Internacional } \\ \text { TPR } & - & \text { Tribunal Permanente de Revisão do Mercosul } \\ & & \end{array}$




\section{SUMÁRIO}

INTRODUÇÃO.

\section{A JURISDICIONALIZAÇÃO DO DIREITO INTERNACIONAL:} HISTÓRICO E CONCEITOS.

1.1 HISTÓRICO E DESENVOLVIMENTO DA JURISDICIONALIZAÇÃO DO

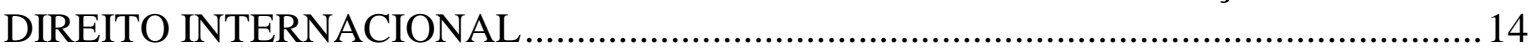

1.1.1 Controvérsias internacionais: conceitos e debates................................................. 14

1.1.2 A construção histórica do princípio da solução pacífica das controvérsias

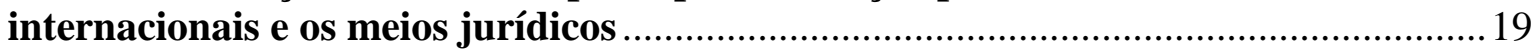

1.1.3 Processo histórico da jurisdicionalização do direito internacional ........................26

1.2 JURISDIÇÕES INTERNACIONAIS, TRIBUNAIS INTERNACIONAIS E A

JURISPRUDÊNCIA INTERNACIONAL: ANÁLISE CONCEITUAL À LUZ DO

DIREITO INTERNACIONAL CONTEMPORÂNEO ………………………………........

1.2.1 Conceito de Tribunais Internacionais ................................................................. 30

1.2.2 Jurisdição Internacional: conceito e principais questões .......................................34

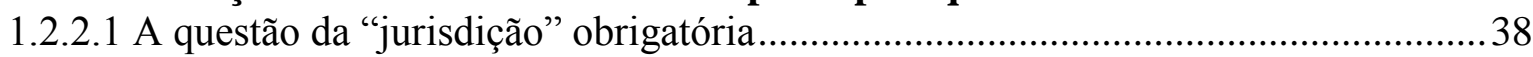

1.2.2.2 Multiplicação de Jurisdições Internacionais: fragmentação ou pluralismo? .............43

1.2.3 A jurisprudência internacional e o direito internacional contemporâneo ……....51

1.3 A RELAÇÃO ENTRE OS DIREITOS INTERNO E O DIREITO INTERNACIONAL

CONTEMPORÂNEO E OS REFLEXOS DA JURISDICIONALIZAÇÃO ..........................55

2 DECISÕES JUDICIAIS INTERNACIONAIS: CONCEITOS, EFEITOS E EXECUÇÃO.

2.1 INTRODUÇÃO E CONCEITO GERAL DE DECISÕES JUDICIAIS INTER-

NACIONAIS

2.2 DECISÕES JUDICIAIS INTERNACIONAIS ........................................................

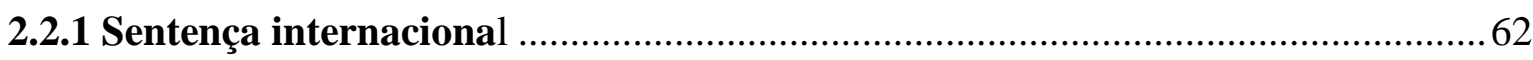

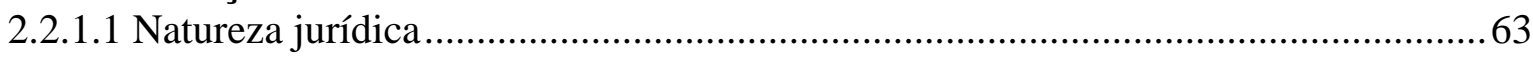

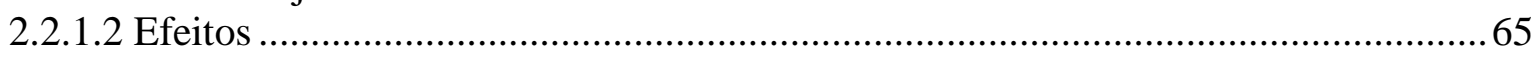

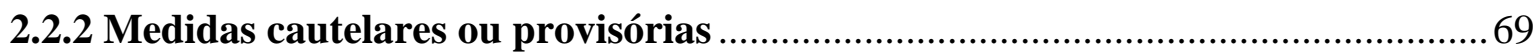

2.2.2.1 Natureza jurídica ........................................................................................... 71

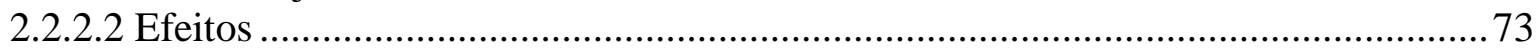

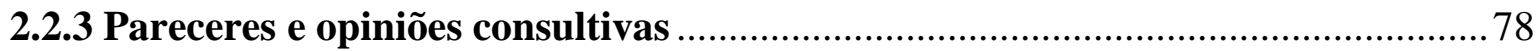

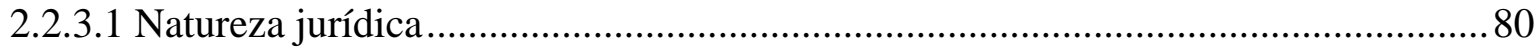

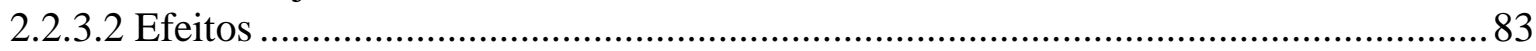

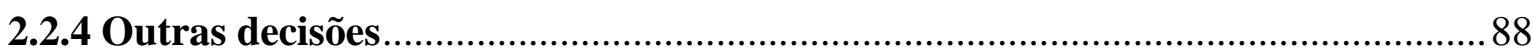

2.2.4.1 Mandado de Prisão e entrega do Tribunal Penal Internacional e outros

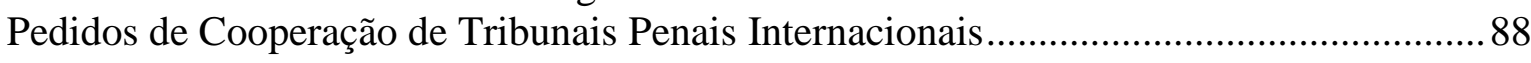

2.2.4.2 Pronta Libertação de Embarcações e Tripulações do Tribunal Internacional

para o Direito do Mar................................................................................................ 90

2.3 OBSERVÂNCIA E EXECUÇÃO DAS DECISÕES JUDICIAIS INTER-

NACIONAIS: RULE OF LAW NA ERA DOS TRIBUNAIS

3 TRIBUNAIS INTERNACIONAIS E O PODER JUDICIÁRIO BRASILEIRO ...101

3.1 PODERES JUDICIÁRIOS E O DIREITO INTERNACIONAL ……………………....101

3.1.1 Poderes Judiciários dos Estados e o Direito Internacional:

breves considerações 
3.1.2 Tribunais Internos e Tribunais Internacionais: entre harmonia e dissonância

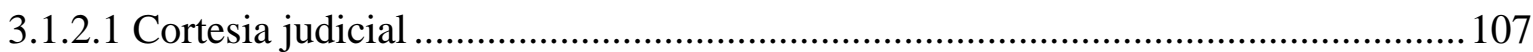

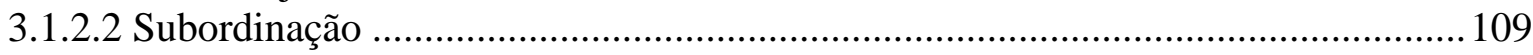

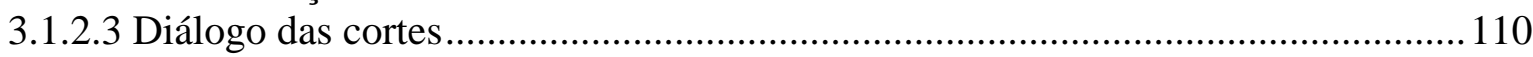

3.1.2.4 Cooperação Jurídica Internacional Vertical ......................................................... 113

3.2 TRIBUNAIS INTERNACIONAIS E O PODER JUDICIÁRIO BRASILEIRO .........115

3.2.1 Ordem Jurídica Brasileira e o Direito Internacional: análise sob a luz da Constituição Federal de 1988

3.2.1.1 Competências do Poder Judiciário em matéria de Direito Internacional................121

3.2.1.2 Disciplina constitucional da hierarquia das normas de Direito Internacional ....... 125

3.2.1.3 Tensões entre Supremacia da Constituição e Prevalência do Direito

Internacional

3.2.1.4 Tribunais Internacionais na Constituição Federal de 1988

3.2.2 Reflexões sobre a observância e a execução de decisões judiciais internacionais pelo Poder Judiciário Brasileiro: aplicação dos mecanismos de comunicação e sua eficácia

3.2.2.1 Considerações preliminares

3.2.2.2 Opiniões consultivas da Corte Interamericana de Direitos Humanos e o

Supremo Tribunal Federal: Extradição 954 e Recurso Extraordinário 511.961

3.2.2.3 Caso dos pneus usados: ADPF 101, Laudo do Tribunal Arbitral ad hoc do Mercosul e Relatório do Órgão de Apelações do Sistema de Solução de Controvérsias da OMC

3.2.2.4 Cooperação com o Tribunal Penal Internacional: Petição 4625/República do Sudão

3.2.2.5 Lei de Anistia e Crimes da Ditadura Militar: ADPF 153 e Caso Gomes

Lund e outros ("Guerrilha do Araguaia")

3.2.2.6 Opiniões Consultivas do Tribunal Permanente de Revisão do Mercosul

e a Emenda Regimental $n^{\circ}$ 48, de 3 de abril de 2012, do STF: aproximação

institucional como um caminho para o diálogo e a cooperação

CONCLUSÃO 


\section{INTRODUÇÃO}

Conflitos são inerentes a qualquer meio social. O Direito também. Nos sistemas jurídicos internos a centralização da jurisdição e do poder de polícia nas mãos do Estado possibilitou a edificação de um Poder Judiciário estruturado competente para resolver, definitivamente, as contendas entre os indivíduos, evitando a autotutela. No sistema internacional, porém, essa evolução foi consideravelmente mais lenta e obstaculizada, contudo, o Direito Internacional chegou melhor institucionalizado e autocompreendido à contemporaneidade. Essa combinação propulsionou seu processo de jurisdicionalização, o que deu origem aos tribunais internacionais, órgãos dotados de jurisdição e competentes para resolver definitivamente as lides e promover o desenvolvimento do Direito Internacional Público (DIP).

Esses tribunais resolvem as controvérsias que lhe são submetidas por intermédio de decisões judiciais internacionais que surtem efeitos tanto internos quanto externos. Essas últimas são quase sempre vinculantes ou detentoras de uma autoridade que fazem valer seus preceitos e demandam ações concretas dos Estados para sua plena observância e execução. Para tanto, muitas vezes, tem que surtir efeitos nas ordens internas, o que delega aos Poderes Judiciários estatais um papel fundamental no resguardo do rule of Law internacional, promovendo o cumprimento das decisões internacionais junto às instituições internas e, em última análise, sua efetividade.

Nas últimas décadas, mais de quatro dezenas de tribunais internacionais foram criados. Esses tribunais possuem configurações diversas, abarcam diferentes temas (especializados ou gerais) e exercem suas competências em espaços geográficos diversos (universais ou regionais). Todos têm, entretanto, uma mesma função, diretamente derivada da jurisdição a eles conferida pelos sujeitos de DIP, que é a resolução pacífica e final das controvérsias e o desenvolvimento do Direito Internacional.

Nesse contexto, o Brasil aderiu a cinco desses tribunais, somando sete com os outros dois dos quais já era parte. Hoje, o Estado brasileiro se encontra sob a jurisdição da Corte Internacional de Justiça, da Corte Permanente de Arbitragem, da Corte Interamericana de Direitos Humanos, do Tribunal Internacional para o Direito do Mar, do Órgão de Apelações do Sistema de Solução de Controvérsias da OMC, do Tribunal Penal Internacional, do Tribunal Permanente de Revisão do Mercosul e, ainda que de maneira indireta, dos tribunais penais ad hoc das Nações Unidas. 
Diante desse quadro, surgem algumas inquietações, como: como se deu essa evolução no Direito Internacional, da autotutela da guerra ao estabelecimento de tribunais internacionais? O que legitima a atuação desses tribunais? Qual o reflexo normativo dessa evolução no Direito Internacional Contemporâneo? Como isso reflete na relação com os direitos internos? Como se dá a observância e a execução das decisões judiciais internacionais e quais mecanismos foram estabelecidos para que sua efetividade fosse garantida? Como os Poderes Judiciários nacionais devem se comunicar com seus pares internacionais? Como o Poder Judiciário brasileiro, especialmente o Supremo Tribunal Federal, vem realizando essa missão?

O presente estudo foi realizado numa perspectiva idealista do Direito Internacional, sob a qual a realidade dos fatos é vista de maneira inconformada e instigadora da busca por melhoramentos. A metodologia utilizada na sua elaboração seguiu os métodos histórico e dedutivo. O estudo da evolução histórica da sociedade internacional até a consagração dos meios pacíficos de solução de controvérsias e da jurisdicionalização do Direito Internacional é fundamental para compreensão dos elementos técnico-jurídicos que serão analisados no desenvolvimento da pesquisa. A investigação, então, se baseia na revisão bibliográfica sobre a temática, no estudo de casos concretos e na análise da legislação, tanto interna, quanto internacional aplicável.

O primeiro capítulo se destina à compreensão da jurisdicionalização do Direito Internacional. Para tal será demonstrada a construção histórica do princípio da solução pacífica de controvérsias até sua concretização na figura dos tribunais internacionais. Após, será investigado o conceito que define essas instituições, bem como as questões relativas à jurisdição internacional, como seu caráter obrigatório e sua multiplicação nas últimas décadas. Outro tema a ser discutido é a influência da jurisprudência internacional como fonte do DIP contemporâneo. Por fim, será lançado um olhar à relação dessa nova ordem internacional com os direitos internos.

No segundo capítulo a atenção estará toda voltada às decisões judiciais internacionais. Para tanto, identificou-se um conceito e, a partir dele, discriminadas as decisões a serem analisadas, quais sejam: sentença, medidas cautelares, opiniões consultivas, pronta libertação de navios e tripulações e os pedidos cooperacionais do TPI. Cada uma dessas terá abordada a sua natureza jurídica e os seus efeitos, a fim de se esclarecer seu alcance, função e importância no contexto dos tribunais internacionais. Após, o trabalho analisará a questão da observância e execução dessas decisões como um importante componente do Império do Direito (rule of Law) na ordem internacional. 
O terceiro capítulo abordará a temática central do estudo. Primeiro, discorrerá sobre os Poderes Judiciários dos Estados no Direito Internacional de forma geral, depois especificamente sobre as relações entre tribunais internos e internacionais, onde foram escolhidos quatro mecanismos de comunicação como meios de promover uma interação harmônica dessas instituições. Posteriormente, será estudada a questão dos tribunais internacionais e o Poder Judiciário brasileiro especificamente, primeiro mostrando como a ordem jurídica brasileira inaugurada pela Constituição Federal de 1988 permite a interação com a ordem jurídica internacional e, depois, analisando de maneira concreta como está se dando a comunicação entre os órgãos judiciais internos e internacionais, com especial foco à jurisprudência do Supremo Tribunal Federal.

Este estudo tem por objetivo demonstrar como a evolução do Direito Internacional na solução pacífica de controvérsias desenvolveu os tribunais internacionais e como esses, por intermédio das decisões judiciais internacionais, reforçam o império do Direito na comunidade internacional. A partir dessa premissa, o estudo visa mostrar que a atuação dos tribunais internos na efetivação dessas decisões é essencial para o cumprimento dessa missão. Apresenta, também, a forma como o Poder Judiciário brasileiro vem atuando nesse sentido. 


\section{A JURISDICIONALIZAÇÃO DO DIREITO INTERNACIONAL: HISTÓRICO E CONCEITOS}

\subsection{HISTÓRICO E DESENVOLVIMENTO DA JURISDICIONALIZAÇÃO DO DIREITO INTERNACIONAL}

\subsubsection{Controvérsias internacionais: conceitos e debates}

Os conflitos são inerentes à vida em sociedade, seja essa nacional ou internacional. Do mesmo modo, o Direito é inerente à sociedade, como ratifica a máxima latina ubis societas ibi jus. O Direito possui uma função ordenadora na vida social, organizando-a e compondo seus eventuais litígios ${ }^{1}$. O Direito Internacional não é diferente. O sistema jurídico internacional em sua evolução construiu seu arcabouço normativo diretamente voltado para solução de suas controvérsias, seja por meios coercitivos ou pacíficos.

$\mathrm{Na}$ presente dissertação, em razão do tema, será analisado somente o desenvolvimento dos meios pacíficos no Direito Internacional, contudo, antes disso, será feita uma investigação do conceito de "controvérsia internacional"2. A importância de uma análise detalhada desse conceito advém do fato de que a existência de uma controvérsia internacional é uma condição primária para o exercício da função jurisdicional internacional ${ }^{3}$.

Correntemente utilizado pela doutrina e jurisprudência, o conceito elaborado pela extinta Corte Permanente de Justiça Internacional (CPJI), no caso Mavrommatis, define, de forma aberta, os contornos de uma controvérsia internacional. Segundo o órgão jurisdicional, trata-se de "um desacordo sobre um ponto de direito ou de fato, uma contradição, uma oposição de teses jurídicas ou de interesse entre duas pessoas" ". Coube à esfera doutrinária a delimitação de tal conceito, como será demonstrado adiante.

CASELLA, na atualização do Manual de Direito Internacional Público, obra publicada em conjunto com ACCIOLY e NASCIMENTO E SILVA, afirma que os

\footnotetext{
${ }^{1}$ CINTRA, Antonio Carlos de Araujo; GRINOVER, Ada Pellegrini; DINAMARCO, Cândido Rangel. Teoria geral do processo. 23. ed. São Paulo: Malheiros, 2007. p. 25.

${ }^{2}$ No âmbito do presente estudo, as palavras "conflito", "litígio", "disputa" e "controvérsia" serão utilizadas como sinônimos.

${ }^{3}$ INTERNATIONAL COURT OF JUSTICE. Nuclear tests case (Australia vs. France). Judgment of 20 December 1974. Reports of Judgments, Advisory Opinions and Orders, 1974, pp. 270-1.

4 "Un différend est un désaccord sur un point de droit ou de fait, une contradiction, une opposition de thèses juridiques ou d'intérêts entre deux personnes." (COUR PERMANENTE DE JUSTICE INTERnAtionale. Affaire des Concessions Mavrommatis en Palestine. Series A-n ${ }^{\circ} 20$. Audiénce du 30 Août 1924. Recueil des Arrêts. Leyde: Société D’éditions A. W. Sijthoff, 1924. p. 11).
} 
Estados, assim como os homens, estão sujeitos a paixões e choques de interesse de maior ou menor gravidade. Esses impasses resultam nas controvérsias internacionais, que podem ter as mais variadas causas. Contudo, é de interesse comum da sociedade internacional que essas contendas sejam resolvidas de maneira menos traumática possível ${ }^{5}$.

Para REUTER, o estudo sociológico dos conflitos é um dos campos mais amplos da sociologia geral, o que impõe uma série de obstáculos para sua transposição às relações internacionais $^{6}$. $\mathrm{O}$ ponto de partida de sua análise sobre o tema foi examinar suas causas, objetivos, atores e instrumentos para depois deter-se no estudo dos meios para solucionálos.

Já AMARAL JÚNIOR defende a tese de que as controvérsias internacionais são desacordos oriundos da "faculdade de autointerpretação" dos Estados que, em se utilizando dessa, acabam por formular uma pretensa relação a um objeto e, assim, afetar o interesse de outros que, por sua vez, poderão reagir de diversos modos ${ }^{7}$. Nesse mesmo sentido, o autor ensina que elas podem surgir em duas circunstâncias, isto é, quando há uma contenda em relação ao significado de uma norma internacional existente, ou quando houver divergência na qualificação dos fatos que motive a criação de uma nova regra ${ }^{8}$.

VISSCHER, em sua obra Théories et réalités en droit international public, elaborou um conceito de controvérsias internacionais e estabeleceu uma diferenciação com as tensões políticas. Tidas como fenômenos essencialmente políticos, as tensões políticas, por sua natureza, não se sujeitam a meios de solução pacífica de controvérsias. Em última instância, ligam-se a transformações nas relações de poder ${ }^{9}$. Já as controvérsias internacionais são desentendimentos entre Estados sobre um objeto "suficientemente circunscrito para se prestar a pretensões claras e suscetíveis de um exame racional"10. Possuem variações de acordo com o grau de envolvimento político, o que também definirá, de acordo com o autor, o meio mais adequado para sua solução ${ }^{11}$.

\footnotetext{
${ }^{5}$ ACCIOLY, Hildebrando; NASCIMENTO E SILVA, G. E.; CASELLA, Paulo Borba. Manual de Direito Internacional Público. 17. ed. São Paulo: Saraiva, 2009. pp. 755-60, passim.

${ }^{6}$ REUTER, Paul. Droit international public. Paris: Presses Universitaires de France, 1993. p. 359.

7 AMARAL JÚNIOR, Alberto do. Curso de direito internacional público. 2. ed. São Paulo: Atlas, 2011. p. 258.

${ }^{8}$ Id., ibid., p. 259.

${ }^{9}$ VISSCHER, Charles de. Théories et réalités em droit international public. 4. ed. Revue et mise à jour. Paris: Pedone, 1970. p. 371.

10 "On a vu que le différend internaitonal est un désaccord entre Etats relativement à un objet suffisamment circonscrit pour se prêter à des prétentions claires, susceptibles d'un examen rationel." (Id., ibid., 1970, p. 371).

${ }^{11}$ Id., ibid., p. 371.
} 
Outra importante discussão, diz respeito à classificação das controvérsias como políticas ou jurídicas ${ }^{12}$. A distinção clássica entre ambas é que as primeiras (políticas) não estão sujeitas à jurisdição internacional, seja essa arbitral ou de um órgão jurisdicional permanente, enquanto as outras (jurídicas) distinguem as adjudicáveis das não adjudicáveis. Dessa maneira, a elaboração dessa problemática serviu de verdadeira limitação à atuação da jurisdicional internacional desde as suas origens ${ }^{13}$.

No ano de 1933, em curso proferido na Academia da Haia intitulado La Théorie des Différends non Justiciables en Droit International, LAUTERPACHT associou essa questão à teoria da soberania. $\mathrm{O}$ autor defende a tese de que juristas e homens de Estado valeram-se dos postulados dessa teoria para legitimar a reivindicação estatal do direito de ser seu próprio juiz quando em uma contenda com seus pares. Assim, nasceu a teoria das controvérsias não adjudicáveis ou não jurídicas ${ }^{14}$. Vale ressaltar que o autor supracitado foi um dos seus maiores críticos, colocando o debate no âmbito da chamada teoria das limitações do processo judicial no Direito Internacional ${ }^{15}$.

Cinco anos antes, em 1928, na mesma Academia de Direito Internacional, SCHINDLER, no decorrer de sua análise do progresso da arbitragem obrigatória no âmbito da Sociedade das Nações ${ }^{16}$, também enfrentou essas inquietações. Ao tratar da extensão do objeto de seu estudo, o autor desenvolveu um ensaio sobre a teoria dos conflitos internacionais e tratou detidamente da problemática aqui discutida ${ }^{17}$, estabelecendo

\footnotetext{
12 “Le problème des diffèrends dits 'politiques' ou 'non juridiques' pose une série de questions complexes et en définitive celle du concept de 'droit'. Ces différends sont caractérisés par le fait que, dans les actes de droit international où leur non-justiciabilité est prévue, il n'est, le plus souvent, pas fourni de critère pour leur détermination et que, dans le cas pratiques, celle-ci n'appartient en général pas a une autorité supérieure aux Etats, mais aux Etats eux-mêmes. Lorsqu'un critère est fourni, comme en matière de compétence exclusive, il fait l'objet des commentaires les plus variés et contradictoires possibles." (VAUCHER, Marius. Le problème de la justiciabilité et de la non-justiciabilité en droit international des différend dits "politiques" ou "non-juridiques" et les notions de compétence exclusive et de compétence nationale (Article 15, § 8 du Pacte de la S.d.N. et article 2, $§ 7$ de la Charte de l’ONU.) Paris: Pedone, 1951. p. XII).

13 "En principe, tous les différends nés entre sujets de droit international sont susceptibles d'être tranchés par un organe judiciaire. Toutefois, dès les origines de la juridiction arbitrale et judiciaire contemporaine, on a vu se développer, aussi bien dans la doctrine que dans la pratique internationale, une tendance vers la limitation de la justiciabilité des conflicts, celles-ci étant réservée à certains différends déterminés." (GUGGENHEIM, Paul. Traité de droit international public. Tome II. Genève: Librairie de l'Université, Georg \& Cie S. A., 1954. p. 106).

${ }^{14}$ LAUTERPACHT, H. La théorie des différends non justiciables en droit international. RCADI, v. 34, 1930, IV, pp. 493-654. p. 500.

${ }^{15}$ LAUTERPACHT, $\mathrm{H}$. The function of law in the international community. Oxford: Claredon Press, 1933. pp. 3-69, passim.

${ }^{16}$ SCHINDLER, Diètrich. Les progrès de l'arbitrage obligatoire. Depuis la Création de la Société des Nations. RCADI, v. 25, 1928-V, pp. 233-364.

17 "La plus grande partie des traités d'arbitrage obligatoire ne soumettent pas tous les conflits à la sentence du juge ou de l'arbitre. Ils font une distinction entre les litiges d'ordre juridique et les litiges d'ordre non juridique, et ne soumettent à l'arbitrage que les premier." (SCHINDLER, Diètrich. Les Progrès de
} 
diferenças conceituais entre os dois tipos de controvérsias. As políticas seriam aquelas oriundas de conflitos de ordem legislativa ou executiva - poderes ausentes na sociedade internacional - e as judiciais seriam as oriundas de conflitos de ordem judiciária ${ }^{18}$.

No Pacto da Sociedade das Nações realizou-se uma tentativa de definir de forma exata as "controvérsias jurídicas". Mediante proposta do delegado dos Estados Unidos, Elihu Root, foram enumeradas no art. 13, alínea 2 do referido Pacto, algumas dessas situações $^{19}$. O Estatuto da CPJI, por sua vez, em seu art. 36, também procurou definir critérios para identificação dos conflitos que cairiam na jurisdição da recém-criada Corte Internacional. E o fez de forma ampla, ao prever que as partes poderiam submeter à sua apreciação "todos os casos e matérias"20.

O Instituto de Direito Internacional, em resolução adotada na Sessão de Grenoble, em 1922, reportada por Philip Marshal BROWN e Nicolas POLITIS, procurou estabelecer critérios para caracterização da controvérsia jurídica no caso concreto, tendo em vista a redação ampla do art. 36 do Estatuto da CPJI. No art. $1^{\circ}$ ficou estabelecido que, em primeira análise, qualquer conflito é susceptível de adjudicação ou solução arbitral, independentemente de sua classificação. No art. $2^{\circ}$, entretanto, recomendou-se que no caso do Estado citado não concordar com a justiciabilidade do conflito, caberá à CPJI, em fase preliminar, decidir se o é ou não, prosseguindo com o procedimento ordinário em caso positivo. Em caso negativo, a contenda é devolvida às partes para utilização de outro meio de solução pacífica ${ }^{21}$.

Em obra publicada no ano de 1944, KELSEN procura encerrar a discussão de maneira lógica. Na primeira parte de A paz pelo direito, o jurista austríaco propõe a criação de um tribunal internacional com jurisdição obrigatória para julgar todo e qualquer conflito entre os povos, considerado o verdadeiro guardião da paz internacional. Sobre a problemática discutida nos últimos parágrafos, Kelsen conclui:

L'Arbitrage Obligatoire. Depuis la Création de la Société Nations. RCADI, t. 25, 1928-V. pp. 233-364, p. 264).

${ }^{18}$ Ib., ibid., p. 269.

19 "Parmi ceux qui sont généralement susceptibles de solution arbitrale, on déclare tels les différends relatifs à l'interpretation d'un Traité, a tout point de droit international, a la realité de tout fait qui, s'il était établi, constituerait la rupture d'un engagément international, ou à l'étendue ou a la nature de la réparation due pour une telle rupture." (PACTE DE LA SOCIETE DES NATIONS. Art. 13, 2).

20 "The jurisdiction of the Court comprises all cases which the parties refer to it and all matters specially provided for in treaties and conventions in force." (STATUE OF THE PERMANENT COURT OF INTERNATIONAL JUSTICE, art. 36).

${ }^{21}$ INSTITUT DE DROIT INTERNATIONAL. Classification des conflits justiciables. Rapporteurs: MM. Philip Marshal Brown et Nicolas Politis. Session de Grenoble, 1922. 
O sistema normativo da ordem jurídica internacional é aplicável em ambos os casos e, consequentemente, tanto os conflitos políticos quanto os jurídicos são passíveis de apreciação judiciária no sentido legítimo do termo, o que indica que podem ser resolvidos por uma decisão judicial que aplica o direito positivo ao conflito $^{22}$.

Resta saber se a discussão sobre o caráter das controvérsias subsiste no Direito Internacional Contemporâneo, tendo em vista a considerável, e ainda constante mudança de estruturas ${ }^{23}$ e paradigmas ${ }^{24}$ e o crescente aumento dos espaços de jurisdição. A resposta mais adequada em se analisando a doutrina e a jurisprudência velaria pela extinção dessa classificação.

Embora o Estatuto da Corte Internacional de Justiça em seu art. 36 (2) use o termo "controvérsias de ordem jurídica" como requisito para atuação da Jurisdição, em vários casos já foram decididas questões tradicionalmente tidas como políticas ${ }^{25}$. A mera alegação de que uma controvérsia seja de caráter político é vista como um artifício fora de moda para afastar a jurisdição diante da qual a questão foi apresentada ${ }^{26}$.

Ademais, temas que antigamente estavam sob o domínio exclusivo dos Estados logo, questões tidas de natureza claramente política - como, por exemplo, os Direitos Humanos ${ }^{27}$ e a gestão de recursos ambientais ${ }^{28}$, são agora temas de legítimo interesse jurídico internacional e, geralmente, sua normatização global vem acompanhada de órgãos mundiais de monitoramento com natureza judicial ou quasi judicial ${ }^{29}$.

\footnotetext{
${ }^{22}$ KELSEN, Hans. A paz pelo direito. São Paulo: WMF Martins Fontes, 2011. p. 28.

${ }^{23}$ Ver FRIEDMANN, Wolfgang. The changing structures of International Law. New York: Columbia University Press, 1964.

${ }^{24}$ Ver CASELLA, Paulo Borba. Fundamentos do Direito Internacional pós-moderno. São Paulo: Quartier Latin, 2008.

${ }^{25}$ MENEZES, Wagner. Tribunais Internacionais: jurisdição e competência. São Paulo: Saraiva, 2013. pp. $103-4$.

26 “A determinação do caráter jurídico ou não de qualquer controvérsia, e a recusa em submeter-se o estado à jurisdição da Corte, alegando ser a controvérsia política e não jurídica, como referido, pode ser escusa corrente, invocada pelo Estado que quer se subtrair da apreciação pela Corte Internacional de Justiça do caso a esta apresentado, por outro estado, por razões que a razão desconheça. Mas esta natureza, que política ou jurídica, haverá de ser apreciada e determinada pela Corte, e não pelo estado que invoca tal circunstância!" (ACCIOLY, Hildebrando; NASCIMENTO E SILVA, G. E.; CASELLA, Paulo Borba. Manual de Direito Internacional Público. 17. ed. São Paulo: Saraiva, 2009, p. 762).

27 CANÇADO TRINDADE, Antônio Augusto. Direitos humanos: personalidade e capacidade jurídica internacional do indivíduo. In: BRANT, Leonardo Nemer Caldeira (Coord.). O Brasil e os novos desafios do Direito Internacional. Rio de Janeiro: Forense, 2004. pp. 199-263. p. 206; CANÇADO TRINDADE, Antônio Augusto. International law for humankind: towards a new Jus Gentium (I). General Course on Public International Law. RCADI, 2005, v. 316. pp. 1-439. p. 259.

${ }^{28}$ SOARES, Guido Fernandes Silva. Direito Internacional do meio ambiente: emergência, obrigações e responsabilidades. São Paulo: Atlas, 2001; SOARES, Guido Fernandes Silva. A proteção internacional do meio ambiente. Barueri: Manole, 2003.

${ }^{29}$ RAMOS, André de Carvalho. Processo Internacional de direitos humanos. Análise dos sistemas de apuração de violações de direitos humanos e a implementação das decisões no Brasil. São Paulo: Saraiva, 2012; PIOVESAN, Flávia. Direitos humanos e Direito Constitucional Internacional. 7. ed. rev., ampliada
} 
Conclui-se, então, que a distinção entre controvérsias políticas e jurídicas não subsiste ao Direito Internacional Contemporâneo. Feita a análise sobre o conceito e problemáticas relativas às controvérsias internacionais, a preocupação agora é avançar no sentido da investigação dos meios pacíficos para sua solução.

\subsubsection{A construção histórica do princípio da solução pacífica das controvérsias internacionais e os meios jurídicos}

Nos sistemas jurídicos internos, o desenvolvimento do Estado Moderno levou à centralização e verticalização do poder e à consequente viabilidade da estruturação de um Judiciário dotado de jurisdição sobre os conflitos que lhe eram apresentados. Nesse cenário, o Estado é o único legitimado a resolver definitivamente esses conflitos, afastando a prática da autotutela entre os particulares.

No âmbito internacional, porém, os paradigmas são diferentes, sendo a descentralização do poder ${ }^{30}$ e a dita anarquia características da sociedade internacional clássica. Não há, portanto, qualquer instituição acima dos seus sujeitos que pode assegurarlhes a observância do Direito Internacional ${ }^{31}$. Assim, diante de um conflito internacional, tal cenário favoreceu a prática da autotutela entre os Estados, constituindo-se na causa de sérios traumas na História. Para prevenir essas situações, a evolução do Direito Internacional proporcionou o desenvolvimento de mecanismos pacíficos de solução de controvérsias. Tais mecanismos se amoldaram e se desenvolveram de acordo com a evolução da própria sociedade internacional ${ }^{32}$ até chegar ao formato contemporaneamente conhecido dos órgãos judiciais internacionais.

Desde a Antiguidade, a solução pacífica de controvérsias entre os povos tem sido objeto de preocupação política e doutrinária. Embora o império da força tenha sido a tônica nas embrionárias relações internacionais da época, a história do Direito Internacional mostra os esforços dos povos antigos no sentido da criação de institutos que resolvam seus

e atualizada. São Paulo: Saraiva, 2006; PIOVESAN, Flávia. Direitos humanos e Justiça Internacional. Um estudo comparativo dos sistemas regionais europeu, interamericano e africano. São Paulo: Saraiva, 2006.

${ }^{30}$ TRUYOL Y SERA, Antonio. Genèse et structure de la société internationale. RCADI, 1959-I, v. 96. pp. 553-642. pp. 570-2, passim.

31 "Au degré de développement auquel l'humanité est parvenue de nos jours, la plus haute expression de la souveraineté réside dans l'État. Ni en dehors, au-dessus de lui, il n'y a de puissance capable d'edicter des lois et de faire régner le droit.[...]." (NYS, Ernest. Les origines du Droit International. Bruxelles: Alfred Castaigne, 1894. p. 49).

32 "A natureza do direito internacional é forçosamente determinada pela natureza da sociedade em que actua.” (BRIERLY, J. L. Direito Internacional. Trad. de M. R. Crucho de Almeida. 4. ed. Lisba: Fundação Calouste Gulbenkian, 1979. p. 41). 
conflitos de maneira pacífica, promovendo negociações, mediações e até mesmo procedimentos arbitrais ${ }^{33}$.

Na Idade Média, a Igreja Católica exercia o poder central na Europa, o direito canônico possuía status superior ${ }^{34}$ e o poder do Papa, somado ao feudalismo, dificultava a formação de autoridades centrais fortes nos territórios ${ }^{35}$. Nesse período histórico, as controvérsias internacionais eram quase sempre solucionadas por guerras, o que passou a preocupar a Igreja e seus pensadores ${ }^{36}$. De Francisco SUAREZ a Hugo GROTIUS, os fundadores da disciplina Direito Internacional direcionaram suas reflexões sobre a sociedade internacional, usando como base a questão dos conflitos armados, o que levou à formulação de várias teorias a respeito da guerra ${ }^{37}$.

$\mathrm{Na}$ modernidade, o enfraquecimento do poder da Igreja deu lugar à forma denominada clássica da sociedade internacional e do Estado, ambos lastreados na doutrina da soberania. BRIERLY afirma que uma "curiosa metamorfose", promovida no seio dos Estados modernos, distorceu o conceito de soberania inicialmente proposto por Jean Bodin, transportando-o inadequadamente para o plano externo e o erigindo como um verdadeiro "princípio de anarquia internacional",38, dificultando a sujeição daqueles ao Direito Internacional ${ }^{39}$.

${ }^{33}$ TAUBE, Le Baron Michel de. Les origine de L'Arbitrage International. Antiquité et Moyen Age. RCADI, v. 42, 1932-IV, pp. 1-115); BEDERMAN, David J. International Law in Antiquity. Cambridge: Cambridge University Press, 2001. pp. 165-71, passim; GAURIER, Dominique. Histoire du droit international. Auters, doctrines et développement de l'Antiquité à l'auber de la période contemporaine. Rennes Cedex: Presses Universitaires de Rennes, 2005. pp 60-2 ; LAGHMANI, Slim. Histoire du droit des gens: du jus gentium impérial au jus publicum europaeum. Paris: A. Pedone, 2003 ; CASELLA, Paulo Borba. Direito Internacional no Tempo Antigo. São Paulo: Atlas, 2012a; CASELLA, Paulo Borba. Direito Internacional no Tempo Medieval e Moderno até Vitória. São Paulo: Atlas, 2012b.

${ }^{34}$ SHAW, Malcolm. International Law. $6^{\text {th }}$ ed. Cambridge: Cambridge University Press, 2010. p. 19.

35 BRIERLY, J. L. Direito internacional. Trad. de MR. Crucho de Almeida. 4. ed. Lisboa: Fundação Calouste Gulbenkian, 1979, pp. 1-2.

36 "O dilema de tentar regular a guerra marca profundamente o direito internacional. Desde a era medieval, passando aos internacionalistas da era moderna, como Alberico Gentili, sobre o direito da guerra (1958) e Hugo Grócio, sobre o direito da guerra e paz (1625), passando destes internacionalistas modernos aos seus autores clássicos, e - sem solução plena - até os dias atuais." (CASELLA, Paulo Borba. Op. cit., 2012b, p. 263).

${ }^{37}$ Ver VITÓRIA, Francisco de. Os índios e o direito da guerra. Trad. de Ciro Mioranza. Ijuí, RS: Ed. Unijuí, 2006; GENTILI, Alberico. O direito da guerra: de jure belli. Trad. de Ciro Mioranza. Ijuí, RS: Ed. Unijuí, 2006; GROTIUS, Hugo. O direito da guerra e da paz. Trad. de Ciro Mioranza. Florianópolis: Ed. Unijuí-Fondazione Cassamarca, 2004.

38 BRIERLY, J. L. Direito internacional. Trad. de MR. Crucho de Almeida. 4. ed. Lisboa: Fundação Calouste Gulbenkian, 1979. p. 45.

39 "De fato, Bodin fez distinção entre lei e leis, afirmando que o soberano estaria acima de leis particulares do país que ele governa, mas como membro de uma comunidade humana, estaria sujeito à lei divina e natural e às leis das nações, pois mesmo que se definisse a soberania como isenta de todas as leis, não haveria soberano que teria plenitude desses direitos em razão de que a lei divide e a lei natural abrangeria a todos, inclusive o soberano." (MENEZES, Wagner. Tribunais internacionais: jurisdição e competência. São Paulo: Saraiva, 2013, p. 51). 
Assentado nessa ideia distorcida de soberania externa absoluta é que se fundou, a partir da Paz de Westfália, em 1648, o chamado Direito Internacional Clássico, que pode ser caracterizado como um sistema jurídico no qual, em razão do poder soberano, os Estados, seus únicos sujeitos à época, contraiam, ou não, obrigações de acordo com sua própria vontade. Surge daí o voluntarismo estatal, que fundamentou predominantemente as relações jurídicas internacionais por mais de três séculos ${ }^{40}$.

A partir desse quadro, a guerra continuou sendo entendida como um direito soberano dos Estados e os métodos pacíficos de solução de controvérsias se resumiam aos diplomáticos, com exceção de alguns tribunais arbitrais ${ }^{41}$. Esse panorama começou a mudar no contexto panamericano com o Tratado de União da Liga da Confederação Perpétua, de 1826 que, em seu art. 16, propugnava pela solução amigável dos litígios entre as partes ${ }^{42}$. Foi a partir das Conferências de Paz da Haia, no entanto, que as formas pacíficas de entendimento entre os Estados foram sistematizadas e ganharam expressão no ordenamento internacional.

Convocada por iniciativa do czar Nicolau II, em 1899, a Primeira Conferência de Paz da Haia nasceu em um contexto mundial de crescente evolução tecnológica, institucional e bélica, mas também de conscientização humanitária ${ }^{43}$. Aquele cenário levou o monarca russo a incitar as discussões, possivelmente influenciado por pacifistas e, também, em decorrência do perigoso abalo do sistema de equilíbrio de poder instituído na Europa $^{44}$.

GAURIER comenta que uma primeira circular do czar dava como motivo principal para a Conferência a "manutenção da paz geral e a redução de armamentos". Alguns meses depois, em uma segunda circular, o mesmo especificou seus objetivos, que podem se

\footnotetext{
40 "Se se afirma como dependente da vontade do estado a criação do direito, quer interno, quer internacional, priva-se o direito de sua juridicidade. Se o estado somente estiver sujeito à lei que faz (ou em relação à qual manifeste seu consentimento em estar vinculado), a qualquer momento pode desfazer por outra lei, essencialmente não estará o estado sujeito ao direito. O primado do estado soberano, em relação à ordem jurídica - e isto, igualmente considerado, no plano interno, como internacional -, é incompatível com o estado de direito." (CASELLA, Paulo Borba. Fundamentos do Direito Internacional Pós-moderno. São Paulo: Quartier Latin, 2008. p. 758).

${ }^{41}$ Como exemplos do uso da arbitragem na Modernidade do Direito Internacional tem-se o Tratado Jay, de 1794; o Tratado de Paz entre Brasil e Portugal, de 1825; o Tratado de Paz entre o Brasil e o Paraguai, de 1872; a Questão do Alabama entre os Estados Unidos e a Grã-Bretanha, de 1862, entre outros (ACCIOLY, Hildebrando. Tratado de Direito Internacional Público. São Paulo: Quartier Latin, 2009, v. III. pp. 67-94, passim).

${ }^{42}$ MENEZES, Wagner. Derecho Internacional en América Latina. Traducción de Ana Carolina Izaga de Senna Ganem. Brasília: FUNAG, 2010. p. 235.

${ }^{43}$ TRUYOL Y SERA, Antonio. Historia del Derecho Internacional Público. Version española de Paloma García Picazo. Madrid: Tecnos, 1998. p. 112.

${ }^{44}$ GAURIER, Dominique. Histoire du droit international. Auters, doctrines et développement de l'Antiquité à l'auber de la période contemporaine. Rennes Cedex: Presses Universitaires de Rennes, 2005. p. 416
} 
resumir em três pontos principais: 1) a regulamentação das práticas na guerra; 2) sua prevenção por meio de bons ofícios, da mediação e da arbitragem; e 3) a estagnação dos orçamentos militares em tempos de paz e, se possível, sua redução ${ }^{45}$.

Compareceram a essa Primeira Conferência de Paz da Haia um total de 26 Estados. Sua Ata Final foi assinada no dia 29 de julho de 1899 e, como resultado, foram anunciadas três convenções, três declarações e seis votos. As convenções versavam sobre meios pacíficos de solução de controvérsias, desarmamento e regulamentação das leis da guerra. As declarações diziam respeito somente às práticas da guerra, assim como a maioria dos $\operatorname{votos}^{46}$.

Oito anos depois, em 1907, por iniciativa do presidente dos Estados Unidos, instaurou-se a Segunda Conferência de Paz da Haia. Segundo TRUYOL Y SERRA, o principal motivo para a promoção de uma segunda conferência foi a "insuficiência de resultados da primeira"47. De fato, a Conferência de 1907 foi considerada uma continuidade da de 1899, pois foram aperfeiçoados os seus dispositivos em relação à solução pacífica de controvérsias, bem como foram complementadas as disposições da convenção relativas às leis e costumes na guerra ${ }^{48}$.

A importância das duas conferências de paz da Haia para o Direito Internacional Público é inquestionável, contudo, é fundamental ressaltar seu protagonismo, pois foram as primeiras conferências oficiais em que os Estados componentes da sociedade internacional à época se uniram para discussão de estratégias comuns para a paz ${ }^{49}$. Destaca-se, também, que foi a partir delas que surgiram os primeiros contornos da solução pacífica de controvérsias como um princípio, bem como o delineamento dos meios jurídicos, com a criação da Corte Permanente de Arbitragem (CPA), em $1899^{50}$.

Com o advento da Primeira Grande Guerra Mundial, toda essa estrutura construída pelas Conferências de Paz da Haia parecia ter desabado. Não obstante, com o fim do conflito, houve um importante resgate das teorias idealistas do Direito Internacional,

\footnotetext{
${ }^{45}$ Id., ibid., pp. 413-4.

${ }^{46}$ LAGHMANI, Slim. Histoire du droit des gens: du jus gentium imperial au jus publicum europaeum. Paris: Éditions A. Pedone, 2003. p. 170.

${ }^{47}$ TRUYOL Y SERRA, Antonio. História del Derecho Internacional Público. Version española de Paloma García Picazo. Madrid: Tecnos, 1998. p. 113.

${ }^{48}$ GAURIER, Dominique. Op. cit., 2005, pp. 420-1.

${ }^{49}$ WEHBERG, Hans. La contrubution des Conférences de la Paix de la Haye au Progrès du Droit International. RCADI, 1931-III, v. 37. pp. 527-669. p. 534.

${ }^{50}$ ROMANO traz a seguinte crítica: "Though the 1899 creation of the Permanent Court of Arbitration (PCA) is usually hailed as the beginning of modern international dispute settlement, it is not a significant landmark in this narrative because it did not alter the prevailing consensual paradigm." (ROMANO, Cesare P. R. The shift from the consensual to the Compulsory Paradigm in International Adjudication: elements of a Theory of Consent. Journal of International Law and Politics. New York University, 2007, v. 39, n. 791. pp. 805-6).
} 
fortemente fundamentadas em KANT, as quais possuíam um viés combativo da noção de anarquia internacional até então vigente ${ }^{51}$.

Tais aspirações promoveram um considerável desenvolvimento desse ramo do Direito $^{52}$ e refletiram na formação da Liga das Nações, da Organização Internacional do Trabalho (OIT) e na expansão e fortalecimento do direito humanitário. O Direito Internacional passou, então, a adquirir feições de institucionalização.

Da mesma forma, a solução pacífica de controvérsias passou a ganhar densidade e suporte na ordem jurídica. Cabe destacar o Pacto Briand-Kellog (1928) e o Pacto Saavedra Lamas (1933) como precursores na proibição do uso da força nas relações internacionais ${ }^{53}$, o que abriu caminho para o banimento da guerra na ordem internacional pós-1945. A força desses ideais, infelizmente, não resistiu às ideias belicistas e nacionalistas que emergiram no pós-Primeira Guerra e o mundo, mais uma vez, foi tragado para outro conflito mundial.

A Segunda Guerra Mundial representou uma ruptura temporária na construção e aperfeiçoamento do Direito Internacional, entretanto, com o seu fim, as mudanças trazidas foram tão numerosas e de tal relevância que marcaram o início de uma nova fase. A reconstrução de fundamentos e estruturas, cujo impulso se deu no pós-guerra, inaugurou o chamado Direito Internacional Contemporâneo, ou Pós-Moderno ${ }^{54}$.

Um grande passo dessa evolução foi, sem dúvida, o estabelecimento da Organização das Nações Unidas (ONU), em $1945^{55}$, cujo tratado constitutivo - a Carta de São Francisco - é considerada como verdadeiro documento fundamental da nova ordem jurídica internacional. DUPUY, no seu Curso Geral de Direito Internacional Público,

\footnotetext{
${ }^{51}$ Id., ibid., p. 152.

52 "On peut affirmer que le fait le plus frappant dans l'histoire du droit international depuis son origine, qui remonte à plus de trois siècles, est son devélopment extraordinaire pendant le siècle actuel. Il n'est pas un période de notre histoire, pas même l'époque de Grotius, qui ait vu autant que la présente des changements de une telle portée dans les relations des Etats et dans le droit que les gouverne. [...].” (GARNER, James W. Les devélopments et les tendences récentes du Droit International. RCADI, 1931-I, v. 35. pp. 605-720. p. 5).

53 Acrescente-se a esse rol a Doutrina Stimson de não reconhecimento de situações geradas pela força (1932) e a Conferência de Havana, de 1928 (CANÇADO TRINDADE, Antônio Augusto. A humanização do Direito Internacional. Belo Horizonte: Del Rey, 2006. pp.178-9).

54 "Terminados os dias da concepção estatizante uniformizadora do direito internacional, que se pautava pelas normas de coexistência entre os estados e somente entre esses se reconhecia a condição de sujeito, para ver instalado o direito internacional pós-moderno: dividido entre o anseio de construção e cooperação, com alguns laivos de implementação de patamar tendente à integração, em contextos específicos, de coesão econômica e de compartilhamento de valores, que permita superar algumas das dicotomias mais gritantes do direito internacional, como a sobrevivência da pretensão da exclusividade dos papéis estatais, no plano do direito e das relações internacionais, quando mais se vê a emergência e a atuação dos agentes não estatais." (CASELlA, Paulo Borba. Fundamentos do Direito Internacional Pós-Moderno. São Paulo: Quartier Latin, 2008 p. 67).

${ }_{55}$ TOMUSCHAT, Christian. International Law: ensuring the survival of mankind on the eve of a new century. RCADI, 1999, v. 281. pp. 9-438. p. 203-4.
} 
ministrado na Academia da Haia, em 2002, intitulado L'unité de l'ordre juridique international, atribui ao mencionado documento o status de constituição da nova ordem internacional, por exercer papel determinante na manutenção de sua unidade ${ }^{56}$.

Dentre as várias novidades, a Carta da ONU trouxe em seu bojo os princípios que deveriam pautar a recém-nascida ordem internacional, tanto na produção normativa, quanto na atuação de cada sujeito. MENEZES destaca que, embora já reconhecidos na consciência coletiva dos Estados e no costume internacional, os referidos princípios só foram condensados e sistematizados na referida Carta, em seu art. $2^{057}$. Nesse contexto, no parágrafo $3^{\circ 58}$ do dispositivo supracitado foi consagrado o princípio da solução pacífica de controvérsias.

Posteriormente, em 1970, após um longo período de estudos e negociações ${ }^{59}$, a Assembleia Geral das Nações Unidas concluiu sua Resolução n. 2.625 (XXV), mais conhecida como Declaração Relativa aos Princípios de Direito Internacional Regendo as Relações Amistosas e a Cooperação entre os Estados, conforme a Carta da ONU. Nesse documento ficou estabelecido, em primeiro plano, a obrigação positiva de todos os Estados de resolver suas controvérsias sem o uso da força ou de ameaça. E, em segundo plano, a obrigação de resultado de efetivamente resolver a contenda sem que essa se agrave ${ }^{60}$. No mesmo sentido, a Declaração de Manila sobre Solução Pacífica de Controvérsias, aprovada em 1982, é até mais enfática ao ressaltar o dever de resolver as controvérsias, sem colocar em risco a "paz, a segurança e a justiça"61.

O princípio que determina aos sujeitos do Direito Internacional resolver suas controvérsias de maneira pacífica é hoje reconhecido como uma norma pertencente ao rol do jus cogens ${ }^{62}$. Aos Estados, contudo, foi dada a liberdade de escolher o meio que mais

\footnotetext{
${ }^{56}$ DUPUY, Pierre-Marie. L'unité de l'ordre juridique international: cours général de droit international public. RCADI, 2002, v. 297. pp. 9-489. p. 216.

${ }^{57}$ MENEZES, Wagner. A Jurisdicionalização do Direito Internacional: conflitos de competência entre Tribunais Internacionais, mecanismos de prevenção e resolução. Tese de Livre-docência apresentada à Faculdade de Direito da Universidade de São Paulo (FDUSP), 2012. p. 119.

${ }^{58}$ A Carta das Nações Unidas prega: "Todos os membros deverão resolver suas controvérsias internacionais por meios pacíficos, de modo que não sejam ameaçadas a paz, a segurança e a justiça internacionais." (RANGEL, Vicente Marotta. Direito e relações internacionais. 8. ed. rev., atual. e ampliada. São Paulo: Revista dos Tribunais, 2005. p. 28).

${ }^{59}$ Ver CANÇADO TRINDADE, Antônio Augusto. Princípios do Direito Internacional Contemporâneo. Brasília: Ed. da Universidade de Brasília, 1981. pp. 51-80.

${ }^{60}$ ARANGIO-RUIZ, Gaetano. The normative role of the General Assembly of the United Nations and the Declaration of Principles of Friendly Relations. With an appendix on The Concept of International Law and the Theory of International Organizations. RCADI, 1972-III, v. 137. pp. 419-742. p. 540.

${ }^{61}$ ORGANIZAÇÃO DAS NAÇÕES UNIDAS. Assembleia Geral. Resolução 37/10. $68^{\circ}$ Encontro Plenário. 15 de novembro de 1982.

${ }^{62}$ MENEZES, Wagner. Tribunais Internacionais: jurisdição e competência. São Paulo: Saraiva, 2013. p. 112
} 
lhes convier, como estabelece o art. 33 da Carta das Nações Unidas, que não obriga a utilização de um método específico. Conclui-se dessa premissa que não há uma hierarquia formal entre os meios de solução pacífica de controvérsias ${ }^{63}$. É importante ressaltar, entretanto, que a livre escolha é mais uma faculdade do que um princípio, podendo ser suprimida por acordo ou por determinação contrária ${ }^{64}$.

Como supramencionado, o Direito Internacional Contemporâneo passou a regular uma série de situações que não eram de interesse internacional à época das Conferências de Paz da Haia, quando os meios pacíficos de solução de controvérsias foram sistematizados. Hoje, com a aceitação crescente da personalidade jurídica internacional do indivíduo e de sua capacidade postulatória internacional não é mais possível admitir uma ampla liberdade aos Estados para escolherem como resolverão determinado litígio. Em algumas situações, a resolução de um conflito internacional por terceiros e de forma institucional é necessária para a manutenção do equilíbrio e dos valores da comunidade internacional como um todo $^{65}$.

A doutrina e a jurisprudência internacional classificam os meios pacíficos de solução de controvérsias em três classes: os diplomáticos, os políticos e os jurídicos. BARBERIS propõe uma diferenciação simples, contudo, precisa: os diplomáticos e os políticos logram a solução das contendas mediante a elaboração de um tratado, já os jurídicos o fazem pela força de uma sentença, judicial ou arbitral ${ }^{66}$. No mesmo sentido, RANGEL diferencia os processos políticos dos jurídicos na medida em que os estes resultam em uma decisão com força de res iudicata, resultante da aplicação do Direito Internacional e realizada com um alto grau de tecnicismo e de organicidade ${ }^{67}$.

\footnotetext{
${ }^{63}$ SHAW, Malcolm. International Law. $6^{\text {th }}$ ed. Cambridge: Cambridge University Press, 2010. p. 1014.

${ }^{64}$ CANÇADO TRINDADE. Antonio Augusto. International Law for Humankind: towards a new Jus Gentium (II). General Course on Public International Law. RCADI, 2005, v. 315. pp. 9-312. p. 211.

65 "There is a greater awareness nowadays that peaceful settlement of international disputes transcends the interests of contending States, and is in keeping with the general interests of the international community as a whole. It does in fact constitute a response to the necessities and requirements of contemporary international relations. Recent initiatives such as those of a compulsory recourse to conciliation as well as to fact-finding, and the growing emphasis on prevention of disputes, are illustrative of the aforementioned greater awareness. Here the recourse to such methods is what becomes binding, even though the solution or outcome is not compulsory. But this trend likewise illustrates the growing awareness of the relevance of peaceful settlement, to the ultimate benefit not only of the contending parties themselves but of the international community as a whole. In a vulnerable world such as ours, the fate of onde appears linked to that of the others." (Id., ibid., p. 214).

${ }^{66}$ BARBERIS, Julio A. Formación del derecho internacional. Buenos Aires: Editorial Ábaco de Rodolfo Depalma, 1994. p. 178.

67 RANGEL, Vicente Marotta. Jurisdição Internacional: considerações preambulares. In: Estudos em homenagem à professora doutora Isabel de Magalhães. Coimbra: Almedina, 2007. pp. 643-652. p. 645.
} 


\subsubsection{Processo histórico da jurisdicionalização do direito internacional}

A adjudicação no Direito Internacional remonta ao ano de 1794, quando o Tratado Jay firmado entre os Estados Unidos e a Grã-Bretanha concebia uma estrutura dotada de três câmaras mistas para lidar com as questões que não constavam em seu texto. Posteriormente, em 1872, foi constituído o Alabama Claims Arbitration pelo Tratado de Washington, de 1871, novamente entre os dois países já citados, com o objetivo de analisar possíveis violações da neutralidade da antiga metrópole na Guerra Civil Americana ${ }^{68}$. A partir do sucesso desses procedimentos, a arbitragem voltou a compor a cena da solução de controvérsias até atingir seu reconhecimento máximo nas Conferências de Paz da Haia, com a criação da Corte Permanente de Arbitragem (CPA) ${ }^{69}$.

Assim, as Conferências de Paz da Haia, em sintonia com os já tradicionais meios diplomáticos de solução de controvérsias - notadamente: os bons ofícios, as negociações diretas e a mediação - deram importante destaque a um meio jurídico: a arbitragem, já defendida por filósofos e juristas desde a Idade Antiga ${ }^{70}$ como o meio mais propício para se perpetuar a paz ${ }^{71}$.

As convenções sobre meios pacíficos de solução de controvérsias assim definiam a arbitragem no art. 15, da primeira, e no art. 37 da segunda, ambos de redação idêntica: "A arbitragem internacional tem por objetivo a solução dos litígios entre os Estados, por juízes de sua escolha e sobre a base do respeito do direito"72.

Assinale-se que o uso da expressão "respeito do direito" é quase tão significativo quanto o instituto cujo conceito integra, uma vez que ao deixar clara tal informação, reforçou-se o seu caráter eminentemente jurídico ${ }^{73}$. Marca-se, assim, a posição da sociedade internacional da época em primar pela aplicação das normas vigentes de seu

\footnotetext{
${ }^{68}$ HUDSON, Manley O. International Tribunals past and future. Washington: Carnegie Endowment for International Peace and Brookings Institution, 1944. pp. 3-5, passim.

${ }^{69}$ Id., ibid., pp. 6-7.

${ }^{70}$ KOFF, Serge. Introduction a L'Histoire du Droit International. RCADI, 1923, v. 1. pp. 5-23. p. 12.

71 "A toutes les époques du monde, les esprits généreux et humains ont vu dans l'arbitrage international, envisagé sous son double aspect le moyen le plus sur de fonder le régne de la paix parmi les peuples." (FAUCHILlE, Paul. Traité de Droit Internacional Public. Tome $1^{\text {er }}$ Troisième Partie. Paix. 8. ed. Entièrement refondue, complétée et mise au courant, du Manuel de droit international public de M. Henry Bonfils. Paris : Roussau \& Cie, Editeurs, 1926. p. 537).

${ }_{72}$ ACCIOLY, Hildebrando. Tratado de Direito Internacional Público. São Paulo: Quartier Latin, 2009, v. III. p. 38.

${ }^{73}$ Entretanto, em 1928, o Ato Geral de Genebra adotou uma outra posição, facultando à arbitragem, se assim preferissem os Estados envolvidos, resolver tanto os ditos conflitos políticos, quanto os jurídicos (Id., ibid., p. 38).
} 
ordenamento jurídico, revelando, desse modo, uma preferência pelos ainda embrionariamente sistematizados meios jurídicos para a solução de suas controvérsias ${ }^{74}$.

Em funcionamento até os dias de hoje, a CPA localiza-se na Haia e foi responsável pela resolução de um número significativo de litígios que envolviam Estados e também particulares de uma maneira geral, o que contribuiu de forma abrangente para a evolução do Direito Internacional ${ }^{75}$. Ressalte-se, contudo, que muito embora se trate de um meio jurídico de solução de controvérsias, a arbitragem internacional não era considerada, em sua forma clássica, um meio judiciário, e sim administrativo ${ }^{76}$.

As diferenças entre os tribunais arbitrais internacionais e os judiciários são claras e se referem, em primeiro plano, a questões procedimentais. A mais notória decorre do fato de que no primeiro caso as partes escolhem o terceiro, ou terceiros, que vão decidir a questão controversa. Já no segundo, o caso é decidido por um colegiado pré-estabelecido de juízes independentes, detentores de um mandato que lhes outorga o poder jurisdicional $^{77}$.

Seguindo esse raciocínio, o primeiro tribunal judiciário internacional foi a Corte Centroamericana de Justiça $(\mathrm{CCJ})^{78}$. Fruto da Conferência de Paz de Washington, de 1907, a CCJ começou suas atividades no ano seguinte, na cidade de Cartago, Costa Rica ${ }^{79}$. Embora considerada uma Corte à frente do seu tempo ${ }^{80}$, suas atividades encerraram dez anos após seu início, em 1918. Seu tratado constitutivo - a "Convenção para o

${ }^{74}$ MENEZES, Wagner. Tribunais Internacionais: jurisdição e competência. São Paulo: Saraiva, 2013. p. 133.

75 “Ao longo da História, vários foram os conflitos resolvidos pela arbitragem e o amadurecimento do Direito Internacional mais institucionalizado deve ser tributado a ela. Mesmo antes da Primeira Guerra Mundial o instituto foi largamente utilizado, mas com a jurisdicionalização da sociedade internacional, teve reduzida significativamente sua atuação. Em que pese, é uma instituição sempre pronta a cooperar com os Estados e com a solução pacífica de conflitos, tendo se mantido ativa e de grande importância para o sistema internacional, proferindo decisões importantes.” (MENEZES, Wagner. Op. cit., 2013, p. 160).

${ }^{76}$ Id., ibid.

77 "La justice internationale se distingue de l'arbitrage par le fait que ceux qui sont appelés à la rendre échappent au choix des parties.” (REUTER, Paul. Droit international public. Paris: Presses Universitaires de France, 1993. p. 377).

78 De acordo com os critérios de classificação propostos por Menezes, trata-se de uma corte ou tribunal regional especializado (MENEZES, Wagner. Op. cit., 2013, pp. 163-168, passim).

${ }^{79}$ De acordo com Grieves, a CCJ foi: "[...] A product of the 'Hague spirit', the Central American Court of Justice was a full-fledged, permanent international court of law. Undoubtedly the most supranational tribunal ever devised, the Central American Court, when compared with other international courts, possessed an incredible broad jurisdiction. [...]." (GRIEVES, Forest. Supranationalism and international adjudication. Chicago: University of Illinois Press, 1960. p. 19).

80 JORDISON, Sasha Maldonado. The Central American Court of justice: yesterday, today and tomorrow? Connecticut Journal of International Law. 2009-2010, v. 25, n. 183. p. 195. 
Estabelecimento da Corte Centroamericana de Justiça" - possuía vigência apenas para dez anos, mas podia ser renovado, o que não aconteceu devido a questões políticas ${ }^{81}$.

A Corte Permanente de Justiça Internacional (CPJI) ${ }^{82}$ originou-se no âmbito da Liga das Nações, mais especificamente por determinação do art. 14 de seu Pacto, constituindo-se na primeira corte internacional judiciária permanente e de caráter universal - tanto material quanto geográfico. Em seus 24 anos de existência (1922-1946), a CPJI proferiu cerca de 79 decisões, entre casos contenciosos e pareceres consultivos. Ademais, contribuiu de maneira significativa para a construção do Direito Internacional de sua época $^{83}$. Com o começo da Segunda Guerra Mundial, contudo, essa instituição pereceu junto com sua organização patrocinadora, tendo resolvido seus últimos casos no ano de $1939^{84}$.

Surgida dos espólios da CPJI, a Corte Internacional de Justiça foi concebida no seio da ONU na qualidade de seu órgão judiciário. Herdou, também, a classificação de tribunal universal, uma vez que sua competência em razão da pessoa alcança todos os Estados que consentem com sua jurisdição e, em razão da matéria, todas as que lhe são submetidas ${ }^{85}$.

Até a década de 50 os Estados contavam apenas com a CIJ e com a CPA como instituições capazes de solucionar juridicamente os seus conflitos. A institucionalização promovida pela ONU e a diversificação temática do Direito Internacional - sistema econômico, direitos humanos, blocos regionais - no entanto, criaram novos espaços de jurisdição internacional tanto na esfera global quanto na regional. Vários outros tribunais internacionais das mais diferentes áreas passaram a ser estabelecidos desde então ${ }^{86}$.

Os tribunais internacionais constituídos nas décadas que se seguiram são os chamados "regionais especializados", ou seja, aqueles cuja competência em razão da pessoa tem por requisito a localização do sujeito em porção territorial especificada, e a competência em razão da matéria é limitada a um determinado ramo do Direito Internacional. Como exemplos à época podem ser citados: o Tribunal de Justiça da

\footnotetext{
${ }^{81}$ MENEZES, Wagner. Tribunais Internacionais: jurisdição e competência. São Paulo: Saraiva, 2013. p. 194.

${ }^{82}$ CALOYANNI, Mégalos A. L'Organisation de la Cour Permanente de Justice International et son Avenir. RCADI, 1931-IV, v. 38. pp. 651-786. pp. 664-5.

${ }^{83}$ GARNER, James W. Les Devélopments et les tendences récentes du droit international. RCADI, 1931I, v. 35. p. 59.

${ }^{84}$ Id., ibid., p. 152.

85 “Art. 36 (1). A competência da Corte abrange todas as questões que as partes lhes submetam, bem como todos os assuntos especialmente previstos na Carta das Nações Unidas ou em tratados e convenções em vigor.” (RANGEL, Vincente Marotta. Direito e relações internacionais. 8. ed. rev., atual. e ampliada. São Paulo : Revista dos Tribunais, 2005. p. 56).

${ }^{86}$ MENEZES, Wagner. Tribunais Internacionais: jurisdição e competência. São Paulo: Saraiva, 2013. p. 139.
} 
Comunidade Europeia, a Corte Europeia de Direitos Humanos e a Corte Interamericana de Direitos Humanos.

No plano global, o avanço na criação de novos tribunais internacionais, especialmente os especializados, não foi, contudo, significativo no mesmo contexto, em razão do momento histórico-político da sociedade internacional, que enfrentava os anos de Guerra Fria. O fim desse período histórico, que coincide com a década final do século XX, veio acompanhado de uma significativa institucionalização do Direito Internacional que resultou no fenômeno denominado "multiplicação de tribunais internacionais".

Para explicar esse fenômeno, KARAGIANNIS apresenta apenas duas justificativas gerais. A primeira seria a insuficiência das jurisdições internacionais preexistentes, mais especificamente da CPA e da CIJ, que não acompanharam a evolução do Direito e da sociedade internacional. A segunda fica por conta da regionalização do DIP, que veio acompanhada de equipamentos institucionais, bem como cortes internacionais ${ }^{87}$.

Já ROMANO aponta três fatores inter-relacionados para explicação da expansão do fenômeno na década de 90: i) o fim da bipolaridade; ii) o abandono das teorias marxistasleninistas de interpretação do Direito Internacional; e, segundo o autor, a mais relevante, iii) o fato da prevalência das economias capitalistas baseadas no mercado e doutrinas de livre comércio como única via para o desenvolvimento econômico ${ }^{88}$.

RAMOS, por sua vez, explica o fenômeno por intermédio das seguintes hipóteses: i) a necessidade de sofisticados sistemas de solução de controvérsias diante de normas igualmente sofisticadas de Direito Internacional; ii) o crescente abandono, por vários Estados, de suas aspirações militares; iii) a queda do socialismo e ascensão das democracias liberais, reforçando o diálogo e a confiança mútuos; iv) o reforço positivo de algumas experiências jurisdicionais no século XX, como a Corte Europeia de Direitos Humanos e o Tribunal Europeu; e, v) a dificuldade de adaptação da Corte Internacional de Justiça aos novos tipos de litígios ${ }^{89}$.

Seguindo a lógica da multiplicação dos tribunais internacionais, passadas as intempéries do mundo bipolarizado, o ambiente político favorável possibilitou o estabelecimento de três novos órgãos judiciais internacionais especializados permanentes

\footnotetext{
${ }^{87}$ KARAGIANIS, Syméon. La multiplication des Jurisdictions Internationales: un systeme anarchique? In: SOCIETÉ FRANÇAISE POUR LE DROIT INTERNATIONAL. La Juridictionnalisation du Droit International. Colloque de Lille. Paris: Pedone, 2003. pp. 7-161.

${ }^{88}$ ROMANO, Cesare P.R. The proliferation of international judicial bodies: the pieces of the puzzle. Journal of International Law and Politics. New York University, 1999, v. 31, n. 709. pp. 709-51. p. 729.

${ }^{89}$ RAMOS, André de Carvalho. Direitos humanos na integração econômica. Análise comparativa da proteção de direitos humanos e conflitos jurisdicionais na União Europeia e Mercosul. Rio de Janeiro: Renovar, 2008. pp. 375-7, passim.
} 
na esfera universal: o Órgão de Apelação da Organização Mundial do Comércio, o Tribunal Internacional para o Direito do Mar, e o Tribunal Penal Internacional. Além desses, o Conselho de Segurança da ONU determinou a criação de outros dois tribunais penais internacionais ad hoc - o Tribunal Penal Internacional para Antiga Iugoslávia e o Tribunal Penal Internacional para Ruanda - e de tribunais penais híbridos ${ }^{90}$ - o Tribunal Especial para a Serra Leoa e o Tribunal Penal Internacional para o Líbano, dentre outros estabelecidos por diferentes meios.

MENEZES atribui a importância desses tribunais especializados universais ao fato deles encarnarem a jurisdicionalização da sociedade internacional "por terem sido criados nos últimos anos e de sua vocação temática para resolver temas que são afetos a toda sociedade internacional" $"$.

O processo histórico de jurisdicionalização do Direito Internacional levantou uma série de questões conceituais relacionadas à existência, funcionamento e influência desses órgãos judiciais internacionais. Essas inquietações são de fundamental importância para a compreensão do fenômeno jurídico internacional contemporâneo e serão ventiladas a seguir.

1.2 JURISDIÇÕES INTERNACIONAIS, TRIBUNAIS INTERNACIONAIS E A JURISPRUDÊNCIA INTERNACIONAL: ANÁLISE CONCEITUAL À LUZ DO DIREITO INTERNACIONAL CONTEMPORÂNEO

\subsubsection{Conceito de Tribunais Internacionais}

Definir um conceito para tribunais internacionais não parece ser uma tarefa fácil para a doutrina jusinternacionalista. As dificuldades em fazê-lo são muitas, tendo em vista as diferenças entre esses órgãos. Existem aqueles que foram constituídos por tratados, enquanto outros surgiram de resoluções do Conselho de Segurança da ONU. Há os

\footnotetext{
90 'These tribunals are referred to as 'hybrid' or 'internationalized' because both the institutional apparatus and the applicable law consist of a blend of the international and the domestic, resulting in a mixed form of justice. Such tribunals employ the efforts of both the international community and the state in which the alleged crimes occurred. Over the past two decades several hybrid tribunals have been created, including the Regulation 64 Panels in Kosovo; the Special Panels for Serious Crimes (SPSC) in Dili, East Timor; the Extraordinary Chambers in the Courts of Cambodia (ECCC) in Phnom Penh; the Special Court for Sierra Leone (SCSL) in Freetown; and most recently the Special Tribunal for Lebanon (STL) in The Hague, The Netherlands." (RAUB, Lindsay. Positioning hybrid tribunals in International Criminal Justice. International Law and Politics Journal, 2009, v. 41. pp. 1013-53. p. 1016).

${ }^{91}$ MENEZES, Wagner. Tribunais Internacionais: jurisdição e competência. São Paulo: Saraiva, 2013. p. 203.
} 
constituídos em razão de uma situação específica, $a d$ hoc, e os permanentes. Uns são parte de organizações internacionais, já outros possuem personalidade jurídica própria. Alguns admitem o acesso de indivíduos, ONGs e empresas, enquanto outros só permitem Estados. O processo decisório também difere: há aqueles cujas decisões são tomadas pelo pleno, enquanto em outros essas decisões são tomadas por câmaras. Quanto à própria nomenclatura, entretanto, pode-se afirmar que "corte" é sinônimo de "tribunal"?

MENEZES aponta neste cenário, para alguns problemas surgidos da indefinição conceitual de tribunais internacionais. O primeiro diz respeito às instituições às quais é atribuída uma capacidade decisória administrativa, mais conhecidas como quasi-judiciais, que acabam sendo confundidas como verdadeiros tribunais internacionais. Também ventila a insegurança etimológica surgida das palavras "corte" e "tribunal" e o cuidado de examinar se o órgão que leva esse nome realmente faz jus ao termo. Por fim, discorre sobre a inexatidão de vincular como sinônimos as expressões "meios jurídicos" e "tribunais internacionais" $" 92$.

Em um sentido amplo, o conceito de tribunais internacionais pode parecer óbvio se considerado sob a perspectiva de seu objetivo geral no seio do sistema jurídico internacional contemporâneo, isto é: resolver pacificamente as controvérsias internacionais, por terceiros, de maneira institucionalizada, evitando as represálias e a guerra $^{93}$. A conceituação pelo objetivo geral, contudo, peca justamente na generalidade, pois os mecanismos políticos também se encaixariam perfeitamente na definição.

Igualmente imprecisa é a conceituação terminológica. Etimologicamente, os termos "tribunal" e "corte" variam de significado nos vários idiomas. RANGEL afirma que essa diferença "não resulta de nenhum critério conceitual relevante e, em grande parte, dimana do texto estrangeiro (que faça fé) utilizado de base de tradução" ${ }^{94}$. Por sua vez, ROMANO adota o termo "órgãos judiciais internacionais", pois, segundo ele, "há uma confusão substancial" no uso dos dois termos anteriormente citados ${ }^{95}$.

\footnotetext{
${ }^{92}$ MENEZES, Wagner. Tribunais Internacionais: jurisdição e competência. São Paulo: Saraiva, 2013. pp. $145-6$.

${ }^{93}$ Essa percepção é compartilhada por Goggenheim, para quem o órgão judicial é aquele, arbitral ou judiciário, constituído pelos Estados, por convenções internacionais, e encarregados de executar o direito. Acrescenta que sua tarefa é solucionar as controvérsias de maneira a evitar que as partes recorram aos meios coercitivos, represálias ou guerra. (GUGGENHEIM, Paul. Traité de droit international public. Genève: Librailie de l'Université, Georg \& Cie S.A., 1954. p. 102).

${ }_{94}$ RANGEL, Vicente Marotta. Jurisdição Internacional: considerações preambulares. In: Estudos em homenagem à professora doutora Isabel de Magalhães Colasso. Coimbra: Almedina, 2007. pp. 643-652. p. 643.

95 "In particular, there exists substantial confusion as to both the terms employed to describe the phenomenon and the notion itself." (ROMANO, Cesare P. R. The proliferation of international judicial
} 
SCELLE, em seu Règles Générales du Droit de la Paix, esboça um conceito de tribunais internacionais ao fazer um estudo da diferença entre a jurisdição arbitral e a jurisdição institucional, que segundo ele, é a “jurisdição propriamente dita”. Para o autor, uma instituição judiciária internacional é aquela que cita o sujeito de direito em uma determinada controvérsia a se apresentar perante juízes nomeados ou eleitos, independentemente da vontade das partes ${ }^{96}$.

KELSEN, por sua vez, atribui a alcunha de "tribunal internacional" àquelas instituições que possuem juízes como membros, competência para resolver disputas internacionais, aplicando o Direito Internacional e, no caso de ser um colegiado, se prevalecer o voto da maioria no desfecho ${ }^{97}$.

Vários outros elementos foram escolhidos por diversos doutrinadores como critérios determinantes do conceito. DELBEZ, por exemplo, considerava um tribunal internacional aquela instituição que possuía juízes de várias nacionalidades e, com base no Direito Internacional, em que residia a autoridade de sua decisão, decidia ao final de um processo internacional $^{98}$.

Os elementos ligados aos ritos processuais, como o contraditório e a sentença final obrigatória, são parte fundamental dos conceitos formulados por DINH, DAILLER e PELLET $^{99}$ e DIEZ DE VELASCO ${ }^{100}$. Já o critério da permanência do órgão se destaca na

bodies: the pieces of the puzzle. Journal of International Law and Politics. New York University, 1999, v. 31, n. 709, pp. 709-51. p. 711).

${ }^{96}$ SCELLE, Georges. Règles générales du droit de la paix. RCADI, 1933-IV, t. 46. pp. 327-703. p. 574.

${ }^{97}$ KELSEN, Hans. Principles of International Law. 2. ed. New York: Holt, Rinehart and Wiston, 1966. pp. $522-3$.

${ }_{98}$ DELBEZ, Louis. Les príncipes généraux du contentieux international. Paris: LGDJ, 1969. pp. 44-5.

99 "Nesse tipo de resolução estão com efeito reunidos os elementos fundamentais da função jurisdicional: uma decisão fundada sobre considerações jurídicas, obrigatória para as partes, pronunciada por um órgão independente das partes no litígio, na sequência de um processo contraditório e garantindo os direitos de defesa e igualdade das partes." (DINH, Nguyen; DAILLER, Patrick; PELLET, Alain. Direito Internacional Público. Trad. de Vítor Marques Coelho. 2. ed. Lisboa: Fundação Calouste Gulbenkian, 2003. p. 879).

100 "Se trata de um medio de solución de naturaleza jurídica, caracterizado por la intervención de órganos compuestos por jueces plenamente independientes de as partes en la controversia, que ejercen sus competencias, normalmente de forma permanente, através de um procedimiento judicial de caráter contradictiorio y que resuelven la diferencia que les es sometida mediante sentencias que tienen siempre caráter obligatorio para las partes en el litígio." (VELASCO, Manuel Diez de. Instituiciones de Derecho Internacional Público. 15. ed. Madrid: Tecnos, 2005. p. 905). 
formulação de ACCIOLY, NASCIMENTO E SILVA, e CASELLA $^{101}$ e de TOMUSCHAT $^{102}$.

PASTOR RIDRUEJO propõe um conjunto de elementos que caracterizam um órgão jurídico de solução de controvérsias, e sugere cinco elementos comuns aos tribunais arbitrais e judiciais. Assim, de acordo com o autor, constituem um tribunal ou corte internacional aquelas instituições que: i) resolvem a controvérsia por um terceiro imparcial; ii) têm essa competência fundamentada na vontade dos Estados; iii) utilizam-se do contraditório em seus procedimentos; iv) examinam os casos com base no Direito Internacional; e v) os membros se submetem de boa fé às decisões proferidas ${ }^{103}$.

ROMANO, em sua formulação, adapta o conceito proposto por TOMUSCHAT no sentido de abarcar o maior número de elementos possíveis e, assim, atingir um conceito mais preciso. De acordo com o autor, um órgão judicial internacional é aquele que: i) é permanente, no entanto, esse critério é flexível; ii) estabelecido por um instrumento jurídico internacional; iii) toma suas decisões com base no Direito Internacional por intermédio de um processo com regras preestabelecidas e de difícil modificação, cuja sentença final seja juridicamente vinculante; iv) composto por juízes escolhidos de forma imparcial; e v) que decida casos nos quais pelo menos uma parte é um Estado soberano ou organização internacional ${ }^{104}$.

Em sua tese de livre docência, defendida no ano de 2012, MENEZES propõe um conceito cujo elemento principal é a jurisdição ${ }^{105}$. Essa seria o núcleo de um tribunal ou corte internacional, na medida em que atribui ao órgão a capacidade de formar um juízo que lhe permita decidir o caso de maneira definitiva e obrigatória, sendo que a não observância do julgado incorrerá em um ilícito internacional. Logo, para o autor:

\footnotetext{
101 "Os tribunais e as cortes internacionais são entidades judiciárias permanentes, compostas de juízes independentes, cuja função é o julgamento de conflitos internacionais, tendo como base o direito internacional, de conformidade comum processo preestabelecido e cujas sentenças são obrigatórias para as partes." (ACCIOLY, Hildebrando; NASCIMENTO E SILVA, G.E.; CASELLA, Paulo Borba. Manual de Direito Internacional Público. 17. ed. São Paulo: Saraiva, 2009. p. 773).

${ }^{102}$ TOMUSCHAT, Christian. International Courts and Tribunals. In: Max Planck Encyclopedia of Public International Law, 1981, v. 1. pp. 92-3.

${ }^{103}$ PASTOR RIDRUEJO, José Antonio. Le droit international à la veille du vingt et unième siècle: normes, faits et valeurs: cours général de droit international public. RCADI, 1998, t. 274, pp. 9-308. p. 100.

${ }^{104}$ ROMANO, Cesare P. R.. The proliferation of international judicial bodies: the pieces of the puzzle. Journal of International Law and Politics. New York University, 1999, v. 31, n. 709, pp. 713-5.

105 "O poder jurisdicional deve estar vinculado a uma gama de direitos existentes, ou reconhecidos como sendo invocáveis pelos Estados. É esse corpo normativo que irá permitir uma análise jurídica do caso concreto, a partir de pressupostos normativos, de regras, princípios, costumes, normas que dão vida ao exercício jurisdicional do órgão de julgamento." (MENEZES, Wagner. Tribunais Internacionais: jurisdição e competência. São Paulo: Saraiva, 2013. p. 148).
} 
Os Tribunais ou Cortes Internacionais são órgãos autônomos, dotados de poder jurisdicional conferido pelos Estados, com competência para dirimir, sob a égide do Direito Internacional, questões ligadas à sua aplicação, por meio de um rito processual e procedimental judiciário que tem seu fim em uma sentença que deve ser obrigatoriamente cumprida pelas partes ${ }^{106}$.

Além do poder jurisdicional ${ }^{107}$, a autonomia do órgão também é imprescindível na concepção do professor MENEZES, assim como a previsibilidade e a segurança de um tribunal internacional preestabelecido ou legitimamente constituído, cujos ritos processuais já estejam predeterminados no estatuto ou no ato internacional constitutivo ${ }^{108}$.

No campo da jurisprudência, na opinião consultiva referente aos efeitos dos julgamentos do Tribunal Administrativo das Nações Unidas, a Corte Internacional de Justiça também ressaltou a jurisdição como elemento caracterizador do órgão judicial internacional. De acordo com o parecer, podem ser assim considerados os órgãos que no exercício de suas funções delimitadas, prolatam uma sentença definitiva, sem possibilidade de recurso, gerando a coisa julgada entre as partes da controvérsia ${ }^{109}$.

Assim, não é incorreto chamar um tribunal internacional de "jurisdição internacional", mas é importante atentar para o fato de que aqueles são espécies dessa. Uma vez estabelecida como nuclear no conceito de tribunais internacionais, cabe uma análise mais detida de seus contornos, desenvolvimento, e a problemática no seio do Direito Internacional Contemporâneo.

\subsubsection{Jurisdição Internacional: conceito e principais questões}

Jurisdição é o poder, função e atividade mediante o qual o Estado substitui as partes de uma determinada controvérsia para resolvê-la de forma definitiva e imparcial ${ }^{110}$. Tratase de uma expressão do poder soberano estatal e, por isso, é considerada indivisível, uma

\footnotetext{
106 MENEZES, Wagner. Tribunais Internacionais: jurisdição e competência. São Paulo: Saraiva, 2013. p. 151

${ }^{107} \mathrm{O}$ poder jurisdicional figura como um poder legítimo a atuar no cenário internacional. Um poder jurídico que não pode ser confundido com o poder que serve de base de análise dos realistas na Teoria das Relações Internacionais. (Id., ibid.).

${ }^{108}$ Id., ibid., p. 151.

${ }^{109}$ INTERNATIONAL COURT OF JUSTICE. Effect of Awards of Compensation Made by the United Nations Administrative Tribunal. Advisory Opinion of July $13^{\text {th }}$, 1954. Reports of Judgments, Advisory Opinions and Orders, 1954. p. 53.

110 "Vista assim, a jurisdição é a atividade pública e exclusiva com a qual o Estado substitui a atividade das pessoas interessadas e propicia a pacificação de pessoas ou grupos em conflito, mediante a atuação da vontade do direito em casos concretos." (DINAMARCO, Cândido Rangel. Fundamentos do Processo Civil Moderno. São Paulo: Malheiros, 2002, tomo I. p. 115).
} 
vez que diversas jurisdições implicam em diversas soberanias dentro de um Estado ${ }^{111}$. Do mesmo modo, essa se impõe sobre o mesmo e todos seus cidadãos, prescindindo de sua vontade $^{112}$.

$\mathrm{Na}$ Academia de Direito Internacional em Haia, em duas oportunidades MANN ${ }^{113}$ expôs suas reflexões sobre a jurisdição no Direito Internacional, mantendo a compreensão de que essa é um direito do Estado, atribuído pelo DIP, para regular condutas relativas a matérias que não são exclusivamente de interesse doméstico ${ }^{114}$.

No mesmo sentido, SHAW expressa que a jurisdição é o "poder dos Estados sob o Direito Internacional para regular, ou, de alguma maneira, impactar sobre pessoas, propriedade e circunstâncias". Afirma o autor que ela se reflete nos princípios de soberania, igualdade dos Estados e não interferência nos assuntos domésticos. Divide sua atuação entre executiva, legislativa e judiciária. Para ele, trata-se de um poder essencialmente vinculado à figura estatal ${ }^{115}$.

BRIERLY, por sua vez, alega que a jurisdição é um atributo dos Estados, que pode, entretanto, ser limitado pelo Direito Internacional. A esse fenômeno se dá, de acordo com o autor, erroneamente o nome de extraterritorialidade, pois cria uma ficção na medida em que a pessoa ou coisa jurisdicionada ainda se encontra no território do Estado e, também, porque sugere que jurisdição e território são conceitos coincidentes ${ }^{116}$.

Um conceito interessante é o proposto por SCHLOSSER, para quem a jurisdição é um atributo da soberania do Estado. Contudo, essa soberania é cada vez mais exercida com um espírito cooperativo, que traz reflexos no poder jurisdicional dos Estados e no plano internacional. Ainda há, no entanto, uma ligação intrínseca da jurisdição com o Estado ${ }^{117}$.

Por sua vez, LOWE admite que além do Estado, a jurisdição também pode ser atributo de outras "autoridades regulatórias", como a União Europeia. Para esse autor, o termo aqui em estudo descreve os limites da competência legal dos Estados e das outras

\footnotetext{
${ }^{111}$ Id., ibid., p. 156.

112 Id., ibid., p. 29.

${ }^{113}$ MANN, F. A.. The doctrine of jurisdiction in international law. RCADI, 1964, tomo 111. pp. 1-162; MANN, F. A. The doctrine of international jurisdiction revisited after twenty years. RCADI, 1984, tomo 186. pp. 9-116.

${ }^{114}$ Id., ibid., p. 9.

${ }^{115}$ SHAW, Malcolm N. International Law. $6^{\text {th }}$ ed. Cambridge: Cambridge University Press, 2010. p. 645.

${ }^{116}$ BRIERLY, J. L.. Direito Internacional. Trad. de M. R. Crucho de Almeida. 4. ed. Lisboa: Fundação Calouste Gulbenkian, 1979. p. 219.

117 "True, jurisdiction is an emanation of a State's sovereignty. But, sovereignty may be exercised in a cooperative spirit, as many examples of successful co-operation among States demonstrate. In the field of jurisdiction to prescribe, mankind has witnessed remarkable examples of co-operation in major fields of the law." (SCHLOSSER, Peter. Jurisdiction and international judicial and administrative co-operation. RCADI, 2000, t. 284. pp. 9-428. p. 27).
} 
autoridades regulatórias para fazer, aplicar e garantir regras de condutas às pessoas. $\mathrm{O}$ autor admite o uso da expressão para designar as atividades de cortes e tribunais internacionais, mas ressalta a importância de separar a forma internacional da interna ${ }^{118}$.

O termo "jurisdição internacional" advém de uma transposição do modelo dos direitos internos para a ordem internacional ${ }^{119}$. Logo, observa-se uma inadequação parcial, pois a sociedade internacional se caracteriza pela sua descentralização e pela constelação de Estados iguais e soberanos ${ }^{120}$. E, apesar de não possuir um poder soberano central, desenvolveu órgãos internacionais dotados de jurisdição para resolver seus conflitos.

De onde, então, advém o poder jurisdicional dos tribunais internacionais, uma vez que esses não se encontram abraçados por uma soberania específica? A jurisdição internacional se legitima na medida em que o Estado expressamente consente em se submeter a ela ${ }^{121}$, aderindo ao instrumento constitutivo de um tribunal. Esse é o sentido do conceito proposto por MENEZES:

\begin{abstract}
Assim, jurisdição internacional é a capacidade atributiva (poder) exercida por um Tribunal Internacional constituído a partir de um tratado, decorrente da vontade soberana dos Estados, no sentido de resolver os conflitos à medida que a ele sejam apresentados, em lugar daqueles que no conflito estão envolvidos, mediante a aplicação de uma solução contida no sistema jurídico normativo baseado na própria concepção do Direito Internacional, fontes, princípios e, principalmente, a vontade definidora e delimitadora dos Estados componentes da sociedade internacional ${ }^{122}$.
\end{abstract}

Há, também, a hipótese de atribuição da jurisdição internacional por consentimento tácito. Como exemplo podem ser citados os casos em que o Conselho de Segurança da ONU, no exercício de suas atribuições, cria tribunais penais internacionais ad hoc, ou delega jurisdição ao Tribunal Penal Internacional para investigar crimes cometidos por nacionais de países que não ratificaram o Estatuto de Roma ${ }^{123}$.

118 LOWE, Vaughan. Jurisdiction. In: EVANS, Malcolm D. International Law. New York: Oxford University Press, 2003. pp. 329-30.

119 ASCENSIO, Hervé. La notion de Jurisdiction Internationale en question. In: SOCIETÉ FRANÇAISE POUR LE DROIT INTERNATIONAL. La Jurisdictionalisation du Droit International. Colloque de Lille. Paris: Pedone, 2003. pp. 163-202. p. 168.

${ }^{120}$ LA PRADELLE, Géraud de Geouffre. La fonction des jurisdictions de l'ordre international. Journal du Droit International. 1998, $125^{\mathrm{e}}$ année, n. 2. pp. 389-429. p. 402.

121 "No direito internacional, a jurisdição tem de ser construída, e a extensão da jurisdição de um tribunal internacional, como da Corte Internacional de Justiça, dependerá da aceitação desta pelos Estados." (CASELLA, Paulo Borba. Fundamentos do Direito Internacional Pós-Moderno. São Paulo: Quartier Latin, 2008.p. 200.

${ }^{122}$ MENEZES, Wagner. Tribunais Internacionais: jurisdição e competência. São Paulo: Saraiva, 2013. p. 331.

${ }^{123}$ Ver, por exemplo, as resoluções do Conselho de Segurança da ONU: 827/1993 (determina a criação do Tribunal Penal Internacional para Antiga Iugoslávia); 955/1994 (determina a criação do Tribunal Penal Internacional para Ruanda); 1315/2000 (determina o estabelecimento do Tribunal Especial para Serra Leoa); 
Em 1999, na Sessão de Berlim, quando discutia a solução judiciária e arbitral de controvérsias envolvendo múltiplos Estados, o Instituto de Direito Internacional confirmou como princípio o caráter volitivo da jurisdição internacional. Segundo a celebrada organização, o consentimento dos Estados ainda é o fundamento da jurisdição dos tribunais e das cortes internacionais ${ }^{124}$.

Ao atuar na sociedade internacional contemporânea, a jurisdição internacional aqui entendida como espécie - exerce duas funções principais: a primeira, considerada como de imperium, pacifica os conflitos e legitima as ordens e sentenças das cortes e tribunais internacionais, tornando-as finais e obrigatórias, formando a coisa julgada. Já a segunda, a jurisdictio, constrói o Direito Internacional em cada decisão, dando corpo à jurisprudência internacional ${ }^{125}$. Embora sejam diferentes no que concerne à finalidade, ambas atuam juntas no exercício do poder jurisdicional ${ }^{126}$ internacional.

Outro ponto importante no estudo da jurisdição internacional é saber diferenciá-la de competência. Essa questão não era relevante quando a sociedade internacional dispunha de apenas um órgão judicial internacional para se socorrer diante de uma controvérsia. $\mathrm{O}$ processo de jurisdicionalização do Direito Internacional, porém, aumentou a gama de

1664/2006 (determina a criação do Tribunal Especial para o Líbano); 1593/2005 (atribui jurisdição para o TPI julgar os responsáveis por crimes de sua competência cometidos no Sudão); 1970/2011 (atribui jurisdição para o TPI julgar os responsáveis por crimes de sua competência cometidos na Líbia).

124 "Le consentement des Etats est le fondement de la compétence des cours et tribunaux internationaux; il en résulte qu'on ne peut pas se prononcer sur un litige impliquant plus de deux Etats sans le consentement de tous les Etats concernés. L'absence d'un tel consentement interdit d'aboutir à un règlement, ou ne permet qu'un règlement partiel $d u$ différend." (INSTITUT DE DROIT INTERNATIONAL. Le règlement judiciaire et arbitral des différends internationaux impliquant plus de deux Etats. Rapporteur $M$. Rudolf Benhardt. Session de Berlin, 1999).

125 "La fonction jurisdictionelle peut alors être décrite comme l'association au résultat de la phase de jurisdictio d'une part d'imperium." (ASCENSIO, Hervé. La notion de Jurisdiction Internationale en Question. In : SOCIETÁ FRANÇAISE POUR LE DROIT INTERNATIONAL. La Jurisdictionalisation du Droit international. Colloque de Lille. Paris: Pedone, 2003. p. 178).

${ }^{126}$ Carnelutti, processualista italiano, discorda dessa posição, e manifesta que jurisdição, ou seja, o ato de dizer o direito, difere do processo. Em suas palavras: "Questa distinzione è conforme al significato delle parole; mentre è certo che ius dicit il giudice quando dichiara che il debito vantato da Tizio contro Caio esiste o non esiste, è altrettanto certo che questa frase non si presta affatto, neanche in senso translato, a rappresentare la attivitá dell'ufficiale giudiziario che porta via $i$ suoi beni al debitore renitente. Non mi preoccupa che nel corso della storia e perfino nella legge attuale la parola 'giurisdizione' si trova usata, oltre i limiti del suo naturale significato, per indicare qualunque funzione processuale; questo uso è dovuto allá preponderanza, che há avulto il processo giurisdizionale nella lenta elaborazione del pensiero sui fenomeni processuali [...] La sinomia tra funzione processuale e funzione giurisdizionale è uma imperfezione del linguaggio e del pensiero, che la scienza del processo deve correggere se la prima esigenza del suo progresso è la purezza dei concetti e la proprietá dei vocaboli." (CARNELUTTI, Francesco. Sistema di Diritto Processuale Civile. I Funzione e Composizione del Processo. Padova: Casa Editrice Dott. Antonio Milani, 1936. p. 132). 
possibilidades e estruturas no sentido de viabilizar o acesso à justiça internacional, tornando a distinção conceitualmente necessária ${ }^{127}$.

Competência, neste caso, pode ser definida como a "quantidade de jurisdição cujo exercício é atribuído a cada órgão ou grupo de órgãos" ${ }^{\text {"128 }}$. Nos direitos internos, sua determinação é tarefa do constituinte e do legislador. No Direito Internacional, além da definição no sentido "legislativo" - ou seja, sua previsão nos tratados e estatutos das cortes e tribunais internacionais - os juízes também são competentes a dizer sua própria competência, delimitando-a, assim, pela jurisprudência ${ }^{129}$.

Ao se analisar os órgãos judiciais internacionais, a primeira referência à divisão de competências é aquela entre a contenciosa e a consultiva. A jurisdição atribuída pelos Estados a essas instituições se manifesta, portanto, nessas duas formas. A primeira se realiza na resolução dos litígios pelas regras do devido processo, encerrando em uma sentença obrigatória e definitiva. A segunda diz respeito à emissão de opiniões ou pareceres consultivos sobre questões jurídicas controversas - tanto processuais quanto materiais - sem possuírem, no entanto, caráter vinculante, muito embora o exercício dessa competência seja de extrema importância na gênese do próprio Direito Internacional ${ }^{130}$.

O exercício dessas, porém, só se dará se estiverem presentes, também, as competências em razão da matéria, da pessoa e do tempo ${ }^{131}$ - igualmente predeterminadas nos instrumentos constitutivos e na jurisprudência dos tribunais e cortes internacionais. Esses são os elementos necessários ao exercício do próprio poder jurisdicional. Se não estiverem presentes, mesmo havendo jurisdição, o tribunal não pode exercê-la ${ }^{132}$.

\subsubsection{A questão da "jurisdição" obrigatória}

127 MENEZES, Wagner. Tribunais Internacionais: jurisdição e competência. São Paulo: Saraiva, 2013. p. 331.

${ }^{128}$ CINTRA, Antonio Carlos de Araujo; GRINOVER, Ada Pellegrini; DINAMARCO, Cândido Rangel. Teoria geral do processo. 23. ed. São Paulo: Malheiros, 2007. p. 246.

129 Ver BERLIA, Georges. Jurisprudence des tribunaux internationaux en ce qui concerne leur compétence. RCADI, 1955-II, t. 88. pp. 105-57.

${ }^{130}$ ACCIOLY, Hildebrando; NASCIMENTO E SILVA, G. E.; CASELLA, Paulo Borba. Manual de Direito Internacional Público. 17. ed. São Paulo: Saraiva, 2009. p. 406.

${ }^{131}$ Para um estudo detalhado a respeito da utilização da CPJI e da CIJ sob a perspectiva material e espacial vide: VIRALLY, Michel. Le champ opératoire du réglement Judiciaire International. Revue Générale de Droit International Public, 1983. pp. 281-314.

132 "Enquanto jurisdição é um poder de decidir e por fim a um litígio dizendo o Direito, a competência é a função jurisdicional por meio da qual aquele poder se manifesta na sua extensão dentro dos limites impostos a ele. Um tribunal tem a jurisdição no sentido do poder normativo de dizer o Direito, contudo, pode lhe faltar competência se em razão da controvérsia não estiverem presentes elementos que permitam ao tribunal pronunciar-se sobre o caso. A jurisdição no seu sentido normativo não envolve necessariamente a competência no caso particular, que será determinada especificamente pelos limites estabelecidos pelos Estados mediante um Tratado." (MENEZES, Wagner. Tribunais Internacionais: jurisdição e competência. São Paulo: Saraiva, 2013. pp. 333-4). 
O estabelecimento de uma corte universal com jurisdição obrigatória é uma antiga pretensão da Filosofia. Nesse contexto, KANT se destacou como um dos primeiros a conceber a ideia do direito administrado universalmente, constituindo-se num grande desafio para humanidade ${ }^{133}$. KELSEN, por sua vez, afirmou que o único modo de se conquistar a paz é pelo Direito. O estabelecimento de uma Corte com jurisdição obrigatória sobre todos os conflitos humanos seria, então, o primeiro passo ${ }^{134}$. Posteriormente, HÖFFE defendeu seu modelo de democracia mundial ideal com a salvaguarda do Direito Internacional por um sistema de tribunais mundiais ${ }^{135}$. E, mais atualmente, FERRAJOLI aposta numa reforma da CIJ, dotando-a de caráter compulsório, abrindo-a para atores não estatais e lhe atribuindo competência criminal ${ }^{136}$.

Não obstante, a evolução do Direito Internacional ainda não alcançou o almejado no campo da Filosofia. De fato, a principal característica da jurisdição internacional é que essa é voluntária, pois só se vinculará àqueles Estados que a reconhecerem expressamente. Uma vez atribuída a um determinado tribunal internacional, não é certo, contudo, que esse poderá exercê-la em todas as circunstâncias. Distinguem-se aqui dois momentos: o da atribuição do poder jurisdicional e do pleno exercício de suas competências. A problemática central desse tópico permeia ambos os momentos citados.

Historicamente, a faculdade de aceitar ou não a jurisdição de um tribunal internacional remonta à prática da arbitragem. Os Estados se vinculavam ao instituto mencionado antes do fato, ou após esse, pelo chamado compromisso, no qual se estabelece o objeto da controvérsia, os árbitros, a indicação de seus poderes, as regras a serem seguidas e o compromisso de cumprir a sentença arbitral futura ${ }^{137}$.

Como resquício dessa prática, no nascer das jurisdições internacionais houve a formulação da cláusula facultativa de jurisdição obrigatória, ou cláusula Raul Fernandes, em homenagem ao diplomata brasileiro que a propôs no Comitê Consultivo de Juristas,

\footnotetext{
${ }^{133}$ KANT, Immanuel. Ideia de uma história universal de um ponto de vista cosmopolita. Organizado por Ricardo R. Terra. Traduzido por Rodrigo Naves e Ricardo R. Terra. 2. ed. São Paulo: Martins Fontes, 2004. p. 10.

${ }^{134}$ KELSEN, Hans. A paz pelo direito. Tradução de Lenita Ananias do Nascimento. São Paulo: WMF Martins Fontes, 2011. p. 13.

${ }^{135}$ HÖFFE, Otfried. A democracia no mundo de hoje. Trad. de Tito Lívio Cruz Romão. São Paulo: Martins Fontes, 2005. pp. 428-9.

${ }^{136}$ FERRAJOLI, Luigi. A soberania no mundo moderno: nascimento e crise do Estado nacional. Trad. de Carlo Coccioli e Márcio Lauria Filho. Revisão da tradução por Karina Jannini. São Paulo: Martins Fontes, 2002. pp. 54-5.

${ }^{137}$ ACCIOLY, Hildebrando. Tratado de Direito Internacional Público. São Paulo: Quartier Latin, 2009, v. III. p. 42.
} 
responsável por elaborar o Estatuto da Corte Permanente de Justiça Internacional, em 1920.

$\mathrm{Na}$ época, havia um embate entre aqueles que eram a favor da jurisdição obrigatória da CPJI e os que eram contrários a ela, notadamente, as grandes potências. A posição favorável prevaleceu no Conselho de Juristas, no entanto, não foi aprovada pelo Conselho da Liga das Nações. Para estabelecer o consenso que viabilizou o projeto do Estatuto da Corte Permanente de Justiça Internacional, o jurista e diplomata brasileiro propôs a fórmula da cláusula facultativa de jurisdição obrigatória ${ }^{138}$.

$\mathrm{O}$ art. 36 (2) é encontrado tanto no Estatuto da CPJI, quanto no da CIJ, dispondo que os Estados-partes podem declarar a qualquer momento, ipso facto e sem acordo especial, em relação a qualquer outro Estado que faça o mesmo, a "jurisdição" da Corte em todas as controvérsias jurídicas que tenham por objeto questões de Direito Internacional. Além de facultativa, a cláusula ainda comporta reservas ${ }^{139}$, podendo exigir a reciprocidade de um ou vários Estados por tempo determinado ${ }^{140}$.

CANÇADO TRINDADE afirma, ainda, que a cláusula facultativa é um resquício do Direito Internacional dos anos 20 e que não corresponde mais às demandas do contencioso internacional. O autor contextualiza com dados: até 2005 apenas 69 Estados se sujeitaram à jurisdição obrigatória da Corte Internacional de Justiça - o que representa cerca de um terço da comunidade internacional atual - e nessas ocasiões fizeram um uso distorcido, negando sua natureza e esvaziando sua eficácia ${ }^{141}$.

SHANY destaca que quase a totalidade das novas cortes e tribunais internacionais criados a partir da década de 50 foi estruturada de forma diversa da CIJ. E aponta como motivos para isso: a necessidade da inclusão de atores não Estatais na competência pessoal, a especialização na esfera da competência material, e a necessidade do exercício obrigatório da jurisdição, fato advindo da atestada ineficácia da referida cláusula

\footnotetext{
${ }^{138}$ CANÇADO TRINDADE, Antônio Augusto. International Law for Humankind: towards a New Just Gentium (II). General Course on Public International Law. RCADI, v. 315, 2005. p. 219.

139 "El Estado que presenta una Declaración tiene derecho de incluir em ella cualquier reserva, y muchas Declaraciones contienen reservas que disminuyen considerablemente la jurisdicción que se intenta conferir en el resto de la Declaración." (SORENSEN, Max (comp). Manual de Derecho Internacional Público. 11. ed. rev. e adiciones de Bernardo Sepúlveda. México: FCE, 2010. p. 655; BRIGGS, Herbert W.. Reservations to the acceptance of compulsory jurisdiction of the International Court of Justice. RCADI, 1958-I, t. 93. pp. 223-367).

${ }^{140}$ ESTATUTO DA CORTE INTERNACIONAL DE JUSTIÇA, art. 36 (3).

${ }^{141}$ CANÇADO TRINDADE, Antônio Augusto. Op. cit., 2005, p. 221.
} 
facultativa. O autor ilustra sua afirmação demonstrando que a procura pelas cortes regionais especializada foi significativamente maior do que pela corte universal de Haia ${ }^{142}$.

A constituição dos tribunais internacionais regionais especializados foi o ponto de partida para a retomada da ideia da jurisdição obrigatória. Nesse cenário, ROMANO afirma que a volta da "epifania kantiana” no pós-Segunda Guerra estimulou esse avanço nos planos regionais, o que resultou na adoção do novo paradigma compulsório da jurisdição internacional ${ }^{143}$.

A primeira instituição judicial internacional do pós-guerra ${ }^{144}$ a estabelecer a jurisdição obrigatória - no sentindo da submissão de todos os conflitos dentro de sua competência material (o direito comunitário) à análise de sua competência contenciosa foi a Corte Europeia de Justiça, ou Tribunal de Justiça da União Europeia (TJUE), estabelecido em $1952^{145}$. Assim, todo Estado que deseja fazer parte do bloco, no ato de adesão, reconhece a jurisdição e o pleno exercício das competências do Tribunal.

Seguindo os passos do modelo europeu, outros projetos regionais de integração também estabeleceram cortes e tribunais internacionais especializados com jurisdição obrigatória, como: a Corte Caribenha de Justiça ${ }^{146}$, o Tribunal de Justiça da Comunidade Andina $^{147}$, a Corte Centroamericana de Justiça ${ }^{148}$ e o Tribunal Permanente de Revisão do Mercosul (TPR) ${ }^{149}$.

No ramo dos Direitos Humanos essa evolução ocorreu mais tardiamente. Apesar de ter sido criada logo no final da década de 50, a Corte Europeia de Direitos Humanos só aderiu à jurisdição obrigatória no ano de 1998, com a entrada em vigor do Protocolo $\mathrm{n}$. $11^{150}$. Até então, só poderiam ser levados a juízo os Estados que expressamente declararam submissão à competência contenciosa da Corte ${ }^{151}$.

\footnotetext{
${ }^{142}$ SHANY, Yuval. No longer a weak department of power? Reflections on the Emergence of a New International Judiciary. European Journal of International Law, 2009, v. 20, n. 1, pp. 73-91, pp. 79-80, passim.

${ }^{143}$ ROMANO, Cesare P. R. The shift from the consensual to the Compulsory Paradigm in International Adjudication: elements of a Theory of Consent. Journal of International Law and Politics. New York University, 2007, v. 39, n. 791.

${ }^{144}$ A colocação do marco temporal é necessária, pois a primeira Corte Internacional a ter jurisdição obrigatória foi, na verdade, a Corte Centroamericana de Justiça, criada em 1907.

${ }^{145}$ BERGERÈS, Maurice-Christian. Contentieux communautaire. Paris: P.U.F., 1989. pp. 15-6, passim.

${ }^{146}$ ACORDO DE ESTABELECIMENTO DA CORTE CARIBENHA DE JUSTIÇA. Artigo XVI, Parte II.

${ }^{147}$ ESTATUTO DO TRIBUNAL DA COMUNIDADE ANDINA, art. $4^{\circ}$.

${ }^{148}$ ESTATUTO DA CORTE CENTROAMERICANA DE JUSTIÇA, art. $1^{\circ}$.

${ }^{149}$ PROTOCOLO DE OLIVOS, art. 33.

150 "Com o advento do Protocolo n. 11, ambas as cláusulas facultativas foram substituídas por obrigatórias os arts. 34 e 32, respectivamente. [...] Já o art. 32 prevê como obrigatória a competência jurisdicional da Corte Europeia.” (PIOVESAN, Flávia. Direitos Humanos e Justiça Internacional. Um estudo comparativo dos sistemas regionais europeu, interamericano e africano. São Paulo: Saraiva, 2006. p. 73).

${ }^{151}$ ROMANO, Cesare P. R. Op. cit., 1999, p. 811.
} 
Ainda sob a égide do paradigma do exercício facultativo da jurisdição encontra-se a Corte Interamericana de Direitos Humanos. O Pacto de San José da Costa Rica estabelece no seu art. 62 a necessidade, por parte dos Estados, de uma declaração de reconhecimento da competência contenciosa do referido órgão judicial ${ }^{152}$. Esse fato, além de ser um anacronismo, mina os objetivos e as finalidades do próprio Sistema Interamericano de Direitos Humanos, sem contar ser manifestamente contra a ratio da proteção internacional desses direitos ${ }^{153}$.

No caso da Corte Africana de Direitos Humanos e dos Povos a jurisdição é obrigatória, no entanto, a competência pessoal restringe a sua competência contenciosa. Isso se dá em função de que o Protocolo de Estabelecimento da Corte prevê que o acesso direto do indivíduo depende de prévio consentimento de cada Estado. Assim, se no polo ativo estiver a Comissão Africana de Direitos Humanos, outro Estado-parte ou qualquer outra organização intergovernamental africana, a jurisdição será exercida plenamente, mas se a petição for individual, dependerá da prévia aceitação do Estado requerido para iniciar os procedimentos ${ }^{154}$.

No âmbito universal, em 1994, destaca-se a criação da Organização Mundial do Comércio e seu sistema de solução de controvérsias ${ }^{155}$, o qual é dotado da jurisdição obrigatória do Órgão de Apelações. O funcionamento da estrutura de resolução de disputas no seio da OMC é considerado um dos grandes avanços do Direito Internacional Contemporâneo, justamente por seu caráter compulsório. Todo Estado que quiser fazer parte dessa importante organização internacional se submeterá, obrigatoriamente, aos mecanismos citados ${ }^{156}$.

\footnotetext{
${ }^{152}$ O Brasil reconheceu essa competência em 10 de dezembro de 1998 , no $50^{\circ}$ aniversário da Declaração Universal dos Direitos Humanos. (RAMOS, André de Carvalho. Teoria geral dos direitos humanos na ordem internacional. 2.ed. São Paulo: Saraiva, 2012. p. 103).

153 "The clause pertaining to the compulsory jurisdiction of international human rights tribunals constitutes, in my view, a fundamental clause (cláusula pétrea) of the international protection of the human being, which does not admit any restrictions other than those expressely provided for in the human rights treaties at issue." (CANÇADO TRINDADE, Antônio Augusto. International Law for Humankind: towards a New Just Gentium (II). General Course on Public International Law. RCADI, v. 315, 2005. p. 226).

${ }^{154}$ ENO, Robert Wundeh. The Jurisdiction of the African Court on Human and People's Rights. African Human Rights Law Journal, 2002, v. 2. pp. 223-33. p. 229.

155 "On doit signaler, en liaison avec le développment des techniques de contrôle, un cas très contemporain d'unification sinon d'intégration normative d'un ensemble de régles auparvant dispersées. Il s'agit de l'ensemble des normes relatives au droit international du commerce, aujourd 'hui regroupées par les accords de Marrakech sous l'égide de l'Organisation mondiale du commerce.La nouvelle construction et institutionelle établie par les accords de 1994 comporte une innovation importante ; elle réside précisément dans l'etablissement d'un système renforcé de contrôle du respect de leurs obligations par les États membres.[...]." (DUPUY, Pierre-Marie. Droit International Public. 9. ed. Paris: Dalloz, 2008. p. 555).

156 PETERSMAN, Ernest-Ulrich. The GATT/WTO Dispute Settlement System. International Law, International Organizations and Dispute Settlement. London, Hague, Boston: Kluwer Law International, 1997. p. 64.
} 
Considerado uma das maiores conquistas da humanidade, o Tribunal Penal Internacional é outro exemplo de órgão judicial internacional com jurisdição obrigatória e com aspiração de universalidade ${ }^{157}$. Além de exercer plenamente suas funções jurisdicionais em relação a indivíduos de Estados que ratificaram o Estatuto de Roma, esse documento ainda traz a possibilidade de, por delegação do Conselho de Segurança da ONU, estender sua jurisdição a Estados que não fazem parte da organização ${ }^{158}$.

Por fim, é importante lembrar que o Tribunal Internacional para o Direito do Mar (ITLOS) também possui jurisdição obrigatória sobre todas as disputas que versem sobre questões contidas na Convenção das Nações Unidas sobre o Direito do Mar e qualquer outro acordo que lhe atribuir esse poder ${ }^{159}$. O sistema de solução de controvérsias, contudo, prevê a escolha da parte entre o ITLOS e o Tribunal Especial Arbitral ${ }^{160}$. De qualquer modo, os conflitos terão necessariamente um desfecho jurídico.

Ficou demonstrado que o caminho natural da jurisdição no Direito Internacional Contemporâneo é o do paradigma obrigatório. Aos poucos, as cláusulas facultativas estão sendo ou suprimidas, como no caso da Corte Europeia de Direitos Humanos, ou virando verdadeiros elementos repulsores, como no caso da CIJ. O fato é que com a multiplicação dos tribunais internacionais, os sujeitos, quando lhes é permitido, escolherão a instituição que mais eficazmente atenderá à pretensão de resolver o conflito. Isso, contudo, tem gerado um desconforto - mais aparente que real - na doutrina jusinternacionalista.

1.2.2.2 Multiplicação de Jurisdições Internacionais: fragmentação ou pluralismo?

O fenômeno da multiplicação dos tribunais internacionais, desencadeado no fim da Guerra Fria, gerou uma série de preocupações na doutrina e jurisprudência internacional. $\mathrm{O}$ fato de existirem diversas jurisdições internacionais que se sobrepõem no âmbito das mesmas áreas do Direito Internacional, levantou questões sobre uma possível ameaça da unidade e coerência do sistema jurídico internacional.

\footnotetext{
157 KRESS, Claus. The International Criminal Court as a Turning Point in the History of International Criminal Justice. In: CASSESE, Antonio (editor in chief). The Oxford Companion to International Criminal Justice. New York: Oxford University Press, 2009. p. 143.

${ }^{158}$ Estatuto de Roma do Tribunal Penal Internacional, art. 13. Vide também: BERGSMO, Morten. O Regime Jurisdicional da Corte Internacional Criminal. In: CHOUKR, Fauzi Hassan; AMBOS, Kai (Orgs.). Tribunal Penal Internacional. São Paulo: Revista dos Tribunais, 2000. p. 229.

${ }^{159}$ ROCHA, Francisco Ozanan Gomes. The International Tribunal for the Law of the Sea. Hamburgo: Universitätspublikationen, 2001. p. 60.

${ }^{160}$ DUPUY, René-Jean; VIGNES, Daniel. A handbook on the new law of the sea. Dordrecht/Boston/ Lancaster: Martinus Nijhoff Publishers, 1991. p. 1369.
} 
Considerável parte dos jusinternacionalistas insiste em defender a existência de um processo fragmentador do Direito Internacional, o que estaria resultando no surgimento de regimes autossuficientes que regulariam as diferentes áreas desse Direito de forma independente. Esses "regimes" possuem cortes e tribunais internacionais que decidem os conflitos com base no seu próprio corpus jurídico, cujas decisões podem conflitar com a de outras cortes em uma mesma matéria, caso haja um conflito positivo de competências.

Em 2006 a Comissão de Direito Internacional (CDI) publicou um relatório sobre a Fragmentação do Direito Internacional: dificuldades surgidas da diversificação $e$ expansão do Direito Internacional" ${ }^{\text {161 }}$, no qual, em um primeiro momento, reafirmou a convicção sistêmica do DIP e, posteriormente, acabou por conceituar os "regimes especializados autossuficientes" e emprestar-lhes a sua legitimidade.

A primeira pergunta que deve ser feita quando se analisa essa questão é se realmente está em curso um processo de fragmentação do Direito Internacional. Em seguida, deve-se refletir sobre a forma como a multiplicação das jurisdições internacionais põe em risco a unidade e a coerência do Direito Internacional e em que medida isso não as reafirmaria. Para tanto, é fundamental que seja feita, primeiramente, uma reflexão sobre o que consiste a unidade e a coerência do DIP.

A questão da unidade no Direito Internacional é preocupação dos teóricos da disciplina desde seus fundadores. Assim, VITÓRIA já defendia a unidade do gênero humano em uma societas gentium que independia de uma organização internacional. Essa unidade era refletida no jus gentium, possuidor de um valor universal e independente do consentimento explícito de seus sujeitos. Um século mais tarde, SUAREZ resgata a ideia de Vitória e reafirma que todos os Estados estão sujeitos a essa civita perfecta e, portanto, são membros de uma sociedade universal regida pelo direito natural ${ }^{162}$.

No campo da Filosofia do Direito, BOBBIO, na sua Teoria do Ordenamento Jurídico $^{163}$ trata da unidade sob a perspectiva normativa nos sistemas jurídicos internos, levando sempre em conta a organização política dos Estados e a existência de poderes Executivo, Legislativo e Judiciário centrais, o que não existe no plano internacional. Isso, contudo, não implica na exclusão do uso analógico de suas constatações, ressalvadas as

\footnotetext{
${ }^{161}$ INTERNATIONAL LAW COMISSION. Fragmentation of International Law: difficulties arising from the diversification and expansion of International Law. Report of the Study Goup of the International Law Comission. Finalized by Martii Koskennieni. $58^{\text {th }}$ Session. Geneva, 3 July-11 August 2006.

${ }^{162}$ GUGGENHEIM, Paul. Contribution a l'histoire des sources du droit des gens. RCADI, 1958-II, t. 94. pp. 1-84. p. 22.

${ }^{163}$ BOBBIO, Norberto. Teoria do Ordenamento Jurídico. Trad. de Ari Marcelo Solon, prefácio de Celso Lafer, apresentação de Tércio Sampaio Ferraz Junior. São Paulo: EDIPRO, 2011.
} 
diferenças fundamentais entre ambos os ordenamentos e, assim, é merecedor de uma análise cuidadosa.

O autor começa sua análise sobre a unidade, reconhecendo que os ordenamentos jurídicos complexos possuem uma necessidade de regras de conduta tão acentuada que nenhum órgão ou poder seria capaz de satisfazê-la de forma independente. Por isso, o “poder supremo" usa de dois expedientes: a recepção de normas já prontas de outros ordenamentos e a delegação de poderes para que outros órgãos as produzam ${ }^{164}$.

A hipótese da delegação já pode ser excluída quando o Direito Internacional estiver em foco, uma vez que não há um poder supremo constituído na sociedade internacional para delegar funções para órgãos inferiores. Já a recepção não só é possível como já vem sendo utilizada pelos jusinternacionalistas. Um bom exemplo é o uso analógico de institutos dos direitos privados internos na prática jurídica internacional clássica.

Mais recentemente, DUPUY resgatou o tema da unidade do ordenamento jurídico internacional, analisando-o sob a perspectiva $\mathrm{e}$ as bases do Direito Internacional Contemporâneo. No referido estudo, o autor aborda a questão do ponto de vista da unidade formal e material da ordem jurídica internacional.

Por unidade formal entende-se aquela "estabelecida a partir da identidade dos sujeitos primários dessa ordem, que são os Estados, ser essencialmente ligada à utilização das mesmas regras secundárias de reconhecimento, produção e julgamento”. Já a unidade material é fruto das mudanças do Direito Internacional no pós-guerra e tem por base a Carta das Nações Unidas. Segundo o autor, essa pretende "refundar em partes a ordem internacional" não somente com o uso de "princípios jurídicos como também de valores éticos integrados às regras legalizadas”. DUPUY afirma, entretanto, que tal unidade ainda se encontra em um ambiente muito "fragmentário", o que a torna precária ${ }^{165}$.

No plano formal, a constatação de uma unidade no Direito Internacional é mais clara, uma vez que as fontes, sejam as tradicionais ou as contemporâneas, são reconhecidas como tais por toda sociedade internacional. Não há na prática internacional uma "fragmentação" das fontes do DIP, pois todo o seu conteúdo provém das mesmas regras secundárias de produção.

Por algum tempo, as regras de julgamento foram motivo de preocupação dos estudiosos do Direito das Gentes. Graças, contudo, ao trabalho da Comissão de Direito

${ }^{164}$ BOBBIO, Norberto. Teoria do Ordenamento Jurídico. Trad. de Ari Marcelo Solon, prefácio de Celso Lafer, apresentação de Tércio Sampaio Ferraz Junior. São Paulo: EDIPRO, 2011. p. 52.

${ }^{165}$ DUPUY, Pierra-Marie. L'unité de l'ordre juridique international: cours général de droit international public. RCADI, 2002, v. 297. p. 39. 
Internacional da ONU, nos seus Projetos de "Artigos sobre a Responsabilidade Internacional do Estado por Atos Ilícitos" 166 e de "Artigos sobre a Responsabilidade Internacional das Organizações internacionais" "167, houve uma sistematização dessas regras que antes estavam dispersas em normas consuetudinárias, o que - independentemente da discussão da natureza jurídica de um projeto de artigos da CDI - possibilitou uma unidade na questão.

Por fim, a questão mais polêmica no campo da unidade formal do DIP é a existência e identificação das regras de reconhecimento. Nesse rumo, HART define a existência dessas regras secundárias como o verdadeiro fundamento do sistema jurídico, exercendo o papel de "reconhecer" as normas primárias, ou de obrigação, atribuindo-lhes a validade $^{168}$.

O conceito de regra secundária de reconhecimento proposto por HART se assemelha ao da norma fundamental (Grundnorm) de KELSEN. Segundo esse, as normas encontram seu fundamento e validade no sistema jurídico com base em outras normas hierarquicamente superiores. Essa pirâmide, contudo, não é infinita, tendo no seu topo uma norma fundamental, pressuposta, cuja validade já não pode mais ser questionada. Assim, a Grundnorm é que "constitui a unidade de uma pluralidade de normas enquanto representa o fundamento da validade" de todo o ordenamento jurídico ${ }^{169}$.

Analisados os conceitos, impõe-se a pergunta: existe uma regra secundária de reconhecimento, ou norma fundamental, no sistema jurídico do Direito Internacional? Para muitos doutrinadores a resposta para essa questão é o instituto do jus cogens, também conhecido como normas imperativas, ou peremptórias, de direito internacional geral, de acordo com a sua primeira definição constante no art. 53 de um documento jurídico internacional apresentado na Convenção de Viena sobre o Direito dos Tratados, de 1969.

\footnotetext{
${ }^{166}$ INTERNATIONAL LAW COMMISSION. Draft articles on responsibility of states for internationally wrongful acts, with commentaries. Yearbook of the International Law Commission, 2001, v. II, Part Two. 167 INTERNATIONAL LAW COMMISSION. Draft articles on responsibility of international organizations, with commentaries. Yearbook of the International Law Commission, 2011, v. II, Part Two. 168 "Onde quer que essa norma de reconhecimento seja aceita, tanto os indivíduos quanto as autoridades públicas dispõem de critérios válidos para a identificação das normas primárias de obrigação. Os critérios assim disponibilizados podem, como vimos, assumir qualquer uma, ou mais de uma, dentre diversas formas; incluem-se entre estas a referência a um texto autorizado; a um ato legislativo; à prática consuetudinária; a declarações gerais de pessoas específicas; ou, em casos particulares, a decisões judiciais anteriores sobre casos específicos [...].” (HART, H. L. A. O conceito de direito. Pós-escrito organizado por Penelope A. Bullroch e Joseph Raz. Trad. de Antônio Oliveira Sette-Câmara. Revisão da tradução de Marcelo Brandão Cipolla. Revisão técnica de Luiz Vergílio Dalla-Rosa. São Paulo: WMF Martins Fontes, 2009. p. 130).

${ }^{169}$ KELSEN, Hans. Teoria pura do Direito. Trad. de João Baptista Machado. 8. ed. São Paulo: WMF Martins Fontes, 2009. p. 217.
} 
Alguns problemas, no entanto, se impõem sobre tal afirmação como, por exemplo, a dificuldade na definição do conteúdo e na identificação de tais normas no ordenamento jurídico internacional. Além disso, muito se questiona sobre seu fundamento em uma sociedade internacional em transição de paradigmas.

Nesse contexto, insere-se a discussão sobre a unidade material do Direito Internacional que, de acordo com DUPUY, reside no conteúdo substancial da normatividade internacional ${ }^{170}$ e se baseia nas seguintes premissas: i) a Carta das Nações Unidas como uma Constituição; ii) a possibilidade da existência de uma comunidade internacional; iii) o papel do jus cogens; iv) o alargamento da problemática das perspectivas da manutenção da paz; e v) a responsabilidade internacional pela violação das normas imperativas de Direito Internacional Geral ${ }^{171}$.

$\mathrm{O}$ autor francês considera, portanto, a unidade material da ordem jurídica internacional na existência de um "tipo de legalidade superior, caracterizada pela sua inderrogabilidade universal" e conclui que esta se trata de uma "aposta política traduzida em direito positivo" ${ }^{172}$.

Paralelamente, CANÇADO TRINDADE justifica a unidade do direito internacional, no plano material, na existência de uma consciência humana universal, sem a qual o ser humano seria completamente sujeito à opressão e atrocidades ${ }^{173}$. Segundo o autor:

\footnotetext{
Em última análise, é a consciência coletiva do que é juridicamente necessário (opinio juris communis necessitatis) que tem levado à criação da normativa internacional orientada por valores objetivos superiores. Trata-se de um Direito, mais do que vonluntário, necessário. É da consciência jurídica universal que germinou o jus cogens, que, por sua vez, veio dar um conteúdo ético ao Direito Internacional contemporâneo ${ }^{174}$.
}

Dessa maneira, no pensamento citado, a regra secundária de reconhecimento do sistema jurídico internacional não é o jus cogens, pois esse também encontra sua validade em um valor superior: o da consciência jurídica universal. Assim, a unidade formal se funde com a material que, muito embora esteja claramente perceptível desde o fim da Guerra Fria, ainda está em processo de construção e consolidação.

\footnotetext{
${ }^{170}$ DUPUY, Pierre- Marie. L'unité de l'ordre juridique international: cours général de droit international public. RCADI, 2002, v. 297. p. 207.

${ }_{171}$ Id., ibid., pp.215- 399, passim.

${ }^{172}$ Id., ibid., p. 213.

${ }^{173}$ CANÇADO TRINDADE, Antonio Augusto. International Law for Humankind: towards a New Jus Gentium (I). General Course on Public International Law. RCADI, 2005, v. 316. p. 182.

174 CANÇADO TRINDADE, Antonio Augusto. O Direito Internacional em um mundo em transformação. Rio de Janeiro: Renovar, 2002. p. 1088.
} 
Por fim, restou demonstrado nas obras analisadas que o sistema jurídico internacional possui unidade tanto no plano formal quanto material. Para sua plena realização no meio social que pretende regular, esse também deve se apresentar coerente.

O problema da coerência de um sistema jurídico diz respeito a sua qualidade essencial de "totalidade ordenada"" Assim, há necessidade de que sejam garantidas a certeza e a justiça na aplicação de suas normas. Nesse contexto, BOBBIO propõe a questão:

\begin{abstract}
Entendemos por "sistema" uma totalidade ordenada, isto é, um conjunto de entes dentre os quais existe uma certa ordem. Para que se possa falar de ordem, é necessário que os entes constitutivos não estejam em relação apenas com o todo, senão que também estejam em coerência entre eles. Pois bem, quando nos perguntamos se um ordenamento jurídico constitui um sistema, perguntamos se as normas que o compõem estão em relação de coerência entre elas, bem como quais condições tornam possível essa relação ${ }^{176}$.
\end{abstract}

A existência, portanto, de duas regras plenamente válidas, mas contraditórias, em um ordenamento jurídico é perfeitamente possível. Tem-se, nesse caso, as chamadas antinomias. De fato, são condições para a sua existência que as duas normas antinômicas estejam inseridas no mesmo ordenamento jurídico e que tenham o mesmo âmbito de validade $^{177}$.

Demonstradas conceitualmente tanto a unidade quanto a coerência do sistema jurídico internacional, importa agora responder às questões feitas anteriormente. A primeira, quanto a se realmente está em curso um processo de fragmentação do Direito Internacional, a resposta negativa pode ser encontrada no mesmo relatório que atenta para esse perigo, quando a CDI indicou que as antinomias causadas por conflitos de normas internacionais deveriam ser resolvidas sob a égide do princípio da unidade sistêmica, harmonizando as regras conflitantes no contexto do ordenamento ${ }^{178}$. Como já analisado, se é assumida a posição do DIP como sistema jurídico, uníssono e coerente, inadmite-se, portanto, a posição fragmentária.

A própria terminologia "regimes especializados autocontidos" empregada por aqueles que entendem estar em curso um processo de fragmentação, é conceitualmente

\footnotetext{
${ }^{175}$ BOBBIO, Norberto. Teoria do Ordenamento Jurídico. Trad. de Ari Marcelo Solon, prefácio de Celso Lafer, apresentação de Tércio Sampaio Ferraz Junior. São Paulo: Edipro, 2011. p. 79.

${ }^{176}$ Id., ibid., p. 79-80.

${ }^{177}$ Id., ibid., p. 92-3.

${ }^{178}$ INTERNATIONAL LAW COMISSION. Fragmentation of International Law: difficulties arising from the diversification and expansion of International Law. Report of the Study Goup of the International Law Comission. Finalized by Martii Koskennieni. $58^{\text {th }}$ Session. Geneva, 3 July-11 August 2006. § 36 .
} 
equivocada e deriva de teorias políticas. Ora, se é reconhecido que o Direito Internacional configura um sistema jurídico ${ }^{179}$, sua especialização possibilitou a edificação de ramos, ou subsistemas, ou microsistemas ${ }^{180}$. Essas denominações atentam para a especificidade de determinadas áreas, mas, ao mesmo tempo, indicam sua pertença a um todo, possibilitada pelo vínculo da unidade ${ }^{181}$.

Dessa forma, é possível concluir que a chamada "fragmentação" não ameaça a unidade e a coerência da ordem jurídica internacional. O próprio uso do termo parece incoerente, pois o que se testemunha, diante do exposto, é um verdadeiro pluralismo endógeno $^{182}$ do sistema jurídico internacional. O direito internacional, portanto, sai fortalecido dessa problemática, e imbuído de uma tarefa essencial: a de coordenação da sociedade internacional plural que evolui, garantindo a ordem e a justiça ao enfatizar a coerência de suas normas ${ }^{183}$.

Constata-se, então, que não há um processo de fragmentação do Direito Internacional em curso, o que leva a concluir que a multiplicação dos tribunais e cortes internacionais também não é danosa ao sistema jurídico internacional. O fato de haver conflitos de jurisdição e competência entre os vários órgãos judiciais internacionais não

\footnotetext{
179 "International law is a legal system. Its rules and principles (i.e. its norms) act in relation to and should be interpreted against the background of other rules and principles. As a legal system, international law is not a random collection of such norms. There are meaingful relationships between them. Norms may thus exist at higher and lower hierarchical levels, thein formulation may involve greater or lesser generality and specificity and their validity may date back to earlier or later moments in time." (INTERNATIONAL LAW COMISSION. Fragmentation of International Law: difficulties arising from the diversification and expansion of International Law. Report of the Study Goup of the International Law Comission. Finalized by Martii Koskennieni. $58^{\text {th }}$ Session. Geneva, 3 July-11 August 2006. $§ 1^{\circ}$ ). Vide também: BENVENISTI, Eyal. The conception of International Law as a Legal System. Tel Aviv University Law School: Tel Aviv University Law Faculty Papers. Year 2008. p. 83.

${ }^{180}$ MENEZES, Wagner. Tribunais Internacionais: jurisdição e competência. São Paulo : Saraiva, 2013. p. 312 .

${ }^{181}$ Quanto à questão do uso do vocábulo "regimes especializados autossuficientes" ou no inglês "self contained regimes", Dupuy endereça a crítica: "Toutefois, la notion de "régime autosuffisant "mérite qu'on poursuive son analyse critique tant elle est symptomatique d'une vision fragmentaire et parcellisée du droit international partagée par trop d'auteurs, dans laquelle, faute d'une claire perception de ce que constitue un ordre juridique et l'ordre juridique international en particulier, ces auteurs se perdent aujourd'hui dans la contemplation de régimes qu'ils croient aussi clos sur eux-mêmes qu'ils le sont trop souvent eux-mêmes sur leur propre spécialité. Ainsi, bien qu'évacué des travaux sur la responsabilité, on voit cependant émerger, tel un monstre du Loch Ness, le self-contained regime. Il montre sa physionomie, par excellence originale, à l'occasion de l'analyse de domaines spécifiques du droit, notamment parmi ceux ayant connu des développements normatifs récents. Contemplant la multiplication des régimes particuliers établis le plus souvent par voie de convention, leurs étroits spécialistes délaissent bien souvent l'analyse des rapports que ces régimes entretiennent avec le droit international général en les qualifiant non plus de systèmes sui generis, car ces auteurs s'expriment désormais le plus souvent en anglais, mais de 'self-contained regimes!' (DUPUY, Pierre-Marie. L'unité de l'ordre juridique international : cours général de droi international public. RCADI, 2002, v. 297. p. 436).

${ }_{182}$ MENEZES, Wagner. Op. cit., 2013, p. 313.

${ }^{183}$ AMARAL JÚNIOR, Alberto do. Curso de Direito Internacional Público. 2. ed. São Paulo: Atlas, 2011. p. 155
} 
significa uma desestruturação do DIP, mas sim um percalço, facilmente transponível, de sua própria evolução.

Na Academia de Direito Internacional de Haia, CHARNEY refletiu sobre o tema da possível ameaça ao Direito Internacional pelos múltiplos tribunais e cortes internacionais $^{184}$. Ao final de um estudo comparativo sobre a atuação de determinadas instituições judiciais em temas comuns, o autor chegou à conclusão de que há na atividade jurisdicional internacional um entendimento coerente do DIP e de seus fundamentos, o que resguarda sua unidade ${ }^{185}$.

ABI-SAAB, por sua vez, defende que o sistema jurídico internacional possui uma unidade de pensamento jurídico num ambiente de múltiplas ordens jurídicas. Como consequência, há uma diversidade de tribunais que têm em comum o fato de pertencerem ao mesmo sistema jurídico, e no seu seio formam uma rede encarregada de exercer uma importante função no plano internacional: a função judicial ou adjudicatória. Cada órgão judicial é criado na especificação e densidade do ramo do DIP no qual vai atuar, o que não significa que atuará isoladamente ${ }^{186}$.

Outro entendimento positivo do fenômeno é o de CANÇADO TRINDADE, para quem a multiplicação das cortes e tribunais internacionais é algo extremamente benéfico ao Direito Internacional, uma vez que amplia as possibilidades de acesso à justiça internacional e maximiza sua vocação pacificadora. $\mathrm{O}$ autor aponta que essas instituições não estão organizadas em um plano hierárquico, mas de coordenação e

\footnotetext{
${ }^{184}$ CHARNEY, Jonathan I. Is international law threatened by multiple international tribunals? RCADI, 1998, t. 271. pp.101-382.

185 "This lecture demonstrates that in several core areas of international law the different international tribunals of the late twentieth century do share a coherent understanding of that law. Although differences exist, these tribunals are clearly engaged in the same dialectic. The fundamentals of general international law remain the same regardless of which tribunal is deciding the issue. This conclusion is probably also applicable to other areas of international law and other tribunals that were not studied. One could predict that this past experience will continue into the future. Certainly, the situation is not perfect and improvements could be prescribed." (Id., ibid., p. 347).

186 "As mentioned earlier, the prodigious development of international law in the last few decades, reflected in the greater density, complexity, and diversity of its normative content, has also led to the multiplication of specialized mechanisms of implementation, including tribunals. This confirms what I consider to be a law of legal physics, which can be formulated as follows: "To each level of normative density, there corresponds a level of institutional density necessary to sustain the norms" (i.e., which makes it possible to manage and apply them).In other words, in these circumstances, the multiplication of specialized tribunals is, by itself, a healthy phenomenon. Its description by the term "proliferation," with its negative connotations, is misleading. Of course, proliferation is extremely dangerous when we speak of lethal weapons of mass destruction. But it is a totally different matter when we speak of tribunals or other law-determining agencies in a system that has notoriously suffered, throughout its existence, from the dearth (not to say lack) of objective determinations." (ABI-SAAB, Georges. Fragmentation of unification: some concluding remarks. Journal of International Law and Politics. New York University, 1999, v. 31, pp. 919-33. p. 925).
} 
complementaridade. Além disso, o juiz da CIJ enfatiza a importância desses órgãos na criação e aperfeiçoamento do DIP pela jurisprudência internacional ${ }^{187}$.

Por fim, TREVES considera a multiplicação das cortes internacionais como algo "prematuro e provavelmente exagerado", uma vez que esse fato nada mais é que um indício da crescente importância desse mecanismo de solução de controvérsias na evolução do Direito Internacional ${ }^{188}$.

Fica demonstrado, portanto, que a multiplicação das jurisdições internacionais não é consequência e, muito menos, a causa de um alegado processo de fragmentação do Direito Internacional. Ao contrário, esses órgãos reforçam a unidade e a coerência do sistema jurídico internacional na sua atuação jurisdicional e ampliam as hipóteses de acesso à justiça no plano internacional. Isso reflete positivamente na construção do Direito Internacional e na realização do princípio da solução pacífica de controvérsias.

\subsubsection{A jurisprudência internacional e o direito internacional contemporâneo}

A jurisprudência internacional é, consoante CASELLA, a "tradução dos princípios na prática: são elementos da construção do direito internacional" ${ }^{\text {189 }}$. Como referido no tópico anterior, a jurisdição internacional possui duas funções primordiais: a de resolver os conflitos que lhe são submetidos e a de consolidar o Direito Internacional. Combinadas, as duas funções resultam na produção de uma das mais importantes fontes do DIP contemporâneo: a jurisprudência internacional.

No art. 38, "d" do Estatuto da Corte Internacional de Justiça ${ }^{190}$, a jurisdição internacional passou de "fonte auxiliar" para protagonista de importantes construções normativas contemporâneas e, na era da multiplicação dos tribunais, tem lugar de prestígio no sistema jurídico internacional ${ }^{191}$.

\footnotetext{
187 CANÇADO TRINDADE, Antônio Augusto. El ejercicio de la Función Judicial Internacional. Memorias de la Corte Interamericana de Derechos Humanos. Belo Horizonte: Del Rey, 2011. p. 195.

${ }^{188}$ TREVES, Tulio. Diritto Internazionale. Problemi Fondamentali. Milano: Giuffrè Editore, 2005. p. 643.

${ }^{189}$ CASELLA, Paulo Borba. Fundamentos do Direito Internacional Pós-Moderno. São Paulo: Quartier Latin, 2008. p. 196.

190 “Art. 38: 1- A Corte, cuja função é decidir de acordo com o Direito Internacional as controvérsias que lhe forem submetidas, aplicará: [...] d) Sob ressalva do art. 59, as decisões judiciárias e a doutrina dos juristas mais qualificados das diferentes nações, como meio auxiliar para a determinação das regras de direito." (ESTATUTO DA CORTE INTERNACIONAL DE JUSTIÇA, art. 38, alínea “d”).

191 "A construção do direito internacional, no contexto pós-moderno, tem marcos intrinsecamente internacionais específicos, e estes constituem as ferramentas básicas de trabalho para os profissionais da área: ninguém pode estudar e pretender conhecer direito internacional sem manejar as bases da jurisprudência internacional (especialmente da Corte Internacional de Justiça, sua predecessora, a Corte Permanente de
} 
O Estatuto da Corte Internacional de Justiça é uma herança do antigo Estatuto da Corte Permanente de Justiça Internacional, que foi elaborado na década de 20 do século passado. À época, FINCH explica que a inclusão das decisões de tribunais internacionais no rol do art. 38 foi uma tentativa do comitê de juristas de prevenir o non-liquet, em razão da aparente incompletude do sistema jurídico internacional então vigente ${ }^{192}$. A esse respeito, ACCIOLY, NASCIMENTO E SILVA e CASELLA enfatizam que se esse documento fosse redigido nos dias atuais, a jurisprudência internacional certamente receberia lugar de destaque no rol das fontes ${ }^{193}$.

A redação do referido dispositivo contempla a expressão "decisões judiciais", o que acaba por empregar-lhe um sentido amplo, podendo ser inclusos nesse rol aqueles dispositivos de outros tribunais internacionais judiciais ou arbitrais e até mesmo de cortes nacionais $^{194}$.

De acordo com DIEZ DE VELASCO, a jurisprudência ajuda o juiz internacional na interpretação e serve como meio de prova da existência das normas. $\mathrm{O}$ autor, entretanto, não concorda com a afirmação de que aquela seria a fonte formal do Direito Internacional, mas reconhece que o florescimento dos tribunais internacionais contribuiu significativamente para a sua formação ${ }^{195}$.

A questão da negação de seu caráter de fonte primária reside no fato de o art. 59 do mesmo ECJI ${ }^{196}$ restringir o efeito das decisões da Corte às partes da controvérsia. A CIJ, entretanto, usa constantemente sua jurisprudência para decidir os casos, o que demonstra a extensão de seus enunciados para além do enunciado no dispositivo supra. SHAW enfatiza que em alguns casos há referência direta às sentenças passadas para fundamentar novas decisões, como nos casos Nottebohm e Pescarias Anglo-Norueguesas, e em outros, a Corte as utiliza como ponto de partida para a nova discussão, como no caso Camarões vs. Nigéria ${ }^{197}$.

Justiça Internacional e a Corte Permanente de Arbitragem).” (ACCIOLY, Hildebrando; NASCIMENTO E SILVA, G. E.; CASEllA, Paulo Borba. Manual de Direito Internacional Público. 17. ed. São Paulo: Saraiva, 2009. p. 158.

${ }^{192}$ FINCH, George A. Les sources modernes du droit international. RCADI, 1935-III, t. 53. pp. 531-629. p. 624.

${ }^{193}$ ACCIOLY, Hildebrando; NASCIMENTO E SILVA, G. E.; CASELLA, Paulo Borba. Op. cit., 2009. pp. 156-7.

${ }_{194}^{19}$ SHAW, Malcolm N. International Law. $6^{\text {th }}$ ed. Cambridge: Cambridge University Press, 2010. p. 113.

${ }^{195}$ VELASCO, Manuel Diez de. Instituiciones de Derecho Internacional Público. 15. ed. Madrid: Tecnos, 2005. p. 126.

196 ESTATUTO DA CORTE INTERNACIONAL DE JUSTIÇA, art. 59: "A decisão da Corte só será obrigatória para as partes litigantes e a respeito do caso em questão."

${ }^{197}$ SHAW, Malcolm N..Op. cit., 2010, p. 110. 
Essa prática encontra certa resistência na doutrina ${ }^{198}$ sob o argumento de que o sistema jurídico internacional não foi concebido como um sistema da Common Law, no qual vige a doutrina do stare decisis, ou seja, a vinculação do juiz aos precedentes na decisão do caso concreto ${ }^{199}$. A prática nos tribunais internacionais, entretanto, mostra não uma necessária vinculação, mas sim um uso ${ }^{200}$ em recorrer a casos já decididos.

A jurisprudência internacional, portanto, atua na construção do Direito Internacional Contemporâneo com a formação de sua normatividade, na medida em que, de fato, dá origem a normas gerais ${ }^{201}$. Esse trabalho resulta no reconhecimento de normas consuetudinárias, na composição do rol das normas imperativas de Direito Internacional Geral (jus cogens) $)^{202}$, na formulação de regras processuais ${ }^{203}$ e na cristalização de princípios do ordenamento jurídico internacional ${ }^{204}$.

No entendimento de WEIL, a legitimidade do juiz internacional para a criação de novas normas internacionais repousa em reconhecê-las como um costume preexistente. $\mathrm{O}$ autor ilustra sua afirmação com os casos de delimitação marítima, nos quais a CIJ se opôs ao direito convencional, alegando a existência de uma norma consuetudinária contrária que, na realidade, foi de sua própria criação ${ }^{205}$.

$\mathrm{O}$ mesmo acontece quando as jurisdições internacionais reconhecem determinadas normas como integrantes do rol do jus cogens. Nesse campo, o destaque é para a Corte

\footnotetext{
${ }^{198}$ ZIMMERMAN, Andreas; TOMUSCHAT, Christian; OELLERS-FRAHM, Karin (Edit.). The Statue of the International Court of Justice. A commentary. New York: Oxford University Press, 2006. p. 784.

199 "In simple terms the doctrine of judicial precedent, also known as the doctrine of 'stare decisis' ("let the decision stand'), means that when a judge comes today to try a case he must proceed by analogy and always look back to see how previous judges have dealt with previous cases (known as precedents) which have involved similar facts in that branch of law. [...].” (KINDER-GEST, Patrícia. Manuel de Droit Anglais. I. Institutions Politiques et Judiciaires. Paris: L.G.D.J., 1989. p. 198, grifo da autora).

${ }^{200}$ SOARES, Guido Fernandes Silva. Curso de Direito Internacional Público. São Paulo: Atlas, 2002, v. 1. p. 98.

201 “Confrontée à des situations rendues souvent difficiles par l'evolution rapide des règles applicables ou par les limites qu'imposaient à sa juridiction les termes dans lesquels elle était reconnue, la Cour internationale de Justice, en plusieurs occasions, n'as pas hesite à s'appuyer sur l'énonciation de règles générales. Or Il n'est pas toujours évident de les qualifier de coutumes internationales, tant, Du moins, que l'on s'en tient à la acception qu'en donne l'article 38 de son Statut. Elle affirme ainsi l'importance de son role dans la formation de ces règles." (DUPUY, Pierre-Marie. Le juge et la règle générale. Revue Générale de Droit International Public, 1989, pp. 569-98. p. 570).

${ }^{202}$ Convenção de Viena sobre o Direito dos Tratados de 1969, art. 66 (KOVACS, Péter. Developpement et limites de la jurisprudence en droit international. In: SOCIETÉ FRANÇAISE POUR LE DROIT INTERNATIONAL. La jurisdictionnalisation du Droit International. Colloque de Lille. Paris: Pedone, 2003. pp. 269-341. p. 277).

${ }^{203}$ SORENSEN, Max. Manual de Derecho Internacional Público. 11. ed. rev. e adiciones de Bernardo Sepúlveda. México: FCE, 2010. p. 179. Vide também: SALVIOLI, Gabriele. La jurisprudence de la Cour permanente de justice internationale. RCADI, 1926-II, t. 12. pp. 1-114).

${ }^{204}$ MENEZES, Wagner. Tribunais Internacionais: jurisdição e competência. São Paulo : Saraiva, 2013. p. 241 .

${ }^{205}$ WEIL, Prosper. Le droit international en quete de son identité: cours général de Droit International Public. RCADI, 1992-VI, t. 237. pp. 9-370. p. 143.
} 
Interamericana de Direitos Humanos, pois, certamente, foi a que reconheceu o caráter jus cogens de várias normas e esclareceu sua correlação com as correspondentes obrigações erga omnes. Os motivos apontados para essa intensa atividade de reconhecimento são ainda discutidos, contudo, são dois os mais recorrentes: um possível consenso regional interamericano quanto ao caráter absoluto de determinadas normas, e a influência do pensamento do juiz Antônio Augusto Cançado Trindade, que por uma década presidiu a referida Corte, período em que produziu boa parte de seu material doutrinário ${ }^{206}$.

Outra discussão contemporânea sobre o tema aqui analisado é o fenômeno chamado “fertilização cruzada" ou "julgamentos cruzados". Trata-se do resultado da multiplicação dos tribunais internacionais que, ao decidirem seus casos, embasam-se na jurisprudência de suas semelhantes. De acordo com BROWN, há uma troca de experiência entre os órgãos judiciais internacionais, especialmente no que concerne a procedimentos e remédios, o que leva a uma crescente harmonização na atuação judiciária internacional ${ }^{207}$.

Já RAMOS percebe na "fertilização cruzada" uma alternativa para o conflito existente entre os tribunais de integração econômica e as cortes regionais de Direitos Humanos. O autor justifica que o Direito Internacional dos Direitos Humanos é dotado de normas com redação genérica "contendo valores muitas vezes conflitantes”. Desse modo,

\footnotetext{
206 “D’un point de vue quantitatif, force est de constater un véritable foisonnement des références au jus cogens dans les arrêts comme dans les avis de la Cour interaméricaine, à tel point que l'on peut avancer que c'est certainement le tribunal qui a le plus fait pour la consolidation de cette notion dans le droit international (I). D’un point de vue qualitatif, cette jurisprudence accuse certains traits spécifiques, non seulement en raison de la forte empreinte du juge Cançado Trindade, mais également en raison de la réhabilitation de la notion de crime d'Etat qui semble l'orienter vers une pénalisation de la responsabilité étatique pour les graves violations des droits de l'homme (II).” (MAIA, Catherine. Le Jus Cogens dans la Jurisprudence de la Cour Interamericaine des Droits de l'homme. In: HENNEBEL, Ludovic; TIGROUDJA, Hélène. Les particularisme interamericain des droits de l'homme. En l'honneur du $40^{\mathrm{e}}$ anniversaire de la Convention Américaine des droit de l’homme. Paris: Pedone, 2009. p. 278).

207 "The emergence of commonalities is significant because it was unclear whether the proliferation of international tribunals would give rise to the convergence in their approach to procedure and remedies. Moreover, there was the potential for the emergence of inconsistent approaches to result, because international courts and tribunals derive their jurisdiction and competence from their own constitutive instruments and rules of procedure that are not expressed in identical terms. Further, different international tribunals have different functions, which could lead to variations in approach. Nonetheless, the case law of international courts and tribunals reveals convergent rather than divergent practices on these issues. It demonstrates that while international courts seek to apply the provisions of their statutes and rules of procedure, these instruments do not foresee every procedural issue that may arise in the course of international proceedings. Additionally, most are silent on the nature of the remedies that can be awarded. Where lacunae exist in these instruments and where their provisions might be interpreted and applied in various ways, international courts often turn for guidance to the practice of other international tribunals, and many examples can be cited to illustrate this." (BROWN, Chester. The cross-fertilization of principles relating to procedure and remedies in the Jurisprudence of International Courts and Tribunals. Loyola of Los Angeles International and Comparative Law Review, 2008, v. 30, pp. 219-245. p. 222).
} 
alega que um tribunal pode encontrar importantes subsídios hermenêuticos na formação da jurisprudência de outro tribunal ${ }^{208}$.

No mesmo sentido, TEITEL e HOWSE defendem um posicionamento que reside na constatação de que a multiplicação das cortes gerou um diálogo interpretativo entre as várias instituições - nomeado por eles de cross-judging - o que, de certa forma, leva à concepção de uma ordem internacional descentralizada, mas coerente ${ }^{209}$.

Pode-se concluir, então, que a jurisdicionalização do Direito Internacional produziu não só uma variedade de novos tribunais internacionais, como, também, mudou as estruturas normativas do próprio DIP ao se firmarem como verdadeiras autoridades legislativas $^{210}$. Consequentemente, o exercício da jurisdição internacional pelas várias instituições possuidoras desse poder tem como principal produto a jurisprudência internacional, a qual, na forma de decisões, constrói, renova e fortalece o sistema jurídico internacional.

\subsection{A RELAÇÃO ENTRE OS DIREITOS INTERNO E O DIREITO INTERNACIONAL CONTEMPORÂNEO E OS REFLEXOS DA JURISDICIONALIZAÇÃO}

A jurisdicionalização do Direito Internacional, como demonstrado anteriormente, provocou mudanças normativas e institucionais na sociedade internacional contemporânea. Essas transformações ocorrem num contexto em que o Direito Internacional Clássico dá lugar a um Direito Internacional Contemporâneo que convive com as tensões de uma fase de transição: de um lado o Estado como um importante sujeito dotado da blindagem defasada, contudo ainda presente - da soberania; do outro um corpo jurídico rico em temas, instituições e cada vez mais autocompreendido.

A coexistência pacífica entre os Estados está dando lugar a relações de cooperação e solidariedade que transformam o fundamento, os sujeitos e as fontes do DIP. O Estado passa a dividir a subjetividade internacional com as organizações internacionais e os indivíduos. As fontes clássicas agora são complementadas - quando não orientadas ou

\footnotetext{
${ }^{208}$ RAMOS, André de Carvalho. Direitos humanos na integração econômica. Análise comparativa da proteção de direitos humanos e conflitos jurisdicionais na União Europeia e Mercosul. Rio de Janeiro: Renovar, 2008. p. 458.

${ }^{209}$ TEITEL, Ruti; HOWSE, Robert. Cross-Judging: tribunalization in a fragmented but interconnected global order. New York University International Law and Politics Journal. 2009, v. 41. pp. 959-90. p. 988-990, passim.

${ }^{210}$ HAMBRO, Edvard. The Jurisdiction of International Court of Justice. RCADI, 1950-I, t. 76. pp. 121216. p. 126.
} 
confrontadas - por princípios, resoluções das OIs, atos unilaterais, jus cogens, obrigações erga omnes, soft law e pela jurisprudência dos tribunais internacionais.

Como restou claro nos tópicos anteriores, a jurisdicionalização do Direito Internacional aumentou o grau de monitoramento do cumprimento das obrigações internacionais. Em consequência foram constituídos tribunais internacionais que possuem o poder de proferir atos próprios do exercício de sua jurisdição que, além de vincularem as partes da lide - e em alguns casos até outros $^{211}$ - a obrigações diversas, demandam, na maioria das vezes, atos dos direitos internos para serem plenamente efetivos ${ }^{212}$.

Da mesma maneira, a relação com os direitos internos não poderia permanecer a mesma. De fato, o DIP contemporâneo aumentou significativamente sua esfera de atuação e, hoje, disciplina e monitora o que antigamente era de domínio, jurisdição ou matéria reservada dos Estados ${ }^{213}$. Muito embora o art. $2^{\circ}$ da Carta das Nações Unidas estabeleça no seu inciso $7^{\circ}$ que nenhum dos dispositivos da referida Carta deverá autorizar a ONU a interferir em assuntos que dependam "essencialmente da jurisdição de qualquer Estado", a questão do domínio reservado vem sofrendo constantes relativizações ${ }^{214}$.

A revisão desse conceito é um dos efeitos da institucionalização e jurisdicionalização do Direito Internacional. No pós-Segunda Guerra Mundial, as Organizações Internacionais passaram a disciplinar - se não legislar ativamente - questões consideradas como de "legítimo interesse internacional". Essa expressão foi o principal argumento para restringir o poder dos Estados no que tange a temas sensíveis, como direitos humanos, meio ambiente e comércio internacional ${ }^{215}$.

Já em 1946, um ano após a entrada em vigor da Carta das Nações Unidas, o Conselho de Segurança e a Assembleia Geral discutiram o caso que ficou conhecido como “caso espanhol”. Nessa oportunidade, ficou claro que as delegações dos países-membros se

\footnotetext{
${ }^{211}$ Como no caso de obrigações erga omnes e de normas de jus cogens.

212 "Contudo, o alargamento normativo gerou uma crescente complexidade das normas internacionais, com obrigações cada vez mais invasivas e reguladoras das mais diversas facetas da vida social doméstica. Ao aceitar tais obrigações, os Estados - ao mesmo tempo - exigiram um sistema que assegurasse que os demais Estados parceiros não iriam adotar a visão tradicional vista acima. Assim, a desconfiança entre os Estados fez nascer uma aceitação galopante de sistemas de solução de controvérsias, nos quais se obtém uma interpretação internacionalista das normas." (RAMOS, André de Carvalho. Pluralidade das ordens jurídicas: a relação do direito brasileiro com o direito internacional. Curitiba: Juruá, 2012. p. 20).

${ }_{213}$ ' $D$ 'après la dite notion 'juridique', la sphère du domaine résérve, conçue toujours comme sphère des matières, varierait en fonction de la mesure dans laquelle le droit international lie les Etats en leur imposant des obligations. [...]." (ARANGIO-RUIZ, Gaetano. Le domaine réservé: l'organisation internationale et le rapport entre droit international et droit interne: cours général de droit international public. RCADI, 1990, t. 225. pp. 9-484. p. 31).

${ }^{214}$ CANÇADO TRINDADE, Antônio Augusto. Direito das organizações internacionais. 5. ed. rev., atual. e ampliada. Belo Horizonte: Del Rey, 2012. 838 p. p. 66.

${ }^{215}$ Id., ibid., pp. 131-2.
} 
inclinavam à ideia de que os assuntos que fossem de legítimo interesse internacional não estariam contidos na esfera do domínio reservado ${ }^{216}$. A partir daí, o conceito passou a ser relativizado, o que permitiu aos órgãos judiciais e políticos das organizações internacionais uma maior esfera de atuação ${ }^{217}$.

ARANGIO-RUIZ observa que o art. $2^{\circ}$, parágrafo $7^{\circ}$, da Carta da ONU representa a tradicional equação “domínio reservado/matérias não ligadas" ${ }^{218}$, e assevera que a prática das Nações Unidas parece, na maioria dos casos, desconsiderar o referido dispositivo. Busca motivos de natureza jurídica para essa desconsideração e acaba por defender a revisão do conceito à luz de um "limite relacional" do Direito Internacional com os direitos nacionais $^{219}$.

Esse fenômeno se deve, em grande parte, à globalização, que ampliou o leque de temas do Direito Internacional, fazendo com que cada vez mais, temas globais se tornassem locais, e temas locais ganhassem amplitude global ${ }^{220}$. Esse intercâmbio criou uma relação de transnormatividade entre o DIP e os direitos internos, proporcionando um ambiente no qual as normas são criadas para serem aplicadas independentemente de fronteiras geográficas, jurídicas, filosóficas e sociológicas ${ }^{221}$. JESSUP explica esse fenômeno como sendo a semente de um direito transnacional, que regula atos ou fatos que transcendem nações, e que compreende tanto o direito público quanto o privado ${ }^{222}$.

Desse panorama surge a principal questão contemporânea na relação entre o Direito Internacional e os direitos internos ${ }^{223}$. No campo teórico, as teorias monistas e dualistas clássicas, desenvolvidas no final do século XIX e começo do século XX, não oferecem

\footnotetext{
216 “Os órgãos políticos da ONU têm adotado várias medidas em suas tentativas de derrotar o argumento do domínio reservado. Geralmente, o primeiro passo tem sido a adoção de resoluções sobre o assunto. Na maioria dos casos é o que tem sido feito, embora em alguns poucos casos tenha-se enfrentado alguma dificuldade." (CANÇADO TRINDADE, Antônio Augusto. Op. cit., 2012, p. 94).

${ }^{217}$ CHARPENTIER, Jean. Le contrôle par les organisations internationales de l'exécution des obligations des états. RCADI, 1983-IV, t. 182. pp.143-245. pp. 162-4, passim.

${ }^{218}$ Domaine reserve/matières non liées.

${ }^{219}$ ARANGIO-RUIZ, Gaetano. Le domaine réservé: l'organisation internationale et le rapport entre droit international et droit interne: cours général de droit international public. RCADI, 1990, t. 225. pp. 448-79, passim.

${ }^{220}$ ARNAUD, André-Jean. O direito entre modernidade e globalização: lições de filosofia. Tradução de Patrice Charles Wuillaume. Rio de Janeiro: Renovar, 1999. p. 26.

221 “Assim, nesse contexto, as normas são criadas, pensadas e distribuídas fluindo e ultrapassando fronteiras não só geográficas, mas também jurídicas, filosóficas e sociológicas, criando e desenvolvendo um mesmo espaço global normativo, de produção e aplicação das normas jurídicas nas mais variadas identidades culturais." (MENEZES, Wagner. Ordem global e transnormatividade. Ijuí, RS: Unijuí, 2005, p. 205).

${ }^{222}$ JESSUP, Philip C. Direito transnacional. Trad. de Carlos Ramirez Pinheiro da Silva. São Paulo/Lisboa: Fundo de Cultura, 1956. p. 12.

${ }^{223}$ SHAW, Malcolm. International law. $6^{\text {th }}$ ed. Cambridge: Cambridge University Press, 2010. pp. 129-30.
} 
mais respostas adequadas ${ }^{224}$, tendo em vista o tempo presente. Mais precisamente, a dialética entre essas duas teorias, na prática, sempre se provou estéril. Ademais, na atualidade é quase impossível a generalização das relações jurídicas internacionais como sendo somente de subordinação ou de coordenação. Uma obrigação bilateral oriunda de um tratado internacional pode ser compreendida como de coordenação, contudo, uma resolução do Conselho de Segurança da ONU ou uma decisão de um tribunal internacional possuem uma natureza claramente subordinativa.

Importa esclarecer, no entanto, que a norma internacional sempre terá prevalência sobre a norma interna - a não ser que aquela mesma disponha o contrário. A prevalência do DIP é consolidada na prática internacional desde o parecer consultivo relativo aos interesses alemães na Alta Silésia, quando a CPJI relegou à lei interna o status de "mero fato" 225 . No campo do direito dos tratados - fonte "clássica" e expressão da vontade e soberania estatal -, a Convenção de Viena de 1969 deixou muito claro em seu art. 27 que nenhum Estado pode se recusar de cumprir um tratado, alegando questões de direito interno $^{226}$.

Logo, é o Direito Internacional que dita a tônica da relação com o direito interno, podendo fixar bases para coordenação ou estabelecer a subordinação, de acordo com a matéria ou ocasião ${ }^{227}$. CASELLA afirma, nesse sentido, que a "delimitação de competências e atribuições entre os direitos internos e o direito internacional estará sempre presente". Destaca, ainda, que o "direito internacional está inexoravelmente ligado, mas não pode ser subordinado aos ordenamentos jurídicos nacionais" 228 .

O estudo ora apresentado reflete a relação dos tribunais internacionais com os direitos internos. Ademais, a percepção das decisões judiciais internacionais como fonte do

${ }^{224}$ ACCIOLY, Hildebrando. Tratado de Direito Internacional Público. São Paulo: Waurtier Latin, 2009, v. III. p. 83 .

${ }^{225}$ CASELLA, Paulo Borba. Fundamentos do Direito Internacional pós-moderno. São Paulo: Quartier Latin, 2008. p. 1228.

226 "Logo, para o Direito Internacional, os atos normativos internos (lei, atos administrativos e mesmo decisões judiciais) são expressões da vontade de um Estado, que devem ser compatíveis com seus engajamentos internacionais anteriores, sob pena de ser o Estado responsabilizado internacionalmente. Consequentemente, um Estado não poderá justificar o descumprimento de uma obrigação internacional em virtude de mandamento interno, podendo ser coagido (com base na contemporânea teoria da responsabilidade internacional do Estado) a reparar os danos causados." (RAMOS, André de Carvalho. Pluralidade das ordens jurídicas: a relação do direito brasileiro com o direito internacional. Curitiba: Juruá, 2012. p. 28).

227 "The doctrine of the sovereignty of States [...] does not place any limit upon the subordination of States to the regulation of international law. In the Wimbledon and other cases the Court is quite explicit that there are no spheres of activity in which States sovereign powers are imprescriptible and incapable of being brought within the control of international law by treaty or by custom." (WALDOCK, Humphrey. General course on public international law. RCADI, 1962-II, t. 106. pp. 1-251. p. 173).

${ }^{228}$ CASELLA, Paulo Borba. Fundamentos do Direito Internacional pós-moderno. São Paulo: Quartier Latin, 2008. p. 1233. 
Direito Internacional Contemporâneo evidencia a importância não só institucional, mas também normativa desses órgãos na prática internacional, uma vez que sua atuação enseja não só a solução de uma controvérsia, mas também a construção do próprio DIP. Os Estados, outrossim, frente a essa nova realidade, devem envidar esforços para adequar seus ordenamentos internos, sob pena de usarem "uma velha ferramenta manual para consertar o chip de um computador de última geração",229.

${ }^{229}$ MENEZES, Wagner. Tribunais internacionais: jurisdição e competência. São Paulo: Saraiva, 2013. p. 288 . 


\section{DECISÕES JUDICIAIS INTERNACIONAIS: CONCEITOS, EFEI- TOS E EXECUÇÃO}

\subsection{INTRODUÇÃO E CONCEITO GERAL DE DECISÕES JUDICIAIS INTER- NACIONAIS}

Os tribunais internacionais pertencem à classe dos meios pacíficos jurídicos de solução de controvérsias internacionais. Para desenvolver a sua função pacificadora da vida social internacional, esses órgãos são dotados de um poder específico, que os difere dos demais meios de resolução de conflitos de sua classe: o poder jurisdicional, ou, simplesmente, a jurisdição. A jurisdição internacional, por sua vez, é um atributo por meio do qual os juízes internacionais resolvem de forma definitiva e obrigatória uma lide a eles submetida e, também, constroem o Direito Internacional para este e outros casos.

O exercício da jurisdição internacional depende, contudo, de atos próprios desse poder que, por intermédio de um processo decisório lógico e fundado em regras preestabelecidas, culmina em uma decisão que surte efeitos internos, ou seja, no âmbito da relação processual formal, e externos, interferindo na relação fática da qual a lide foi consequência e nela própria. Como consequência, faz-se necessária a observância e execução do decidido, quando assim for exigido.

Neste estudo se dará ênfase às decisões que produzem efeitos externos à relação processual formal, sendo essas: a sentença final, as medidas cautelares ou provisórias, os pareceres ou opiniões consultivas e outras como, os mandados de detenção e entrega do TPI e pedidos de cooperação previstos no Estatuto de Roma, e a decisão de pronta libertação de embarcações e tripulações do Tribunal Internacional para o Direito do Mar.

Essa separação se justifica na medida em que há decisões dos tribunais internacionais que geram efeitos somente no âmbito do processo, como, por exemplo, a maior parte das interlocutórias ou especificamente procedimentais, das quais podem ser citadas: ordens relativas à composição da corte e câmaras, de composição de comitês de especialistas, de juntada de casos por conexão, de limites temporais e materiais para cada ato específico, etc. ${ }^{230}$ Uma vez que essas não surtem efeitos externos relativos à controvérsia em si e suas partes, não serão abordadas neste estudo.

\footnotetext{
230 “[...] Orders and decisions usually deal with interlocutory or transient matters of procedure, but occasionally may be more substantive, such as orders regarding the composition of the court, orders for the constitution of a chamber, orders for the appointment and function of committees of experts, indications of provisional measures of protection, the joinder of cases, discountinuance, orders relating to aspects of intervention and of the revision of judgments (there has been no instance of this to date), and the tome limits
} 
O critério aqui adotado se assemelha ao exposto por CONDORELLI em relatório apresentado à Sociedade Francesa para o Direito Internacional, em 1987. Ao tratar da autoridade das decisões internacionais, o autor as delimitou em seu trabalho às que se referissem à resolução da controvérsia em si, função primordial das jurisdições internacionais. Afastou, assim, de sua análise, as essencialmente procedimentais, as transitórias $^{231}$ ou preparatórias, as que meramente declaram a competência do juízo, deixando o mérito para decisão posterior, e as que encerram a controvérsia sem resolução do mérito por incompetência do tribunal ${ }^{232}$.

Pode-se afirmar, portanto, que as decisões judiciais internacionais que serão analisadas neste capítulo possuem características semelhantes, isto é: referem-se à controvérsia em si e às partes, sendo, em geral, obrigatórias e vinculantes, e surtem efeitos externos que poderão refletir nos ordenamentos internos dos Estados. Desse modo, é importante a observação detida de cada uma delas, investigando seus conceitos, natureza jurídica e efeitos para, posteriormente, estudar os meios para sua observância e execução, o que se reportará, de imediato, aos Estados e seus poderes judiciários.

Para tal, em cada decisão analisada, inicialmente será feita uma análise histórica de suas origens, depois as discussões doutrinárias sobre sua natureza jurídica e, por fim, um estudo dos efeitos que delas advêm, sempre observando os entendimentos doutrinários e jurisprudenciais, desde sua origem histórica até o tempo presente. Assim, será possível desfrutar de uma melhor percepção da evolução da jurisdicionalização do Direito Internacional e seu respectivo alcance.

and quantity of written pleadings. Judgments, which may be interlocutory (for instance in dealing with preliminary objections or request for permission to intervene) or final, are conclusive for the matters with which they deal. They attract the obligation of compliance by the parties and interlocutory judgments are commonly regarded as 'binding' on the members of the court in subsequent phases of the case, even on those who dissented in the interlocutory phase." (ROSENNE, Shabtai. Practice and methods of International Law. London-Rome-New York: Oceana Publications, INC., 1984. p. 92).

231 Aqui, o autor considera, também, as medidas de caráter cautelar ou provisório, por serem transitórias. Nesse trabalho, foi decidido por incluí-las, pois, como será demonstrado adiante em momento oportuno, tais decisões são de fundamental importância na resolução da controvérsia e obrigam as partes tomarem medidas efetivas para afastar o periculum in mora.

232 “Cepandant, il y a décisions et décisions: celles-ci n'ont pas toutes la même importance, le même 'poids'. Par cess termes peu techniques nous entendons nous référer, non pas à l'un des nombreux critères formels de classement des décisions judiciaires internationales, mais plutôt au critère substantiel qui met l'accent sur le rapport plus ou moins immédiat entre chaque décision et la fonction essentiele de la jip de qui elle émane. Les jip sont - il ne faut pas l'oublier - des moyens parmi d'autres de règlement des différends. Il s'ensuit que, si l'on considère l'ensemble des décisions sous cet angle, on peut facilement accorder une signification éminente à celles qui réalisent directement et complètement la fonction essentielle de la 'machine à décision', par rapport à toutes les autres ayant un caractère lato sensu instrumental. [...].” (CONDORELLI, Luigi. L'autorite de la decision des Juridictions Internationales Permanentes. In: SOCIETÉ FRANÇAISE DE POUR LE DROIT INTERNATIONAL. Juridiction Internationale Permanente. Colloque de Lyon. Paris: Pedone, 1987. pp. 277-313. p. 278). 


\subsection{DECISÕES JUDICIAIS INTERNACIONAIS}

\subsubsection{Sentença internacional}

A sentença, na teoria geral do Direito, é o resultado do processo jurisdicional ${ }^{233}$, ou seja, é o instrumento pelo qual o juiz cumpre sua missão de pacificar a controvérsia a ele submetida. São várias as denominações que os diversos sistemas jurídicos empregam para designá-la. As mais comuns são: decisão e juízo. Há, ainda, quem use o termo "laudo arbitral" que, embora não seja completamente equivocado, pode incorrer em um erro conceitual, levando-se em conta a origem de uma e de outra expressão.

No Direito Internacional, os termos mais comuns são: judgment e decision (em inglês), e arrêt e décision (em francês) que, traduzidos para o português, significam sentença e decisão. No Estatuto da Corte Internacional de Justiça, por exemplo, ambos são usados como sinônimos. Assim, nos arts. 56, 57, 58, 60 e 61 do referido estatuto referemse à sentença, enquanto no art. 59 o termo escolhido foi decisão.

Já a Convenção Americana de Direitos Humanos ${ }^{234}$, a Convenção das Nações Unidas sobre o Direito do $\operatorname{Mar}^{235}$ e o Estatuto do Tribunal Penal Internacional ${ }^{236}$ usam exclusivamente o termo sentença. O Protocolo de Olivos ${ }^{237}$ preferiu o termo laudo para se referir à decisão final do processo no Tribunal Permanente de Revisão do Mercosul, o que se deve ao fato de que todo sistema de resolução de controvérsias do bloco regional se baseia na arbitragem, sendo esse último o órgão que reúne os requisitos para ser considerado um tribunal judicial internacional. Por fim, no Anexo II da Ata de Marraqueche $^{238}$, carta constitutiva da Organização Mundial do Comércio, o termo

\footnotetext{
233 “A sentença definitiva é o ato com o qual o juiz satisfaz a obrigação que lhe decorre da demanda judicial; por meio da sentença, concluiu ele sua missão (functus officio), salvo a necessidade de provisões consequentes [...].” (CHIOVENDA, Giuseppe. Instituições de Direito Processual Civil. Relação processual ordinária de cognição (continuação). 2. ed. Trad. de J. Guimarães Menegale. São Paulo: Saraiva, 1965, v. III. p. 197). “A sentença, já se disse, é o ato culminante do processo; é para ela que se dirigem teleologicamente todos os atos praticados no processo. Ela aglutina toda a atividade jurisdicional.” (ALVIM NETTO, José Manuel de Arruda. Direito Processual Civil: teoria geral do processo de conhecimento. São Paulo: Revista dos Tribunais, 1972. p. 66).

${ }^{234}$ CONVENÇÃO AMERICANA DE DIREITOS HUMANOS, arts. 54, 65, 66, 67, 68 e 69.

235 CONVENÇÃO DAS NAÇÕES UNIDAS SOBRE O DIREITO DO MAR. Anexo IV: Estatuto do Tribunal Internacional para o Direito do Mar, arts. 15, 30, 31, 32, 33 e 39.

${ }^{236}$ ESTATUTO DE ROMA DO TRIBUNAL PENAL INTERNACIONAL, arts. 24, 50, 66, 76, 81, 83-85.

${ }^{237}$ PROTOCOLO DE OLIVOS, arts. 23 e 25 a 30.

${ }^{238}$ ATA DE MARRAQUECHE, anexo II: Entendimento Relativo às Normas e Procedimento Sobre Solução de Controvérsias, arts. 2, 3, 17, 23 e 26.
} 
escolhido para designar o resultado das lides encaminhadas ao Órgão de Apelação foi relatório.

Independente de sua denominação, todas aquelas decisões que cumprirem com os requisitos a seguir especificados serão aqui designadas como sentença internacional. Para tanto, devem ser proferidas por um tribunal internacional, resolutivas da lide, obrigatórias e definitivas $^{239}$.

A qualificação internacional, obviamente, refere-se ao fato de serem proferidas por tribunais internacionais, ou seja, são emanadas em virtude da jurisdição conferida ao órgão por sujeitos de Direito Internacional e fruto de regras processuais pré-estabelecidas, conforme o conceito discutido no capítulo anterior. Por resolutivas da lide entende-se que cumpriram sua missão de pacificar o conflito, ou seja, o tribunal internacional deu uma resposta às partes, encerrando a causa do processo. Advém daí, também, sua obrigatoriedade, sendo as partes vinculadas ao dispositivo, devendo cumprir com o que foi decidido da maneira como as regras de cada órgão dispõem (império da jurisdição). Por fim, são definitivas, pois não há possibilidade de recurso.

As sentenças internacionais também são comumente classificadas em civis e penais. Civis são aquelas proferidas, em geral, por tribunais internacionais com competência para julgar Estados, ou seja, aqueles que podem figurar em seu polo passivo. Já as penais são comumente designadas para aquelas sentenças prolatadas por tribunais penais internacionais, como o Tribunal Penal Internacional para a Antiga Iugoslávia, o Tribunal Penal Internacional para Ruanda, o Tribunal Especial para Serra Leoa, o Tribunal Penal Internacional, etc. Essas sentenças se reportam a condutas criminais imputadas tão somente a indivíduos.

\subsubsection{Natureza jurídica}

A discussão sobre a natureza jurídica das sentenças internacionais não ocupa muitas páginas na doutrina jusinternacionalista publicista. Nas primeiras décadas do século XX, em razão da expansão da arbitragem internacional e da recém-criada Corte Permanente de Justiça Internacional, alguns autores, ao discorrer sobre a litigância internacional que se desenvolvia, destinaram principal atenção ao resultado final do processo arbitral e judicial.

\footnotetext{
${ }^{239}$ EL OUALI, Abdelhamid. Effets juridiques de la sentence internationale: contribution é l'etude de l'execution des normes internationales. Paris: LGDJ, 1984. p. 11.
} 
À época, a doutrina se dividia entre os que consideravam a natureza jurídica das sentenças internacionais ser de fato jurídico internacional - notadamente, o italiano MORELLI $^{240}$ - e aqueles que acreditavam se tratarem de atos jurídicos internacionais dentre os quais, o francês DELBEZ ${ }^{241}$.

Por fato jurídico internacional, entende-se, de maneira geral, todo fato ou acontecimento que o Direito Internacional considera reputar consequências jurídicas ${ }^{242}$. Incluem-se nessa categoria fatos naturais e aqueles causados pelo comportamento de um sujeito de direito. Ato jurídico internacional, por sua vez, é fruto da vontade do sujeito de DIP, a qual a ordem jurídica atribuirá efeitos constitutivos, modificativos ou extintivos de determinada situação jurídica, destacando-se na categoria, os tratados internacionais ${ }^{243}$.

MORELLI sustenta a teoria de que a sentença internacional é um fato jurídico internacional em sentido estrito ${ }^{244}$. Ademais, fundamenta sua posição no ponto em que não há um sujeito de direito a quem se possa imputar a sentença, pois os tribunais arbitrais e judiciais internacionais não são mais que meras instituições desprovidas de personalidade jurídica. A vontade - elemento que constitui o ato jurídico - é atributo inerente à subjetividade, a qual aqueles não possuem ${ }^{245}$. O autor afasta, igualmente, a possibilidade de a sentença internacional ser fruto da vontade dos Estados envolvidos na controvérsia, dos Estados-membros do tribunal e dos próprios juízes como indivíduos ${ }^{246}$.

Do outro lado, DELBEZ entende que as sentenças internacionais possuem a natureza jurídica de ato jurídico unilateral, cuja manifestação de vontade pode ser imputada ao árbitro ou ao tribunal arbitral. Mesmo não sendo sujeitos de Direito Internacional com capacidades plenas, esses possuem um poder derivado dos Estados, ou da OI que os constituiu e, para realizar seu fim de resolver a controvérsia, possuem a

\footnotetext{
${ }^{240}$ MORELLI, Gaetano. La sentenza internazionale. Padova: CEDAM - Casa Editrice Dott. Antonio Milani, 1931.

${ }^{241}$ DELBEZ, Louis. Les príncipes généraux du contentieux international. Paris: LGDJ, 1969. pp.126-47.

${ }^{242}$ MORELLI, Gaetano. Nozioni di Diritto Internazionale. 7. ed. riveduta. Padova: CEDAM - Casa Editrice Dott. Antonio Milani, 1967. p. 270.

${ }^{243}$ Id., ibid., pp. 279-81, passim.

${ }^{244}$ MORELLI, Gaetano. Op. cit., 1931, p. 80.

245 "Non esistendo alcun soggetto al quale la sentenza internazionale possa considerarsi imputata, essa, pur presentando notevoli analogie con la categoria degli atti giuridici, non rientra in questa categoria, constituendo invece un fatto giuridico in senso stretto. Conseguentemente il giudice internazionale ha la natura, non già di organo colletivo, bensí di instituto colettivo o internazionale; precisamente esso fa parte di quella speciale categoria di instituti colletivi la cui caratteristica consiste in ciò che l'attività esplicata nell'interesse di due o più soggetti è contemplata da una norma internazionale compe produttiva di conseguenze giuridiche." (MORELLI, Gaetano. Op.cit., 1967, p. 380).

${ }^{246}$ Id., ibid.
} 
capacidade - ainda que limitada - de emitir atos volitivos unilaterais que surtem efeitos jurídicos $^{247}$.

Expostas as duas posições, importa questionar se esses esforços de classificação que reportam às décadas de 20 e 30 e, principalmente, usam a arbitragem como ponto de partida da análise - encontram consonância no jurisdicionado Direito Internacional Contemporâneo. A resposta deve se basear no fato de que os tribunais internacionais são verdadeiros órgãos de solução jurídica de controvérsias, regidos pelo Direito Internacional Público, alguns, inclusive, com personalidade jurídica própria.

As sentenças que esses tribunais proferem possuem a natureza jurídica de norma internacional concreta individual ${ }^{248}$, podendo até extrapolar o limite inter partes se o assunto for de sensibilidade tal que a comunidade internacional como um todo possua interesse jurídico. É fruto do exercício jurisdicional internacional, no qual o juiz analisa o caso concreto à luz das normas gerais e, utilizando-se de recursos hermenêuticos e interpretativos, profere, ao final, uma decisão judicial definitiva e obrigatória que pacifique a controvérsia.

\subsubsection{Efeitos}

Os efeitos das sentenças internacionais podem ser divididos em dois grupos: os que dizem respeito à aparição da sentença no âmbito internacional, e os que se referem a sua aplicação nos ordenamentos jurídicos internos ${ }^{249}$. No primeiro grupo destacam-se o efeito obrigatório - do qual decorre a autoridade da coisa julgada -, o efeito definitivo e o efeito interpartes ou erga omnes. Já no segundo grupo figura com centralidade a aplicabilidade direta e suas implicações que remetem à questão da execução.

Considerado pela doutrina como o mais relevante, o efeito obrigatório é o que diferencia os meios jurídicos de solução de controvérsias dos demais meios pacíficos ${ }^{250}$. Isso se deve ao fato que, assim que proferida, a sentença se impõe como norma às partes e

\footnotetext{
${ }^{247}$ DELBEZ, Louis. Les príncipes généraux du contentieux international. Paris: LGDJ, 1969. pp. 127-8.

${ }^{248}$ EL OUALI, Abdelhamid. Effets Juridiques de la Sentence Internationale: contribution é l'etude de l'execution des normes internationales. Paris: LGDJ, 1984. p. 205.

${ }^{249}$ Id., ibid., p. 5.

250 "Les décisions des jip dont nous nous occupons, tout comme les sentences abitrales, se caractérisent de façon notoire par leurs effets obligatoires qui les distinguent nettement des 'documents' non astreignants par lesquels se concluent d'autres procédures de réglement des différends [...]." (CONDORELLI, Luigi. L'autorite de la decision des Juridictions Internationales Permanentes. In : SOCIETÉ FRANÇAISE DE POUR LE DROIT INTERNATIONAL. Juridiction Internationale Permanente. Colloque de Lyon. Paris: Pedone, 1987. p. 289).
} 
se reveste da força e garantia da coisa julgada, a qual deriva da face do império da jurisdição internacional $^{251}$. Assim, pode-se concluir que o efeito obrigatório das sentenças internacionais - e de todas as decisões judiciais internacionais - deriva fundamentalmente do poder jurisdicional internacional concedido aos tribunais internacionais pelos sujeitos de direito internacional ${ }^{252}$.

Outra fonte da qual se pode extrair o efeito obrigatório da sentença internacional está no Pacta Sunt Servanda e no cumprimento de boa fé do tratado que criou o tribunal internacional e dos documentos que lhe atribuíram jurisdição ${ }^{253}$. Ora, todo ato constitutivo de um órgão jurisdicional internacional traz em si a obrigação de obedecer às suas decisões proferidas. Logo, não seria lógico, tendo em vista os fins a que se destina, a recusa da vinculação ao determinado ato, especialmente no tocante às sentenças.

A principal consequência formal do efeito obrigatório das sentenças internacionais é a constituição da coisa julgada. Considerado uma garantia fundamental nos ordenamentos jurídicos internos contemporâneos, o instituto também se aplica ao Direito Internacional, antigamente como uma analogia com o direito privado e, mais recentemente, como um verdadeiro atributo das sentenças internacionais. LIMBURG, em curso ministrado na Academia de Haia, em 1929, enumerou como efeitos da coisa julgada: a

251 "Cet imperium a des conséquences complexes: il rend obligatoire le dispositif de la sentence, généralement pour le seul cas d'espèce [...].” (ASCENCIO, Hervé. La notion de Jurisdiction Internationale en Question. In: SOCIETÉ FRANÇAISE POUR LE DROIT INTERNATIONAL. La jurisdictionalisation du Droi International. Collowur de Lille. Paris: Pedone, 2003. p. 178).

252 “Ademais, quando um Estado de submete à jurisdição de uma determinada Corte, ele não está só aceitando suas sentenças, mas se comprometendo previamente com os dispositivos de seu funcionamento. Compromete-se, também, em dar validade e eficácia aos seus procedimentos, assumindo, por conseguinte, compromisso que abrange a todos os seus jurisdicionados à medida que sejam responsáveis igualmente por seus compromissos. Se essa não for a ideia, melhor que o Estado não se sujeite à jurisdição de um Tribunal Internacional". (MENEZES, Wagner. Tribunais Internacionais: jurisdição e competência. São Paulo: Saraiva, 2013. p. 288). No mesmo sentido, Condorelli: "Il convient de rappeler quelle est la source fondamentale de la force contraignante des décisions qui nos intéressent : celle-ci repose, tout comme le pouvoir de décider du 'juge', sur la volonté des Etats en différend, sur leur engagement préalable, contracté par le biais d'instruments de types variés, de se conformer à la décision finale ou, plus précisément, à son dispositif. Si le juge a été autorisé à décider ex aequo et bono, un tel engagement constitue la source exclusive de l'effet obligatoire inter partes de la décision finale. Pour ce qui est de la décision secundum jus, la force celle-ci se base toujours sur le fait que les parties ont assumé d'avance l'obligation de la respecter, mais en fait la norme dont le juge a fait application était déjà obligatoire pous les Etats concernés. Ici, donc, la force contraignante de la décision ne prend pas appui exclusivement sur l'accord par lequel on a chargé le juge de juger, mais aussi - ou en même temp - sur l'effet propre aux normes appliquées par lui. A la situation préexistante en droit, la décision se borne dans ces cas à ajouter l'effet de la certitude juridique, certitude que les Etats concernés se sont accordés préablement à considérer comme incontestable." (CONDORELLI, Luigi. L'autorite de la decision des Juridictions Internationales Permanentes. In: SOCIETÉ FRANÇAISE DE POUR LE DROIT INTERNATIONAL. Juridiction Internationale Permanente. Colloque de Lyon. Paris: Pedone, 1987. pp. 290-1).

${ }^{253}$ EL OUALI, Abdelhamid. Effets Juridiques de la Sentence Internationale: contribution é l'étude de l'execution des normes internationales. Paris: LGDJ, 1984. p. 65. 
prevenção de uma nova adjudicação sobre o mesmo caso, a força probante do julgado e a atribuição de sua executoriedade ${ }^{254}$.

Outro efeito das sentenças internacionais é que essas são definitivas, ou seja, uma vez proferidas são finais, não cabendo recurso. Isso se deve, primeiramente, a uma questão estrutural: a inexistência de hierarquia entre os vários tribunais internacionais, não sendo um superior ao outro e, logo, não podendo um "reformar" decisão de seu par. Em um segundo momento, a questão histórica: a herança da arbitragem, lembrando que o art. 81 da primeira Convenção de Haia, de 1907, já cristalizava esse entendimento ${ }^{255}$.

O efeito definitivo se justifica no fato de que o acesso a um tribunal internacional é geralmente tido como um "meio supremo" de resolução de um determinado conflito, em razão de seu poder jurisdicional. Assim, qualquer questionamento referente à sentença contraria sua própria natureza de norma concreta individual, o que relaciona o efeito aqui descrito de forma imediata ao efeito obrigatório e contribui para a distinção do meio judiciário de solução de controvérsias internacionais dos demais ${ }^{256}$.

Na prática internacional, entretanto, surgiram argumentos criativos para a mitigação do efeito definitivo. Questionar a validade da sentença internacional vem sendo, por exemplo, o principal argumento dos sucumbentes no processo internacional para tentar escapar de seus efeitos. São variados os requisitos que devem constar no processo decisório internacional para que seu produto seja válido, contudo, na maioria das vezes, alega-se que o tribunal excedeu seus poderes atribuídos pelos Estados, ou que houve corrupção de um dos seus membros, ou, ainda, uma séria violação das regras processuais, como a ausência de fundamentação da sentença ${ }^{257}$.

A regra geral da jurisdição internacional é que as sentenças produzem efeitos somente entre as partes. É o que está estabelecido na absoluta maioria dos estatutos e tratados constitutivos, no entanto, uma análise mais detida da própria estrutura, função e matéria de uma sentença internacional pode relativizar esse entendimento. Considerando a estrutura dos julgados, percebe-se que esses são divididos, a grosso modo, em relatório, fundamentação e dispositivo. Desses, apenas o último realiza estritamente a coisa julgada entre as partes. Já a fundamentação tem papel importante na função de jurisdictio dos

\footnotetext{
${ }^{254}$ LIMBURG, J. L'autorité de chose jugée des décisions des jurisdictions internationales. RCADI, 1929-V, t. 30. pp. 519-618. pp. 527-8.

${ }^{255}$ EL OUALI, Abdelhamid. Effets Juridiques de la sentence internationale: contribution é l'étude de l'execution des normes internationales. Paris: LGDJ, 1984. pp. 109-10.

${ }^{256}$ Id., ibid., p. 111.

${ }^{257}$ SCHACHTER, Oscar. The enforcement of International Judicial and Arbitral Decisions. The American Journal of International Law, 1960, v. 54. pp. 1-24. p. 3. A discussão será aprofundada no tópico 3, infra.
} 
tribunais internacionais, ou seja, na construção progressiva, caso a caso, do Direito Internacional $^{258}$. Forma-se aqui o que alguns doutrinadores entendem por "coisa julgada interpretativa" ${ }^{, 259}$.

Do mesmo modo, dependendo da matéria em que se insere o conflito, sua própria natureza estenderá os efeitos da sentença para a sociedade internacional como um todo, atribuindo-lhe, portanto, o efeito erga omnes. É o caso, por exemplo, da sentença que declara uma determinada obrigação como pertencente ao rol do jus cogens, ou a que reconhece a existência de um costume geral, ou ainda a que trata de espaços comuns, direitos humanos, meio ambiente e qualquer outro tema em que todos os sujeitos de direito internacional possuam interesse jurídico ${ }^{260}$. Dessa forma, todos ficarão vinculados ao que foi decidido pelo tribunal, mesmo não sendo partes no conflito.

Finalmente, resta conhecer os contornos do efeito da aplicabilidade imediata, tema que será discutido com mais ênfase quando for tratada a questão da observação e execução das decisões judiciais internacionais. A sentença proferida por um tribunal internacional, além de obrigatória e definitiva, deve ser cumprida de forma imediata pelos Estados de alguma forma envolvidos, seja por ser a parte sucumbente, ou em função de o objeto da lide se encontrar sob sua jurisdição.

Assim sendo, uma vez prolatada, a sentença internacional deve ser integralmente cumprida, não cabendo qualquer tipo de consideração por parte dos direitos internos. Ela não pode ser essa submetida ao juízo de delibação pelos tribunais internos, pois não se trata de uma sentença estrangeira e sim internacional. Opera aqui, uma relação vertical entre o

\footnotetext{
258 “[...] Il faut toutefois reconaître que l'exposé des motifs (c'est-a-dire le raisonnement du juge, les affirmations qu'il prononce, l'analyse qu'il fait de l'etat du droit international en la matière ou dans des domaines proches, etc.), mais parfois aussi le dispositif, ont à déployer une autorité bien plus large, quoinque certes moins précise et moins définie. C'est à cette sorte d'autorité que se réfère l'article $38, \$ 1$, litt. $d$, du Statut de la CIJ, lorsqu'il attribue aux 'décisions judiciaires' le rôle de 'moyen auxiliaire de détermination des règles de droit." (CONDORELLI, Luigi. L'autorite de la decision des Juridictions Internationales Permanentes. In: SOCIETÉ FRANÇAISE DE POUR LE DROIT INTERNATIONAL. Juridiction Internationale Permanente. Colloque de Lyon. Paris: Pedone, 1987. p. 306).

${ }^{259}$ RAMOS, André de Carvalho. Processo Internacional de Direitos Humanos. Análise dos sistemas de apuração de violações de direitos humanos e a implementação das decisões no Brasil. São Paulo: Saraiva, 2012. p. 236.

${ }^{260}$ Insere-se aqui a discussão da possibilidade de uma actio popularis no Direito Internacional, que ainda resta incontroversa, mas já encontra bases doutrinárias e jurisprudenciais para seu desenvolvimento. Vide: VILLALPANDO, Santiago. L'érmergence de la communauté internationale dans la responsabilité des Etats. Paris: PUF, 2005; MABYE, Kéba. L'intérêt pour agir devant la Cour internationale de Justice. RCADI, 1988-II, t. 209. pp. 316-8; CANÇADO TRINDADE, Antônio Augusto. International Law for Humankind: Towards a New Jus Gentium (I). General course on Public International Law. RCADI, 2005, v. 316. pp. 356-9.
} 
tribunal internacional e seus jurisdicionados, gerando um imperativo de cooperação jurídica, fundado no poder jurisdicional internacional daqueles ${ }^{261}$.

\subsubsection{Medidas cautelares ou provisórias}

Nos ordenamentos jurídicos internos, a figura da medida cautelar de caráter provisório é bem destacada, possuindo a função de resguardar determinado interesse jurídico quando esse se encontra em risco. Trata-se, portanto, de uma medida de urgência concedida pelo juiz ao constatar a presença de requisitos do fumus boni iures e do periculum in mora.

No Direito Internacional, o surgimento das medidas cautelares se deu com a constituição do primeiro tribunal judicial internacional: a Corte Centroamericana de Justiça. NAPOLITANO aponta que o art. 18 da Convenção de Washington, de 1907, foi o primeiro dispositivo a tratar desse procedimento ao estabelecer que, desde o momento que uma reclamação é instalada até a sentença final, qualquer uma das partes pode solicitar ao tribunal que ordene a conservação de determinada situação para não agravar a controvérsia ${ }^{262}$.

No primeiro projeto de artigos do Estatuto da CPJI não havia, sequer, a previsão dessas decisões. Foi o jurista brasileiro Raul Fernandes que sugeriu a inclusão de um artigo que possibilitasse às partes requererem uma ordem provisória da Corte quando diante de uma situação que pusesse em risco o devido desenvolvimento do processo jurisdicional ${ }^{263}$. Essa proposição foi baseada em projeto semelhante estabelecido em um dos chamados tratados Bryan ${ }^{264}$, o de 13 de outubro de 1914, entre o Reino da Suécia e os Estados Unidos da América e, depois de várias alterações, tornou-se o ainda hoje conhecido art. 41

\footnotetext{
261 "Exatamente por esta razão, e considerando a necessidade de efetivação das normas e princípios de Direito Internacional, que motivaram a criação das cortes internacionais, estabeleceu-se, para com este, o 'modelo vertical', também chamado 'supraestatal', que, de um lado, reconhece a igualdade formal entre todos os Estados no plano internacional, mas, ao mesmo tempo compreende que um órgão judicial internacional, quando criado, é investido não somente dos poderes necessários a julgar os casos e indivíduos inseridos em suas competências pelos respectivos tratados constitutivos, mas também da autoridade para exigir dos Estados (ao menos signatários), o cumprimento de suas ordens, com caráter vinculante." (VERGUEIRO, Luiz Fabrício Thaumaturgo. Implementação da Cooperação Jurídica Internacional Vertical. Tese de doutorado. Universidade de São Paulo. São Paulo, 2012. p. 75).

${ }^{262}$ NAPOLITANO, Silvina S. Gonzáleas. Las medidas provisionales en Derecho Internacional ante las Cortes y Tribunales Internacionales. Buenos Aires: La Ley, 2004. p. 6.

${ }^{263}$ COUR PERMANENTE DE JUSTICE INTERNATIONALE. Procès-Verbaux des Séances du Comité. 16 juin-24 juillet 1920. Avec Annexes. La Haye: Van Langenhuysen Frères, 1920. p. 609.

${ }^{264}$ Tratados de paz firmados entre Estados Unidos, China, França e Suécia nos anos de 1913 e 1914 que obrigavam as partes a submeter todas as controvérsias não resolvidas pelos meios diplomáticos a uma comissão de inquérito, sendo que durante esses procedimentos a guerra não seria permitida. No texto foi prevista a possibilidade de indicar medidas provisórias, contudo, sem caráter obrigatório.
} 
do Estatuto da Corte Permanente e de sua sucessora. A partir de então ${ }^{265}$, essas decisões começaram a ter seu contorno desenhado pela prática dos tribunais internacionais.

Também conhecidas como medidas provisionais, interinas, protetivas, remédios provisórios, etc., podem ser assim consideradas todas aquelas decisões que se enquadram no conceito proposto por NAPOLITANO:

\begin{abstract}
Las medidas provisionales en la jurisdicción internacional son aquellas acciones o abstenciones dispuestas por los jueces y árbitros internacionales prima facie competentes en un asunto, en caso de urgencia, con el fin de preservar los derechos de las partes contendientes o los bienes en litigio, así como la eficacia del proprio proceso, incluyendo la protección de los medios de prueba y las personas a él vinculadas, o de impedir que se agrave o extienda la controversia, estando pendiente la sentencia final. ${ }^{266}$
\end{abstract}

Destrinchando o conceito adotado, as medidas cautelares de caráter provisório internacional podem ser: i) positivas ou negativas, quanto ao ato; ii) proferidas por juiz ou árbitro internacional competente, prima facie, para adjudicar o caso principal; iii) de caráter de urgência e de preservação de direitos, bens, provas, pessoas e a própria eficácia do processo; e iv) de caráter provisório e preventivo de uma escalada da controvérsia, enquanto não for prolatada a sentença final.

São pressupostos para sua concessão, de maneira geral, a jurisdição do tribunal ao qual o pedido é endereçado, a existência de um direito ou interesse a ser protegido em conexão com uma causa principal existente ou futura, e o risco de um prejuízo irreparável: o periculum in mora.

Quanto às fontes das medidas cautelares no Direito Internacional, existe uma discussão doutrinária. Uma corrente minoritária entende que essas decisões só podem ser efetivadas se constantes nos tratados constitutivos dos tribunais internacionais. Já grande parte da doutrina especializada e da jurisprudência entende que tais medidas são inerentes ao exercício jurisdicional, podendo cada tribunal estabelecer se é competente para conceder ou não a ordem ${ }^{267}$.

\footnotetext{
${ }^{265}$ A primeira medida provisória indicada pela CPJI foi em 8 de janeiro de 1927, no Caso da Denúncia do Tratado de 2 de novembro de 1865, entre China e Bélgica (GUGGENHEIM, Paul. Les mesures conservatoires dans la procédure arbitrale et judiciaire. RCADI, 1932-II, t. 40. pp. 645-764. p. 706).

${ }^{266}$ NAPOLITANO, Silvina S. Gonzáleas. Las medidas provisionales en Derecho Internacional ante las Cortes y Tribunales Internacionales. Buenos Aires: La Ley, 2004. p. 9.

267 "It is possible, but not certain, that the universality of the principle leads to the conclusion that an international tribunal has an inherent power to grant interim measures even if the instrument under which is established does not expressly give it that power." (COLLINS, Lawrence. Provisional and protective measures in international litigation. RCADI, 1992-III, t. 234. pp. 9-238. p. 215).
} 
Para PESCATORE, a existência de medidas provisórias no silêncio dos tratados que instituem os tribunais se deve ao fato de que essas são parte do desenvolvimento natural do procedimento judiciário. De acordo com o autor, as decisões aqui discutidas têm a função de "manter abertas as possibilidades de solução" e de sustentar "a igualdade de chances entre as partes", permitindo à decisão final sua plena eficácia. O autor conclui afirmando que: "a instituição de medidas provisórias ou conservativas é inerente aos poderes exercidos pelo juiz na direção do processo",268.

Exemplo disso é o caso da Corte Europeia de Direitos Humanos que, mesmo não tendo previstas as medidas cautelares na Convenção Europeia de Direitos Humanos, essas constam explicitamente no Regulamento da Corte desde o Protocolo $n^{\circ} 11$, e vêm sendo usadas com frequência desde então. Há, entretanto, impasses na doutrina sobre a força vinculante dessas decisões, uma vez que não foram instituídas pelo tratado constitutivo, mas pelo regulamento ${ }^{269}$.

As medidas cautelares são previstas em quase todos ${ }^{270}$ os tratados constitutivos e regulamentos internos dos tribunais aos quais o Brasil se submeteu à jurisdição. No âmbito universal, no Estatuto da Corte Internacional de Justiça, elas se encontram no art. 41 e, no Regulamento da CIJ, nos arts. 73 a 78. Na Convenção das Nações Unidas sobre o Direito do Mar, que criou o Tribunal Internacional para o Direito do Mar, encontram-se no art. 290 e, no Estatuto do Tribunal, no art. 25. No âmbito regional, a Convenção Americana de Direitos Humanos prevê a aplicação dessas medidas em seu art. 63, inciso 2, e no Regulamento da Corte no art. 25. O Protocolo de Olivos traz a questão nos seus arts. 15 e 24, regulado na Resolução CMC n ${ }^{23 / 04 .}$

\subsubsection{Natureza jurídica}

A discussão sobre a natureza jurídica das medidas cautelares internacionais passa, necessariamente, por sua fonte. Vasta parcela da doutrina entende que essas decisões surgiram na ordem internacional pela porta dos princípios gerais do direito. Esses, por sua vez, são considerados fontes do Direito Internacional Público, conforme consta no rol do

\footnotetext{
${ }^{268}$ PESCATORE, Pierre. Les mesures conservatoires et les referes. In: SOCIETÉ FRANÇAISE DE POUR LE DROIT INTERNATIONAL. Juridiction Internationale Permanente. Colloque de Lyon. Paris: Pedone, 1987. pp. 315-62. p. 323.

${ }^{269}$ NAPOLITANO, Silvina S. Gonzáleas. Las medidas provisionales en Derecho Internacional ante las Cortes y Tribunales Internacionales. Buenos Aires: La Ley, 2004. p. 38.

${ }^{270}$ Excetuando-se o Sistema de Solução de Controvérsias da OMC.
} 
art. 38, no parágrafo $1^{\circ}$, alínea "c" do Estatuto da CIJ, e possuem a função primordial de garantir a completude do sistema jurídico internacional, preenchendo suas lacunas ${ }^{271}$. Assim, os princípios gerais do direito universalmente aceitos são "coletados" dos ordenamentos jurídicos internos e passam a compor o DIP na medida em que os tribunais internacionais assim os reconhecem.

PESCATORE coaduna com essa posição, para quem a natureza jurídica dessas decisões é de princípio geral de direito, sendo, portanto, inerente ao desenvolvimento normal de um processo judiciário. O autor afirma, ainda, que seu raciocínio se inspira na aplicação do princípio do effet utile no âmbito da função judiciária, que preenche as lacunas onde elas existem e inspira os juízes a uma melhor interpretação e aplicação do direito positivo ${ }^{272}$.

No Caso da Companhia Elétrica de Sofia e da Bulgária, a Corte Permanente de Justiça Internacional entendeu em sede de medida cautelar - ou provisória - que as disposições em seu Estatuto sobre essa forma de decisão "aplica o princípio universalmente aceito pelos tribunais internacionais" de que "as partes devem se abster de qualquer medida" que possa por em risco a execução da decisão final ou que gere uma extensão da controvérsia ${ }^{273}$.

NAPOLITANO, por outro lado, aborda a questão da natureza jurídica das medidas cautelares internacionais pelo ponto de vista processual, questionando se se trata de uma questão de procedimento, de jurisdição ou de sui generis. Segundo a autora, os que defendem ser de natureza procedimental baseiam-se no fato de que tais medidas são previstas na maioria dos regulamentos sob o título de "procedimentos". Já os que sustentam ser a natureza de jurisdição, o fazem com base no entendimento que aquelas miram uma conduta extraprocessual das partes, extrapolando os limites formais. Por fim, há os que advogam a tese de que as decisões aqui discutidas são sui generis, pois não é possível lhes aplicar uma classificação única ${ }^{274}$.

\footnotetext{
${ }^{271}$ COMBACAU, Jean ; SUR, Serge. Droit International Public. 2. ed. Paris: Montchrestien, 1995. p. 107.

${ }^{272}$ PESCATORE, Pierre. Les mesures conservatoires et les referes. In : SOCIETÉ FRANÇAISE DE POUR LE DROIT INTERNATIONAL. Juridiction Internationale Permanente. Colloque de Lyon. Paris: Pedone, 1987. p. 324.

273 "Considérant que la disposition précitée du Statut applique le principe universellement admis devant les juridictions internationales et consacré d'ailleurs dans maintes conventions auxquelles la Bulgarie a été partie, - d'après lequel les parties en cause doivent s'abstenir de toute mesure susceptible d'avoir une répercussion préjudiciable à l'exécution de la décision à intervenir et, en général, ne laisser procéder à aucun acte, de quelque nature qu'il soit, susceptible d'aggraver ou d'étendre le différend;[...]." (COUR PERMANENTE DE JUSTICE INTERNATIONALE. Compagnie d'eletricité de Sofia et de Bulgarie (mesures conservatoires). Ordonnance du 05 décembre 1939. Série A/B n 79. p. 199).

${ }^{274}$ NAPOLITANO, Silvina S. Gonzáleas. Las medidas provisionales en Derecho Internacional ante las Cortes y Tribunales Internacionales. Buenos Aires: La Ley, 2004. p. 13.
} 
Pode-se concluir, enfim, que as medidas cautelares no Direito Internacional foram coletadas dos direitos internos pelos próprios tribunais por meio da utilização dos princípios gerais de Direito. A partir do momento em que essas começaram a ser positivadas nos tratados constitutivos e regulamentos e a prática dos tribunais internacionais passou a adotá-las como uma importante ferramenta da sua atividade jurisdicional, sendo tidas como decisões interlocutórias, tornaram-se elementos imprescindíveis do processo judicial internacional. Assim, guardam a natureza de decisão jurisdicional internacional ${ }^{275}$, sendo obrigatórias às partes.

\subsubsection{Efeitos}

O efeito obrigatório das medidas cautelares internacionais foi um dos temas mais discutidos pela doutrina jusinternacionalista quando em pauta as questões ligadas a tribunais internacionais e à litigância internacional. Já no momento em que o Comitê de Juristas se reuniu para pensar o Estatuto da Corte Permanente de Justiça Internacional, o debate em torno dessa questão se iniciou, primeiro tendo por base a origem - disposição semelhante nos tratados Bryan - da proposição de Raul Fernandes e, depois, os termos empregados na versão definitiva ${ }^{276}$. Essas questões acompanharam a evolução história do instituto, como será melhor analisado a seguir.

A principal fonte do efeito obrigatório - assim como em todas as decisões aqui discutidas - é o poder jurisdicional conferido aos tribunais internacionais pelos sujeitos de Direito Internacional. Partindo dessa premissa, a prática internacional enfrentou ao longo dos anos, o problema da competência para indicar medidas cautelares, tendo em vista o pressuposto da jurisdição para o mérito da controvérsia ${ }^{277}$.

\footnotetext{
275 "Contrariamente, se piensa que la indicación de medidas provisionales por la CIJ ya sea que adopte la forma de una providencia o cualquier otra, tiene la misma fuerza que una decisión de la Corte, la cual no obliga sino a las partes y respecto del caso particular, conforme al articulo 59 del ECIJ. Incluso la ubicación de las medidas provisionales tanto en el Estatuto como en el Reglamento implica que se las considera decisiones judiciales que regulan obligatoriamente el procedimento." (NAPOLITANO, Silvina S. Gonzáleas. Las medidas provisionales en Derecho Internacional ante las Cortes y Tribunales Internacionales. Buenos Aires: La Ley, 2004. p. 167).

${ }^{276}$ GUGGENHEIM, Paul. Les mesures conservatoires dans la procédure arbitrale et judiciaire. RCADI, 1932-II, t. 40. pp. 645-764. p. 678.

277 "Il primo problema sul quale le citate ordinanze rivelano l'orientamento della Corte risguarda il rapporto tra competenza ad indicare misure cautelari e competenza sul merito della controversia in relazione alla quale le misure stesse sono richeste (c.d. competenza principale).” (VILLANI, Ugo. In tema di indicazione di misure cautelari da parte della Corte Internazionale di Giustizia. Rivista di Diritto Internazionale, 1974, v. LVII. pp. 657-681. p. 658).
} 
De acordo com OELLERS-FRAHM, há cinco testes que podem ser aplicados na avaliação de um determinado tribunal internacional a fim de saber se o mesmo é competente ou não para ordenar medidas cautelares em relação à jurisdição para adjudicar o mérito. O primeiro exigiria a constatação inequívoca da existência dessa jurisdição a fim de indicar as referidas medidas, o que negligenciaria seu caráter provisório e não é o que se observa na prática; o segundo não levaria em consideração qualquer vínculo de jurisdição, o que feriria o seu próprio caráter voluntário no plano internacional; o terceiro, também conhecido como "teste da possibilidade", refere que deve haver algum instrumento emanado pelas partes na controvérsia que indique prima facie, a jurisdição do tribunal para decidir o mérito; o quarto seria o "teste da probabilidade" que, apesar de nunca ter sido adotado, foi defendido por vários juízes em opiniões apartadas, postulando que as medidas protetivas devem ser concedidas se constatado que o tribunal possui probabilidade de, também, ser competente para o mérito; o quinto teste, por fim, foi proposto por Jimenez de Aréchaga, segundo o qual o poder de indicar essas medidas advém do Estatuto dos Tribunais e não dos instrumentos de submissão das partes a eles ${ }^{278}$.

A prática da Corte Internacional de Justiça é esclarecedora dos principais pontos dessa problemática. Já na primeira decisão relativa a medidas cautelares, a CIJ, em 1951, no Caso da Companhia Angloiraniana de Petróleo, manifestou-se no sentido de que a controvérsia ali discutida não "ficava completamente de fora da jurisdição internacional" ${ }^{, 279}$. De forma semelhante, decidiu a Corte no Caso Interhandel, em $1957^{280}$. Já em 1972, no Caso Jurisdição das Pescarias, de forma explícita, foi declarado que, para analisar e conceder a ordem que institui as medidas protetivas, não é necessário demonstrar de forma absoluta que a Corte tem jurisdição no mérito ${ }^{281}$.

278 OELLERS-FRAHM, Karin. Interim measures of protection. In: BERNHARDT, Rudolf (Ed.). Encyclopedia of Public International Law. Settlement of Disputes. Amsterdam - New York - Oxford: North Holland Publishing Company, 1981, v. 1. pp. 69-72. p. 70.

279 "....] whereas it cannot be accepted a priori that a claim based on such a complaint falls completely outside the scope of international jurisdiction [...]." (INTERNATIONAL COURT OF JUSTICE. AngloIranian Oil Co. Case. Request for the indication of Interim Measures of Protection (United Kigdom v. Iran). Order of July $15^{\text {th }} 1951$. p. 93).

280 "Whereas, finally, the decision given under this procedure in no way prejudges the question of the jurisdiction of the Court to deal with the merits of the case and leaves unaffected the right of the Respondent to submit arguments against such jurisdiction [...]." (INTERNATIONAL COURT OF JUSTICE. Interhandel Case (Switzerland v. United States of America). Request for the indication of Interim Measures of Protection. Order of October 24 ${ }^{\text {th }}$ 1957. p. 111). Ainda, sobre essa mesma decisão vide o comentário de BARILE, Giuseppe. Sulla competenza della Corte Internazionale di Giustizia ad indicare misure cautelari. Rivista di Diritto Internazionale, 1958, v. XLI. pp. 111-22.

281 "Whereas on a request for provisional measures the Court need not, before indicating them, finally satisfy itself that it has jurisdiction on the merits of the case [...]." (INTERNATIONAL COURT OF JUSTICE. Fisheries Jurisdiction Case (Federal Republic of Germany v. Iceland). Request for the indication of Interim Measures of Protection. Order of August 17 ${ }^{\text {th }}$ 1972. p. 33). 
Foi, entretanto, a decisão de indicação de medidas cautelares nos Casos dos Testes Nucleares que levou a Corte a definir uma regra para esclarecer o problema: a demonstração de jurisdição prima facie para o mérito da controvérsia ${ }^{282}$. Para VILLANI, a partir desse momento, a CIJ adotou um critério positivo, que é a existência de um título de jurisdição - mesmo que posteriormente declarado não válido - que demonstre, naquele instante, que há pelo menos um indício de que o tribunal poderá decidir o mérito do litígio $^{283}$. Logo, desde que demonstrado que há um título de jurisdição prima facie, não há que se questionar a obrigatoriedade das medidas cautelares, alegando razões de jurisdição.

Outra discussão se refere ao ato que indica as medidas cautelares internacionais. Alguns autores alegam que se trata de uma "ordem" que não possui os mesmos efeitos de uma decisão. Em voto apartado na decisão sobre a concessão de outras medidas cautelares relativas ao "Caso sobre a Aplicação da Convenção sobre Prevenção e Punição do Genocídio" (Bósnia e Herzegovina v. Iugoslávia), o juiz SHAHABUDDEEN faz uma distinção de "indicação de medidas" e "medidas indicadas". Na primeira, a questão é o efeito da decisão e, na segunda, se essas representam um judicial finding daquilo que deve ser feito para preservar os direitos em disputa. O juiz conclui afirmando que, mesmo sob a argumentação de que a indicação não tem efeito obrigatório, as medidas em si representam uma importante conclusão judicial, e a recusa de sua implementação significa uma inconsistência ${ }^{284}$.

\footnotetext{
282 "Whereas on a request for provisional measures the Court need not, before indicating them, finally satisfy itself that it has jurisdiction on the merits of the case, and yet ought not to indicate such measures unless the provisions invoked by the Applicant appear, prima facie, to afford a basis on which the jurisdiction of the Court might be founded; [...]." (INTERNATIONAL COURT OF JUSTICE. Nuclear Tests Case (New Zeland v. France). Request for the indication of Interim Measures of Protection. Order of June 22 ${ }^{\text {nd }}$ 1973. p. 137; INTERNATIONAL COURT OF JUSTICE. Nuclear Tests Case (Australia v. France). Request for the indication of Interim Measures of Protection. Order of June 22 $2^{\text {nd }}$ 1973. p. 101). Para uma visão crítica do caso vide: DANIELE, Luigi. L'ordonnance sur la demande d'examen de la situation dans l'Affaires des Essais Nucléaires et le pouvoir de la Cour Internationale de Justice de régler sa prope procédure. Revue Générale de Droit International Public, 1996, t. C. pp. 653-71.

${ }^{283}$ VILLANI, Ugo. In tema di indicazione di misure cautelari da parte della Corte Internazionale di Giustizia. Rivista di Diretto Internazionale. 1974, v. LVII. pp. 657-61.

284 "[...] A distinction may be drawn between the indication of measures and the measures indicated. The question relating to the 'indication' is whether it has the effect of a judicial decision which attaches a legal obligation to a party. The question relating to the 'measures' is whether they represent a judicial finding as to what needs to be done to preserve the rights in contest. In my opinion, even if the indication is not legally binding, the measures possess the character of a judicial finding as to what was required to preserve those rights pende lite, that finding having been made after due hearing by the Court sitting as a court of law in exercise of a specific power conferred by law. It follows that any non-implementation, even if not in breach of a legal obligation, represents an inconsistency with that judicial finding." (INTERNATIONAL COURT OF JUSTICE. Case concerning application of the Convention on the Prevention and Punishment of the Crime of Genocide (Bosnia and Herzegovina v. Yugoslavia). Further Requests for the Indication of Provisional Measures. Order of 13 September 1993. Separate Opinion of Judge Shahabuddeen. p. 367). Também, relativamente a essa mesma decisão, vide: CHAZOURNES, Laurence Boisson de. Les ordonnances en indication de mesures conservatoires dans l'affaire relative à L'application de la Convention
} 
Por fim, a sentença do "Caso La Grand" foi um marco na discussão da obrigatoriedade das medidas provisórias da CIJ. Na decisão final, a Corte foi incitada pela Alemanha a declarar se os Estados Unidos violaram ou não o Direito Internacional ao não cumprirem a ordem que determinava a suspensão da execução de um de seus nacionais pelo Estado americano do Arizona. Os argumentos oferecidos pelo Estado alemão foram: o princípio da efetividade, os pré-requisitos para adoção das medidas, o efeito obrigatório da decisão como uma necessária consequência da vinculação da sentença final, o art. 94 (1) da Carta da ONU, o art. 41 (1) do Estatuto da Corte e a prática do tribunal ${ }^{285}$.

O tribunal ressaltou então que, pela primeira vez em sua história, foi provocado a discutir os efeitos legais das medidas provisórias e, para tal, faria uma interpretação do art. 41 do Estatuto desde suas origens ${ }^{286}$. Aplicou como base o art. 31 da Convenção de Viena sobre o Direito dos Tratados que, em seu parágrafo primeiro, determina que um tratado deve ser interpretado de "boa fé segundo o sentido comum atribuível aos termos" e "em seu contexto e à luz de seu objetivo e finalidade"287.

Após analisar a interpretação dos termos, o histórico do dispositivo e sua relação com o art. 94 da Carta das Nações Unidas, a CIJ concluiu que as decisões que indicam as medidas cautelares tomadas com base no art. 41 do Estatuto possuem sim natureza obrigatória $^{288}$, e que os Estados Unidos violaram o Direito Internacional ao não acatarem a sentença na sua completude. Pacificou-se, assim, o grande debate doutrinário que, por décadas, girou em torno do assunto.

$\mathrm{Na}$ prática de outros tribunais internacionais a questão da obrigatoriedade das medidas cautelares não gerou polêmica. Isso se deve a vários fatores, dentre eles a terminologia aplicada aos estatutos e regulamentos ser mais clara quanto à vinculação das partes, ou simplesmente não terem registrado, ainda, casos de inobservância dessas decisões $^{289}$. É provável, também, que por serem tribunais estabelecidos durante ou após as

Pour la Prévention et la Repression du Crime de Génocide. Annuaire Français de Droit International. 1993, v. XXXIX. pp. 514-39.

${ }^{285}$ INTERNATIONAL COURT OF JUSTICE. La Grand Case (Germany v. United States of America). Judgment of 27 June 2001. p. 498.

${ }^{286}$ Id., ibid., p. 501.

${ }^{287}$ Convenção de Viena sobre o Direito dos Tratados, de 1969.

288 "In short, it is clear that none of the sources of interpretation referred to in the relevant Articles of the Viena Convention on the Law of Treaties, including the preparatory work, contradict the conclusions drawn from the terms of Article 41 read in their context and in the light of the object and purpose of the Statue. Thus, the Court has reached the conclusion that orders on provisional measures under Article 41 have biding effect." (INTERNATIONAL COURT OF JUSTICE. Op. cit., Judgment of 27 June 2001. p. 506).

${ }^{289}$ NAPOLITANO, Silvina S. Gonzáleas. Las medidas provisionales en Derecho Internacional ante las Cortes y Tribunales Internacionales. Buenos Aires: La Ley, 2004. p. 190. 
discussões supracitadas no seio da CIJ, tenham incorporado um entendimento melhor construído em suas normativas e jurisprudência.

No âmbito universal, o Tribunal Internacional para o Direito do Mar é um exemplo em que são encontradas as hipóteses supracitadas. A Convenção das Nações Unidas sobre o Direito do Mar (Convenção de Montego Bay) traz em seu art. 290 o que poderia ser um resumo do que já foi exposto até agora neste tópico. O parágrafo $1^{\circ}$ do referido dispositivo estabelece que o tribunal pode "decretar" medidas de caráter provisório em casos que seja competente a "prima facie ${ }^{\text {,290. }}$. Já o parágrafo $6^{\circ}$ determina que as partes devem "cumprir" as medidas "decretadas" "291. Igualmente, a jurisprudência do Tribunal, desde sua primeira decisão em sede de medida cautelar, já reforça o determinado pela Convenção ${ }^{292}$.

No âmbito regional também é pacífico o efeito obrigatório das medidas cautelares da Corte Interamericana de Direitos Humanos, muito embora não esteja tão obviamente estabelecido na Convenção Americana de Direitos Humanos. O art. 62, parágrafo $2^{\circ}$, expressa que a Corte "poderá tomar as medidas provisórias que considerar pertinentes." Não há, portanto, um termo que evidencie o caráter vinculante, contudo, a interpretação desse dispositivo juntamente com o art. 68 , parágrafo $1^{\circ}$, não deixa dúvidas quanto à obrigatoriedade dessas decisões ${ }^{293}$. Vale ressaltar que o mesmo raciocínio vale para as medidas de urgência decretadas de forma monocrática pelo presidente da Corte $^{294}$. A jurisprudência da Corte segue, por óbvio, o mesmo entendimento.

O Protocolo de Olivos traz a questão nos seus arts. 15 e 24, esse último regulado pela Resolução do Conselho do Mercado Comum n 23/04. Há a possibilidade de o Tribunal Permanente de Revisão ditar medidas provisórias e de caráter de urgência nos casos que estiverem sob sua jurisdição. Não há, até o momento, decisões proferidas, no

290 “'...] A court or tribunal with jurisdiction under UNCLOS has power to 'prescribe' provisional measures [...] The language of the Convention clearly demonstrates that the provisional measures ordered in UNCLOS disputes are binding as a matter of law." (KLEIN, Natalie. Dispute Settlement in the UN Convention on the Law of the Sea. Cambridge: Cambridge University Press, 2005. p. 60).

${ }^{291}$ CONVENÇÃO DAS NAÇÕES UNIDAS SOBRE O DIREITO DO MAR, art. 290.

292 INTERNATIONAL TRIBUNAL FOR THE LAW OF THE SEA. The M/V “Saiga" (n 2 ) Case. Request for provisional measures. Order of 11 March 1998.

293 “[...] Com efeito, a Convenção não apenas permite, mas também apoia as conclusões de que as sentenças baseadas no artigo 63 (2) são juridicamente obrigatórias. Como vimos, os textos em espanhol, francês e português da Convenção exigem que os Estados-Partes na Convenção cumpram as 'decisions' da Corte mais do que apenas seus 'judgments'. Ademais, o uso do termo 'judgment' no texto inglês do artigo 68 (1) parece ter sido uma tradução equivocada à qual não se pode associar qualquer significação legal. Desse modo, a linguagem da Convenção torna claro que decisões da Corte, e não só sentenças que são finais e inapeláveis, podem ser juridicamente obrigatórias para os Estados-Partes em um caso. Esse fato, somado às considerações de princípio discutidas acima, nos levam à conclusão de que as sentenças baseadas no artigo 63 (2) pertencem a esta categoria." (BUERGENTHAL, Thomas. Medidas Provisórias na Corte Interamericana de Direitos Humanos. Boletim da Sociedade Brasileira de Direito Internacional. Ano XLV-XLVI, dez. 1992/maio 1993, ns 84/86. pp. 11-36. p. 24).

${ }^{294}$ Em que pese a posição contrária de Buergenthal no trabalho anteriormente citado (Id., ibid., pp. 11-36). 
entanto, os termos ditar e ordenar - empregados tanto no Protocolo como na referida resolução, respectivamente, dão a entender a obrigatoriedade do decidido.

Outro efeito das medidas cautelares nos tribunais internacionais é que essas são provisórias. Dessa forma, persistem por um determinado período de tempo até serem modificadas, revogadas ou perderem a sua validade com a sentença final do caso. Mesmo quando não há previsão expressa no tratado ou regulamento, é possível ocorrer a modificação, revogação e suspensão dessas decisões, como acontece na prática da Corte Interamericana de Direitos Humanos ${ }^{295}$.

Finalmente, as medidas cautelares também possuem efeito de aplicação imediata em relação aos direitos internos. Uma vez emitidas, essas decisões devem ser de pronto efetivadas, até mesmo em razão de sua natureza protetiva e pelo fato de haver um comprovado risco iminente de dano irreparável a direito, prova, bens ou pessoas. Para tal, a parte em face da qual a medida foi estabelecida deve tomar as providências determinadas pelo tribunal internacional, o que pode implicar a prática de atos em todas as esferas do Estado, como a suspensão de um processo, a revogação de uma lei ou a prestação de um serviço.

\subsubsection{Pareceres e opiniões consultivas}

Nos ordenamentos jurídicos internos, a competência consultiva dos tribunais é matéria controversa. A Suprema Corte Americana, por exemplo, no início de sua história, recusou dar um parecer requisitado pelo presidente George Washington. Já o Tribunal Constitucional Alemão aboliu essa prática, em 1956, após uma desastrada decisão que quase derrubou um governo ${ }^{296}$. Já no plano internacional, praticamente todos os tribunais internacionais possuem a competência para dar pareceres e opiniões consultivas no âmbito de sua jurisdição.

As origens históricas do instituto remontam ao Pacto da Liga das Nações e à constituição da Corte Permanente de Justiça Internacional. O art. 14 do Pacto, in fine, estabelecia que a CPJI poderia dar "opiniões consultivas sobre qualquer disputa ou questão requisitada pelo Conselho ou pela Assembleia"297. Embora de vanguarda, essa proposição

\footnotetext{
${ }^{295}$ NAPOLITANO, Silvina S. Gonzáleas. Las medidas provisionales en Derecho Internacional ante las Cortes y Tribunales Internacionales. Buenos Aires: La Ley, 2004. p. 162-3.

${ }^{296}$ Mc WHINNEY, Edward. Judicial settlement of disputes: jurisdiction and justiciability. RCADI, 1990II, t. 221. pp. 9-194. pp. 54-5.

${ }^{297}$ No original: "[...] The Court may also give an advisory opinion upon any dispute or question referred to it by the Council or by the Assembly." (PACTO DA LIGA DAS NAÇÕES, art. 14).
} 
trouxe inúmeras dificuldades para sua implementação, o que quase colocou em risco a perduração dessas decisões ${ }^{298}$. As opiniões consultivas, entretanto, persistiram e tiveram uma relevância prática importantíssima para a jurisdição da CPJI. Entre 1922 e 1940 foram adotados 27 pareceres consultivos dos mais variados temas, os quais consistiram em "uma importante parte do trabalho judicial no período entre guerras" 299.

Posteriormente, com o advento da Organização das Nações Unidas, as opiniões consultivas foram mantidas na esfera jurisdicional da atual Corte Internacional de Justiça. A Carta das Nações Unidas, em seus arts 65 e 96, trouxe mudanças significativas em relação ao Pacto da Liga das Nações. O art. 96 dispõe em seu parágrafo $1^{\circ}$, que a Assembleia Geral e o Conselho de Segurança podem solicitar pareceres consultivos à CIJ "sobre qualquer questão de ordem jurídica." O parágrafo $2^{\circ}$, por sua vez, amplia significativamente o rol de legitimados, estabelecendo que outros órgãos das Nações Unidas "que forem em qualquer época devidamente autorizados pela Assembleia Geral", também podem fazer uso da competência consultiva, desde que a respeito de "questões jurídicas surgidas dentro da esfera de suas atividades"300.

Outros tribunais internacionais contemporâneos também possuem a competência consultiva em sua jurisdição. A Corte Interamericana de Direitos Humanos, por exemplo, encontra-se baseada no art. 64 da Convenção Americana sobre Direitos Humanos, e pode ser provocada pelos Estados-membros da $\mathrm{CADH}$ e pelos órgãos da Organização dos Estados Americanos, desde que dentro do exercício de suas competências. Os questionamentos têm alcance material amplo, podendo versar sobre todos os tratados de direitos humanos em vigor nos Estados americanos e sobre a compatibilidade de leis internas com a Convenção ${ }^{301}$. Outros tribunais regionais de direitos humanos, como a Corte Europeia e a Corte Africana, também admitem essa competência.

\footnotetext{
298 "La dernière phase de l'article 14 formule le principe de la competence simplement consultative de la Cour qui formera l'objet de ces leçons. La fonction consultative mérite un examen particulièrement attentif. En effet, si le principe et l'organisation de la compétence contentieuse de la Cour n'ont guère soulevé des difficultés sérieuses, il n'en est pas de même de sa compétence en matière d'avis. Celle-ci s'est heurtée, dès son instituition, à des objections de principe fort graves; con évolution enfin porte la marque d'hésitations compréhensibles et d'inévitables tâtonnements." (VISSCHER, Charles de. Les avis consultatifs de la Cour Permanente de Justice Internationale. RCADI, 1929-I, t. 26. pp. 1-76. pp. 5-6).

${ }^{299}$ ROSENNE, Shabtai. The Law and Practice of the International Court. Leyden: A. W. Sijthoff, 1965, v. II. p. 655.

${ }^{300}$ CARTA DAS NAÇÕES UNIDAS, art. 96.

${ }^{301}$ RAMOS, André de Carvalho. Processo Internacional de Direitos Humanos. Análise dos sistemas de apuração de violações de direitos humanos e a implementação das decisões no Brasil. São Paulo: Saraiva, 2012. p. 241.
} 
No âmbito dos tribunais regionais especializados dos blocos de integração, as opiniões consultivas também são rotineiramente utilizadas. O Tribunal Permanente de Revisão do Mercosul, por exemplo, poderá emitir opiniões consultivas sobre a interpretação das normas mercosulinas sempre que solicitado pelos Estados-parte, pelos órgãos decisórios do bloco e pelos tribunais superiores com jurisdição nacional, sendo observados os procedimentos específicos para cada caso ${ }^{302}$.

O art. 191 da Convenção das Nações Unidas sobre o Direito do Mar estabelece que a Câmara de Controvérsias dos Fundos Marinhos do Tribunal Internacional para o Direito do Mar emitirá pareceres quando requisitados pela Assembleia ou o Conselho da Autoridade. Nem o Estatuto, nem a Convenção fazem referências à competência consultiva do Tribunal como um todo. O Regulamento, no entanto, em seu art. 138, prevê essa possibilidade nos casos de acordos especiais que assim dispuserem dentro do âmbito de aplicação da Convenção. Embora contestado por parte da doutrina, esse artigo é considerado legítimo em caso de interpretação sistêmica da competência material do $\operatorname{ITLOS}^{303}$.

A prática dos tribunais internacionais, desde a implantação da CPJI até recentemente, demonstra uma importância significativa do exercício da competência consultiva. Questões fundamentais de Direito Internacional, como a personalidade jurídica das organizações internacionais, distribuição de poderes entre os órgãos das Nações Unidas, delimitação do conceito da autodeterminação dos povos ${ }^{304}$ e até mesmo o reconhecimento de Estados já foram discutidas em sede de opiniões consultivas ${ }^{305}$. Em razão disso, impõe-se neste capítulo um estudo mais aprofundado de sua natureza jurídica e dos seus efeitos.

\subsubsection{Natureza jurídica}

A natureza jurídica das opiniões consultivas é preocupação dos doutrinadores desde sua previsão no Pacto da Liga das Nações. Só na primeira década da Academia de Haia,

\footnotetext{
${ }^{302}$ REGULAMENTO DO PROTOCOLO DE OLIVOS, art. $2^{\circ}$.

${ }^{303}$ CHANDRASEKHARA, P. Rao ; GAUTIER, Ph. (editors) The rules of the International Tribunal for the Law of the Sea: a commentary. Leiden/ Boston: Martinus Nijhoff Publishers, 2006. p. 394.

304 Vide: CASELLA, Paulo Borba. Secessão no Direito Internacional e o Parecer Consultivo da Corte Internacional de Justiça sobre o Kosovo, de 22 de julho de 2010. Boletim da Sociedade Brasileira de Direito Internacional. Ano XCVIII, ago./dez. 2013, n 119-124, v. 1. pp. 111-26.

305 TOMUSCHAT, Christian. International Law: ensuring the survival of mankind on the eve of a new century. RCADI, 1999, t. 281. p. 422.
} 
três grandes estudos foram dedicados ao tema geral dos pareceres na CPJI, os quais servirão de ponto de partida deste tópico.

O primeiro foi elaborado por HUDSON, que questionou se a natureza jurídica das opiniões consultivas é de "função judiciária". Nesse sentido, faz uma análise quanto ao fato de serem decididas com base em um procedimento judiciário, de acordo com alguns requisitos essenciais, como: publicidade, possibilidade dos interessados de serem ouvidos, distância política dos juízes e decisão de questões jurídicas. Por fim, conclui que todas essas exigências estão presentes no processo de análise dos pareceres ${ }^{306}$.

Alguns anos depois, VISSCHER também se debruçou sobre o tema, de maneira mais ampla e crítica. Estruturou seu raciocínio partindo da premissa que os pareceres não são meras consultas desprovidas de qualquer obrigatoriedade. Pelo contrário, demonstrou que o procedimento consultivo, no seio da CPJI, envolvia a confirmação da jurisdição da Corte sobre os Estados interessados, a abertura para manifestação desses e de terem como objeto questões puramente jurídicas que depois, em sede contenciosa, não poderiam mais ser discutidos, pois cristalizariam um entendimento imune à realidade dos fatos ${ }^{307}$. Concluiu, assim, que a prática demonstrava uma crescente aproximação entre os procedimentos contenciosos e consultivos e indicou que essa seria a tendência ${ }^{308}$. Logo, a natureza jurídica dos pareceres, para o autor, é de uma decisão judicial internacional - às vezes até semelhante a uma sentença - porém desprovida de força executória ${ }^{309}$.

O terceiro estudo foi publicado por NÉGULESCO, que defendia existir, na prática, naturezas jurídicas diversas para os pareceres dados sobre questões e controvérsias, conforme o enunciado do art. 14 do Pacto da Sociedade das Nações. Os primeiros seriam apenas consultas, enquanto os demais seriam verdadeiras sentenças, só que não

\footnotetext{
${ }^{306}$ HUDSON, Manley O. Les avis consultatifs de la Cour Permanente de Justice Internationale. RCADI, 1925-III, t. 8. pp. 341-412. p. 408.

${ }^{307}$ VISSCHER, Charles de. Les avis consultatifs de la Cour Permanente de Justice Internationale RCADI, 1929-I, t. 26. pp.23-42, passim.

308 "[...] Sans doute, l'examen de cette évolution démontre en même temps une tendance à assimilation de la procédure consultative à la procédure contentieuse, tendance qui s'est traduite extérieurement par le souci toujours plus marqué chez la Cour d'entourer ses avis des garanties judiciaires habituelles. Les frontières n'en subsistent pas moins entre les deux activités de la Cour. Nous verrons plus loin qu'il est désirable de ne pas les effacer complètement." (Id., ibid., p. 51).

309 "Mais l'examen de la jurisprudence de la Cour nous révèle d'autres cas où la Cour a consenti, au contraire, à rendre en la forme d'avis et sur un véritable différend une décision qui, par la force des choses, a revêtu un caractère obligatoire pour les parties. Ce cas s'est présenté lorsque les Parties au litige ont volontairement assigné à l'avis de la Cour le caractère obligatoire d'une véritable sentence judiciaire. Nous sommes ici, ainsi qu'on l'a fait remarquer, en présence d'une méthode nouvelle de réglement pacifique des différends internationaux." (Id., ibid., p. 37).
} 
obrigatórias $^{310}$. O autor também afirma que, depois das reformas no Estatuto da CPJI, ficou clara a percepção de que quando a opinião consultiva tinha como objeto uma controvérsia, o procedimento adotado era análogo ao do contencioso, permitindo aos Estados interessados que se manifestassem e nomeassem juízes nacionais. Conclui seu estudo afirmando que a natureza jurídica dos pareceres é de uma sentença não obrigatória, entretanto, deixa a ressalva de que a prática já demonstrava sinais de uma intrínseca obrigatoriedade $\mathrm{e}^{311}$.

Como observado nas lições anteriores, a chave para a compreensão da natureza jurídica das opiniões consultivas está intrinsecamente ligada ao órgão que a prolatou - um tribunal internacional, e ao processo do qual essas são fruto - um processo decisório judicial, com a participação dos Estados interessados, publicidade e fundamentação no Direito Internacional. Estudos mais recentes também indicam um entendimento no sentido da função judicial das opiniões consultivas ${ }^{312}$. HIGGINS, por exemplo, enfatiza a questão da intervenção de terceiros interessados na elaboração dos pareceres, e relembra a sua fundamental participação em decisões recentes em sede consultiva na CIJ, evidenciando a existência de um processo decisório ${ }^{313}$.

Por fim, a questão da extensão do efeito obrigatório e suas dimensões, salvo melhor juízo, não parece afetar a natureza jurídica da decisão judicial internacional das opiniões consultivas. Ora, se prevista pelos meios cabíveis, fundada no poder jurisdicional do tribunal, tomada mediante um processo decisório e fundamentada no Direito Internacional, trata-se de uma decisão. Não obstante, o preciso alcance da vinculação dos pareceres e suas consequências no sistema jurídico internacional deve ser estudado de maneira mais atenta.

\footnotetext{
310 “.... En procédant à cet examen - et ceci se dégage, d'ailleurs, des leçons antérieures - nous constatons qu'il y a deux sortes d'avis, et qu'une distinction fondamentale sépare les avis sur 'point' des avis sur 'différend'; que si, au point de vue formel, tous les avis consultatifs, qu'ils soient sur 'point' ou sur 'différend', paraissent avoir la même nature juridique, car ils sont, tous, des consultations qui résultent des relations entre le Conseil ou l'Assemblée et la Cour, au point de vue réel, la nature juridique d'un avis sur point est différente de la nature juridique d'un avis sur différend; dans le premier cas, l'avis a le caractère d'une 'consultation juridique, sans carctère obligatoire' ; dans le deuxième cas, l'avis a les caractères d'une sentence non obligatoire, et même ce denier caractère tend à disparaître." (NÉGULESCO, Démètre. L'evolution de la procédure des avis consultatifs de la Cour Permanente de Justice Internationale. RCADI, 1936-III, t. 57. pp. 1-96. pp. 64-5).

${ }^{311}$ Id., ibid., pp. 78-80, passim.

312 Vide: ALJAGHOUB, Mahasen. The Advisory Function of International Court of Justice 1946-2005. Berlin-Heidelberg-New York: Springer, 2006.

${ }^{313}$ HIGGINS, Rosalyn. International Law and the avoidance, containment and resolution of disputes: general course on Public International Law. RCADI, 1991-V, t. 230. pp. 9-341. pp. 251-6, passim.
} 


\subsubsection{Efeitos}

Uma vez constatada que a natureza jurídica das opiniões consultivas é de decisão judicial internacional, importa analisar seus efeitos. A principal questão doutrinária se põe em razão da atribuição ou não do efeito obrigatório, ou seja, se atribuído, sua exata extensão e, por fim, se vincula ou não os sujeitos de Direito Internacional. Para esclarecer a referida questão, o primeiro ponto de análise é a fonte primária do efeito obrigatório: o poder jurisdicional. Logo, pergunta-se: é necessário que haja o reconhecimento da jurisdição pelo Estado interessado para que os tribunais internacionais emitam um parecer sobre questões que possam afetá-los?

Um dos casos paradigmáticos sobre a questão é o da Carélia Oriental, no qual a Corte Permanente de Justiça Internacional, por requisição do Conselho da Liga, deveria se pronunciar sobre a obrigatoriedade de certos dispositivos de um Tratado de Paz, de 1920, firmado entre Rússia e Finlândia. A grande questão era que o Estado Russo não fazia parte da Liga das Nações e, logo, não se submetia à jurisdição da CPJI. Para tal, o Pacto previa a possibilidade de Estados não membros se submeterem à Corte Permanente de Justiça Internacional, desde que consentido previamente, o que não foi observado, fazendo com que a Corte se recusasse a dar o parecer, alegando não possuir jurisdição ${ }^{314}$.

Essa posição, entretanto, não perdurou, pois o Estatuto da Corte Internacional de Justiça, em seu art. 65, trouxe uma redação considerada incompleta por ROSENNE. De acordo com o autor, há no referido dispositivo dois elementos que devem ser observados para o exercício da competência consultiva: a requisição deve ser feita por um órgão autorizado, e a questão deve versar sobre matéria jurídica. Assim, o Estatuto não se refere a um terceiro elemento, que seria o addressee do parecer. E conclui que aqui estaria a principal distinção das competências contenciosa e consultiva: o fato de que, na segunda, não há qualquer necessidade de consentimento dos Estados interessados para o pronunciamento da Corte ${ }^{315}$.

Consoante a posição anteriormente exposta é a jurisprudência da CIJ. Já no parecer sobre os Tratados de Paz, em 1950, a Corte foi enfática ao afirmar que a opinião consultiva

\footnotetext{
314 "Or, le consentement de la Russie n'a jamais été donné; par contre, elle a nettement et à maintes reprises déclaré qu'elle n'accepte aucune intervention de la Société des Nations dans son différend avec la Finlande. Les refus que la Russie avait déjà opposés aux démarches suggérées par le Conseil ont été renouvelés lorsque la requête d'avis lui a été notifiée. Par conséquent, la Cour se voit dans l'impossibilité d'exprimer un avis sur un différend de cet ordre." (COUR PERMANENTE DE JUSTICE INTERNATIONALE. Statut de la Carélie orientale. Avis consultatif du 23 juillet 1923. Série B, $\left.\mathrm{n}^{\circ} 05\right)$.

${ }^{315}$ ROSENNE, Shabtai. The law and practice of the international court. Leyden: A. W. Sijhoff, 1965, v. II. p. 698 .
} 
é dada ao órgão que requereu e não ao Estado interessado. Dessa forma, não caberia a alegação de que esse não se submeteu à sua jurisdição como um dado impeditivo ${ }^{316}$. Esse mesmo entendimento foi reforçado em outros pareceres, como o das Reservas à Convenção sobre o Genocídio (1951), o do Saara Ocidental (1975) e, mais recentemente, sobre as Consequências Legais da Construção de um Muro na Palestina e nos Territórios ocupados $(2004)^{317}$.

A partir daí foi reforçado o argumento, exposto pela própria Corte, de que as opiniões consultivas proferidas pela CIJ não vinculam os Estados, pois são proferidas para o órgão que as requereu e podem se referir a questões de interesse de Estados que não se submetem à sua jurisdição. Assim, não enseja em coisa julgada, podendo a questão ser novamente discutida em sede contenciosa, e não acarreta, à primeira vista, nenhuma obrigação aos interessados. Com exceção, é claro, daqueles casos em que esteja previamente estabelecido - em tratados ou acordos especiais - a estrita observância do que for decidido no parecer $^{318}$.

Embora não façam coisa julgada, o que permitiria a rediscussão dos mesmos fatos em sede contenciosa, é muito difícil que a Corte se posicione de maneira diversa do que foi decidido em sede de opinião consultiva. Ora, se no parecer um tribunal já indicar seu posicionamento referente a uma questão jurídica bem delimitada e fundada em uma controvérsia, é difícil que aquele mudará seu entendimento ao aplicá-la ao caso concreto $^{319}$.

316 "The consent of States, parties to a dispute, is the basis of the Court's jurisdiction in contentious cases. The situation is different in regard to advisory proceedings even where the Request for an Opinion relates to a legal question actually pending between States. The Court's reply is only of an advisory character: as such, it has no binding force. It follows that no State, whether a Member of the United Nations or not, can prevent the giving of an Advisory Opinion which the United Nations considers to be desirable in order to obtain enlightenment as to the course of action it should take. The Court's Opinion is given not to the States, but to the organ which is entitled to request it ; the reply of the Court, itself an 'organ of the United Nations', represents its participation in the activities of the Organization, and, in principle, should not be refused." (INTERNATIONAL COURT OF JUSTICE. Interpretation of peace treaties with Bulgaria, Hungary and Romania. Advisory Opinion of march $3^{\text {th }}, 1950$. p. 71).

${ }^{317}$ ALJAGHOUB, Mahasen. The advisory function of International Court of Justice 1946-2005. BerlinHeidelberg-New York: Springer, 2006. p. 100.

318 "It is clear beyond question that an advisory opinion, unless it is given compulsive effect by prior agreement, can give rise to no direct obligations on States [...].” (GREIG, D. W. The advisory jurisdiction of the International Court and the settlement of disputes between states. The International and Comparative Law Quarterly. April 1966, v. 15, pt. 2. pp. 325-68. p. 361).

319 "Mais, dans l'espèce que nous visons, cette façon de raisonner nous paraît en réalité purement théorique. Quand la Cour, par voie d'avis, a statué soit sur l'ensemble du différend, soit sur le point essentiel du différend, l'avis rendu a ici, exceptionnellement mais forcément, l'autorité de la chose jugée, en ce sens qu'il rend légalement certaine l'existence ou la non existence du rapport juridique qui fait l'objet de la contestation. Il en résulte que si la même question, entre les mêmes parties, était soumise ultérieurement à la Cour par la voie contentieuse, il ne serait plus possible à celle-ci de statuer autrement qu'elle l'a fait par 
$\mathrm{O}$ art. 66, caput, do Estatuto, determina a obrigação de notificar todos os seus Estados-parte para se manifestarem quando em face de uma requisição de opinião consultiva. Além disso, seu parágrafo $2^{\circ}$ autoriza a manifestação de outros Estados e organizações interessadas. Em sede jurisprudencial, até mesmo indivíduos já foram ouvidos, quando seus direitos estavam em pauta, como no parecer sobre os Tribunais Administrativos $(1956)^{320}$. Ademais, o art. 68 autoriza o uso de disposições próprias do procedimento contencioso, caso a Corte considere necessário, o que abriu as portas para a intervenção de terceiros interessados, com a aplicação analógica dos arts. $62^{321}$ e $63^{322}$ do mesmo documento. Por fim, desde o caso do Saara Ocidental, a Corte permitiu a indicação de juízes ad hoc em sede de parecer consultivo, mesmo sendo essa uma norma expressamente aplicável somente nos casos contenciosos ${ }^{323}$. Ora, se já é cristalizado que os pareceres carecem de efeito obrigatório, o que vincularia os Estados ao “determinado", por que tanta cautela em garantir que os interessados sejam ouvidos?

A resposta para tal pergunta se encontra no fato de que a autoridade das opiniões consultivas independe do efeito obrigatório, como nas outras decisões analisadas neste capítulo. Advém, segundo ALJAGHOUB, da "extensão da qual essa(s) cumprem consciente e persuasivamente sua obrigação de fornecer uma orientação jurídica para o órgão"324 requerente cumprir seus objetivos. Da mesma forma, HAMBRO conclui que se a questão formulada for clara quanto ao alcance desejado e a Corte não estiver conflituosamente dividida, pouco importa a discussão se um parecer é ou não vinculante,

voie d'avis : la Cour est ici exceptionnellement liée par sa décision antérieure." (VISSCHER, Charles de. Les avis consultatifs de la Cour permanente de justice internationale. RCADI, 1929-I, t. 26. p. 36).

${ }^{320}$ Ver GROSS, Leo. Participation of individuals in advisory proceedings before the international Court of Justice: question of equality between the parties. American Journal of International Law. January 1958, v. $52, \mathrm{n}^{\circ} 1$. pp. 16-40.

321 “Art. 62. 1) Quando um Estado entender que a decisão de uma causa é suscetível de comprometer um interesse seu de ordem jurídica, esse Estado poderá solicitar à Corte permissão para intervir em tal causa. 2) A Côrte decidirá sobre esse pedido.” (ESTATUTO DA CORTE INTERNACIONAL DE JUSTIÇA).

322 "Art. 63. 1) Quando se tratar da interpretação de uma convenção, da qual forem partes outros Estados, além dos litigantes, o Escrivão notificará imediatamente todos os Estados interessados. 2) Cada Estado assim notificado terá o direito de intervir no processo; mas, se usar deste direito, a interpretação dada pela sentença será igualmente obrigatória para ele.” (ESTATUTO DA CORTE INTERNACIONAL DE JUSTIÇA).

${ }^{323}$ HIGGINS, Rosalyn. International Law and the avoidance, containment and resolution of disputes: General Course on Public International Law. RCADI, 1991-V, t. 230. pp. 260-1.

324 "The authority of the Court does not depend upon the binding or non-binding nature of its opinions or its judgements. Rather, it is derived from the extent to which it fulfils conscientiously and persuasively its obligations to provide the necessary legal guidance to enable the requesting organs to carry out the objectives of the Organisation. Consequently, the opinion will be authoritative once it has served its purpose of providing guidance for the requesting organ and can be used for future action in the specified field [...]. "'(ALJAGHOUB, Mahasen. The advisory function of International Court of Justice 1946-2005. Berlin-Heidelberg-New York: Springer, 2006. p. 119). 
“pois este estará revestido de plena autoridade legal e significará um importante avanço para o desenvolvimento do Direito Internacional" 325 .

Em outros tribunais internacionais, a autoridade dos pareceres consultivos é ainda mais evidente. No caso da Corte Interamericana de Direitos Humanos, a competência consultiva pode ser invocada para interpretar os tratados de direitos humanos aplicáveis aos Estados Americanos e para analisar se uma lei interna é compatível com a Convenção Americana de Direitos Humanos. RAMOS explica que, no primeiro caso, são os denominados pareceres interpretativos e compõem o "controle de interpretação das normas" em abstrato. Já no segundo, os de compatibilidade formam o "controle de convencionalidade em abstrato estipulado pelo Pacto de San José" ${ }^{326}$. Em ambos os casos, contudo, a Corte pode declinar sua competência caso seja constatado que o parecer possa prejudicar potenciais casos na esfera contenciosa ${ }^{327}$.

RAMOS reforça a ideia da autoridade das opiniões consultivas ao afirmar que essas constituem a chamada "coisa interpretativa" que, embora não possua a vinculação da coisa julgada, firma o que é o Direito na esfera interamericana ${ }^{328}$. No caso dos pareceres de compatibilidade, por exemplo, quando em vista de uma resposta negativa, fica claro que o Estado legislador deve suspender a aplicação do diploma legal questionado, pois esse carece de validade e sua mera existência no ordenamento jurídico já implica em ato internacional ilícito ${ }^{329}$.

\footnotetext{
325 " [...] And if all these conditions are fulfilled, it does not matter much if the Opinion is characterised as 'binding' or not. It will be clothed with the full authority of the law and will signify an important contribution to the development of the law of nations. In that case, and in that case only, can it be expected that the political organs of the world community will accept the opinion in the real sense of the word 'acceptance'. In that case it is to be hoped and expected that the political organs will abstain from the untenable position of acting as a court of appeal against the legal advice tendered by the world's highest court." (HAMBRO, Edvard. The authority of the advisory opinions of the International Court of Justice. The International and Comparative Law Quartely. January 1954, v. 3, pt. 1. pp. 7-22. p. 22).

${ }^{326}$ RAMOS, André de Carvalho. Direitos humanos em juízo: comentários aos casos contenciosos e consultivos da Corte Interamericana de Direitos Humanos e o estudo da implementação dessas decisões no Direito Brasileiro. São Paulo: Max Limonad, 2001. pp. 345-6.

327 "La Corte entiende que una respuesta a las preguntas de Costa Rica, que podría traer como resultado una solución de manera encubierta, por la vía de la opinión consultiva, de asuntos litigiosos aún no sometidos a consideración de la Corte, sin que las víctimas tengan oportunidad en el proceso, distorsionaría el sistema de la Convención. El procedimiento contencioso es, por definición, una oportunidad en la que los asuntos son discutidos y confrontados de una manera mucho más directa que en el proceso consultivo, de lo cual no se puede privar a los individuos que no participan en éste. Los individuos son representados en el proceso contencioso ante la Corte por la Comisión, cuyos intereses pueden ser de otro orden en el proceso consultivo." (CORTE INTERAMERICANA DE DIREITOS HUMANOS. Compatibilidade de um Projeto de Lei com o Artigo 8.2.h. da Convenção Americana sobre Direitos Humanos. Opinião Consultiva OC12/91, de 6 de dezembro de 1991. Série A, n 12. p. 9).

${ }^{328}$ RAMOS, André de Carvalho. Op. cit., 2001, p. 347.

329 "Que la expedición de una ley manifiestamente contraria a las obligaciones asumidas por un Estado al ratificar o adherir a la Convención, constituye una violación de ésta y, en el caso de que esa violación afecte derechos y libertades protegidos respecto de individuos determinados, genera la responsabilidad
} 
No Tribunal Permanente de Revisão do Mercosul, a questão é um pouco mais complicada. Outros tribunais de blocos de integração econômica, como o Tribunal de Justiça da União Europeia e o Tribunal de Justiça da Comunidade Andina, são dotados da chamada interpretação prejudicial, ou seja, quando em face de um caso no qual normas comunitárias estejam em discussão, pode o juiz nacional pedir que o tribunal internacional competente se manifeste sobre o assunto, sendo a interpretação desse vinculante àquele $\mathrm{e}^{330}$. Esse não é o caso do TPR, pois o Protocolo de Olivos e seu regulamento adotaram a expressão opiniões consultivas para designar um procedimento semelhante ao da interpretação prejudicial e, como já discutido, a prática internacional tende a classificar essas decisões como não vinculantes ou não obrigatórias.

Esse impasse foi discutido logo na primeira vez que o TPR foi provocado por um tribunal nacional a dar sua opinião sobre a aplicação de normas mercosulinas a um caso concreto. Na Opinião Consultiva $\mathrm{n}^{\circ} 1$, de 2007 , requerida por uma juíza de primeira instância de Assunção no Paraguai, os árbitros discutiram o regime jurídico de seus pareceres e lamentaram o fato desses não possuírem os mesmos efeitos que uma interpretação prejudicial, enfatizando que a decisão que ali proferiam não era vinculante. Foi afirmado, entretanto, o fato de que um bloco de integração almeja interpretações uniformes de suas normativas, e o juiz nacional, ao consultar o tribunal internacional, objetiva justamente isso, sendo que a não vinculação colidiria de frente com esse pressuposto $^{331}$.

No final do parecer os árbitros declararam, por unanimidade, que "as opiniões consultivas peticionadas pelos órgãos judiciais nacionais devem ser consideradas como interpretações prejudiciais consultivas, na data ainda não vinculante", destacando que

internacional de tal Estado." (CORTE INTERAMERICANA DE DIREITOS HUMANOS. Responsabilidade Internacional por Expedição e Aplicação de Leis Violadoras da Convenção (Arts. $1^{\circ}$ e $2^{\circ}$ da Convenção Americana sobre Direitos Humanos). Opinião Consultiva OC-14/94, de 9 de dezembro de 1994. Série A, $\mathrm{n}^{\circ} 14$. pp.16-7).

${ }^{330}$ MENEZES, Wagner. Tribunais Internacionais: jurisdição e competência. São Paulo: Saraiva, 2013. p. 294.

331 "Por outro lado, no nosso regime atual, lamentavelmente a mal chamada opinião consultiva não é obrigatória nas circunstâncias precedentemente esboçadas, nem muito menos vinculante para o juiz nacional consultante. Em primeiro termo, é característica de todo tribunal sua imperatividade, mas, muito mais que isso, com um sistema não obrigatório, nem vinculante ao magistrado nacional, se desnaturaliza por completo o conceito, a natureza e o objetivo do que deve ser um correto sistema de interpretação prejudicial. Isso confronta, principalmente, com o objetivo da consulta do juiz nacional no âmbito de um processo de integração, que é lograr a interpretação da norma comunitária de maneira uniforme em todo o território integrado, objetivo por demais declarado pelo item quarto do artigo $2^{\circ}$ da Decisão CMC n ${ }^{\circ}$ 25/00 ("Art. $2^{\circ}$ Sem prejuízo da consideração de outros temas que pudessem ser propostos pelos Estados-Partes serão analisados os seguintes: [...] - Alternativas para uma interpretação uniforme da normativa Mercosul") que foi o antecedente do PO." (TRIBUNAL PERMANENTE DE REVISÃO DO MERCOSUL. Opinião Consultiva 1/2007. Parecer de 3 de abril de 2007. p. 5). 
caberia ao consultante a aplicação da interpretação dada pelo Tribunal. Ademais, afirmaram que as normas do Mercosul prevalecem sobre as dos direitos internos dos Estados $^{332}$. Em prevalecendo, portanto, a norma do bloco sobre a interna, fica claro que a interpretação do TPR possui autoridade para definir o direito que deverá ser aplicado pelo juiz interno.

Finalmente, apesar de escassa - uma vez que até hoje apenas uma opinião consultiva foi proferida - a prática do Tribunal Internacional para o Direito do Mar indica na mesma direção que os outros tribunais internacionais especializados aqui analisados. Ao responder um questionamento sobre as responsabilidades e obrigações dos Estados que patrocinam pessoas e entidades em atividades na chamada Área ${ }^{333}$, a Câmara de Fundos Marinhos foi enfática em suas declarações, utilizando-se de uma linguagem que inspira mais que meras recomendações, e sim uma verdadeira interpretação normativa, indicando precisamente quais são as referidas responsabilidades e obrigações dos Estados ${ }^{334}$.

Diante o exposto, resta a conclusão de que o efeito principal das opiniões consultivas reside em sua autoridade jurídica, que é proveniente de um processo decisório e resulta em um parecer que interpreta o Direito Internacional, esclarecendo seus contornos e servindo de instrumento fundamental ao desenvolvimento da matéria. Funda-se na função de jurisdictio das jurisdições internacionais e exerce um papel fundamental na sua construção e aperfeiçoamento. Ao clarificar o direito aplicável, essa decisão, por lógica, deve ser observada pelos Estados, sob pena desses incorrerem em atos ilícitos internacionais.

\subsubsection{Outras decisões}

2.2.4.1 Mandado de Prisão e entrega do Tribunal Penal Internacional e outros Pedidos de Cooperação de Tribunais Penais Internacionais

O Tribunal Penal Internacional é, certamente, uma das maiores conquistas civilizacionais da contemporaneidade. A constituição de um tribunal internacional

\footnotetext{
332 TRIBUNAL PERMANENTE DE REVISÃO DO MERCOSUL. Opinião Consultiva 1/2007. Parecer de 3 de abril de 2007. p. 36.

333 "Área significa o leito do mar, os fundos marinhos, e o seu subsolo além dos limites da jurisdição nacional." (CONVENÇÃO DAS NAÇÕES UNIDAS SOBRE O DIREITO DO MAR, art. $1^{\circ}$, parágrafo $1^{\circ}$, inciso I).

${ }^{334}$ SEABED DISPUTES CHAMBER OF THE INTERNATIONAL TRIBUNAL FOR THE LAW OF THE SEA. Responsabilities e obligations of States sponsoring persons and entities with respect to activities in the Area. Advisory Opinion, 1 February 2011. List of cases $n^{\circ} 17$.
} 
permanente competente para processar e julgar os indivíduos responsáveis pelos piores crimes internacionais foi um grande desafio. Hoje, seu pleno funcionamento traz uma série de problemas a serem resolvidos. Um deles é a observância e execução de suas decisões, que sempre dependerão da cooperação dos Estados.

O Estatuto de Roma, em seu art. 86, estabelece um dever geral de cooperação ${ }^{335}$ por meio do qual os Estados-partes devem "cooperar plenamente" com o Tribunal "no inquérito e no procedimento". Essa cooperação se operacionaliza por pedidos, conforme previsto nos arts. 87 a 99 do referido Estatuto, que se revestem em forma de decisões judiciais do TPI e geram efeitos externos, na medida em que dependem da ação dos Estados para serem efetivadas. Em razão disso, as partes do Estatuto devem implementar uma legislação adequada em seus direitos internos para facilitar o cumprimento desses $\operatorname{pedidos}^{336}$.

Dentre os pedidos de cooperação, um dos mais importantes para a realização da efetividade do próprio Tribunal é o mandado de detenção e entrega de pessoas. $\mathrm{O}$ art. 89 do Estatuto de Roma determina que, uma vez recebida a requisição, o Estado-parte no qual a pessoa procurada se encontrar, deve detê-la e entregá-la ao Tribunal. Esse dever foi alvo de grandes discussões no Comitê Preparatório do Estatuto, contudo, permaneceu no texto final, restando uma indiscutível obrigação às partes ${ }^{337}$.

Outros pedidos de cooperação do Tribunal Penal Internacional referem-se à identificação de pessoas ou objetos, reunião de elementos de provas, interrogatório de pessoas, notificação de documentos, exumação de cadáveres, buscas e apreensões, proteção de vítimas e testemunhas, localização e arresto de bens, etc, conforme o estabelecido no art. 93 do Estatuto.

O Tribunal pode, a qualquer tempo, suspender a execução de um pedido de cooperação, conforme o disposto nos arts. 94 e 95 do Estatuto, o que aproxima a sua natureza com a da medida cautelar internacional, pois ambos são obrigatórios, geram efeitos externos e podem ser temporários, de acordo com a decisão do juízo. A sua

\footnotetext{
${ }^{335}$ Vide: CIAMPI, Annalisa. The obligation to cooperate. In: CASSESE, Antonio; GAETA, Paola; JONES, John R. W. D. (Eds.). The Rome Statute of the International Criminal Court: a commentary. New York: Oxford University Press, 2009, v. II. pp. 1607-38.

336 "Os Estados-Partes deverão assegurar-se de que o seu direito interno prevê procedimentos que permitam responder a todas as formas de cooperação específicas neste capítulo." (ESTATUTO DE ROMA DO TRIBUNAL PENAL INTERNACIONAL, art. 88).

337 "The fairly rigid obligation of States Parties to surrender under article 89 para. 1 resulting from the foregoing considerations may be seen as a focal point in a long historical evolution towards what has been called 'a duty to extradite for international crimes' in the state to state context." (TRIFFTERER, Otto. Commentary on the Rome Statue of International Criminal Court. Observer's Notes, Article by Article. $2^{\text {nd }}$. ed. Münich: C. H. Beck - Hart - Nomos, 2008. p. 1540).
} 
comunicação pode se dar tanto pela via diplomática, como por qualquer outra que o Estado-parte venha a indicar ${ }^{338}$.

De acordo com o relatório enviado à Assembleia Geral da ONU em agosto de 2013, só no período de $1^{\circ}$ de agosto de 2012 a 31 de julho de 2013 o Tribunal enviou aos Estados-membros 220 pedidos de cooperação ${ }^{339}$. A título de comparação, no ano de 2011 foram 496 pedidos e 12 mandados de prisão expedidos ${ }^{340}$. Isso demonstra, em números, a importância do devido cumprimento desses pedidos cooperacionais para o pleno desenvolvimento da jurisdição internacional penal. Nessa esteira, também os tribunais penais internacionais ad hoc podem requisitar pedidos cooperacionais semelhantes aos supracitados. Nesse caso, o que obriga os Estados ao dever de cooperar é o fato de que a jurisdição desses tribunais se funda em resoluções vinculantes do Conselho de Segurança, possuindo, portanto, eficácia erga omnes.

2.2.4.2 Pronta Libertação de Embarcações e Tripulações do Tribunal Internacional para o Direito do Mar

A Pronta Libertação de Embarcações e Tripulações (Prompt Release of Vassels and Crews) é um procedimento especial dentro da esfera de jurisdição obrigatória do Tribunal Internacional para o Direito do Mar. É cabível quando a embarcação com bandeira de um Estado-Parte for detida por outro Estado-Parte, não cumprindo com o estabelecido na Convenção das Nações Unidas sobre o Direito do Mar, no que tange à pronta libertação da embarcação ou de sua tripulação, mediante a prestação de caução ou garantia financeira ${ }^{341}$. Trata-se, em última instância, de uma garantia da livre navegação oferecida pela Convenção, uma vez que concedeu inúmeras hipóteses em que o Estado costeiro pode exercer sua jurisdição além de seu mar territorial ${ }^{342}$.

O Tribunal será competente para adjudicar um caso de Pronta Libertação se forem preenchidas três condições. A primeira é que tanto o Estado de bandeira da embarcação, quanto o Estado que o deteve, sejam partes da Convenção de Montego Bay. Caso não sejam, poderão consentir para tal. A segunda estabelece um período de 10 dias para que as

\footnotetext{
${ }^{338}$ ESTATUTO DE ROMA DO TRIBUNAL PENAL INTERNACIONAL, art. 87, parágrafo $1^{\circ}$, alínea "a”. ${ }^{339}$ UNITED NATIONS. Report of the International Criminal. General Assembly. (A/68/314). 13 august 2013. p. 21.

${ }^{340}$ UNITED NATIONS. Report of the International Criminal Court. General Assembly (A/67/308). 14 august 2012. p. 20.

${ }^{341}$ CONVENÇÃO DAS NAÇÕES UNIDAS SOBRE O DIREITO DO MAR, art. 292, parágrafo $1^{\circ}$.

${ }^{342}$ KLEIN, Natalie. Dispute Settlement in the UN Convention on the Law of the Sea. Cambridge: Cambridge University Press, 2005. p. 86.
} 
partes concordem em resolver a questão em outro tribunal. Transcorrido o prazo e não havendo acordo, o caso poderá ser levado à jurisdição do ITLOS. Finalmente, a terceira condição diz respeito à nacionalidade da embarcação, sendo necessária a constatação de que essa é a mesma que a do Estado que iniciou os procedimentos ${ }^{343}$.

Interessante destacar que o procedimento de Pronta Libertação pode ser iniciado perante o Tribunal do Mar mesmo que ações sobre a embarcação, seu armador ou tripulação estejam em curso nos judiciários domésticos ${ }^{344}$. Essa "natureza paralela" já foi questionada por implicar em litispendência, abuso de direito e até mesmo desconsideração do princípio do prévio esgotamento dos recursos internos para acionamento da jurisdição internacional $^{345}$. O procedimento, entretanto, se dá "sem prejuízo do mérito" de qualquer litígio que esteja em andamento nos tribunais internos.

O procedimento tem caráter de urgência, como estabelece o art. 292, parágrafo $3^{\circ}$ da Convenção, e o art. 112 do Regulamento do Tribunal. Difere, contudo, da medida cautelar, uma vez que não se trata de um incidente processual ${ }^{346}$, ou de uma decisão interlocutória. Trata-se, isso sim, de um procedimento especial aplicável a casos específicos e que culmina em uma decisão final e obrigatória, como prevê o parágrafo $4^{\circ}$ do referido dispositivo. Até dezembro de 2012, dos 22 casos submetidos ao Tribunal, nove foram de Pronta Libertação, incluindo o primeiro caso, julgado em 4 de dezembro de $1997^{347}$.

\subsection{OBSERVÂNCIA E EXECUÇÃO DAS DECISÕES JUDICIAIS INTERNACIONAIS: RULE OF LAW NA ERA DOS TRIBUNAIS}

Todas as decisões judiciais internacionais analisadas anteriormente possuem um traço comum: vinculam os sujeitos de Direito Internacional - seja por força obrigatória ou em razão de sua autoridade - e demandam uma aplicabilidade imediata. As partes no processo internacional devem cumprir essas decisões sob pena de cometer um novo ilícito internacional e frustrar a finalidade essencial das jurisdições internacionais, isto é, a resolução pacífica da controvérsia com base no Direito, logo, o fortalecimento da justiça no plano internacional.

\footnotetext{
${ }^{343}$ CHANDRASEKHARA, P. Rao; GAUTIER, Ph. (Eds.). The rules of the International Tribunal for the Law of the Sea: a commentary. Leiden/Boston: Martinus Nijhoff Publishers, 2006. p. 307.

${ }^{344}$ CONVENÇÃO DAS NAÇÕES UNIDAS SOBRE O DIREITO DO MAR, art. 292, parágrafo $3^{\circ}$.

345 KLEIN, Natalie. Dispute Settlement in the UN Convention on the Law of the Sea. Cambridge: Cambridge University Press, 2005. p. 97.

${ }^{346}$ CHANDRASEKHARA, P. Rao; GAUTIER, Ph. (Eds.). Op. cit., 2006, p. 306.

${ }^{347}$ Informação disponível em: <http://www.itlos.org>. Acesso em: 10 dez. 2013.
} 
Caso uma parte, contudo, se recuse a cumprir ou efetivar uma decisão judicial internacional, quais são as ferramentas de que o Direito Internacional dispõe para fazer valer as ordens dos tribunais internacionais? Na década de 60, um artigo publicado por SCHACHTER, no American Journal of International Law, propõe os seguintes métodos de enforcement das decisões judiciais e arbitrais internacionais: I) pressão diplomática e econômica; II) confisco dos bens pertencentes ao Estado devedor; III) uso de forças armadas; IV) o enforcement pelas organizações internacionais; e V) o enforcement pelas cortes domésticas $^{348}$. Qual seria, então, o método mais adequado ao contexto do Direito Internacional contemporâneo?

Do ponto de vista histórico, a partir da prática da arbitragem internacional, desde as Conferências para Paz de Haia houve uma especial preocupação em resguardar o devido cumprimento e consequente efetividade do que seria decidido pelos árbitros. $\mathrm{O}$ art. 18 da Convenção sobre Resolução Pacífica de Controvérsias de 1899 e o art. 37 da de 1907 trazem a mesma redação, segundo a qual o recurso a arbitragem "implica o compromisso de se submeter de boa fé à sentença" 349 .

Isso não significa, no entanto, que todos os laudos arbitrais tenham sido cumpridos. Ao deparar-se com a impossibilidade de efetivar o previsto no dispositivo, as partes sucumbentes desenvolveram a teoria de que, diante da existência de certas nulidades, a execução da decisão poderia ser suspensa. Trata-se, como afirmado supra, das primeiras tentativas de mitigação do efeito definitivo das decisões judiciais internacionais. O que motivava tais argumentos eram, quase sempre, alegações de nulidade do compromis, o excesso de poder do tribunal ${ }^{350}$ arbitral, corrupção de membros, não observância de regras procedimentais, etc ${ }^{351}$.

\footnotetext{
${ }^{348}$ SCHACHTER, Oscar. The enforcement of International Judicial and Arbitral Decisions. The American Journal of International Law, 1960, v. 54, pp. 1-24.

${ }_{349}$ VULCAN, Constantin. L'exécution des décisions de la Cour Internationale de Justice d'après la Charte des Nations Unies. Revue Générale de Droit Internationale Public, 1947, t. XVIII, v. 51. pp. 187205. p. 187.

${ }^{350}$ Nesse contexto: "Commettre un excès de pouvoir, si le mot pouvoir est interprété dans le sens de la faculté de lier, ne saurait signifier autre chose qu'acomplir un acte qui est sans effet obligatoire, sans validité." (CASTBERG, Frede. L'excès de pouvoir dans la justice internationale. RCADI, t. 35, 1931-I, pp. 353-472. p. 360).

351 "An abundant literature has grown up on the excuses for non-performance. The principles of nullity and impossibility are universally recognized, but there is a variety of views on the specific conditions of their application. Three conditions are most generally formulated in this literature as grounds of nullity: (1) excess of power, (2) corruption of a member of the tribunal, or (3) a serious departure from a fundamental rule of procedure. In practice, it is the first-excess of power - which is the most likely formula to be asserted for justifying non-performance." (SCHACHTER, Oscar. The enforcement of International Judicial and Arbitral Decisions. The American Journal of International Law, 1960, v. 54, pp. 1-24. p. 3).
} 
Assim, diante do não cumprimento de um laudo arbitral pela parte sucumbente, a parte vitoriosa dispunha de um rol de sanções que poderia aplicar discricionariamente, dentre elas: rompimento de relações diplomáticas, denúncia de convenções comerciais, represálias e, até mesmo, a guerra. Esses meios de se fazer cumprir a decisão, no entanto, eram, obviamente, mais efetivos aos Estados mais fortes, enquanto, aos mais fracos, cabia só o conformismo ${ }^{352}$.

Com o advento do Pacto da Sociedade das Nações e do - ainda que frágil - sistema de segurança coletiva, uma alternativa surgiu para balancear a desigualdade entre os Estados, quando em face do descumprimento de uma decisão internacional: o recurso ao Conselho da Sociedade das Nações. O art. 13 do referido Pacto, ao tratar da solução de controvérsias pela via jurídica, ressalta em seu inciso $4^{\circ}$, a necessidade de os Estadosmembros daquela organização "executar de boa fé as sentenças" e "não recorrer à guerra". Caso não houvesse o cumprimento espontâneo, o Conselho se encarregaria, proprio motu, de propor as medidas para "assegurar seu efeito" 353 .

Com o advento da Organização das Nações Unidas ficou consolidado que o uso da força unilateral não seria mais permitido no caso do não cumprimento das decisões dos tribunais internacionais. Mais especificamente, em relação às decisões da Corte Internacional de Justiça ${ }^{354}$, a Carta da ONU possibilita, em seu art. $94^{355}$, o recurso ao Conselho de Segurança. Importa ressaltar que, de maneira nenhuma, o Conselho é obrigado a agir, sendo necessário que a parte o provoque, e as medidas cabíveis só serão adotadas de acordo com as regras procedimentais do órgão ${ }^{356}$. Ou seja, há a possibilidade de recurso para se fazer valer a sentença, mas a decisão será política e discricionária.

\footnotetext{
${ }^{352}$ VULCAN, Constantin. L'exécution des décisions de la Cour Internacionale de Justice d'après la Charte des Nations Unies. Revue Générale de Droit Internationale Public, 1947, t. XVIII, pp. 187-205. p. 188.

353 "Les Membres de la Société s'engagent à exécuter de bonne foi les sentences rendues, et à ne pas recourir à la guerre contre tout Membre de la Société qui s'y conformera. Faute d'exécution de la sentence, le Conseil propose les mesures qui doivent en assurer l'effet." (PACTO DA SOCIEDADE DAS NAÇÕES, art. 13 , inciso $4^{\circ}$ ).

${ }^{354}$ Muito embora não seja explícito, entende-se, como demonstrado supra, que o art. 94 da Carta das Nações Unidas não se refere única e exclusivamente às sentenças da Corte Internacional de Justiça, mas a todas as decisões tomadas por esse tribunal. Ao contrário do seu antecessor, o Pacto da Sociedade das Nações, que no seu art. 13 (4), possuía uma redação ampla da qual poderia se inferir que qualquer tribunal, judicial ou arbitral, seria abarcado.

355 “Art. 94 - 1. Cada Membro das Nações Unidas se compromete a conformar-se com a decisão da Corte Internacional de Justiça em qualquer caso em que for parte; 2 . Se uma das partes num caso deixar de cumprir as obrigações que lhe incumbem em virtude de sentença proferida pela Corte, a outra terá direito de recorrer ao Conselho de Segurança que poderá, se julgar necessário, fazer recomendações ou decidir sobre medidas a serem tomadas para o cumprimento da sentença." (CARTA DAS NAÇÕES UNIDAS).

356 KELSEN, Hans. The Law of United Nations: a critical analysis of its fundamental problems. New Jersey: The Lawbook Exchange, LTI, 2000. p. 539.
} 
No âmbito europeu, em abril de 1957, foi concluída a "Convenção Europeia pela Solução Pacífica de Controvérsias" que determina a submissão à Corte Internacional de Justiça de todas as controvérsias "relevantes em matéria de direito internacional" entre os membros do Conselho da Europa. Em seu art. 39 dispõe que: todas as partes devem cumprir com as sentenças da CIJ ou com os laudos arbitrais de litígios que tenham sido partes e, no caso de não o fazer, poderá a outra parte recorrer ao Comitê de Ministros do Conselho Europeu que decidirá, por maioria qualificada de dois terços, as recomendações cabíveis à parte sucumbente para assegurar a realização da sentença ou laudo ${ }^{357}$.

A partir desse quadro, surge uma questão relevante no centro da problemática da execução e da observância das decisões judiciais internacionais. Grande parte da doutrina e da jurisprudência internacional faz uma distinção entre a obrigatoriedade e a executoriedade dessas decisões. Tradicionalmente, a função de dar o provimento jurisdicional pertence ao órgão judiciário e a sua execução ao executivo ${ }^{358}$. Tendo em vista que o sistema internacional não possui uma estrutura centralizada capaz de exercer a função executiva, as decisões judiciais internacionais são obrigatórias, porém, podem padecer pela falta de executoriedade.

Essa problemática fez com que muitos doutrinadores e a própria jurisprudência dos tribunais internacionais delegassem a questão da execução à esfera da política. TUNCEL, ao tratar especificamente da execução das sentenças da Corte Internacional de Justiça, afirmou que a executoriedade traz consigo um "germe para um novo conflito inteiramente diferente daquele resolvido pela sentença". E conclui que no Direito Internacional, a separação da sentença e sua execução constituem um postulado essencial do contencioso internacional $^{359}$.

GIARDINA explica que, na visão clássica, a questão da obrigatoriedade e da executoriedade das sentenças internacionais se sustenta em dois pontos fundamentais. De um lado, a distinção entre o papel do juiz e do agente executivo e, do outro, as limitações impostas aos tribunais internacionais em virtude da cláusula de atribuição da jurisdição,

\footnotetext{
357 SALMON, Jean. La Convention Européenne pour le Réglement Pacifique des Différends. Revue Générale de Droit International Public, 1959, n. 63. pp. 21-64. p 26-30, passim.

358 "The function of enforcing a decision of an international tribunal is an executive function, and as such it should be confined to a body which is invested with executive powers. It becomes, in this event, a political as distinguished from a judicial matter." (HUDSON, Manley O. International Tribunals past and future. Washington: Carnegie Endowment for International Peace and Brookings Institution, 1944. p. 128).

${ }^{359}$ TUNCEL, E. L'execution des décisions de la C.I.J. selon la Charte des Nations-Unies. Thèse: Nêuchatel, 1960. p. 59.
} 
que deve ser interpretada restritivamente, deixando aos Estados a discricionariedade no modo de cumprimento dessas decisões ${ }^{360}$.

Em contraponto, ROSENNE pondera que, se por um lado, a execução das decisões não faz parte da esfera judiciária internacional, e sim do domínio político, por outro os tribunais internacionais não podem e nem devem "visualizar a eventualidade de suas decisões não serem executadas." E conclui que o problema do não cumprimento das decisões judiciais internacionais é um aspecto particular da questão geral da não observância de decisões dos órgãos competentes da comunidade internacional. Segundo o autor, trata-se de um problema "não unicamente político; constitui $o$ problema político supremo que se põe perante a humanidade" ${ }^{361}$. Por fim, afirma categoricamente, que o argumento segundo o qual um litígio se torna mais político que jurídico, pois uma das partes pode se recusar a aceitar o decidido, é "uma simplificação extrema que serve para deslocar inoportunamente a tônica do mérito do problema"362.

Em que pese a autoridade do argumento segundo o qual a executoriedade das decisões internacionais pertence à esfera discricionária dos Estados, uma breve análise dos tratados constitutivos dos tribunais internacionais e de suas jurisprudências mostra que esse argumento não encontra guarida na prática contemporânea do Direito Internacional.

Apesar de escassa e tímida, a prática da CPJI fornece bases suficientes para uma conclusão. Somente no caso relativo à Sociedade Comercial da Bélgica é que a Corte Permante de Justiça se expressou diretamente no sentido de que uma decisão internacional, no caso um laudo arbitral ou sentença, deve ser executado tal como foi pronunciado ${ }^{363}$. Posteriormente, no Caso Mavrommatis a mesma Corte considerou não ser necessário se pronunciar sobre sua competência para julgar casos de não execução ${ }^{364}$.

\footnotetext{
360 GIARDINA, Andrea. La mise en oeuvre au niveau national des arrêtes e des décisions internationaux. RCADI, 1979-IV, t. 165. pp. 233-352. pp. 247-8.

361 "On ne peut pas nier qu'au fond, le problème qui consiste à assurer l'exécution des décisions de la Cour ne soit qu'un aspect particulier du problème plus général qui est celui d'assurer l'exécution des décisions des organes compétents de la Communauté internationale. Ce problème lá n'est pas uniquement un problème politique; il constitue le problème politique suprême qui se pose devant l'humanité. Ne pas se conformer à une décision de la Cour ayant force obligatoire est un phénomene désolant comme le serait la défaillance à se conformer à la décision de tout autre organe compétent pour pendre des décisions obligatoires vis-à-vis des Etats." (ROSENNE, Shabtai. L'exécution et la mise en vigueur des décisions de la Cour Internationale de Justice. Revue Générale de Droit International Public, 1953, t. LVII. pp. 532- 83. pp. 537-8).

${ }_{362}$ Id., ibid., p. 539.

${ }^{363}$ COUR PERMANENTE DE JUSTICE INTERNATIONALE. Société Comerciale de Belgique. Arrêt du 15 juin 1939. Série A/B, n ${ }^{\circ}$ 78. p. 176.

${ }^{364}$ COUR PERMANENTE DE JUSTICE INTERNATIONALE. Affaire des Concessions Mavrommatis en Palestine (Réadaptation). Arrêt du 10 octobre 1927. Série A, nº11. p. 14.
} 
$\mathrm{Na}$ CIJ, quando julgado o caso Haya de La Torre, a Corte se recusou a responder a demanda formulada pelos governos da Colômbia e do Peru sobre como o julgado deveria ser executado $^{365}$, enfatizando a posição de sua antecessora de que sua jurisdição se limita à atividade adjudicativa. Recentemente, porém, alguns casos demonstram uma mudança na prática do tribunal. No Caso da Disputa de Fronteira entre Burkina Faso e Mali, a Corte, pela primeira vez, assumiu um papel direto na implementação da sua sentença. Para tal, foi formada uma câmara $a d$ hoc que possuía a atribuição de nomear especialistas para ajudar as partes na demarcação da fronteira de acordo com o estabelecido na sentença final ${ }^{366}$. Mais recentemente, no Caso Projeto Gabcíkovo-Nagymaros, a Corte entendeu que há sim a obrigação jurídica de cumprimento de suas sentenças, e que para tal as partes poderiam requisitar à Corte a indicação dos meios cabíveis ${ }^{367}$.

Dentre os tribunais especializados, sejam regionais ou universais, o dever de cumprir com as decisões é nítido e claro em seus estatutos, o que os difere é o controle. Em alguns casos, os tribunais criam mecanismos próprios de supervisão; em outros, órgãos políticos são encarregados da tarefa. É comum, também, deixar essa tarefa para os tribunais domésticos ou estabelecer mecanismos de contra-medidas para que as próprias partes, dentro de uma margem de legalidade constante no tratado constitutivo ou no regulamento, possam forçar o adimplemento.

A Convenção Europeia de Direitos Humanos, por exemplo, delega expressamente ao Comitê de Ministros do Conselho Europeu a supervisão do cumprimento das sentenças da Corte Europeia de Direitos Humanos ${ }^{368}$. O Comitê deve, assim que lhe for transmitida a decisão, inscrevê-la na ordem do dia e convidar o Estado interessado a informar sobre as medidas - individuais e gerais - tomadas para a devida reparação, ou se foi efetuada a "satisfação equitativa". A parte lesada pode, a qualquer momento, comunicar o seu não cumprimento. Caso o Estado não cumpra a decisão, caberá ao Comitê indicar as medidas necessárias para sua efetivação ${ }^{369}$.

\footnotetext{
${ }^{365}$ INTERNATIONAL COURT OF JUSTICE. Haya de la Torre Case (Colombia/Peru). Judgment of 13 june 1951. p. 78.

366 INTERNATIONAL COURT OF JUSTICE. Case Concerning the Frontier Dispute (Burkina Faso/Republic of Mali). Judgment of 22 december 1986. p. 558.

${ }^{367}$ INTERNATIONAL COURT OF JUSTICE. Case Concerning the Gabcikovo-Nagymaros Project (Hungary/Slovakia). Judgment of 25 september of 1997. p. 9.

${ }^{368}$ RAMOS, André de Carvalho. Processo Internacional de Direitos Humanos. Análise dos sistemas de apuração de violações de direitos humanos e a implementação das decisões no Brasil. São Paulo: Saraiva, 2012. p. 160.

${ }^{369}$ BARRETO, Irineu Cabral. A Convenção Europeia dos Direitos do Homem Anotada. 3. ed. rev. e atualizada. Coimbra: Coimbra Ed., 2005. pp. 459-62, passim.
} 
Importante destacar que a chamada "satisfação equitativa" é um mecanismo pelo qual o sistema europeu permite aos Estados uma "válvula de escape", decorrente da obrigatoriedade da sentença da Corte Europeia de Direitos Humanos. Tal mecanismo consiste em facultar aos Estados que declaravam não poder reparar o dano reconhecido pela Corte, a conversão da pena em dinheiro a ser pago às vítimas. Atualmente, a situação vem mudando. Em alguns casos, o tribunal indicou medidas para o cumprimento do decidido, verdadeiras obrigações de fazer, emprestando o caráter condenatório a suas decisões e efetivando, de fato, a reparação ao dano provocado pelo ato ilícito internacional, medida considerada cara à proteção internacional dos direitos humanos ${ }^{370}$.

A Corte Interamericana de Direitos Humanos entendeu que a fiscalização do devido cumprimento de suas decisões é parte de suas competências. Para tanto, desenvolveu um mecanismo periódico de supervisão no qual os próprios juízes interamericanos avaliam se suas determinações foram ou não cumpridas ${ }^{371}$. A fundamentação jurídica para tal é o princípio do pacta sunt servanda e o art. 27 da Convenção de Viena sobre o Direito dos Tratados de 1969, aplicados à interpretação do art. 68 (1) da Convenção Americana de Direitos Humanos, que estabelece o dever de cumprimento de suas decisões por parte dos Estados. Constatado o não cumprimento integral ou parcial do decidido, o tribunal encaminha o caso para a Assembleia Geral da Organização dos Estados Americanos, como determina o art. 65 da Convenção Americana de Direitos Humanos ${ }^{372}$.

No âmbito da Organização Mundial do Comércio, a observância das decisões do Órgão de Apelação do sistema de solução de controvérsias é garantido com um mecanismo de contramedidas. Uma vez adotado o relatório, a parte vencida deve suspender a medida que causou o litígio, podendo o Órgão sugerir os meios pelos quais devem-se implementar as recomendações - o que deve ser feito, se não imediatamente, em um período razoável de tempo. Se o relatório não for cumprido, a parte sucumbente deve oferecer uma compensação, devida não somente à parte vencedora, mas a todos os membros da OMC. Caso a compensação não seja oferecida, a parte vitoriosa deve pedir autorização para aplicar as contramedidas equivalentes a fim de nulificar a violação ou equilibrar as relações, que consistem na suspensão das obrigações e concessões adquiridas em virtude

\footnotetext{
${ }^{370}$ RAMOS, André de Carvalho. Processo Internacional de Direitos Humanos. Análise dos sistemas de apuração de violações de direitos humanos e a implementação das decisões no Brasil. São Paulo: Saraiva, 2012. pp. 171-8, passim.

371 CANÇADO TRINDADE, Antônio Augusto. El ejercicio de la función judicial internacional. Memórias de La Corte Interamericana de Derechos Humanos. Belo Horizonte: Del Rey, 2011. p. 144.

372 GARCIA, Fernando Silva. Derechos humanos: efectos de las sentencias internacionales. Ciudad del Mexico: Editorial Porrúa, 2007. p. 47.
} 
dos acordos comerciais. A concessão dessa autorização é quase automática, apenas não sendo possível se houver um consenso negativo contra isso, o que é praticamente impossível. Ademais, o sistema de solução de controvérsias monitora o cumprimento dos relatórios e, se houver desentendimento quanto a sua plena implementação ou não, o Órgão de Apelação pode ser chamado a analisar o caso. Por fim, se houver desacordos quanto às contramedidas adotadas, a disputa pode ser resolvida pela arbitragem ${ }^{373}$.

Também existem aqueles tribunais que deixam a tarefa do controle para os poderes judiciários internos. O Estatuto do Tribunal Internacional para o Direito do Mar deixa expressamente para os tribunais domésticos a tarefa da execução de suas sentenças finais, contudo, no que diz respeito às medidas cautelares, o próprio Tribunal fiscaliza seu cumprimento $^{374}$. Também o Estatuto de Roma do Tribunal Penal Internacional, por sua própria natureza, depende da cooperação das cortes internas para efetivação de suas decisões, principalmente, os mandados de detenção e entrega ${ }^{375}$.

Tendo em vista as decisões anteriormente mencionadas e a análise dos instrumentos constitutivos dos principais tribunais internacionais estabelecidos nas últimas décadas, percebe-se, muito claramente, que há uma obrigação jurídica de cumprimento das decisões. Nesse rumo, o que pode ser deixado para a esfera discricionária dos Estados é apenas o meio pelo qual isso acontece. A obrigação jurídica de cumprir as decisões judiciais internacionais, por sua vez, se funda em dois pilares: a boa fé dos Estados e a consolidação do império do Direito (Rule of Law) na comunidade internacional.

A boa fé é um princípio geral do Direito que permeia todos os seus campos, exercendo sua influência, inclusive, no Direito Internacional. $\mathrm{Na}$ ordem jurídica internacional, os princípios possuem as funções lógica, axiológica, unificadora, normativa e corretiva, sendo essenciais para a estrutura e obrigatoriedade do DIP, antecedendo, inclusive a questão das fontes ${ }^{376}$. A boa-fé, portanto, atua no cerne da autocompreensão do Direito Internacional como Direito.

Quando parte de um processo judicial internacional, o Estado, uma vez sujeito à jurisdição de um tribunal internacional, submete-se às regras objetivas do exercício da

\footnotetext{
${ }^{373}$ PAUWELYN, Joost. Enforcement and Countermesures in the WTO: Rules are Rules - Toward a more collective approach. The American Journal of International Law, 2000, v. 94, $n^{\circ}$ 2. pp. 335-47. p. 337.

${ }^{374}$ GOMES ROCHA, Francisco Ozanan. The International Tribunal for the Law of the Sea. Hamburgo: Universitätspublikationen, 2001. pp 226-9, passim.

375 “Art. 86. Obrigação Geral de Cooperar: Os Estados-Partes deverão, em conformidade com o disposto no presente Estatuto, cooperar plenamente com o Tribunal no inquérito e no procedimento contra crimes da competência deste.” (ESTATUTO DE ROMA DO TRIBUNAL PENAL INTERNACIONAL).

${ }^{376}$ KOLB, Robert. La Bonne foi en Droit International Public. Contribuition à l'étude des principes généraux de droit. Paris: PUF, 2000. pp. 71-79, passim.
} 
função jurisdicional $^{377}$. A boa fé será, então, observada em duas esferas distintas: no cumprimento do tratado que constituiu e do instrumento que atribuiu a jurisdição ao órgão ${ }^{378}$ - se diferentes - e na devida diligência em relação aos atos próprios do exercício jurisdicional ${ }^{379}$. Dessa forma, pode ser extraído do princípio da boa fé a obrigação jurídica de observância e execução das decisões judiciais internacionais, pois consta nos tratados que é inerente às atividades dos tribunais.

O cumprimento de boa fé das decisões judiciais internacionais, no entanto, só possui concretude se inserido em um contexto social no qual o respeito ao Direito seja um valor norteador da sociedade. A própria jurisdicionalização do Direito Internacional é um reflexo do incremento do Rule of Law na comunidade internacional, na medida em que implementa sistemas de controle imparciais e baseados na ordem jurídica: os tribunais internacionais $^{380}$.

NOLLKAEMPER defende que o Rule of Law é um conceito a ser aplicado tanto nos planos internos como nos internacionais, devendo unir quatro elementos: o primeiro é o exercício dos poderes públicos se lastrear no Direito e ser controlado pelo Direito; o segundo consiste no fato de os poderes públicos não estabelecerem ou mudarem o Direito de acordo com sua vontade, mas sim por intermédio dos requerimentos da legalidade, observando o direito existente e não retroagindo; o terceiro se funda no fato que o Rule of Law exige que os atos dos poderes públicos sejam enquadrados nos parâmetros de respeito aos direitos fundamentais civis e políticos; e, finalmente, o quarto elemento sustenta que, quando os poderes públicos agirem em desconformidade com suas obrigações legais, eles

\footnotetext{
377 "Cependant, les règles qui gouvernent la solution juridictionelle des différends ne relèvent pas exclusivement de la volonté des parties en litige, mais sont, dans une large mesure, extérieures à celles-ci. Il en résulte que, une fois son consentement donné, l'Etat partie à un différend international ne saurait exciper de sa souveraineté pour échapper aux obligations que le droit international objectif lui impose en l'espèce, soit au titre de règle coutumière, soit au titre des principes généraux du droit. En exprimant sa volonté de recourir à une solution jurisdictionnelle pour le réglement pacifique de ses différends, l'Etat se place ipso facto sous l'empire des règles du droit objectif qui dominent le procès international, limitent sa souveraineté et lui imposent certaines obligations." (ZOLLER, Elizabeth. La Bonne Foi en Droit International Public. Paris: Pedone, 1977. p. 123).

${ }^{378}$ Id., ibid., p. 125.

${ }^{379}$ Id., ibid., p. 140.

380 "É nítida a tendência de fortalecimento dos mecanismos judiciais, como se constata pelo aumento do número de tribunais internacionais. Esta tendência é promissora, pois, caso a sociedade internacional pretenda ser uma 'comunidade de Direito', há de contar tanto com a adstrição dos Estados à norma posta quanto com um sistema de controle imparcial e independente, capaz de impedir violações da norma e interpretações inaceitáveis de seu conteúdo. Também deverá contar com a abertura deste sistema de controle aos particulares, para que não dependam exclusivamente dos Estados para fazer valer o Direito Internacional." (RAMOS, André de Carvalho. Rule of Law e a Judicialização do Direito Internacional: da mutação convencional às guerras judiciais. In: BEDIN, Gilmar Antonio. Estado de Direito, Jurisdição Universal e Terrorismo: levando o Direito Internacional a sério. Ijuí, RS: Ed. Unijuí, 2009. pp. 85-122. p. 104).
} 
devem ser responsabilizados com base no Direito pelos tribunais internacionais, órgãos administrativos e também pelos tribunais internos ${ }^{381}$.

No ano de 2005, no chamado Encontro do Milênio, a Assembleia Geral da ONU aprovou a "Declaração do Milênio" que, em seu art. $9^{\circ}$ reforça o compromisso dos seus membros em "cumprir as decisões da Corte Internacional de Justiça"382. Posteriormente, em 2006, a Assembleia aprovou a Resolução $\mathrm{n}^{\circ}$ 61, intitulada The rule of law at the national and international levels, que enfatizou o papel dos Estados em se basear em princípios de justiça, na coexistência, na cooperação com seus pares e na necessidade de reconhecimento da jurisdição da $\mathrm{CIJ}^{383}$.

Observa-se na sociedade internacional a construção de um entendimento cada vez mais forte com relação à observância e à execução das decisões dos tribunais internacionais como medidas para assegurar o Rule of Law no plano internacional. Isso eleva a questão a um patamar valorativo superior, pois passa da solução de controvérsia em si para ser parte de algo maior. CANÇADO TRINDADE comenta que vários Estados já unem vozes no sentido de valorizar o cumprimento das decisões das jurisdições internacionais como de fundamental importância, provando que "ninguém está acima do Direito" ${ }^{, 384}$.

A realização da justiça, traduzida aqui no devido cumprimento de boa fé das decisões judiciais, é o valor norteador do império do direito tanto no plano doméstico, quanto no internacional. Desse modo, os tribunais internos exercem uma função primordial no plano da efetividade das decisões judiciais internacionais. Como discutido anteriormente, os tribunais internacionais não contam com um aparelho executivo pri para fazer cumprir seus ditames. Dependem, para isso, do aparato Estatal e uma das fo pela qual isso se dá é pela via do Poder Judiciário.

\footnotetext{
381 NOLLKAEMPER, André. National Courts and the International Rule of Law. Oxford: Oxford University Press, 2012. pp. 3-6, passim.

382 UNITED NATIONS. United Nations Millenium Declaration. Resolution adpted by the General Assembly (A/55/L.2). 18 September 2000.

${ }^{383}$ UNITED NATIONS. The rule of law at the national and international levels. Resolution adopted by the General Assembly (A/61/456). 18 December 2006.

${ }^{384}$ CANÇADO TRINDADE, Antônio Augusto. Direito das Organizações Internacionais. 5. ed. rev., atual. e ampliada. Belo Horizonte: Del Rey, 2012. p. 586.
} 


\section{TRIBUNAIS INTERNACIONAIS E O PODER JUDICIÁRIO BRASILEIRO}

\subsection{PODERES JUDICIÁRIOS E O DIREITO INTERNACIONAL}

\subsubsection{Poderes Judiciários dos Estados e o Direito Internacional: breves considerações}

Na divisão política dos Estados, cada Poder possui um papel previamente estabelecido com vistas a um equilíbrio democrático. Essa divisão de funções também se aplica às questões internacionais. Por exemplo: no processo de formação de um tratado internacional, o Poder Executivo negocia e assina o texto, mas só o ratifica após a devida autorização do Poder Legislativo. O mesmo pode ser observado, na maioria dos países, nos casos de declaração de guerra ou respostas armadas a agressões. Existem, também, hipóteses em que o Executivo pode, sem prévia anuência de qualquer dos outros Poderes, tomar decisões que afetarão a esfera jurídica internacional do Estado, como aplicar uma medida de protecionismo econômico que venha a interferir nas regras do Comércio Internacional $^{385}$.

Muito embora seja o Poder Executivo titular, em primeiro lugar, pelas questões internacionais que envolvem o Estado, o Direito Internacional não obriga somente a ele, mas ao Estado como um todo ${ }^{386}$. Assim, todos os Poderes e unidades federativas são vinculados pelas normas internacionais e - com as mudanças já descritas nos capítulos anteriores - cada vez mais o DIP exige a observância de seus preceitos em todos os níveis da organização política interna, de modo que o contrário pode acarretar ato ilícito internacional $^{387}$.

$\mathrm{O}$ crescente endereçamento de normas internacionais a questões antes tidas como internas abriu espaço para uma maior atuação dos Poderes Judiciários dos Estados no plano internacional. Isso possibilitou, segundo TZANAKOPOULOS, um papel reativo dos tribunais domésticos em face da inobservância das normas internacionais. Soma-se a isso, o fato de indivíduos e outras entidades possuírem direitos atribuídos diretamente por

\footnotetext{
${ }^{385}$ Vide tópico 2, infra.

${ }^{386}$ ÉCONOMIDĖS, Constantin P. La position du Droit International dans l'ordre juridique interne et la application des règles du Droit International par le juge national. Revue Hellénique de Droit International, $49^{\text {ème }}$ Année, 1996, $\mathrm{n}^{\circ}$ 1. pp. 207-16. p. 211.

387 "Il n'y a acun doute que les Etats sont tenus d'organiser leur ordre juridique interne de manière à satisfaire à leurs obligations internationales. Il exécutent ces obligations par l'intermédiaire de leurs organes législatifs, exécutifs et judiciaires." (MOSLER, H. L'application du droit international public par les tribunaux nationaux. RCADI, 1957-I, t. 91. pp. 619-711. p. 628.
} 
obrigações internacionais, o que faz com que provoquem o Poder Judiciário sempre que acharem que esses direitos foram violados. Dessa maneira, a reação do juiz interno não será anormal, pois é sua função típica constatar se determinado ato está de acordo, ou não, com o Direito, seja ele interno ou internacional ${ }^{388}$.

Consequentemente, os tribunais domésticos passaram a ter uma função mais marcada no desenvolvimento do Direito Internacional, uma vez que possuem certa margem de discricionariedade ${ }^{389}$ para interpretar as obrigações internacionais dos Estados. Assim, estabelecem hierarquias entre obrigações convencionais, reconhecem o costume internacional, ligam obrigações de diferentes ramos do DIP, aplicando normas protetivas de uns aos outros, etc ${ }^{390}$. Nesse contexto também se desenvolveu o chamado "princípio da interpretação consistente", o qual preconiza que os Judiciários internos no exercício de suas funções devem interpretar o direito doméstico, levando em conta as obrigações internacionais do Estado ${ }^{391}$.

Percebendo essa evolução, o Instituto de Direito Internacional, no ano de 1993, na sessão de Milão, adotou a resolução intitulada $A$ atividade do juiz interno e as relações internacionais do Estado, a qual faz recomendações sobre a forma como os sistemas jurídicos nacionais devem abordar essa questão. O texto defende que sejam fornecidos meios para a devida interpretação e aplicação do Direito Internacional às jurisdições internas, bem como seja dada a garantia de independência ao Poder Executivo para decidir

\footnotetext{
388 TZANAKOPOULOS, Antionios. Domestic Courts in International Law: the International Judicial Function of National Courts. Loyola of Los Angeles International and Comparative Law Review, 2011, v. 34, n. 133. pp. 133-68. p. 141.

389 Por óbvio que essa margem de discricionariedade é permitida pelo próprio Direito Internacional, encontrando-se nos limites das normas internacionais, e não fora delas e nunca para negar-lhes vigência.

390 BENVENISTI, Eyal; DOWNS, George W. Court Cooperation, Executive Accountability, and Global Governance. New York University Journal of International Law and Politics, 2009, v. 41, n. 4. pp. 931 58. p. 940. Conforti acrescenta: "Per quanto riguarda i giudici nazionali, è chiaro anzitutto che le loro sentenze in materia di diritto Internazionale contribuiscono anch'esse all interpretazione e alla rilevazione delle norme internazionali, sia che si tratti di norme consuetudinarie sai che si tratti di norme convenzionali. In un certo senso, la loro influenza sull'evoluzione del diritto internazionale è piú 'diretta', in quanto, dal punto di vista di quest 'ultimo, essi agiscono come organi del proprio Stato, e quindi la prassi alla quale essi danno vita è prassi degli Stati." (CONFORTI, Benedetto. Qualche riflessione sul contributo dei giudici internazionali ed interni al diritto internazionale. In: VENTURINI, Gabriella ; BARIATTI, Stefania (Eds.). Diritto Individuali e Giustizia Internazionale. Liber Fausto Pocar. Milano: Giuffrè Editore, 2009. pp. 217 21. p. 219).

391 "The principle of consistent interpretation straddles international law and national law. As such it is one of the most visible manifestations of the situation of mixity that results from the interplay of international and national law. It is both induced by international legal requirement to perform international obligations, and by domestic mandate to interpret national law in the light of international law. [...]." (NOLLKAEMPER, André. National Courts and the International Rule of Law. Oxford: Oxford University Press, 2012. p. 150). "This principle of 'consistent interpretation' is to be found in the law or judicial practice of many States, and highlights how the relevant domestic courts exercise an international judicial function even when not at all engaged in the direct application of international law." (TZANAKOPOULOS, Antionios. Op. cit., 2011, p. 157).
} 
livremente sobre o tema ${ }^{392}$. Ademais, os tribunais internos devem ser devidamente habilitados por sua ordem jurídica a aplicar as normas do DIP e, para isso, devem se inspirar nos tribunais internacionais e nos seus métodos ${ }^{393}$.

Essa independência e a habilitação da ordem jurídica interna para aplicar normas internacionais são fundamentais para a afirmação de NOLLKAEMPER, para quem os tribunais nacionais são importantes asseguradores do rule of law no Direito Internacional. Isso porque o volume de casos envolvendo matérias de DIP julgados pelas cortes domésticas supera o número de casos julgados pelas internacionais ${ }^{394}$. O autor defende que os tribunais domésticos têm certas funções que promovem essa maior penetração nas questões jurídicas internacionais, ou seja: a possibilidade de resolver queixas internacionais, de controlar a legalidade de atos internos sob a luz do Direito Internacional e de desenvolver um importante papel na interpretação, determinação e desenvolvimento do DIP. NOLLKAEMPER ainda acrescenta que os Poderes Judiciários dos Estados exercem essas funções, em maior ou menor grau, dependendo de uma série de fatores que incluem: cultura jurídica e disposição de cortes e juízes nacionais de estarem abertos a observar e efetivar o Direito Internacional ${ }^{395}$.

Além disso, algumas obrigações internacionais dos Estados são endereçadas diretamente aos Poderes Judiciários. Os arts. $8^{\circ}$ (garantias judiciais) e 25 (proteção judicial) da Convenção Americana de Direitos Humanos, por exemplo, são focados na atuação dos tribunais internos com vistas à garantia do devido processo legal. Já a Convenção de Viena sobre as Relações Consulares, em seu art. 36, parágrafo $1^{\circ}$, alínea "b", impõe o dever às autoridades judiciárias de informar a repartição consular competente sempre que um nacional seu for preso.

A não observação dessas obrigações - e outras conexas ou derivadas - por parte do Poder Judiciário, pode levar à responsabilização internacional do Estado. RAMOS explica que a responsabilidade internacional por ato desse Poder pode se dar em virtude de decisão

\footnotetext{
392 "Considérant toutefois que, aux fins d'une application correcte du droit international au sein de chaque Etat selon les méthodes d'interpretation propres à ce droit, il convient de renforcer l'indépendance des jurisdictions nationales à l'égard du pouvoir exécutif et de favoriser une meilleure conanaissance du droit international par ces mêmes jurisdictions." (INSTITUT DE DROIT INTERNATIONAL. L'activité du juge interne et les relations internationales. Rapporteur: M. Benedetto Conforti. Session de Milan, 1993. p. 1). ${ }^{393}$ Id., ibid., art. $1^{\circ}$, p. 2.

394 "The volume of national case-law on such matters of international law easily outnumbers the decisions of international courts and tribunals. In any event in this respesct national case-law has a more profound effect for the actual application of international law, and the protection of the international rule of law, than do the decisions of international courts and tribunals." (NOLLKAEMPER, André. National Courts and the International Rule of Law. Oxford: Oxford University Press, 2012. p. 8).

${ }^{395}$ Id., ibid., pp. 9-10.
} 
judicial tardia ou inexistente, ou quando a decisão, no mérito, viola norma internacional ${ }^{396}$. Aliás, quando se trata de responsabilidade internacional de uma forma geral percebe-se o quanto é importante a devida atuação dos tribunais internos, pois aquela só vai poder ser implementada se forem esgotados todos os recursos internos para sanar uma violação de norma internacional ${ }^{397}$.

A partir dessas considerações pode-se ter uma dimensão da importância da atuação dos Poderes Judiciários nacionais no contexto do Direito Internacional Contemporâneo. Ademais, deve ser dada ênfase no tocante ao resguardo, em conjunto com os tribunais internacionais, do frágil Rule of Law na comunidade internacional. Por essa razão, é imprescindível que haja uma relação pautada na confiança absoluta entre essas instituições, sendo os Poderes Judiciários responsáveis por garantir a plena efetividade das decisões dos tribunais internacionais.

\subsubsection{Tribunais Internos e Tribunais Internacionais: entre harmonia e dissonância}

Nas últimas décadas, com a crescente expansão numérica dos tribunais internacionais, os Estados se submeteram à jurisdição de vários desses órgãos e, aos poucos, passaram a ter que lidar com as suas decisões vinculantes, o que provocou alguns problemas jurídicos ${ }^{398}$. Há casos em que a relação entre os tribunais domésticos e os internacionais se mostrou harmoniosa, enquanto em outros houve dissonâncias que levaram a consequências irreversíveis.

As medidas cautelares da Corte Internacional de Justiça nos Casos Breard (Paraguai v. Estados Unidos, 1998) ${ }^{399}$ e La Grand (Alemanha v. Estados Unidos, 1999) ${ }^{400}$ são claros exemplos de que a dissonância entre tribunais domésticos e internacionais pode levar a resultados graves. Em ambos os casos, nacionais do Paraguai e da Alemanha foram condenados à morte em processos que não observaram o direito de assistência consular, previsto na Convenção de Viena sobre Relações Consulares. Em razão disso, a CIJ, em

\footnotetext{
${ }^{396}$ RAMOS, André de Carvalho. Responsabilidade internacional por violação de direitos humanos: seus elementos, a reparação devida e sanções possíveis: teoria e prática do direito internacional. Rio de Janeiro: Renovar, 2004. pp. 175-6.

${ }^{397}$ Vide: CANÇADO TRINDADE, Antônio Augusto. O esgotamento dos recursos internos. 2. ed. Brasília: Ed. da UnB, 1997.

398 SHANY, Yuval. Regulating jurisdictional relations between National and International Courts. Oxford/New York: Oxford University Press, 2009. p. 2.

${ }^{399}$ INTERNATIONAL COURT OF JUSTICE. Case Concerning the Vienna Convention on Consular Relations (Paraguay v. United States of America). Request for the indication of Interim Measures of Protection. Order of 9 april 1998.

${ }^{400}$ INTERNATIONAL COURT OF JUSTICE. La Grand Case (Germany v. United States of America). Request for the indication of Interim Measures of Protection. Order of 3 march 1999.
} 
sede de medidas provisórias de proteção solicitadas pelo Paraguai e pela Alemanha, determinou que os EUA suspendessem a execução da pena de morte desses indivíduos. A Suprema Corte Americana, no entanto, não acatou a determinação e as penas foram executadas $^{401}$.

SHANY aponta como causas das dissonâncias entre tribunais internos e internacionais algumas práticas e métodos que favorecem a desintegração. Essas se baseiam na alegação da existência de diferentes normativas para cada instrumento jurídico, que acabam por condicionar a solução de uma controvérsia a vários órgãos, de acordo com sua competência material específica. O resultado são decisões válidas, porém conflitantes $^{402}$. Pode-se incluir no rol dessas práticas, a adoção do dualismo como um paradigma, bem como a equivocada incorporação às questões jurídicas, do discurso dos "regimes autocontidos", proveniente da Teoria das Relações Internacionais.

Parte da doutrina internacionalista defende que as tensões entre tribunais internos e internacionais podem trazer consequências drásticas à estrutura do Direito Internacional, pois acelerariam um potencial processo de "fragmentação" ${ }^{403}$. Uma análise mais detida da natureza da atividade jurisdicional, no entanto, já é suficiente para afastar tal hipótese, pois o que as cortes domésticas e internacionais almejam é a solução pacífica de controvérsias e a realização do Império do Direito ${ }^{404}$. Logo, trata-se de uma ameaça de natureza política que pode afetar em algum grau a eficácia do DIP, mas não sua essência.

$\mathrm{Na}$ verdade, a ideia de tribunais internos atuando para garantir a função judicial no plano internacional não é nova, mas retrata o desdobramento funcional preconizado por SCELLE, na década de 30. Segundo o autor francês, o fato de existir um Direito Constitucional da sociedade internacional e de essa carecer de instituições constitucionais

401 Vide: UNITED STATES OF AMERICA. Supreme Court. Breard v. Greene. 523 US. 371 (1998); UNITED STATES OF AMERICA. Supre Court. Federal Republic of Germany et al. v. United States et al., 526 US 111 (1999).

${ }^{402}$ SHANY, Yuval. Regulating jurisdictional relations between National and International Courts. Oxford/New York: Oxford University Press, 2009. p. 111.

403 "Finally, there is the danger that an increaseed willingness on the part of NCs to review the policies of IOs and the decisions of ITs could ultimately lead to more, rather than less, fragmentation. Instead of acting together, courts might divide themselves into rival blocs whose competition will lead to sudden reversals in regulatory policies that, in turn, will generate even greater instability and incoherence. This fear should be taken seriously." (BENVENISTI, Eyal; DOWNS, George W. Court Cooperation, Executive Accountability, and Global Governance. New York University Journal of International Law and Politics, 2009, v. 41, n. 4. pp. 931-58. p. 944).

404 "The two fundamental and inseparable aspects of international judicial function (for brevity, dispute resolution and law development) are then nothing but fundamental aspects of any judicial function (i. e. also of the domestic judicial function). Indeed, 'the essential features of the judicial settlement of disputes,' whether by domestic or by international courts, 'seem to be universally recognized', and hand-in-hand with judicial settlement goes the development of the law." (TZANAKOPOULOS, Antionios. Domestic Courts in International Law: the International Judicial Function of National Courts. Loyola of Los Angeles International and Comparative Law Review, v. 34, n. 133, 2011, pp. 133-168. p. 136). 
orgânicas, implica na realização de suas funções por intermédio dos órgãos das sociedades internas. Esses, portanto, exerceriam tanto suas competências internas quanto as internacionais, o que, por sua vez, seria a realização de um monismo institucional ${ }^{405}$. Logo, os juízes nacionais possuiriam a competência para efetivar as decisões internacionais nos seus Estados ${ }^{406}$.

Para BEDJAOUI essa relação dos tribunais domésticos com os internacionais se dá por meio de reception ou enforcement de decisões judiciais internacionais. O primeiro conceito remete às referências que os juízes nacionais fazem aos casos internacionais; já o segundo refere-se à instauração de procedimento judicial na esfera interna - seja pela parte vencedora ou por terceiros interessados - para fazer valer a decisão internacional ${ }^{407}$. Posteriormente, o autor se foca no primeiro conceito e o descreve como um procedimento de duas fases: primeiro, o juiz interno analisa se aceita a norma internacional e, depois, se adota a interpretação dada pelo órgão judicial internacional. Ademais, alerta para o fato de que o tribunal nacional não perde seu poder de apreciação nesse ínterim, podendo ou não aceitar a norma ou adotar a interpretação ${ }^{408}$.

Quando se trata de cumprimento ou execução, no entanto, a questão já não é tão simples. A natureza obrigatória das decisões judiciais internacionais não permite sua revisão ou denegação pelo juiz interno. Não faria sentido algum se a resolução de um caso por um tribunal internacional - que, na maioria das vezes só foi provocado a agir porque o Judiciário interno não solucionou a questão - fosse revista por um tribunal nacional. Do

\footnotetext{
405 "Nous nous croyons donc autorisé, après avoir constaté l'existence du Droit des gens constitutionel, à l'étudier dans ses trois fonctions essentielles et cela dans les sociétés interétatiques particulières, comme dans la communauté oecuménique du Droit des gens. Nous y verrons, en particulier, chaque organisation étatique jouer son rôle législatif, judiciaire, exécutif, comme une sorte de section ou de circonscriptions des communautés internationales particulière ou générales.[...]." (SCELLE, Georges. Précis de droit des gens. Principes et Systématique. 2eme partie. Paris: Recueil Sirey, 1934. pp. 11-2). Vide também: SCELLE, Georges. Règles générales du droit de la paix. RCADI, 1933-IV, t. 46. pp. 358-9 ; CASSESE, Antonio. Remarks on Scelle's Theory of "Role Splitting" (dedoublement fonctionnel) in International Law. European Journal of International Law, 1990, v. 1, n. 1. pp. 210-31.

406 " [...] Indeed, recent judgments issued by some national courts in countries such as the UK and Israel on the war on terror, the Iraq war, and the Palestinian uprising do seem to carry with them the promise of a more meaningful partnership between national and international courts. (...) Arguably, if national judges apply international law in a credible manner, out of an explicitly or implicitly proclaimed sense of legal obligation, then they can be viewed as parto f the international judiciary (perhaps regardless of the actual motivations which may explain their new-found internationalist tendencies). The stronger jurisdictional powers and enforcement capabilities of national courts may thus compensate for some of the shortcomings of international courts." (SHANY, Yuval. No longer a weak department of power? Reflections on the emergence of a New International Judiciary. European Journal of International Law, 2009, v. 20, n.1. pp. 73-91. pp. 85-6).

${ }^{407}$ BEDJAOUI, Mohamed. The reception by National Courts of Decisions of International Tribunals. New York University Journal of International Law and Politics, 1995-1996, v. 28. pp. 45-64. p. 47.

${ }^{408}$ Id., ibid., pp. 55-6.
} 
mesmo modo, não cabe a esse, como órgão do Estado, recusar-se a cumprir uma decisão proferida contra o mesmo ou em razão da ineficiência de seus órgãos judiciários.

A função jurisdicional internacional, como já conceituada neste estudo, pode ser vista, de maneira geral, sob dois aspectos: a resolução de controvérsias e o desenvolvimento do Direito. Nesse sentido, tribunais domésticos e tribunais internacionais possuem as mesmas funções nas sociedades em que atuam. São, pois, norteados pelos mesmos valores, o que faz com que haja uma concentricidade axiológica na sua atuação, criando um ambiente no qual a preocupação com a realização da justiça gere sinapses entre os órgãos judiciais internos e internacionais, com vistas à efetividade do Direito como um todo $^{409}$.

Essas sinapses se traduzem em mecanismos de comunicação entre os tribunais que a doutrina e as jurisprudências internacional e nacionais criaram e vêm desenvolvendo, com o intuito de promover a harmonia. Importa destacar que tais mecanismos não são fechados e impermeáveis, muito pelo contrário, devem ser aplicados em conjunto, contribuindo uns com os outros. Neste estudo serão analisados aqueles mais frequentemente abordados, como: a cortesia judicial, a subordinação, o diálogo das cortes e a cooperação jurídica internacional vertical. Os dois primeiros são baseados em extremos, enquanto os demais oferecem maior flexibilidade, conforme será demonstrado na análise a seguir.

\subsubsection{Cortesia judicial}

O princípio da cortesia judicial consiste no tratamento com "deferência e respeito" das decisões e procedimentos de um tribunal por outro. Trata-se de um mecanismo tradicional de comunicação entre cortes nacionais e estrangeiras, mas que hoje está sendo aplicado, com certa frequência, também por tribunais internacionais nas relações entre pares e com os domésticos ${ }^{410}$. A natureza jurídica desse instituto é indefinida, pendendo

\footnotetext{
409 "Existe, por isso, uma concentricidade axiológica por onde se dá a sinapse entre a atuação dos Tribunais Internacionais e Nacionais, permitindo a fluidez na transmissão de jurisdição, no sentido de que o judiciário nacional deve garantir que as decisões e procedimentos adotados no plano internacional sejam efetivados, por serem eles expressão da vontade do Estado do qual emana o dever jurisdicional interno. A concentricidade axiológica é o ambiente em que está presente a missão principal que norteia o funcionamento dos Tribunais e a atribuição a eles de poder jurisdicional, que é a efetivação da justiça, baseado em um pressuposto do que é Direito. Assim, o pressuposto da efetividade do Direito é que leva a um monismo jurisdicional por onde se comunicam as decisões judiciais." (MENEZES, Wagner. Tribunais Internacionais: jurisdição e competência. São Paulo: Saraiva, 2013. pp. 287-8).

${ }^{410}$ SHANY, Yuval. Regulating jurisdictional relations between national and international courts. Oxford/New York: Oxford University Press, 2009. p. 166.
} 
entre o costume e o princípio geral de Direito, enquanto seus efeitos legais derivam do poder inerente dos tribunais de gerenciar seus próprios procedimentos, de acordo com princípios de justiça e eficiência $^{411}$.

SLAUGHTER considera a cortesia judicial o "lubrificante das relações transjudiciais". Acrescenta, ainda, que a judicial comity exige muito mais que uma fertilização cruzada baseada na "curiosidade intelectual" dos juízes, e sim a consideração de uma verdadeira realocação das responsabilidades judiciais. Isso decorre do fato de que o funcionamento dos tribunais exige, cada vez mais, a cooperação com seus pares, sem, contudo, implicar em uma relação de subordinação ${ }^{412}$.

SHANY traça uma distinção entre os mecanismos de incorporação e a cortesia judicial, usando como exemplo as decisões da Suprema Corte de Israel sobre a construção de muros nos territórios ocupados ${ }^{413}$ e a opinião consultiva da Corte Internacional de Justiça sobre o mesmo tema ${ }^{414}$. Fica evidente que a Corte israelense aceitou os preceitos ditados pela CIJ na referida opinião, contudo, baseou-se factual e juridicamente de maneira diversa, afastando a possibilidade de um diálogo mais consistente. Isso demonstra que o mecanismo de comunicação adotado foi a cortesia, uma vez que a deferência ao decidido pelo tribunal internacional foi mínima, mas o resultado almejado foi o mesmo ${ }^{415}$.

Muito embora seja, historicamente, um importante mecanismo de comunicação entre tribunais nacionais e estrangeiros ${ }^{416}$, contemporaneamente, a cortesia judicial tem seu papel questionado, pois as relações entre órgãos judiciais estão cada vez mais institucionalizadas. Quando em vista a observância de decisões judiciais internacionais, percebe-se que há pouco espaço para a cortesia judicial, pois aquelas derivam sempre do

${ }^{411}$ SHANY, Yuval. Regulating jurisdictional relations between national and international courts. Oxford/New York: Oxford University Press, 2009. p. 172.

${ }^{412}$ SLAUGHTER, Anne-Marie. Court to Court. American Journal of International Law, 1998, v. 92, n. 4. pp. 708-12. p. 711. A autora ainda faz uma crítica à Suprema Corte Americana em razão da desconsideração da medida provisória da CIJ no Caso Breard: "The Supreme Court should have honoured this request as a matter of judicial comity, offering the ICJ the same respect that U.S. courts are increasingly according their counterparts around the world. [...]." (Id., ibid., p. 708).

${ }^{413}$ Vide: ISRAEL. Supreme Court of Israel Sitting as the High Court of Justice. Beit Sourik Villagi Council v. The Goverment of Israel. HCJ 2056/04. Judgment of 30 june 2004; ISRAEL. Supreme Court of Israel Sitting as the High Court of Justice. Mara'abe v. The Prime Minister of Israel. HCJ 7957/04. Judgment of 15 september 2005.

${ }^{414}$ INTERNATIONAL COURT OF JUSTICE. Legal consequences of the construction of a Wall in the Occupied Palestiniam Territory. Advisory Opinion of 9 july 2004.

${ }^{415}$ SHANY, Yuval. Op. cit., 2009, p. 173.

${ }^{416}$ Traços da cortesia podem ser percebidos em outros mecanismos de comunicação que serão analisados. Por exemplo, essa já foi uma das principais fontes da cooperação jurídica internacional, só que na sua vertente horizontal. Também há quem afirme sua importância no diálogo das cortes. Fica demonstrado, pois, a intercomunicação desses mecanismos e enfatizado o alerta de que não devem ser percebidos de forma estanque. 
poder jurisdicional atribuído aos tribunais internacionais, o que traduz seu cumprimento em uma obrigação e não mera cortesia.

\subsubsection{Subordinação}

Ao contrário da cortesia judicial, a subordinação dos tribunais domésticos em relação aos internacionais é o mecanismo de comunicação pelo qual é garantida a vinculação e a aplicabilidade imediata das decisões judiciais internacionais na ordem interna. Trata-se de uma relação de verticalidade ${ }^{417}$ que se instala quando os tribunais domésticos acatam os mandamentos de tribunais internacionais em sua plenitude, dando origem a uma relação completamente harmoniosa. Também se pode observar que esses órgãos judiciais internacionais atuam de forma supranacional, não necessitando observar os marcadores tradicionais, como o prévio esgotamento dos recursos internos ou o princípio da complementariedade da jurisdição internacional.

Assim, a subordinação pode ser estabelecida pelo plano internacional, seguindo preceito do próprio tribunal internacional ou do ramo do Direito Internacional que esse regula, como nos casos das decisões de reenvio prejudicial da Corte Europeia de Justiça ${ }^{418}$, nas decisões dos Tribunais Penais Internacionais ad hoc para Antiga Iugoslávia e para Ruanda $^{419}$ e nas de Pronta Libertação de Navios e Tripulações do Tribunal Internacional para o Direito do $\operatorname{Mar}^{420}$. Mas também pode ser estabelecida pelo plano interno, quando esse reconhece a superioridade do Direito Internacional sobre o ordenamento interno como no caso da Holanda ${ }^{421}$ - ou, específica e pontualmente, a submissão do Poder Judiciário Interno aos mandamentos de um determinado tribunal internacional, como no

\footnotetext{
${ }^{417}$ SLAUGHTER, Anne-Marie. A tipology of transjudicial communication. University of Richmond Law Review,1994, v. 29. pp. 99-137. p. 106.

418 Vide: LENZ, Carl Otto. The role and mechanism of the preliminary ruling procedure. Fordham International Law Journal, 1994-1995, v. 18. pp. 388-409; SHANY, Yuval. Regulating jurisdictional relations between national and international courts. Oxford/New York: Oxford University Press, 2009. pp. 33-34.

419 “[...] Também adotaram o princípio da primazia da jurisdição internacional em detrimento da jurisdição nacional, dado o momento de desconfiança contra as instituições locais (da ex-Iugoslávia e de Ruanda). Assim, ficou determinado que cada um desses tribunais teria primazia sobre as jurisdições nacionais, podendo, em qualquer fase do processo, exigir oficialmente às jurisdições nacionais que abdicassem de exercer jurisdição em favor da Corte internacional.” (RAMOS, André de Carvalho. Processo Internacional de Direitos Humanos. Análise dos sistemas de apuração de violações de direitos humanos e a implementação das decisões no Brasil. São Paulo: Saraiva, 2012. p. 274). Vide também: art. $9^{\circ}$ do Estatuto do Tribunal Penal Internacional para Ex-Iugoslávia, e art. $8^{\circ}$ do Estatuto do Tribunal Penal Internacional para Ruanda.

${ }^{420}$ CONVENÇÃO DAS NAÇÕES UNIDAS SOBRE O DIREITO DO MAR, art. 292, parágrafo $3^{\circ}$.

421 NOLLKAEMPER, André. National Courts and the International Rule of Law. Oxford: Oxford University Press, 2012. p. 73.
} 
caso da Rex v. Cooper da Suprema Corte Norueguesa ${ }^{422}$ em relação à sentença da CIJ no caso Pescarias (Reino Unido v. Noruega, 1951) ${ }^{423}$.

Embora as decisões judiciais internacionais sejam obrigatórias vinculando o Estado ao qual se direcionam, isso não significa que a relação de subordinação seja pacificamente instaurada. O modo como o Poder Judiciário de cada país vai se comunicar com os tribunais internacionais depende de uma série de fatores, dentre os quais a sua percepção e o seu nível de abertura para o Direito Internacional ${ }^{424}$. Isso, entretanto, não os escusa de cumprir o decidido. Nascem, assim, as tensões, que são fruto, na maioria das vezes, das abordagens "tudo ou nada" da relação entre os tribunais. Os mecanismos que serão analisados a seguir levam em conta essa variabilidade de fatores e possibilitam o mesmo resultado da subordinação, mas de uma forma menos conflituosa.

\subsubsection{Diálogo das cortes}

O diálogo das cortes é o mecanismo de comunicação mais discutido na atualidade. Sua principal característica é o fato de não impor uma relação de subordinação, o que acabaria aumentando o potencial conflitivo das interações, nem de cortesia, o que não levaria em conta a obrigatoriedade das decisões judiciais internacionais. Em termos bem gerais, o que se propõe aqui é um verdadeiro diálogo, no sentido de que um órgão judicial efetivamente se comunique com outro, seja utilizando o mesmo legal reasoning nas decisões, ou observando preceitos e interpretações já efetivadas por outros tribunais ao decidir casos que envolvam a aplicação de normas de sua competência.

As causas desse diálogo são variadas, mas possuem a mesma raiz: a jurisdicionalização do Direito Internacional e o consequente aumento do fluxo de decisões judiciais entre a ordem internacional e os Estados. ROMANO, ao analisar o diálogo das cortes no plano internacional, observa que os juízes de tribunais internacionais adotaram uma série de modi vivendi para evitar as tensões entre seus tribunais, o que acabou por reforçar sua autoridade mediante a efetividade de suas decisões, e por criar um ambiente

\footnotetext{
${ }^{422}$ BEDJAOUI, Mohamed. The reception by National Courts of Decisions of International Tribunals. New York University Journal of International Law and Politics, 1995-1996, v. 28. p. 58; SCHREUER, Christoph H. The Implementation of International Judicial Decisions by Domestic Courts. The International and Comparative Law Quartely, 1975, v. 24. pp. 153-83. p. 178.

${ }^{423}$ INTERNATIONAL COURT OF JUSTICE. Fisheries Case (United Kingdom v. Norway). Jugdgment of 18 december 1951.

${ }^{424}$ NOLLKAEMPER, André. Op. cit., 2012, pp. 9-10.
} 
em que possa ser concebido um sistema judicial internacional ${ }^{425}$. O mesmo raciocínio pode ser aplicado nas relações com os tribunais domésticos.

Já SLAUGHTER afirma que a causa do diálogo é o fato de que tanto juízes internacionais quanto internos têm consciência das atividades que desempenham, o que faz com que troquem experiências e, constantemente, consultem as decisões uns dos outros para resolver questões e problemas semelhantes ${ }^{426}$. Essas trocas são o combustível que a autora denomina "comunidade global de cortes", que vem crescendo conforme se desenvolve a litigância transnacional, trazendo como consequência a diminuição da cortesia judicial e o fortalecimento do diálogo 427 .

O diálogo entre tribunais internacionais e domésticos se operacionaliza na utilização cruzada das jurisprudências de um tribunal pelos outros em suas decisões ${ }^{428}$. Para evitar o risco de que esse mecanismo de comunicação se torne mera retórica, RAMOS sugere a adoção de alguns parâmetros que devem ser seguidos: i) os tribunais internos devem fazer menção a dispositivos de Direito Internacional vinculantes ao Estado do foro; ii) devem, também, mencionar casos internacionais semelhantes à lide em que o Estado do foro foi parte; iii) citar jurisprudência internacional, anterior ao objeto da lide, de órgãos que possam emitir decisões vinculantes ao Estado de foro; iv) devem dar peso aos dispositivos e à jurisprudência internacional ${ }^{429}$.

\footnotetext{
${ }^{425}$ ROMANO, Cesare. P. R. Deciphering the Grammar of the International Jurisprudential Dialogue. New York University International Law and Politics Journal, 2009, v. 41. pp. 755-87. pp. 756-7.

426 "The result is that participating judges see each other not only as servants and representatives of a particular polity, but also as fellow professionals in an endeavor that transcends national borders. They face common substantive and institutional problems, they learn from one another's experience and reasoning; and they cooperate directly to resolve specific disputes. Increasingly, they conceive of themselves as capable of independent action in both international and domestic realms. Over time, whether they sit on a national supreme or constitutional court or an international court or tribunal, they are increasingly coming to recognize each other as participants in a common judicial enterprise." (SLAUGHTER, Anne-Marie. A global community of courts. Harvard International Law Journal, 2003, v. 44. pp. 191-219. p. 193).

${ }_{427}$ Id., ibid., p. 194.

428 "De façon générale, l'interaction des jurisprudences, qu'il s'agisse des jurisprudences internationales entre elles ou de celles-ci et des jurisprudences nationales, prend la forme d'emprunts à la démarche juridique suivie par le juge international, jamais celle de la transposition de la solution finale donnée par une jurisdiction dans le dispositif de sa décision. Au demeurant, dans les relations qu'entretiennent les jurisprudences relevant du même ordre juridique ou d'ordres juridiques différents, ce n'est pas tant la décision finale de l'arrêt qui importe que le raisonnement juridique (données factuelles rassemblées et mise en cohérence et règles de droit invoquéés) pour y pavenir." (KAMTO, Maurice. Les Interactions des Jurisprudences Internationales et des Jurisprudences Nationales. In: SOCIETÉ FRANÇAISE POUR LE DROIT INTERNATIONAL. La Jurisdictionnalisation du Droit International. Colloque de Lille. Paris : Pedone, 2003. pp. 393-460. p. 431).

${ }^{429}$ RAMOS, André de Carvalho. Pluralidade das ordens jurídicas: a relação do direito brasileiro com o direito internacional. Curitiba: Juruá, 2012. pp. 78-9.
} 
A título de ilustração da forma como ocorre o diálogo entre tribunais internos e internacionais, pode-se citar, dentre outras $\operatorname{tantas}^{430}$, as decisões das cortes constitucionais Argentina $^{431}$ e Peruana ${ }^{432}$ sobre a vinculação da jurisprudência da Corte Interamericana de Direitos Humanos na interpretação de dispositivos do Pacto de San José, e do Tribunal Constitucional Alemão no famoso caso Görgülü em relação a uma decisão da Corte Europeia de Direitos Humanos, o que acabou por estabelecer o modo como o diálogo entre esses órgãos se daria dali em diante ${ }^{433}$.

Nota-se que o diálogo das cortes tem uma função essencialmente preventiva, pois, ao levar em conta a jurisprudência de um tribunal internacional, o tribunal interno se resguarda do risco de vir a cometer um ato ilícito internacional por desrespeitar uma obrigação internacional, mesmo que entenda o contrário. Trata-se de um braço do princípio da interpretação consistente, segundo o qual os direitos internos devem ser interpretados em consonância com as obrigações internacionais do Estado.

Embora se constitua num mecanismo de conciliação por excelência, só o diálogo das cortes não é suficiente para garantir o pleno cumprimento das decisões internacionais, pois, muitas delas podem demandar obrigações de fazer e não fazer do Poder Judiciário dos Estados, o que implicaria em uma ação direta e não em mera citação cruzada de jurisprudências. Para sanar essa deficiência, o ideal é a combinação do diálogo com o mecanismo da cooperação jurídica internacional vertical, que prevê meios para operacionalização do decidido.

\footnotetext{
${ }^{430}$ Vide: KAMTO, Maurice. Les Interactions des Jurisprudences Internationales et des Jurisprudences Nationales. In: SOCIETÉ FRANÇAISE POUR LE DROIT INTERNATIONAL. La Jurisdictionnalisation du Droit International. Colloque de Lille. Paris: Pedone, 2003. pp. 393-460. pp. 441-50.

${ }^{431}$ REPÚbliCA ARGENTINA. Corte Suprema de Justicia de la Nación. Recurso de Hecho S. 1767 XXXVIII. 14 de junio de 2005.

${ }_{432}$ REPÚBLICA DO PERU. Tribunal Constitucional. Colegio de Abogados del Callao (demandante) c. Congreso de la República (demandado). Resolución del 19 junio de 2007.

433 "Segundo o Tribunal Constitucional alemão, as decisões da Corte Europeia de Direitos Humanos não vinculam os tribunais alemães. Isso, no entanto, não faz com que seja possível imaginar que a questão se resume - ao contrário do que afirmei acima - a uma questão binária (ou existe ou não existe vinculação). $\mathrm{O}$ problema é mais complexo. Segundo o Tribunal Constitucional alemão, embora não haja vinculação de forma estrita, desconsiderar as decisões da Corte Europeia de Direitos Humanos não seria compatível com a proteção dos direitos humanos e com o princípio do Estado de Direito. Nesse sentido, não levar em consideração decisões da Corte Europeia seria tão equivocado quanto tentar aplicá-las diretamente, como se houvesse uma supremacia pura e simples das decisões dessa corte em face das decisões dos tribunais nacionais." (SILVA, Virgílio Afonso da. Integração e diálogo constitucional na América do Sul. In: BOGDANDY, Armin von; PIOVESAN, Flávia; ANTONIAZZI, Mariela Morales (Orgs.). Direitos humanos, democracia e integração jurídica na América do Sul. Rio de Janeiro: Lúmen Juris, 2010. pp. 515-30. p. 521).
} 


\subsubsection{Cooperação Jurídica Internacional Vertical}

A cooperação jurídica internacional é, nos dias atuais, um importante mecanismo de efetivação do Direito, possibilitando-lhe a concretização de sua vocação transnacional ao permitir o fluxo de atos jurisdicionais pelas fronteiras estatais. Na vertente horizontal, ou seja, nas relações entre Estados, a cooperação jurídica internacional pode ser conceituada como "um conjunto de medidas e mecanismos pelos quais órgãos competentes dos Estados solicitam e prestam auxílio recíproco para realizar, em seu território, atos préprocessuais ou processuais que interessem à jurisdição estrangeira"434.

Recentemente, com a multiplicação dos tribunais internacionais, uma nova modalidade de cooperação jurídica internacional tem se desenvolvido - a cooperação jurídica internacional vertical. Essa, por sua vez, pode ser definida como um conjunto de atos processuais praticados por autoridades judiciárias ou administrativas do Estado de foro com o objetivo de "assegurar a efetividade de ação que se desenvolve perante tribunal internacional, ao qual se vincula este Estado, direta ou indiretamente, atribuindo eficácia às decisões interlocutórias ou definitivas deste tribunal"435.

O modo como o Estado vai efetivar a cooperação depende essencialmente do paradigma que adotará nas relações com os tribunais internacionais. ABADE aponta a existência de três paradigmas informadores dos valores essenciais da cooperação jurídica internacional ${ }^{436}$ : o do soberanismo ou coexistência desigual, o da cooperação interessada, e o da confiança e reconhecimento mútuo. O primeiro visa impedir que a efetivação das decisões internacionais viole a soberania do Estado e suas opções de política judicial, o que gera um ambiente de desconfiança e hegemonia do sistema jurídico interno. O segundo busca pautar a cooperação com base em tratados que, dentre outras inovações, designam órgãos internos (autoridades centrais) para operacionalizar os pleitos, e clarificar os motivos para uma eventual denegação. Embora seja uma evolução em relação ao primeiro paradigma, a autora alerta para o fato de que aqui a cooperação ainda é mantida sob o signo do interesse nacional, o que possibilita a denegação total ou parcial dos pedidos. Por fim, o terceiro paradigma figura como o ideal, no qual há o reconhecimento das decisões

\footnotetext{
${ }^{434}$ ABADE, Denise Neves. Direitos fundamentais na cooperação jurídica internacional: extradição, assistência jurídica, execução de sentença estrangeira e transferência de presos. São Paulo: Saraiva, 2013. p. 27.

${ }^{435}$ VERGUEIRO, Luiz Fabrício Thaumaturgo. Implementação da Cooperação Jurídica Internacional Vertical. Tese de doutorado. Universidade de São Paulo. São Paulo, 2012. p. 84.

${ }^{436}$ Esses três paradigmas foram propostos pela autora com vistas à cooperação jurídica internacional entre Estados em matéria penal, contudo, encaixam-se também na cooperação vertical.
} 
sem maiores questionamentos das autoridades nacionais, em um ambiente que impera a confiança $^{437}$.

Um importante elemento da cooperação jurídica internacional vertical é a figura das enabling legislations, que são leis de direito interno que estabelecem o modo como a relação com os tribunais internacionais se dará, operacionalizando, assim, a cooperação. O problema é que esses diplomas legais, muitas vezes, não observam os preceitos dos tribunais aos quais pretendem se direcionar e acabam causando mais dissonância que harmonia nas relações entre os órgãos judiciais nacionais e internacionais ${ }^{438}$.

Como já destacado, a cooperação jurídica internacional vertical possibilita a instrumentalização das decisões judiciais internacionais, pois empresta aos tribunais internacionais os braços que o sistema internacional não possui ${ }^{439}$. O Tribunal Penal Internacional, por exemplo, quando emite um pedido cooperacional para os Estados-parte do Estatuto de Roma, espera uma ação concreta, como a tomada de um depoimento ou a prisão e entrega de um investigado ${ }^{440}$. A Corte Interamericana de Direitos Humanos, ao estabelecer medidas provisórias ou obrigações de fazer e não fazer nas sentenças finais, também intenciona que medidas concretas sejam utilizadas pelo Estado para que seus mandamentos sejam efetivos, como a soltura de alguém preso ou a revogação de uma lei que fere a $\mathrm{CADH}^{441}$. Assim, quando a efetivação dessas decisões precisar de uma atuação

\footnotetext{
${ }^{437} \mathrm{AB} A D E$, Denise Neves. Direitos fundamentais na cooperação jurídica internacional: extradição, assistência jurídica, execução de sentença estrangeira e transferência de presos. São Paulo: Saraiva, 2013. pp. 58-69, passim.

438 "Ocorre que essas normas, típicas dos Estados que adotam a concepção dualista de Direito - embora vários dos países que as adotaram especificamente para viabilizar a cooperação jurídica vertical não o sejam - trazem consigo o inconveniente teórico prático de efetuarem uma adaptação unilateral dos textos convencionais, podendo, com isto, estabelecer limites e obstáculos não previstos nos Tratados e Convenções Internacionais, que se pretendem aplicáveis de maneira uniforme em relação a todos os signatários." (Id., ibid., p. 85). Vide, também, a crítica de Schreuer sobre a necessidade de mecanismos legais para incorporação de decisões judiciais internacionais: "The requirement of a State having to indicate its willingness to bring it municipal law into line with its international obligations by appropriate internal procedures was thus occasionaly used to shift responsability for delicate international questions to the executive or legislative. Under this doctrine a domestic court confronted with a claim based on international adjudication will be compelled to ignore it." (SCHREUER, Christoph H.. The Implementation of International Judicial Decisions by Domestic Courts. The International and comparative Law Quartely, 1975, v. 24, pp. 153-83).

439 "Despite a relatively high degree of compliance with judgments of the International Court and of other international judicial bodies, their lack of power to secure compliance with these decisions remains one of the weakest points in international judicial settlement. An effective system of international adjudication will therefore ultimately dependo $n$ the degree of co-operation shown by organs with a more immediate control over assets of the parties." (SCHREUER, Christoph H. Op. cit., 1975, p. 159).

${ }^{440}$ Vide análise crítica: KNOOPS, Geert-Jan Alexander; AMSTERDAN, Robert R. The Duality of State Cooperation Within International and National Criminal Cases. Fordham International Law Journal, 2006-2007, v. 30. pp. 260-95.

${ }^{441}$ Vide: RAMOS, André de Carvalho. Processo Internacional de Direitos Humanos. Análise dos sistemas de apuração de violações de direitos humanos e a implementação das decisões no Brasil. São Paulo: Saraiva, 2012. pp. 383-93.
} 
direta do Poder Judiciário dos Estados, o que se espera é que esse o faça pelo paradigma da confiança e reconhecimento mútuo.

O mecanismo de comunicação da cooperação jurídica é, em alguns casos, confundido com o da subordinação. De fato, ao operacionalizar uma decisão judicial internacional em seu território sem questioná-la ou submetê-la a qualquer juízo de revisão, o tribunal interno está cooperando com o internacional ao mesmo tempo em que se subordina a sua decisão. Isso, contudo, pode não acontecer quando a cooperação é interessada ou norteada pelo soberanismo. Também possui traços da cortesia judicial, pois essa ainda figura como fonte da cooperação na vertente horizontal. Ademais, percebe-se o diálogo das cortes no sentido que, ao cumprir uma decisão, o juiz nacional reconhece a validade da jurisprudência internacional. Logo, o presente mecanismo figura como o mais completo, pois congrega todos os outros com o objetivo final de fazer valer as decisões dos tribunais internacionais.

\subsection{TRIBUNAIS INTERNACIONAIS E O PODER JUDICIÁRIO BRASILEIRO}

\subsubsection{Ordem Jurídica Brasileira e o Direito Internacional: análise sob a luz da Constituição Federal de 1988}

Consideradas as cartas políticas fundamentais dos Estados, as constituições consistem em um sistema de normas jurídicas, escritas ou costumeiras, que organizam seus elementos constitutivos ${ }^{442}$. O conteúdo dos textos constitucionais foi sendo modificado no curso da História, contudo, um fenômeno próprio da contemporaneidade foi o crescimento do tratamento de questões relativas às relações exteriores no corpo das Cartas Magnas ${ }^{443}$.

De acordo com DALLARI, se no chamado "constitucionalismo clássico" as constituições tratavam apenas da repartição das competências entres os poderes no que tange à política externa, já “a constitucionalização de princípios de relações exteriores tem

\footnotetext{
442 "A constituição do Estado, considerada sua lei fundamental, seria, então, a organização dos seus elementos essenciais: um sistema de normas jurídicas, escritas ou costumeiras, que regula a forma do Estado, a forma de seu governo, o modo de aquisição e exercício do poder, o estabelecimento de seus órgãos, os limites de sua ação, os direitos fundamentais do homem e as respectivas garantias. Em síntese, a constituição é o conjunto de normas que organiza os elementos constitutivos do Estado." (SILVA, José Afonso da. Curso de Direito Constitucional Positivo. 27. ed. rev. e atualizada (até a Emenda Constitucional n. 52.). São Paulo: Malheiros, 2006. pp. 37-8, grifos do autor).

443 "[...] Jadis conçue comme la règle technique réglant le mode de fonctionément des organes du pouvoir étatique, la Constituition vise aujourd'hui à être un instrument de moralisation du pouvoir qui décrit un idéal de vie communautaire et proclame les pricnipes fondamentaux de l'ethique nationale et internationale. [...]. " (VISSCHER, Paul De. Les tendances internationales des constitutions modernes. RCADI, 1952-I, t. 80. pp. 511-78. p. 516).
} 
sido uma marca dos textos mais recentes" ${ }^{444}$. Essa constante expansão do tratamento constitucional das relações exteriores deu origem a um campo de estudo denominado "Direito Constitucional Internacional".

MIRKINE-GUETZÉVITCH, em curso na Academia de Direito Internacional de Haia, em 1933, definiu como Direito Constitucional Internacional, aquelas normas de direito interno e de direito constitucional nacional que possuem uma eficácia ou significado internacional ${ }^{445}$. Mais atualmente, MELLO, em obra na qual se dedica exclusivamente a essa questão, oferece um conceito mais restrito. Segundo o autor, o Direito Constitucional Internacional consiste em normas constitucionais que regulamentam as relações exteriores dos Estados, variando de um para o outro, e no mesmo Estado, de acordo com o período histórico, podendo ser mais ou menos abrangente nos textos constitucionais ao longo da história de um país ${ }^{446}$.

No Brasil, desde a Carta Monárquica de 1824, as constituições buscam estabelecer certas normas as quais o Estado brasileiro deve observar na condução de sua política externa $^{447}$. As diversas constituições que se sucederam, em geral, endereçavam questões mais técnicas e objetivas, como a divisão de competência entre os poderes do Estado em matéria de relações internacionais, e reafirmavam a vocação pacífica, os interesses de soberania e os comerciais $^{448}$. Foi na Constituição Federal de 1988, entretanto, que o tema foi mais amplamente abordado.

\footnotetext{
${ }^{444}$ DALLARI, Pedro B.A. Constituição e relações exteriores. Prefácio de Celso Lafer. São Paulo: Saraiva, 1994. p. 16.

445 "Le Droit Constitutionelle international est pour nous, toujours le droit interne, le droit constitutionel national, dont les dispositions on une efficacité internationale, une signification internationale." (MIRKINEGUETZÉVITCH, Boris. Le Droit Constitutionnel et l'organisation de la paix. RCADI, 1933-III, t. 45. pp. 667-773. p. 674).

446 "Formuladas essas ressalvas podemos definir o D. Constitucional Internacional como as normas constitucionais que regulamentam as relações exteriores do estado. Estas normas variam de uma constituição para outra, isto é, entre os estados, bem como dentro do próprio estado cada constituição de acordo com o momento histórico inclui ou elimina determinadas normas. A Constituição de 1988 fez uma enumeração dos princípios no art. $4^{\circ}$ mais extensa do que as anteriores, já a Constituição de 1946 continha norma sobre expulsão de estrangeiro que foi eliminada nas constituições posteriores. [...]." (MELLO, Celso D. de Albuquerque. Direito Constitucional Internacional: uma introdução. Constituição de 1988 revista em 1994. Rio de Janeiro: Renovar, 1994. p. 4).

${ }^{447}$ DALLARI, Pedro. Constituição e relações exteriores. Prefácio de Celso Lafer. São Paulo: Saraiva, 1994. p. 23.

${ }^{448}$ Vide também: VALLADÃO, Haroldo. O Direito Internacional no Projeto da Constituição. Boletim da Sociedade Brasileira de Direito Internacional. Jan./Jun. 1946, ano II, $\mathrm{n}^{\circ}$ 3. pp. 7-17; NASCIMENTO E SILVA, G.E. Direito Internacional no Projeto de Reforma da Constituição. Boletim da Sociedade Brasileira de Direito Internacional. Jan./Dez. 1996, ano XXII, $\mathrm{n}^{\circ} 43$ e 44. pp. 5-21; PANNUNZIO, Eduardo. A judicialização das relações internacionais no Brasil em face do princípio constitucional da prevalência dos direitos humanos. Tese de doutorado. Faculdade de Direito da Universidade de São Paulo, 2012. pp. 4164; DALLARI, Pedro. Op. cit., 1994, pp. 23-55.
} 
A CF de 1988 foi elaborada no contexto do chamado constitucionalismo global ${ }^{449}$ - que não deixa de ser um reflexo "interno" da expansão própria do Direito Internacional Contemporâneo - que marca a abertura dos textos constitucionais à normativa da comunidade internacional. Essa abertura, segundo CANOTILHO, é um verdadeiro princípio, denominado por ele de "princípio da abertura internacional", que se fundamenta em uma série de fatores que vão desde a autocompreensão do Estado como internacionalmente limitado até a dimensão antropológica de amizade entre os povos e indivíduos. Por fim, o constitucionalista português conclui que "a ordem internacional e a ordem interna são ordens de paz e de solução pacífica de conflitos" ${ }^{\text {"450 }}$.

RAMOS afirma que "há uma crise de paradigma no Direito Interno, em especial no Direito Constitucional", causada pelo chamado neoconstitucionalismo. Segundo o autor, esse novo modelo vincula a interpretação das normas constitucionais a princípios, defende a constitucionalização de todo o ordenamento jurídico, indica o ativismo judicial como meio para se fazer valer os valores constantes na Carta Magna e "aceita a abertura da Constituição às normas internacionais, para fazer frente aos desafios sociais, econômicos, ambientais e políticos pelos quais passa o Estado" 451 .

Nesse contexto, a Constituição Cidadã trouxe uma série de dispositivos demonstrativos dessa abertura que, somados aos já tradicionais reguladores de competências em matéria de relações exteriores, formam - de acordo com o conceito de Mello exposto supra - o rol do Direito Constitucional Internacional vigente no Brasil. Essas normas, contudo, são frequentemente mal compreendidas e interpretadas em razão da tradição jurídica soberanista brasileira e do fato de que o Direito Internacional ainda é

\footnotetext{
449 "Estes parâmetros teóricos influenciam hoje claramente as imbricações do direito constitucional com o direito internacional. Com efeito, as relações internacionais devem ser cada vez mais relações reguladas em termos de direito e de justiça, convertendo-se o direito internacional numa verdadeira ordem imperativa, à qual não falta um núcleo material duro - o jus cogens internacional - vertebrador quer da 'política e relações internacionais', quer da própria construção constitucional interna. Para além deste jus cogens, o direito internacional tende a transformar-se em suporte das relações internacionais através da progressiva elevação dos direitos humanos - na parte em que não integrem já o jus cogens - a padrão jurídico de conduta política, interna e externa. Esta últimas premissas - o jus cogense os direitos humanos -, articuladas com o papel da organização internacional, fornecerão um enquadramento razoável para o constitucionalismo global." (CANOTILHO, J.J. Gomes. Direito Constitucional e Teoria da Constituição. 7. ed. 9. reimpr. Coimbra: Almedina, 2003. p. 1370).

${ }^{450}$ CANOTILHO, J.J. Gomes. Op. cit., 2003, pp. 369-70, passim.

${ }^{451}$ RAMOS, André de Carvalho. A pluralidade de ordens jurídicas e a nova centralidade do Direito Internacional. Boletim da Sociedade Brasileira de Direito Internacional, ano XCVIII, ago./dez. 2013, v. 1, n, 119-124. pp. 19-45. p. 29.
} 
deficientemente ministrado na maioria das faculdades de Direito do país ${ }^{452}$, fatores esses que geram conflitos ${ }^{453}$.

O primeiro reflexo dessa abertura ao Direito Internacional na Constituição de 1988 ocorre, certamente, em seu art. $4^{\circ 454}$, no qual foram enumerados princípios que se assemelham - quando não idênticos na redação - aos característicos do Direito Internacional Contemporâneo - como o da prevalência dos direitos humanos (inciso II) e o da cooperação entre povos para o progresso da humanidade (inciso IX), por exemplo - a orientar a República Federativa do Brasil em suas relações exteriores ${ }^{455}$.

MELLO critica a adoção pelo constituinte originário das expressões “fundamentos", "princípios fundamentais" e, tão somente, "princípios” no texto do Título I da Carta Magna. De acordo com o autor, a palavra "fundamento" possui um viés técnico que remete às fontes da obrigatoriedade do Direito, logo, são princípios básicos que devem ser levados em conta. Nesse sentido, "princípios" e "fundamentos" teriam o mesmo sentido $^{456}$. Acrescenta o autor que a expressão "princípios" adotada no art. $4^{\circ}$ significa "normas e preceitos que o Brasil adotará na sua política externa" ${ }^{457}$. Por fim, MELLO defende a obrigatoriedade da sua observância, argumentando que as bases do Estado brasileiro não podem ser meras normas de eficácia limitada ${ }^{458}$.

452 "O estudo do Direito, no globalizado e conturbado mundo pós-moderno, não pode prescindir da boa formação em Direito Internacional: parecem ter se dado conta disso os profissionais do Direito, das relações internacionais e da diplomacia. Essa necessidade se faz sentir junto ao mercado e pelo mercado, com a mudança considerável da percepção da necessidade e do papel das disciplinas do Direito Internacional." (NASCIMENTO E SILVA, G. E.; CASELLA, Paulo Borba; BITTENCOURT NETO, Olavo de Oliveira. Direito Internacional Diplomático: Convenção de Viena sobre Relações Diplomáticas na teoria e na prática. 4. ed. rev., atual. e ampl. São Paulo: Saraiva, 2012. p. 89).

${ }^{453}$ Alerta Ramos: "Resta saber se essa abertura constitucionalista ao direito internacional sobreviverá ao reconhecimento de dissonâncias, em especial quando determinada decisão nacional de interpretação de um tratado (v.g., do nosso Supremo Tribunal Federal) for considerada violação deste, por um órgão internacional." (RAMOS, André de Carvalho. Pluralidade das ordens jurídicas: a relação do direito brasileiro com o direito internacional. Curitiba: Juruá, 2012. p. 23).

454 “Art. $4^{\circ}$. A República Federativa do Brasil rege-se nas suas relações internacionais pelos seguintes princípios: I - independência nacional; II - prevalência dos direitos humanos; III - autodeterminação dos povos; IV - não-intervenção; V - igualdade entre os Estados; VI - defesa da paz; VII - solução pacífica dos conflitos; VIII - repúdio ao terrorismo e ao racismo; IX - cooperação entre os povos para o progresso da humanidade; X - concessão de asilo político. Parágrafo único. A República Federativa do Brasil buscará a integração econômica, política, social e cultural dos povos da América Latina, visando à formação de uma comunidade latino-americana de nações." (BRASIL. Constituição da República Federativa do Brasil de 1988. 25. ed. São Paulo: Revista dos Tribunais, 2005).

${ }^{455}$ Nas palavras de Celso Lafer, o art. 4 "é representativo da abertura ao mundo, inerente a um regime democrático." (LAFER, Celso. A internacionalização dos direitos humanos: constituição, racismo e relações internacionais. Barueri, SP: Manole, 2005. p. 13).

${ }^{456}$ MELLO, Celso D. de Albuquerque. Direito Constitucional Internacional: uma introdução. Constituição de 1988, revista em 1994. Rio de Janeiro: Renovar, 1994. p. 114.

${ }^{457}$ Id., ibid., p. 115.

${ }^{458}$ Id., ibid., p. 116. 
DALLARI expressa um entendimento similar ao constatar que a fixação desses princípios nas constituições contemporâneas auxilia no estabelecimento de limites e na formulação de estímulos em matéria de política externa. Logo, ao estabelecê-los, há a fixação de uma "primazia de valores que não deixam de permear não só a retórica, mas a própria materialização dos atos decorrentes da política externa" ${ }^{~} 59$. Da mesma forma, afirma que a constitucionalização de princípios de relações exteriores possibilita "o controle político da ação externa do Estado pelo Poder Legislativo e o controle jurídico pelo Poder judiciário" 460 .

Dessa maneira, pode-se concluir que, ao estabelecer princípios pelos quais o Brasil deverá se guiar nas relações exteriores, a Constituição Federal de 1988 (CF/88) oferece um guia a ser seguido na formulação da política externa e na interpretação das normas de direito interno relativas às relações internacionais do Estado brasileiro. Assim, esse dispositivo possui eficácia imediata ${ }^{461}$ no que tange à prática e formulação da política externa, e eficácia interpretativa ${ }^{462}$, no que se refere à aplicação de outras normas endereçadas ao tema.

É certo, contudo, que o art. $4^{\circ}$ traz em seu corpo princípios que se mostraram, na prática do DIP, potencialmente conflitivos, como o da autodeterminação dos povos (inciso III) e o da não intervenção (inciso IV), e, mais sensivelmente, esse último com o da prevalência dos direitos humanos (inciso II). Os casos de conflito devem ser analisados em concreto, observando-se, em primeiro lugar, a normativa internacional, geral ou concreta, sobre o tema e, depois, aplicar a ponderação e a razoabilidade para a determinação de qual princípio deve prevalecer. Isso se deve ao fato de que o conteúdo desses preceitos é determinado pela comunidade internacional ${ }^{463}$, não cabendo, portanto, ao intérprete interno fazê-lo, caso haja uma interpretação internacionalista anterior sobre a questão ${ }^{464}$.

\footnotetext{
${ }^{459}$ DALLARI, Pedro. Constituição e relações exteriores. Prefácio de Celso Lafer. São Paulo: Saraiva, 1994. p. 18.

${ }^{460}$ Id., ibid., p. 16.

461 "Pela eficácia direta, já referida, também, como positiva ou simétrica, o princípio incide sobre a realidade à semelhança de uma regra, pelo enquadramento do fato relevante na proposição jurídica nele contida. [...] Portanto, e em primeiro lugar, um princípio opera no sentido de reger a situação da vida sobre a qual incide, servindo como fundamento para a tutela do bem jurídico abrigado em seu relato." (BARROSO, Luis Roberto. Curso de Direito Constitucional Contemporâneo: os conceitos fundamentais e a construção do novo modelo. 4. ed. São Paulo: Saraiva, 2013. pp. 345-6).

462 "A eficácia interpretativa consiste em que o sentido e alcance das normas jurídicas em geral devem ser fixados tendo em conta os valores e fins abrigados nos princípios constitucionais. Funcionam eles, assim, como vetores da atividade do intérprete, sobretudo na aplicação de normas jurídicas que comportam mais de uma possibilidade interpretativa." (Id., ibid., p. 346).

463 "O art. $4^{\circ}$ da Constituição de 1988 é indicativo desta abertura, pois os princípios nele positivados estão próximos dos que basicamente regem, de acordo com o Direito Internacional Público, ex vi do art. $2^{\circ}$ da Carta da ONU, a comunidade internacional. São muito semelhantes aos codificados na época da coexistência
} 
Analisados os princípios, passa-se ao estudo da divisão constitucional de competências em matéria de relações exteriores. A CF/88, assim como já faziam as constituições anteriores, dividiu as competências para operacionalização da política externa entre os Poderes institucionais do Estado brasileiro, fixando ao Executivo, Legislativo e Judiciário diferentes papéis, desde a elaboração até a fiscalização desses atos. Essa divisão espelha o balanço democrático entre os Poderes e as funções do Estado, sujeitando a política externa a um controle de "freios e contrapesos" 465 .

O Poder Executivo possui, historicamente, o protagonismo na condução da política externa dos Estados. Assim, a CF/88 delega à União a competência de "manter relações com Estados estrangeiros e participar de organizações internacionais" 466 e, privativamente, ao Presidente da República, a de "manter relações com Estados estrangeiros e acreditar em seus representantes diplomáticos" ${ }^{467}$. A maioria das competências delegadas a esse Poder, entretanto, depende da aprovação ou referendo do Congresso Nacional, como: celebrar tratados e atos internacionais ${ }^{468}$, declarar a guerra e celebrar a paz ${ }^{469}$, nomear

pacífica da Guerra-Fria, na Declaração Relativa aos Princípios do Direito Internacional referentes às relações de amizade e cooperação entre os Estados, aprovada pela Assembleia Geral em 24 de outubro de 1970, na celebração dos 25 anos da Carta da ONU. [...]." (LAFER, Celso. A internacionalização dos Direitos Humanos: constituição, racismo e relações internacionais. Barueri, SP: Manole, 2005. p. 14).

${ }^{464}$ Sobre o assunto, Pannunzio defende que: "Em realidade é interessante notar que a maioria, se não todos os postulados do art. $4^{\circ}$ correspondem a princípios constituídos no âmbito do Direito Internacional. Dessa forma, a norma constitucional é um exemplo claro da interação entre as ordens jurídicas interna e internacional, na qual o direito internacional influencia o desenvolvimento do direito constitucional que, por sua vez, passa a orientar a atuação internacional do Estado e, assim, retroalimenta a própria formulação do direito internacional cuja criação ainda se dá, essencialmente, a partir dos Estados." (PANNUNZIO, Eduardo. A judicialização das relações internacionais no Brasil em face do princípio constitucional da prevalência dos direitos humanos. Tese de doutorado. Faculdade de Direito da Universidade de São Paulo, 2012. pp. 68-9).

465 “O sistema de separação dos poderes, consagrado nas Constituições de quase todo o mundo, foi associado à ideia de Estado Democrático e deu origem a uma engenhosa construção doutrinária, conhecida como sistema de freios e contrapesos. Segundo essa teoria os atos que o Estado pratica podem ser de duas espécies: ou são atos gerais ou são especiais. Os atos gerais, que só podem ser praticados pelo poder legislativo, consistem na emissão de regras gerais e abstratas, não se sabendo, no momento de serem emitidas, a quem elas irão atingir. Dessa forma, o poder legislativo, que só pratica atos gerais, não atua concretamente na vida social, não tendo meios para cometer abusos de poder nem para beneficiar ou prejudicar uma pessoa ou um grupo em particular. Só depois de emitida a norma geral é que se abre a possibilidade de atuação do poder executivo por meio de atos especiais. O executivo dispõe de meios concretos para agir, mas está igualmente impossibilitado de atuar discricionariamente, porque todos os seus atos estão limitados pelos atos gerais praticados pelo legislativo. E se houver exorbitância de qualquer dos poderes surge a ação fiscalizadora do poder judiciário, obrigando cada um a permanecer nos limites de sua respectiva esfera de competências." (DALlARI, Dalmo de Abreu. Elementos de teoria geral do Estado. 30. ed. São Paulo: Saraiva, 2011. p. 218).

${ }^{466}$ BRASIL. Constituição da República Federativa do Brasil de 1988. 25. ed. São Paulo: Revista dos Tribunais, 2005, art. 21, inciso I.

${ }^{467}$ Id., ibid., art. 84, inciso VII.

${ }^{468}$ Id., ibid., art. 84, inciso VIII, combinado com o art. 49, inciso I.

${ }^{469}$ Id., ibid., art. 21, inciso II, combinado com os arts. 84, incisos XIX e XX, e 49, inciso II. 
representantes diplomáticos ${ }^{470}$, conduzir e regular o comércio exterior ${ }^{471}$, legislar sobre questões relativas à nacionalidade, nacionalização, saída compulsória de estrangeiros e imigração $^{472}$, etc. Do mesmo modo, cabe ao Poder Legislativo, com a sanção do Presidente da República, a delimitação do território nacional ${ }^{473}$. Logo, vislumbra-se no texto constitucional um perfeito equilíbrio entre esses dois Poderes da República, também nas questões relativas à política externa.

Ao Poder Judiciário, a Constituição Federal de 1988, além de delegar um rol de competências, abriu a possibilidade, com o estabelecimento dos princípios do art. $4^{\circ}$, de um controle jurisdicional dos atos de política externa ${ }^{474}$. É nessa esfera de competências, portanto, que há uma maior potencialidade de conflitos jurídicos, tanto entre normas de Direito Internacional e de direito interno, quanto entre os Poderes do próprio Estado brasileiro, o que requer uma análise mais cautelosa.

\subsubsection{Competências do Poder Judiciário em matéria de Direito Internacional}

A Constituição Federal de 1988 traz as competências do Poder Judiciário de maneira fragmentada, referido-se, especificamente, a cada órgão que pretende organizar. As questões relativas ao Direito Internacional foram designadas às esferas de competências do STF, STJ, Justiça Federal e Justiça do Trabalho. Essas, por sua vez, são divididas didaticamente neste tópico, de acordo com a matéria que regulam: controle de constitucionalidade de tratados internacionais, cooperação jurídica internacional e contencioso envolvendo elementos de DIP.

O primeiro tema se refere ao controle de constitucionalidade de tratados internacionais. O art. 102, inciso III, alínea "b” da Constituição Federal de 1988 estabelece que o Supremo Tribunal Federal é competente para julgar, mediante recurso extraordinário, as causas que declararem a inconstitucionalidade de tratados internacionais. Ademais, é pacífico o entendimento de que pode incidir, também, o controle

\footnotetext{
${ }^{470}$ BRASIL. Constituição da República Federativa do Brasil de 1988. 25. ed. São Paulo: Revista dos Tribunais, 2005, art. 84, inciso VII, combinado com o art. 52, inciso IV.

${ }^{471}$ Id., ibid., art. 22, inciso VIII, combinado com os arts. 153, incisos I e II, e art. 237.

${ }^{472}$ Id., ibid., art. 22, incisos XIII e XV.

${ }^{473}$ Id., ibid., art. 48, inciso V.

${ }^{474}$ DALlARI, Pedro. Constituição e Relações Exteriores. Prefácio de Celso Lafer. São Paulo: Saraiva, 1994. p. 16; PANNUNZIO, Eduardo. A judicialização das relações internacionais no Brasil em face do princípio constitucional da prevalência dos direitos humanos. Tese de doutorado. Faculdade de Direito da Universidade de São Paulo, 2012. p. 73.
} 
concentrado $^{475}$, no qual o tribunal vai analisar a validade do Decreto Legislativo e do Decreto de Promulgação do tratado. O problema fundamental está no fato de que os efeitos desse controle afetam o conteúdo da norma internacional, gerando uma lacuna: o tratado não mais é válido no plano interno, contudo, permanece em vigor para o Brasil no plano internacional, pois a desvinculação se daria, geralmente, pela denúncia ${ }^{476}$.

Ademais, a Convenção de Viena sobre o Direito dos Tratados, de 1969 - ratificada pelo Brasil em 25 de setembro de 2009 e promulgada em 14 de dezembro do mesmo ano estabelece em seu art. $27^{477}$ que nenhum Estado pode se escusar de cumprir um tratado alegando disposições de direito interno, excetuando-se o caso em que há inconstitucionalidade extrínseca no ato de expressão do consentimento, conforme o art. $46^{478}$ da mesma Convenção.

RAMOS aponta duas soluções para esse problema. A primeira, e mais harmônica com os preceitos do DIP, seria apresentar uma Ação Direta de Constitucionalidade do tratado antes mesmo de o Brasil ratificá-lo, usando como objeto o Decreto Legislativo que aprova o texto $^{479}$. A segunda seria a modulação dos efeitos da declaração de inconstitucionalidade, pois, tendo em vista o risco de expor o Estado brasileiro a um ilícito internacional, o STF, por maioria de dois terços de seus membros, poderia determinar que sua decisão só tem eficácia depois que o tratado for denunciado, estabelecendo um prazo para que o Executivo assim proceda ${ }^{480}$.

\footnotetext{
${ }^{475}$ SUPREMO TRIBUNAL FEDERAL. Ação Direta de Inconstitucionalidade $\mathbf{n}^{\circ}$ 1480/DF - Medida Cautelar em Ação Direta de Inconstitucionalidade. Min. Rel. Celso de Mello. Julgado em 04.09.1997.

476 "É certo que a declaração de inconstitucionalidade de atos de aprovação e de promulgação de Tratado provoca uma situação política assaz complicada no plano internacional. Daí a necessidade de alguma reflexão sobre o tema." (MENDES, Gilmar Ferreira; BRANCO, Paulo Gustavo Gonet. Curso de Direito Constitucional. 8. ed. rev. e atual. São Paulo: Saraiva, 2013. p. 1129).

477 "Art. 27. Direito Interno e observância de tratados. Uma parte não pode invocar as disposições de seu direito interno para justificar o inadimplemento de um tratado. Esta regra não prejudica o artigo 46." (CONVENÇÃO DE VIENA SOBRE O DIREITO DOS TRATADOS, 1969).

478 "Art. 46. Disposições do Direito Interno sobre Competência para Concluir Tratados. 1. Um Estado não pode invocar o fato de que seu consentimento em obrigar-se por um tratado foi expresso em violação de uma disposição de seu direito interno sobre competência para concluir tratados, a não ser que essa violação fosse manifesta e dissesse respeito a uma norma de seu direito interno de importância fundamental. 2. Uma violação é manifesta se for objetivamente evidente para qualquer Estado que proceda, na matéria, de conformidade com a prática normal e de boa fé." (Id,, ibid., 1969).

479 "Com isso, a mera autorização congressual por meio do Decreto Legislativo gera o interesse de agir de algum dos colegitimados do art. 103 da Constituição para confirmar a constitucionalidade desse diploma, para evitar a incerteza, dar celeridade e, no caso dos tratados, evitar a futura responsabilidade internacional do Brasil. Todos esses objetivos por certo são compatíveis com o espírito do constituinte derivado que inspirou a criação da ADC." (RAMOS, André de Carvalho. Pluralidade das ordens jurídicas: a relação do direito brasileiro com o direito internacional. Curitiba: Juruá, 2012. p. 62).

${ }^{480}$ Id., ibid., p. 63.
} 
Quanto às competências relativas à cooperação jurídica internacional, a CF/88 dividiu as suas funções, delegando ao STF a análise da extradição ${ }^{481}$; ao STJ - após a Emenda Constitucional $\mathrm{n}^{\circ}$ 45, de 2004 - a homologação de sentenças estrangeiras e a concessão de exequatur às cartas rogatórias ${ }^{482}$; e ao juiz federal a sua execução ${ }^{483}$. Esses dispositivos devem sempre ser interpretados sob a luz do princípio da cooperação entre povos para o progresso da humanidade ${ }^{484}$, e também do princípio da efetividade do poder jurisdicional, diante das novas contingências do mundo globalizado ${ }^{485}$.

Por fim, em relação às normas que estabelecem competências sobre questões contenciosas que envolvem elementos de Direito Internacional, a CF delegou ao STF a de processar e julgar originariamente litígio entre Estado estrangeiro ou OI e a União, Estado, Distrito Federal ou Território ${ }^{486}$. Ao STJ foram atribuídas: a de julgar em sede de recurso ordinário, as causas em que forem partes Estados estrangeiros ou OIs, de um lado, e município ou pessoa residente e domiciliada no país, de outro; e a de julgar em sede de recurso especial as causas que contrariarem tratado internacional ou negar-lhe vigência ${ }^{487}$. Aos tribunais e juízes federais compete julgar: as causas entre Estado, OI e município ou pessoa domiciliada ou residente no Brasil; as causas fundadas em tratado ou contrato da União com Estados estrangeiros ou OIs; os crimes previstos em tratados, desde que iniciada a execução em território nacional; os crimes de ingresso; e causas referentes à nacionalidade $^{488}$. E aos tribunais e juízes do trabalho, processar e julgar as ações oriundas da relação de trabalho com entes de direito público externo ${ }^{489}$.

Muito embora a Constituição Federal de 1988 tenha delegado aos tribunais internos a competência para julgar causas em que as partes sejam Estados estrangeiros e Organizações Internacionais, é fundamental lembrar que esses gozam de imunidade de jurisdição e execução ${ }^{490}$. É certo que a de jurisdição já não é mais considerada absoluta,

\footnotetext{
${ }^{481}$ BRASIL. Constituição da República Federativa do Brasil de 1988. 25. ed. São Paulo: Revista dos Tribunais, 2005, art. 102, inciso I, alínea "g".

${ }^{482}$ Id., ibid., art. 105, inciso I, alínea "i”".

${ }^{483}$ Id., ibid., art. 109, inciso X.

${ }^{484}$ Id., ibid., art. $4^{\circ}$, inciso IX.

485 SUPERIOR TRIBUNAL DE JUSTIÇA. Carta Rogatória n 438-BE. Rel. Min. Luiz Fux. Julgado em 24.09.2007.

${ }^{486}$ BRASIL. Constituição da República Federativa do Brasil de 1988, art. 102, inciso I, alínea "e".

${ }^{487}$ Id., ibid., art. 105, inciso II, alínea "c" e inciso III, alínea "a".

${ }^{488}$ BRASIL. Constituição da República Federativa do Brasil de 1988, art. 109, incisos II, III, V e X.

${ }^{489}$ Id., ibid., art. 114, inciso I.

${ }^{490}$ Vide: SOARES, Guido Fernando Silva. Das imunidades de jurisdição e de execução. Rio de Janeiro: Forense, 1984.
} 
podendo existir o processo de conhecimento, no entanto, não haverá a possibilidade de execução $^{491}$, salvo se o Estado ou a OI desejar fazê-lo voluntariamente.

A competência da Justiça Federal para julgar causas fundadas em tratado internacional merece maior atenção, pois se trata de um recurso que pode ser melhor utilizado na busca pela tutela jurisdicional de uma série de temas que vão desde comércio internacional à proteção do meio ambiente. Importa, contudo, o alerta para que os juízes federais procurem se inteirar sobre o instrumento que deverão aplicar, de maneira que o façam em consonância com a interpretação internacional, sob pena de criar tratados internacionais de conteúdo brasileiro ${ }^{492}$. Não obstante, uma vez ratificados, os tratados fazem parte do arcabouço normativo que envolve o Estado brasileiro, podendo ser invocados, em tese, em todas as instâncias e esferas jurisdicionais e, também, administrativas.

Finalmente, como já mencionado acima, a constitucionalização de normas relativas à atuação do Brasil nas suas relações internacionais abriu a possibilidade de um controle judicial dos atos de política externa. Pannunzio defende que esse controle pode ser feito mediante declaração de inconstitucionalidade, obrigação de fazer e não fazer, questionamento de atos preparatórios internos, promoção da publicidade e responsabilização dos agentes públicos ${ }^{493}$. Dessa forma, sempre que o Estado brasileiro agir em dissonância com o estabelecido constitucionalmente, poderá ser questionado judicialmente, o que demandará do juiz a determinação da conduta a ser seguida, de acordo com a ordem jurídica, realizando assim o Império do Direito em todas as esferas da política, tirando as relações exteriores das sombras da "razão de Estado"494.

\footnotetext{
491 SUPREMO TRIBUNAL FEDERAL. RE. 222.368/PE. Rel. Min. Celso de Mello. Julgado em 30.04.2002.

${ }^{492}$ Ramos cita o exemplo da aplicação dos tratados internacionais de direitos humanos, em especial a Convenção Americana de Direitos Humanos: "Por exemplo, era possível um determinado Tribunal Superior brasileiro invocar as garantias processuais penais à luz da Convenção Americana de Direitos Humanos (arts. $8^{\circ}$ e 25) e sequer citar um precedente de interpretação da Corte Interamericana de Direitos Humanos, criando uma Convenção Americana de Direitos Humanos Paralela ou, ainda, uma verdadeira Convenção Americana de Direitos Humanos Brasileira.” (RAMOS, André de Carvalho. A pluralidade das ordens jurídicas e a nova centralidade do Direito Internacional. Boletim da Sociedade Brasileira de Direito Internacional. Ano XCVIII, ago./dez. 2013, v. 1, n. 119-24. p. 37).

${ }^{493}$ PANNUNZIO, Eduardo. A judicialização das relações internacionais no Brasil em face do princípio constitucional da prevalência dos direitos humanos. Tese de doutorado. Faculdade de Direito da Universidade de São Paulo, 2012. pp. 168-77, passim.

${ }^{494}$ Id., ibid., p. 150.
} 


\subsubsection{Disciplina constitucional da hierarquia das normas de Direito Internacional}

Nos ordenamentos jurídicos internos, a questão da posição hierárquica das normas internacionais é definida, em geral, pelas Constituições. Cassese identificou quatro tendências nas Constituições modernas quanto à abordagem do Direito Internacional e sua normativa. A primeira diz respeito a uma pequena quantidade de Estados ocidentais que fazem menção expressa a essas normas e estabelecem sua aplicação nos direitos internos, sendo que alguns deles até atribuem ao costume internacional um status superior. A segunda diz respeito às muitas constituições, principalmente do então chamado "terceiro mundo" e do bloco socialista, que simplesmente ignoram a existência do DIP. A terceira, por sua vez, engloba alguns países em desenvolvimento que fazem referências ao costume e aos princípios em suas constituições, demonstrando algum grau de aceitação. E, por fim, a quarta compreende um grande número de países, principalmente do dito "terceiro mundo", que ao invés de se referirem ao Direito Internacional de forma geral em seus textos fundamentais, referem-se às Nações Unidas ou única e tão somente à Carta das Nações Unidas ${ }^{495}$.

$\mathrm{Na}$ história constitucional brasileira, apenas na Constituição de 1988 houve a inserção, ainda que de forma bastante indireta, de preceitos relacionados ao tema da recepção de normas internacionais e seus efeitos ${ }^{496}$. O foco da disciplina constitucional foi todo direcionado aos tratados internacionais, mais especificamente aos de direitos humanos, olvidando-se das demais fontes do DIP. A inspiração para essa disciplina diferenciada pode ser considerada o princípio da prevalência dos direitos humanos, estabelecido no art. $4^{\circ}$, inciso II, que fundamenta a existência dos parágrafos $2^{\circ}$ e $3^{\circ}$ do art. $5^{\circ 497}$.

\footnotetext{
${ }^{495}$ CASSESE, Antonio. Modern constitutions and international law. RCADI, 1985-III, t. 192, pp. 331476. p. 368.

${ }^{496}$ DALLARI, Pedro B. A. Constituição e tratados internacionais. São Paulo: Saraiva, 2003. p. 47.

497 “Ou seja, a prevalência dos direitos humanos como princípio norteador das relações exteriores do Brasil e fundamento colimado pelo país para a regência da ordem internacional não implica tão somente o engajamento no processo de edificação de sistemas de normas vinculados ao Direito Internacional Público. Impõe-se buscar a plena integração das regras de tais sistemas à ordem jurídica interna de cada Estado, o que ressalta a importância do já mencionado $\S 2^{\circ}$ do art. $5^{\circ}$ da Constituição brasileira de 1988 , que dá plena vigência aos direitos e garantias decorrentes 'dos tratados internacionais em que a República Federativa do Brasil seja parte'.” (DALLARI, Pedro. Constituição e relações exteriores. Prefácio de Celso Lafer. São Paulo: Saraiva, 1994. p. 162). "O disposto no art. $5^{\circ}$ (2) da Constituição Brasileira de 1988 se insere na nova tendência de constituições latino-americanas recentes de conceder um tratamento especial ou diferenciado, também no plano do direito interno aos direitos e garantias individuais internacionalmente consagrados."
} 
Esses dispositivos causaram grande divergência de interpretações na doutrina e na jurisprudência sobre o lugar dos tratados na ordem jurídica brasileira. Hoje, passados mais de 25 anos de debates, instaurou-se certa pacificação quanto aos tratados internacionais, os quais possuem três diferentes status. Ou seja, o tratado de direitos humanos que for aprovado pelo rito estabelecido no parágrafo $3^{\circ}$ do art. $5^{\circ}$ da $\mathrm{CF} / 88$ será considerado uma Emenda Constitucional. Os demais tratados de direitos humanos possuem estatura supralegal, estando acima da lei ordinária e abaixo da Constituição Federal ${ }^{498}$. Todos os outros tratados são equivalentes à lei ordinária ${ }^{499}$.

Sob a luz do Direito Internacional não importa essa estratificação dos tratados no ordenamento jurídico interno, o que vale é o cumprimento do compromisso assumido, de acordo com o princípio do pacta sunt servanda. É exatamente neste ponto que os entendimentos supracitados podem vir a ser prejudiciais para o Estado brasileiro como um todo, podendo ser usado o argumento que, em se tratando de lei ordinária, um determinado tratado internacional pode ser revogado por lei posterior, deixando-o aparentemente sem efeitos no plano interno, embora continue em vigor. Instaura-se aqui o mesmo problema mencionado no tópico anterior, quando discutido o controle de constitucionalidade.

Para MELLO essa posição revela um "atraso monumental” do Brasil em relação aos seus pares na sociedade internacional. A tendência ditada pelo Recurso Extraordinário $\mathrm{n}^{\circ}$ 80.004, de 1977 foi, segundo o autor, um erro que o STF não tem coragem de corrigir $^{500}$. MAGALHÃES, por sua vez, chama a atenção para o fato de que o Estado é uno e que a suspensão da aplicação de um tratado por uma decisão judicial gera a responsabilidade internacional ${ }^{501}$. O mesmo raciocínio se aplica caso o Poder Legislativo emita uma lei com a intenção de "revogar" um tratado. Logo, a lógica por trás dessa discussão não se sustenta.

Com a ratificação da Convenção de Viena sobre o Direito dos Tratados (CVDT), de 1969, a questão da estratificação hierárquica dos tratados internacionais no ordenamento jurídico brasileiro perde de vez o seu sentido. A CVDT é muito clara no sentido que: em primeiro lugar, o ato que vincula o Estado ao tratado é a ratificação que se concretiza com

(CANÇADO TRINDADE, Antônio Augusto. Tratado de Direito Internacional dos direitos humanos. Porto Alegre: Sergio Antonio Fabris, 1997, v. I. p. 407).

498 SUPREMO TRIBUNAL FEDERAL. RE 466.343. Rel. Min. Cesar Peluso, Brasília. Julgado em 03.12.2008.

${ }^{499}$ SUPREMO TRIBUNAL FEDERAL. RE 80.004. Rel. Min. Xavier de Albuquerque. Julgado em 01. 06. 1977.

${ }^{500}$ MELLO, Celso D. de Albuquerque. Curso de Direito Internacional Público. 14. ed. rev. e ampliada. Rio de Janeiro: Renovar, 2002, v. I. p. 123.

${ }^{501}$ MAGALHÃES, José Carlos de. O Supremo Tribunal Federal e o Direito Internacional: uma análise crítica. Porto Alegre: Livraria do Advogado, 2000. p. 61. 
o depósito ou troca dos instrumentos ${ }^{502}$; em segundo lugar, uma vez ratificado - e não pendendo condição, termo ou a superveniência de alguma causa de extinção - somente a denúncia desobriga o cumprimento do $\operatorname{tratado}^{503}$; e, em terceiro lugar, nenhuma escusa de direito interno será admitida para a violação de obrigação contida no texto ${ }^{504}$.

\subsubsection{Tensões entre Supremacia da Constituição e Prevalência do Direito Internacional}

Os principais problemas estudados até aqui são ilustrativos do conflito a que se destina este tópico. $\mathrm{O}$ estudo passa a tratar, doravante, do problema fundamental do qual decorrem as tensões entre o Direito Internacional e o direito interno, em especial o constitucional, pois ambos almejam a prevalência, a superioridade jurídica ${ }^{505}$. Tanto o Direito Constitucional Contemporâneo quanto o Direito Internacional passam por transições e se influenciam mutuamente, entretanto, com a maior penetração da normativa internacional no domínio que antes era reservado à regulação interna, é fatal que surjam colisões cada vez maiores e mais frequentes ${ }^{506}$.

De acordo com BARROSO, a supremacia da Constituição Federal é o princípio no qual se fundamenta o Direito Constitucional Contemporâneo, derivando dela os fundamentos que revelam a posição de preeminência do poder constituinte, a rigidez e o conteúdo material das normas constitucionais. É daqui que se extrai a ideia da superioridade jurídica da Carta Magna sobre todas as normas do sistema jurídico, sendo que as que colidirem com ela não podem subsistir, pois não possuem validade. Os mecanismos para assegurar essa supremacia são conhecidos como jurisdição constitucional, dentre os quais figura o controle de constitucionalidade ${ }^{507}$.

\footnotetext{
502 CONVENÇÃO DE VIENA SOBRE O DIREITO DOS TRATADOS, de 1969, art. 2 (1), alínea “b”.

${ }^{503}$ Id., ibid., arts. 54 a 64.

${ }^{504}$ Id., ibid., art. 27.

505 “[...] A tradicional percepção da Constituição como documento supremo, expressa na imagem do vértice de uma pirâmide, enfrenta o desafio doutrinário de um mundo onde convivem inúmeras fontes normativas superiores. Todas aspiram à primazia ou, no mínimo, à igualdade hierárquica, e dentre elas se incluem, além do próprio direito constitucional, também o direito internacional e o direito comunitário. [...].” (BARROSO, Luís Roberto. Curso de Direito Constitucional Contemporâneo: os conceitos fundamentais e a construção do novo modelo. 4. ed. São Paulo: Saraiva, 2013. p. 110).

506 “[...] A Constituição é a manifestação da soberania estatal e o DIP a sua negação ou, pelo menos, sua crescente limitação." (MELLO, Celso D. de Albuquerque. Direito Constitucional Internacional: uma introdução. Constituição de 1988 revista em 1995. Rio de Janeiro: Renovar, 1994. p. 32).

507 BARROSO, Luís Roberto. Curso de Direito Constitucional Contemporâneo: os conceitos fundamentiais e a construção do novo modelo. 4. ed. São Paulo: Saraiva, 2013. p. 106. Também Mendes e Branco afirmam: "O conflito de leis com a constituição encontrará solução na prevalência desta, justamente se a Carta Magna for produto do poder constituinte originário, ela própria elevando-se à condição de obra suprema, que inicia o ordenamento jurídico, impondo-se, por isso, ao diploma inferior com ela inconciliável. De acordo com a doutrina clássica, por isso mesmo, o ato contrário à Constituição sofre de nulidade
} 
A prevalência do Direito Internacional, por sua vez, é postulada desde o paradigmático parecer consultivo relativo aos interesses alemães na Alta Silésia, quando a Corte Permanente de Justiça Internacional declarou, sob o ponto de vista do DIP, ser o direito interno "mero fato" prática internacional das últimas décadas, sendo constantemente reafirmado na jurisprudência dos tribunais internacionais.

Essa tensão entre supremacia da Constituição e prevalência do Direito Internacional já foi alvo de estudos por parte tanto de internacionalistas quanto de constitucionalistas e o resultado desses trabalhos mostra que não se trata de um conflito insolúvel. Muito pelo contrário, se observado atentamente mais parece um conflito superficial. De fato, são muitas e consistentes as teorias que os concilia, mas, na maioria do tempo, percebe-se que há uma harmonia entre as ordens constitucionais e a ordem internacional. As dissonâncias, quando surgem, podem ser superadas, e geralmente advêm de uma má compreensão da obrigatoriedade da norma internacional e da função de contribuir para o seu desenvolvimento por parte do intérprete nacional ${ }^{509}$.

MIRKINE-GUETZÉVITCH fez uma análise das relações entre o Direito Constitucional e o Direito Internacional na Academia de Haia, no ano de 1931. Para tal, adotou um método diferente dos autores que antes dele já tinham se debruçado sobre o tema das relações do DIP com os direitos internos. Primeiro, delimitou o alcance do seu trabalho, dizendo se tratar de algo menor, pois não falaria do direito interno como um todo, e sim, somente do Constitucional ${ }^{510}$. Depois, fez a diferenciação metodológica ao explicar que não usaria uma abordagem de prevalência desse ou daquele direito, mas faria uma abordagem de unidade, o que coaduna com a visão de que há uma unidade essencial do direito público ${ }^{511}$.

Já NEVES acredita que as relações entre as ordens jurídicas internacionais e estatais sofrem um momento de tensão, na medida em que o clássico paradigma da ratificação, como meio de contato entre elas, vem perdendo significado com a crescente incorporação de questões constitucionais no âmbito de competências dos tribunais

absoluta." (MENDES, Gilmar Ferreira; BRANCO, Paulo Gustavo Gonet. Curso de Direito Constitucional. 8. ed. rev. e atual. São Paulo: Saraiva, 2013. p. 108).

${ }_{508}^{508}$ Vide Capítulo I, tópico 3, supra.

509 NOLLKAEMPER, André. National Courts and the International Rule of Law. Oxford: Oxford University Press, 2012. p. 10.

${ }^{510}$ MIRKINE-GUETZÉVITCH, Boris. Droit International et Droit Constitutionel. RCADI, 1931-IV, t. 38. pp. 307-465. p. 311-2.

${ }^{511}$ Id., ibid., pp. 317-8. 
internacionais, vinculando indivíduos e agentes do Estado ${ }^{512}$. Para a superação dessas tensões, o constitucionalista defende o desenvolvimento de novas formas de re-entry sob a perspectiva de relações recíprocas que abranjam "um aprendizado e um intercâmbio" entre essas experiências ${ }^{513}$. Por fim, conclui que há a necessidade de tratar as questões constitucionais de maneira menos provinciana, sem, contudo, levar à crença de uma última ratio do Direito Internacional ${ }^{514}$.

Sob o ponto de vista internacionalista, a principal questão se encontra no fato que a preterição da norma internacional em favor de norma interna pode levar ao cometimento de um ato ilícito internacional por parte do Estado, o que poderá levá-lo a ser responsabilizado internacionalmente ${ }^{515}$. Assim, um tribunal doméstico não pode resolver uma antinomia dessa classe adotando os tradicionais critérios cronológicos, da especialidade e da superioridade ${ }^{516}$, pois ao fazê-lo, usando como referência uma norma interna anterior, especial ou superior - como a constitucional - estará violando o Direito Internacional.

A caracterização de um determinado ato do Estado como internacionalmente ilícito é de competência exclusiva do Direito Internacional, sendo um princípio amplamente reconhecido no tema da responsabilidade internacional que o fato de agir em conformidade com o direito doméstico - mesmo sendo uma norma constitucional - não afasta a ilicitude do ato, caso viole norma internacional ${ }^{517}$.

\footnotetext{
512 “[...] Do ponto de vista da ordem estatal, o crescente envolvimento dos tribunais constitucionais nessas questões, nas quais o modelo clássico de ratificação vem paulatinamente perdendo significado, fortifica-lhes o caráter de problemas constitucionais referentes a direitos humanos ou fundamentais ou concernentes à questão de limitação e controle do poder, envolvendo pretensões que ultrapassam o âmbito de validade específico da ordem interna. Do ponto de vista da ordem internacional, isso significa a incorporação das questões constitucionais no âmbito de competência de seus tribunais, que passam a levantar a pretensão de decidir com caráter vinculatório imediato para agentes e cidadãos dos Estados." (NEVES, Marcelo. Transconstitucionalismo. São Paulo: WMF Martins Fontes, 2009. pp. 132-3).

${ }_{514}^{513}$ Id., ibid., pp. 133-4.

514 "Esses exemplos em torno do transconstitucionalismo entre ordens internacionais e ordens estatais apontam para a necessidade de superação do tratamento provinciano de problemas constitucionais pelos Estados, sem que isso nos leve à crença na ultima ratio do direito internacional público; não só aqueles, mas também este pode equivocar-se quando confrontado com questões constitucionais, inclusive com problemas de direitos humanos." (Id., ibid., p. 151).

515 "Article 1. Responsibility of a State for its internationally wrongful acts. Every internationally wrongful act of a State entails the international responsibility of that State." (INTERNATIONAL LAW COMISSION. Draft Articles on Responsibility of States for Internationally Wrongful Acts, with commentaries. Yearbook of the International Law Comission, 2001, v, II, part two. p. 32).

${ }^{516}$ BOBBIO, Norberto. Des critères pour résoudre les antinomies. Dialectica, 1964, v. 18, $n^{\circ}$ 1/4. pp. 237-8. p. 241.

${ }_{517}$ É o que diz o art. $3^{\circ}$ do Draft Articles on Responsability of States for Internationally Wrongful Acts, seguido pelo seguinte comentário: "Article 3 makes explicit a principle already implicit in article 2, namely that the characterization of a given act as internationally wrongful is independent of its characterization as lawful under the internal law of the State concerned. There are two elements to this. First, an act of a State cannot be characterized as internationally wrongful unless it constitutes a breach of an international
} 
Ademais, os Estados ainda gozam de ampla liberdade para se obrigarem a uma determinada norma internacional, principalmente se essa for convencional. Fica difícil sustentar, de boa fé, o não cumprimento de uma determinada disposição em um tratado, alegando que esse viola a Constituição. Ora, o Estado negociou o texto, assinou, submeteuo ao Poder Legislativo - que deveria ter feito um controle preventivo de constitucionalidade - e ainda ratificou com a possibilidade de impor reservas, se for permitido. Ainda assim, se a interpretação dessa norma evoluir para contornos que não coadunam com disposições constitucionais do Estado, esse ainda possui a faculdade de denunciar o tratado, ou de se adequar à nova realidade junto com suas obrigações internacionais.

Mesmo assim, essas dissonâncias ocorrem com certa frequência. Para superá-las, RAMOS sugere a adoção de algumas alternativas hermenêuticas, fundadas no "princípio da cooperação leal com o Direito Internacional" ${ }^{\prime 518}$. São essas: a observação do princípio da interpretação internacionalista pelos juízes brasileiros, o princípio do espaço constitucional de conformação aos tratados internacionais, a presunção de aplicação de tratados preexistentes e dos não autoaplicáveis, o reconhecimento de um bloco de constitucionalidade, o uso retórico e argumentativo das razões de decidir internacionais como fundamentação de decisões nacionais, e o uso das leis e decisões internas para influenciar a gênese e interpretação do Direito Internacional ${ }^{519}$. Além disso, propõe a efetivação de um diálogo das cortes internas com as internacionais e a adoção de um duplo controle de leis e atos internos, observando a constituição e as obrigações internacionais, conforme são interpretadas pelos órgãos internacionais competentes ${ }^{520}$.

A adoção de métodos interpretativos, portanto, que levem em conta também as obrigações internacionais do Estado brasileiro (princípio da interpretação consistente) é a

obligation, even if it violates a provision of the State's own law. Secondly and most importantly, a State cannot, by pleading that its conduct conforms to the provisions of its internal law, escape the characterization of that conduct as wrongful by international law. An act of a State must be characterized as internationally wrongful if it constitutes a breach of an international obligation, even if the act does not contravene the State's internal law-even if, under that law, the State was actually bound to act in that way." (INTERNATIONAL LAW COMISSION. Draft Articles on Responsibility of States for Internationally Wrongful Acts, with commentaries. Yearbook of the International Law Comission, 2001, v, II, part two. p. 36).

518 “Esse princípio decorre do princípio do Estado Democrático de Direito, da cooperação entre os povos para o progresso da humanidade e, também, dos dispositivos espalhados da Constituição que fazem, como vimos, expressa referência a tratados como espécie normativa autônoma. Assim, a vontade do constituinte foi, ao menos, que se buscasse como regra, a conciliação entre os dispositivos internos e os dispositivos dos tratados." (RAMOS, André de Carvalho. Pluralidade das ordens jurídicas: a relação do direito brasileiro com o direito internacional. Curitiba: Juruá, 2012. p. 69).

${ }^{519}$ RAMOS, André de Carvalho. Pluralidade das ordens jurídicas: a relação do direito brasileiro com o direito internacional. Curitiba: Juruá, 2012, pp. 67-74, passim.

${ }^{520}$ Vide tópico 1, supra. 
chave para evitar os conflitos entre a supremacia da Constituição e a prevalência do Direito Internacional. Demonstrou-se aqui que não há choques graves e insolúveis entre ambos, mas sim que esses são abordados de forma equivocada pelos juízes nacionais que, muitas vezes, desconsideram o fato de terem que observar a aplicação do DIP de acordo com a interpretação internacionalista, sob pena de ensejar em um ato ilícito internacional, mesmo que esse esteja em perfeita consonância com a Carta Magna.

\subsubsection{Tribunais Internacionais na Constituição Federal de 1988}

À época da Assembleia Constituinte, o Brasil era parte de apenas dois tribunais internacionais permanentes: a Corte Permanente de Arbitragem e a Corte Internacional de Justiça $^{521}$. Hoje, passados mais de 25 anos, o Estado brasileiro é parte de mais cinco desses tribunais: Corte Interamericana de Direitos Humanos ${ }^{522}$, Tribunal Internacional para o Direito do $\mathrm{Mar}^{523}$, Tribunal Penal Internacional ${ }^{524}$, Tribunal Permanente de Revisão do Mercosul $^{525}$ e Órgão de Apelação do Sistema de Solução de Controvérsias da Organização Mundial do Comércio ${ }^{526}$.

A Constituição Federal de 1988, no entanto, traz em apenas dois artigos referências expressas a tribunais internacionais. O primeiro deles, o art. $7^{\circ}$ do Ato de Disposições Constitucionais Transitórias (ADCT), expressa que o "Brasil propugnará pela formação de um Tribunal Internacional de Direitos Humanos”. Já o segundo - inserido pela Emenda Constitucional $\mathrm{n}^{\circ} 45 / 2004$, no seu art. $5^{\circ}$, parágrafo $4^{\circ}$ - estabelece que o Brasil "se submete à jurisdição do Tribunal Penal Internacional a cuja criação tenha manifestado adesão".

A falta de disposições constitucionais mais consistentes em matéria de tribunais internacionais poderia levar a questionamentos quanto à validade das suas decisões no ordenamento jurídico interno. Contudo, o fundamento que legitima constitucionalmente a adesão brasileira a esses órgãos judiciais internacionais é o inciso VII do art. $4^{\circ}$ da $\mathrm{CF} / 88$,

\footnotetext{
521 CARTA DAS NAÇÕES UNIDAS E ESTATUTO DA CORTE INTERNACIONAL DE JUSTIÇA. Decreto n. 19.841, 22 de outubro de 1945.

522 CONVENÇÃO AMERICANA SOBRE DIREITOS HUMANOS. Decreto n. 678, 6 de novembro de 1992. Reconhecimento da competência contenciosa em 10 de dezembro de 1998.

${ }^{523}$ CONVENÇÃO DAS NAÇÕES UNIDAS SOBRE O DIREITO DO MAR. Decreto n. 99.165, de 12 de março de 1990.

${ }^{524}$ ESTATUTO DE ROMA. Decreto n. 4.388, de 25 de setembro de 2002.

${ }^{525}$ PROTOCOLO DE OLIVOS. Decreto n. 4.982, de 9 de fevereiro de 2004.

${ }^{526}$ ACORDO CONSTITUTIVO DA ORGANIZAÇÃO MUNDIAL DO COMÉRCIO. Decreto n. 1.355, de 30 de novembro de 1994.
} 
o qual dispõe que o Brasil deverá se reger nas suas relações exteriores pelo princípio da solução pacífica de controvérsias.

Se os tribunais internacionais são a expressão evolutiva máxima do princípio da solução pacífica de controvérsias no Direito Internacional, o enunciado dessa norma constitucional impõe ao Estado brasileiro a observância dos ditames oriundos das jurisdições internacionais. Como demonstrado anteriormente, esse princípio possui eficácia direta e interpretativa, ou seja, incide na realidade como se fosse regra e serve de norte para interpretação das demais normas do ordenamento ${ }^{527}$. Quando se analisa os tribunais internacionais de direitos humanos, o princípio da prevalência dos direitos humanos deve ser aplicado em conjunto, reforçando ainda mais a força normativa de suas decisões no direito brasileiro. O mesmo vale para os tribunais dos blocos de integração regionais de que o Brasil faz parte, por força do parágrafo único do art. $4^{\circ}$.

Ainda assim, alguns problemas podem ser levantados quando diante de tribunal cujo tratado constitutivo prevê normas que conflitam com o texto constitucional, como foi o caso do Estatuto de Roma do Tribunal Penal Internacional. A inserção do parágrafo $4^{\circ}$ no art. $5^{\circ}$ da $\mathrm{CF} / 88$ foi importante para dirimir qualquer problemática relativa à compatibilidade do Estatuto com o direito brasileiro. Questões como a entrega de nacionais, a prisão de caráter perpétuo e a imunidade de chefes de Estado, que constam no tratado e que colidiam frontalmente com a $\mathrm{CF} / 88$, a partir daí foram superadas. Assim, não só o Estatuto como a própria jurisdição do TPI e as decisões que dela decorrem estão em perfeita sincronia com ordenamento jurídico nacional ${ }^{528}$.

O alcance do princípio da solução pacífica de controvérsias, constante no art. $4^{\circ}$, por si só é o fundamento jurídico constitucional para a promoção da efetividade das jurisdições internacionais e, consequentemente, das decisões que dela derivam. Ora, essas são instrumentos fundamentais para o exercício daquelas e sua negação implicaria em um fracasso desse meio de solução pacífica de disputas, que são os tribunais internacionais. Desse modo, garantir o devido cumprimento das decisões é um mandamento internacional e também constitucional, que vincula todos os Poderes do Estado e possui como guardião o Poder Judiciário brasileiro.

\footnotetext{
${ }^{527}$ Vide tópico 2 deste capítulo.

${ }^{528}$ PIOVESAN, Flávia. IKAWA, Daniela Ribeiro. O Tribunal Penal Internacional e o Direito Brasileiro. In: PIOVESAN, Flávia. Temas de Direitos Humanos. 3. ed. São Paulo: Saraiva, 2009. p. 167.
} 


\subsubsection{Reflexões sobre a observância e a execução de decisões judiciais internacionais pelo Poder Judiciário Brasileiro: aplicação dos mecanismos de comunicação e sua eficácia}

\subsubsection{Considerações preliminares}

O histórico de atuação do Brasil em tribunais internacionais não é muito extenso. Muito embora seja parte da Corte Permanente de Arbitragem desde 1907, tendo sido também membro da Corte Permanente de Justiça Internacional, pouquíssimos foram os casos em que o Estado brasileiro figurou em um dos pólos do processo internacional ${ }^{529}$. Foi somente na primeira década do século XXI que a litigância internacional do Estado brasileiro se expandiu, o que fez com que esse se visse diante da obrigação de cumprir decisões judiciais internacionais e observar a jurisprudência internacional.

A execução, cumprimento ou implementação das decisões judiciais internacionais pode ser efetuada por atos dos Poderes Executivo, Legislativo e Judiciário. Caso os primeiros se mantiverem inertes, entretanto, caberá ao último, mediante provocação, promover os atos necessários ${ }^{530}$. Os legitimados para promover a ação judiciária cabível são o Ministério Público (Estadual ou Federal, de acordo com suas competências), os interessados na questão e, no caso das decisões da Corte Interamericana de Direitos Humanos, a vítima. O foro será aquele de competência para a matéria a qual a decisão se destina, contudo, se essa não for claramente delimitada, salvo melhor juízo, prevalece a regra do art. 109, III da CF/88, atraindo a causa para a Justiça Federal de primeiro grau.

Algumas tensões podem ser observadas na execução das decisões judiciais internacionais pelo Poder Judiciário brasileiro. Isso se dá em razão de que o procedimento de execução em cada Estado ocorre conforme as suas regras processuais ${ }^{531}$, salvo se a

\footnotetext{
${ }^{529}$ Faz-se fundamental a menção de todo histórico brasileiro no campo da arbitragem desde o começo do Império, bem como o caso dos Empréstimos Brasileiros (França v. Brasil, 1929) no qual o Brasil foi condenado na antiga CPJI. Nesse sentido vide: ACCIOLY, Hildebrando. Tratado de Direito Internacional Público. São Paulo: Quartier Latin, 2009, v. III. pp. 67-93; COUR PERMANENTE DE JUSTICE INTERNATIONALE. Affaire rélative au paiement, en or, des Emprunts Federaux Brésiliens Émis en France. Arrêt du 12 juillet 1929. Série A, nº 15.

${ }^{530}$ RAMOS, André de Carvalho. Processo Internacional de Direitos Humanos. Análise dos sistemas de apuração de violações de direitos humanos e a implementação das decisões no Brasil. São Paulo: Saraiva, 2012. p. 383.

531 "La procédure à travers laquelle dês arrêts et des décisions internationaux sont mis en oeuvre dans um ordre étatique ne peut être dictée que par les régles de procédure en vigueur dans ce pays. C'est lá une limite ultérieure à l'observance uniforme et parfaite de ces actes internationaux dans les différents pays. Toutefois, les instruments internationaux prévoyant que des arrêts ou des décisions soient rendus essaient parfois eux-mêmes de réglementer en quelque sorte de façon uniforme même la phase de l'exécution nationale des actes." (GIARDINA, Andrea. La mise en oeuvre au niveau national des arrêts et des décisions internationaux. RCADI, 1979-IV, t. 165. p. 301).
} 
própria decisão internacional estipular o contrário. No caso dos tribunais brasileiros, podese identificar como potenciais causas de conflito: a litispendência interna, a existência de prescrição ou anistia - nos casos em que é determinada a abertura de investigações ou processos penais -, a entrega de nacionais ao TPI (procedência do pedido e a competência), o óbice da coisa julgada e o interesse de terceiros prejudicados.

A litispendência interna só poderá acontecer, em teoria, quando o Brasil estiver diante de uma decisão de Pronta Libertação de Embarcações e Tripulações do Tribunal Internacional para o Direito do Mar que, conforme discutido, poderá correr ao mesmo tempo em que haja ações de mesmo objeto nos tribunais internos ${ }^{532}$. No caso Camouco (Panamá v. França, em 2000), diante de uma alegação de litispendência feita pela França, o Tribunal alegou que a Pronta Libertação não era uma apelação contra a decisão de uma corte francesa, e sim um remédio independente com um pequeno prazo para interposição, o que não possibilitaria o prévio esgotamento dos recursos internos ${ }^{533}$. Logo, a própria jurisprudência internacional afasta de plano essa alegação.

Nos casos de decisões em que um tribunal internacional determina a instauração de processo criminal contra algum indivíduo, ou indivíduos, o Judiciário brasileiro pode impor o óbice da prescrição do crime, segundo o direito interno, ou da existência de lei de anistia. Contra essas alegações, a jurisprudência internacional é clara no sentido de que as leis de autoanistia são inválidas, pois colidem com o direito de acesso à justiça das vítimas, e os crimes considerados contra a humanidade são imprescritíveis, em razão de uma série de tratados e também do costume internacional ${ }^{534}$.

Outra questão que, no futuro, pode vir a ser um entrave nas relações do Poder Judiciário brasileiro com um tribunal internacional é a da possível detenção e entrega de nacionais ao TPI. Muito embora a doutrina e o próprio Estatuto de Roma já tenham esclarecido essa questão ao enfatizar que o instituto da "entrega" se diferencia,

\footnotetext{
${ }^{532}$ Todos os outros tribunais de que o Estado brasileiro faz parte dão primazia ao Judiciário interno para sanar a violação, seja pela adoção da regra do prévio esgotamento de recursos internos ou do princípio da complementaridade, o que afasta a possibilidade de concorrência com instâncias nacionais.

533 "Article 292 provides for an independent remedy and not an appeal against a decision of a national court. No limitation should be read into article 292 that would have the effect of defeating its very object and purpose. Indeed, article 292 permits the making of na application within a short period from the date of detention and it is not normally the case that local remedies could be exhausted in such a short period." (INTERNATIONAL TRIBUNAL FOR THE LAW OF THE SEA. The "Camouco" Case (Panama v. France). Application for Prompt Release. Judgment of 7 february 2000. § 58).

${ }^{534}$ Vide: CORTE INTERAMERICANA DE DIREITOS HUMANOS. Caso Barrios Altos vs. Peru. Mérito. Sentença de 14 de março de 2001. Série C, $\mathrm{n}^{\circ}$ 75; CORTE INTERAMERICANA DE DIREITOS HUMANOS. Almonacid Arellano y otros vs. Chile. Exceções preliminares, mérito, reparações e custas. Sentença de 26 de setembro de 2006. Série C, $\mathrm{n}^{\circ}$ 154; CORTE INTERAMERICANA DE DIREITOS HUMANOS. Caso Gomes Lund e outros ("Guerrilha do Araguaia") vs. Brasil. Exceções preliminares, mérito, reparações e custas. Sentença de 24 de novembro de 2010. Série C, nº 219.
} 
essencialmente, do da "extradição" ${ }^{535}$, e que a Emenda Constitucional n. 45, ao introduzir o parágrafo $4^{\circ}$ no art. $5^{\circ}$ da $\mathrm{CF} / 88$, já tenha dado um grande passo no sentido de solucionar toda e qualquer antinomia com o texto constitucional, ainda persiste a questão da competência.

Em decisão recente - que será melhor discutida posteriormente - o STF analisou o mandado do TPI de detenção e entrega do presidente sudanês Omar Al-Bashir ${ }^{536}$, submetido a ele como se fosse uma extradição, o que fez surgir a seguinte questão: teria o Pretório Excelso competência constitucional para analisar esse pedido? RAMOS entende que não, pois o rol do art. 102 da CF/88 é numerus clausus, só podendo ser expandido por reforma constitucional, o que prevê a competência para a extradição e não para a entrega. A competência para o conhecimento desse pedido seria, de acordo com o autor, do juiz federal de primeiro grau, conforme estipula o art. 109, inciso III da Carta Magna, cabendo a provocação ao Ministério Público Federal, caso necessário ${ }^{537}$.

Outro possível ponto de conflito na execução judicial das decisões de tribunais internacionais é o óbice da coisa julgada nacional. Isso porque um órgão judicial internacional, ao constatar a responsabilidade internacional do Estado, vai certamente estabelecer reparações que façam com que o ato ilícito seja sanado e as partes retornem ao mais próximo possível do status quo ante. Se a origem da responsabilidade for uma sentença judicial que tenha violado obrigação internacional, a decisão judicial internacional não pretende reformá-la, e sim reparar o dano causado por ela ${ }^{538}$.

Ademais, para que seja oposta a exceção da coisa julgada é necessário que haja a identidade das partes, do pedido e da causa de pedir entre as decisões "conflitantes" internas e internacionais. Obviamente que isso não acontecerá, uma vez que esses

\footnotetext{
535 Vide: RAMOS, André de Carvalho. O Estatuto do Tribunal Penal Internacional e a Constituição Brasileira. In: CHOUKR, Fauzi Hassam. AMBOS, Kai (Orgs.). Tribunal Penal Internacional. São Paulo: Revista dos Tribunais, 2000; PIOVESAN, Flávia; IKAWA, Daniela Ribeiro. O Tribunal Penal Internacional e o Direito Brasileiro. In: PIOVESAN, Flávia, Temas de direitos humanos. 3. ed. São Paulo: Saraiva, 2009. ${ }^{536}$ SUPREMO TRIBUNAL FEDERAL. Petição 4.625/ República do Sudão. Requerente: Tribunal Penal Internacional (Estatuto de Roma). Requerido: Omar Hassan Ahmad Al Bashir (Presidente do Sudão). Rel. Min. Rosa Webber. Decisão monocrática do Presidente em exercício Min. Celso Mello, publicada em 04.08.2009.

${ }^{537}$ RAMOS, André de Carvalho. O Estatuto do Tribunal Penal Internacional e a Constituição Brasileira. In: CHOUKR, Fauzi Hassam; AMBOS, Kai (Orgs.). Tribunal Penal Internacional. São Paulo: Revista dos Tribunais, 2000. p. 284. Vide também: RAMOS, André de Carvalho. Processo Internacional de Direitos Humanos. Análise dos sistemas de apuração de violações de direitos humanos e a implementação das decisões no Brasil. São Paulo: Saraiva, 2012. p. 288.

${ }^{538}$ RAMOS, André de Carvalho. Processo Internacional de Direitos Humanos. Análise dos sistemas de apuração de violações de direitos humanos e a implementação das decisões no Brasil. São Paulo: Saraiva, 2012. p. 385.
} 
elementos nunca coincidirão em sua totalidade entre causas domésticas e internacionais ${ }^{539}$. Dessa maneira, fica demonstrado que o óbice da coisa julgada também não deve ser um argumento para obstar a execução, cumprimento ou implementação de decisão judicial internacional pelo Poder Judiciário brasileiro.

Finalmente, um último possível problema relativo à plena efetivação das decisões judiciais internacionais é o Judiciário brasileiro constatar que essas violaram interesses de terceiros os quais sequer foram ouvidos pelos tribunais internacionais ${ }^{540}$. É o caso, por exemplo, das sentenças da Corte Interamericana de Direitos Humanos que determinam ao Estado a abertura de investigações e processos penais contra indivíduos que incorreram no ato ilícito internacional. Embora seja uma questão difícil que os tribunais internacionais, principalmente os de direitos humanos, deverão enfrentar ${ }^{541}$, as decisões internacionais são obrigatórias também aos terceiros e deverão ser efetivadas em sua integralidade ${ }^{542}$.

Analisadas e superadas as possíveis causas de conflito, o próximo passo será o estudo de alguns casos concretos no âmbito do Supremo Tribunal Federal, em que o Poder Judiciário brasileiro, em sua mais alta instância, viu-se diante de decisões de tribunais internacionais dos quais o Estado brasileiro é parte. O objetivo é mostrar como está ocorrendo a comunicação e se essa é dissonante ou harmônica. Nesse último caso, se possível, busca-se identificar o mecanismo de comunicação adotado. Por fim, será feita uma breve reflexão, baseada nos casos analisados. Para tanto, serão levadas em conta a influência que o STF possui sobre as demais instâncias a respeito das relações entre os tribunais internacionais e o Poder Judiciário brasileiro no que concerne às decisões judiciais internacionais.

\footnotetext{
539 GIARDINA, Andrea. La mise en oeuvre au niveau national des arrêts et des décisions internationaux. RCADI, 1979-V, t. 165. pp. 303-4.

540 "Os litígios internacionais quando envolvem questões de natureza civil ou administrativa, ou quando a decisão penal repercute na esfera civil, a sentença internacional pode alcançar interesses jurídicos de terceiros alheios ao processo internacional. Essa situação gera controvérsias em razão do conflito entre o respeito ao princípio do contraditório e a obrigatoriedade de cumprimento das sentenças internacionais." (MAEOKA, Érika. O Acesso à Justiça e os Desafios à Implementação das Sentenças da Corte Interamericana de Direitos Humanos. Dissertação de Mestrado. Universidade Estadual de Londrina, 2009. p. 144).

${ }^{541}$ Vide: RAMOS, André de Carvalho. Processo Internacional de Direitos Humanos. Análise dos sistemas de apuração de violações de direitos humanos e a implementação das decisões no Brasil. São Paulo: Saraiva, 2012. pp. 391-3.

542 MAEOKA, Erika. Op. cit., 2009, pp.144-5. A autora está desenvolvendo sua tese de doutorado na Faculdade de Direito da USP sobre a questão do "terceiro ausente".
} 
3.2.2.2 Opiniões consultivas da Corte Interamericana de Direitos Humanos e o Supremo Tribunal Federal: Extradição 954 e Recurso Extraordinário 511.961

Nesse tópico são analisadas situações em que o Supremo Tribunal Federal, ao decidir casos que envolviam a interpretação do direito brasileiro, consoante normas internacionais, recorreu diretamente à jurisprudência da Corte Interamericana de Direitos Humanos para fundamentar suas decisões ${ }^{543}$. Trata-se dos casos da Extradição 954, no tocante à questão da assistência consular, e do Recurso Extraordinário 511.961, sobre a exigência de diploma para o exercício da profissão de Jornalista.

No primeiro caso, em 24 de maio de 2005, o Ministro Joaquim Barbosa, em decisão monocrática do Processo de Extradição n ${ }^{\circ} 954^{544}$, mencionou, expressamente, a Opinião Consultiva $\mathrm{n}^{\circ} 16$, da Corte Interamericana de Direitos Humanos ${ }^{545}$ e, também, o caso La Grand da Corte Internacional de Justiça, para fundamentar sua decisão no sentido de que o extraditando tinha o direito de requerer assistência consular ${ }^{546}$. Recorreu, pois, às decisões judiciais internacionais mencionadas para reconhecer direito proveniente do plano internacional.

No segundo exemplo, em 2001, o Ministério Público Federal entrou com ação civil pública em face da União com vistas a impedir que o Ministério do Trabalho exigisse o diploma de Jornalista como condição para o exercício da profissão. O MPF fundamentou sua petição, utilizando-se, entre outros argumentos, da Opinião Consultiva $n^{\circ} 05$ da Corte Interamericana de Direitos Humanos, proferida em 13 de novembro de $1985^{547}$. A ação foi

\footnotetext{
${ }^{543}$ Vide: ARAÚJO, Nadia. A influência das Opiniões Consultivas da Corte Interamericana de Direitos Humanos no Ordenamento Jurídico Brasileiro. Revista CEJ. Brasília, n 29, abr./jun. 2005. pp. 64-9.

544 SUPREMO TRIBUNAL FEDERAL. Extradição 954/Itália. Requerente: Governo da Itália. Extraditando: Marcel Van den Berg. Julgado em 07.06.2006.

${ }^{545}$ CORTE INTERAMERICANA DE DIREITOS HUMANOS. O Direito a Informação sobre Assistência Consular no Marco das Garantias do Devido Processo Legal. Opinião Consultiva OC-16/99 de $1^{\circ}$ de outubro de 1999. Série A, nº16.

546 "A doutrina internacionalista, bem como a maciça jurisprudência de tribunais internacionais, tem enfatizado que existe um direito humano à solicitação de assistência consular (ver, a respeito, a decisão da Corte Internacional de Justiça no Caso La Grand (Germany vs. United States of America), de 27.06.2001, e a Opinião Consultiva 16 da Corte Interamericana de Direitos Humanos, de $1^{\circ} .10 .1999$, as quais contêm uma série de citações doutrinárias que corroboram essa tese. A assistência consular fica a cargo do Estado que decide prestá-la. A posição do Estado cujas autoridades detiveram o estrangeiro é de garantir que tal solicitação chegue às mãos do Estado estrangeiro e que o indivíduo tenha conhecimento de que a assistência consular pode por ele ser solicitada." (Id., ibid., 1999).

${ }^{547}$ CORTE INTERAMERICANA DE DIREITOS HUMANOS. A Coligação Obrigatória de Jornalistas (arts. 13 e 29 da Convenção Americana sobre Direitos Humanos). Opinião Consultiva OC-5/85, de 13 de novembro de 1985 . Série A, nº 5.
} 
julgada procedente em primeiro grau, reformada no Tribunal Regional Federal e chegou ao Supremo Tribunal Federal em sede de recurso extraordinário ${ }^{548}$.

Em 2009, o Recurso Extraordinário 511.961 foi julgado procedente e um dos fundamentos utilizados pelo relator, Ministro Gilmar Mendes, foi a Opinião Consultiva ${ }^{\circ}$ 05, da Corte Interamericana de Direitos Humanos, a qual, inclusive, citou extensivamente e de forma direta em seu voto ${ }^{549}$. Por fim, a ementa do acórdão dedica todo um parágrafo a essa decisão judicial internacional ${ }^{550}$.

Esses são perfeitos exemplos de casos em que houve a utilização do mecanismo de comunicação do diálogo das cortes ${ }^{551}$. Embora as opiniões consultivas sejam decisões judiciais internacionais que não vinculam os Estados, essas possuem uma autoridade inquestionável em determinar os contornos da aplicação das normas internacionais pelos tribunais internacionais. Desse modo, o STF, ao utilizar as OCs $n^{\circ} 05$ e 16 da Corte Interamericana de Direitos Humanos, interpretou o direito brasileiro de maneira consistente com suas obrigações internacionais, promovendo a compatibilização do ordenamento interno com a Convenção Americana de Direitos Humanos, de acordo os preceitos de sua intérprete natural. A comunicação nesses casos foi plenamente harmoniosa.

\footnotetext{
548 Vide: SUPREMO TRIBUNAL FEDERAL. RE 511.961. Rel. Min. Gilmar Mendes. Julgado em 17.06.2009.

${ }^{549}$ Id., ibid., fls. 769-83.

550 “8. JURISPRUDÊNCIA DA CORTE INTERAMERICANA DE DIREITOS HUMANOS. POSIÇÃO DA ORGANIZAÇÃO DOS ESTADOS AMERICANOS - OEA. A Corte Interamericana de Direitos Humanos proferiu decisão no dia 13 de novembro de 1985, declarando que a obrigatoriedade do diploma universitário e da inscrição em ordem profissional para o exercício da profissão de jornalista viola o art. 13 da Convenção Americana de Direitos Humanos, que protege a liberdade de expressão em sentido amplo (caso "La colegiación obligatoria de periodistas" - Opinião Consultiva OC-5/85, de 13 de novembro de 1985). Também a Organização dos Estados Americanos - OEA, por meio da Comissão Interamericana de Direitos Humanos, entende que a exigência de diploma universitário em jornalismo, como condição obrigatória para o exercício dessa profissão, viola o direito à liberdade de expressão (Informe Anual da Comissão Interamericana de Direitos Humanos, de 25 de fevereiro de 2009).” (Id., ibid., fls. 695).

551 Vide: RAMOS, André de Carvalho. O diálogo das Cortes: o Supremo Tribunal Federal e a Corte Interamericana de Direitos Humanos. In: AMARAL JUNIOR, Alberto do. JUBILUT, Liliana Lyra. (orgs.) $\mathbf{O}$ STF e o Direito Internacional dos Direitos Humanos. São Paulo: Quartier Latin do Brasil, 2009. pp. 80550.
} 
3.2.2.3 Caso dos pneus usados: ADPF 101, Laudo do Tribunal Arbitral ad hoc do Mercosul e Relatório do Órgão de Apelações do Sistema de Solução de Controvérsias da $\mathrm{OMC}$

Em 24 de junho de 2009, o Supremo Tribunal Federal julgou a Arguição de Descumprimento de Preceito Fundamental (ADPF) n. $101^{552}$, de autoria do Presidente da República, a qual buscava evitar e reparar lesão causada a preceito fundamental por decisões judiciais que violaram o art. 225 da $\mathrm{CF} / 88$. Essas decisões estavam sendo proferidas em contrariedade a portarias e resoluções dos órgãos reguladores do comércio exterior e do meio ambiente, que proibiam a importação de pneus usados de países que não eram membros do Mercosul. Alegou o requerente que a importação desses produtos feria a $\mathrm{CF} / 88$ e a Convenção da Basileia, colocando em risco o meio ambiente e a saúde dos brasileiros. Ademais, ainda havia o fato de que as liminares concedidas violavam as regras multilaterais do comércio, conforme constatado pela $\mathrm{OMC}^{553}$.

Em breve síntese, a questão remete ao ano de 2002, quando um tribunal arbitral ad hoc do Mercosul, constituído a pedido do Uruguai e sob a forma estabelecida nos Protocolos de Brasília e Outro Preto, determinou que as normativas brasileiras internas que proibiam a importação de pneumáticos remoldados feriam as regras comerciais do bloco e deveriam, portanto, serem reformadas ${ }^{554}$. Para dar cumprimento ao referido laudo, o Estado brasileiro passou a autorizar a importação desses produtos somente se provenientes dos países do Mercosul, o que fez com que várias empresas procurassem a Justiça e conseguissem, por meio de liminares, autorização para importação desses bens de países que não faziam parte do bloco econômico sulamericano.

Em decorrência disso, no ano de 2005, a União Europeia iniciou um procedimento de consultas em face do Brasil no Sistema de Solução de Controvérsias da OMC. Dois anos depois, a controvérsia chegou ao Órgão de Apelações, que acabou por adotar um relatório em que afirma ser justificável a proibição da importação de pneus usados sob a alegação de razões ambientais e de saúde pública. Constatou, contudo, que a permissão concedida aos pneus usados vindos de membros do Mercosul e aquelas autorizadas pela

\footnotetext{
${ }^{552}$ SUPREMO TRIBUNAL FEDERAL. Arguição de Descumprimento de Preceito Fundamental $\mathbf{n}^{\circ} 101 \%$ DF. Min. Rel. Carmém Lúcia. Julgado em 24.06.2009.

${ }^{553}$ Id., ibid., fls. 9-15.

554 MERCOSUL. Laudo do Tribunal Arbitral ad hoc do Mercosul constituído para entender da controvérsia apresentada pela República Oriental do Uruguai à República Federativa do Brasil sobre “Proibição de Importação de Pneumáticos Remoldados (Remolded) Procedentes de Uruguai". Adotado em Montevidéu, no dia 09 de janeiro de 2002. Disponível em: http://www.stf.jus.br/arquivo/cms/processo AudienciaPublicaAdpf101/anexo/LaudodoTribunalArbitralAdHocdoMERCOSUL.pdf. Acesso em: 28 dez. 2013.
} 
justiça brasileira violavam as regras multilaterais de comércio ao promover uma discriminação arbitrária ${ }^{555}$.

No seu voto, a relatora da ADPF 101 ressaltou a importância de o Poder Judiciário brasileiro se adequar ao estabelecido pelo Órgão de Apelações do Sistema de Solução de Controvérsias da $\mathrm{OMC}^{556}$. Além disso, citou de forma direta os relatórios adotados no transcorrer do processo internacional de solução de controvérsias, realçando as conclusões adotadas. Os ministros Joaquim Barbosa, Ellen Gracie e Gilmar Mendes também mencionaram o contencioso internacional em seus votos. Ademais, posteriormente no texto do acórdão, a obrigatoriedade das decisões judiciais internacionais perante o ordenamento jurídico brasileiro foi alvo de um breve, contudo significativo debate ${ }^{557}$.

Ao final, o STF concluiu pela procedência parcial da Ação, derrubando todas as liminares que autorizavam a importação dos pneus usados de outros países, contudo, mantendo a autorização para aqueles do Mercosul. Assim, cumpriu-se o determinado pelo tribunal ad hoc, mas se manteve a regra que o Órgão de Apelações da OMC considerou como "discriminação arbitrária".

O caso aqui analisado mostra a aplicação, ao mesmo tempo, dos mecanismos da subordinação e do diálogo das cortes. A subordinação se deu em relação à decisão do tribunal arbitral $a d$ hoc, o que ficou claro, inclusive na ementa do acórdão ${ }^{558}$. Já o diálogo das cortes pôde ser observado na extensa menção ao relatório do Órgão de Apelações do

${ }_{555}$ WORLD TRADE ORGANIZATION. Brazil - Measures Affecting Imports Of Retreaded Tyres. Report of the Appellate Body. AB- 2007-4. WT/DS332/AB/R. 3 December 2007.

556 "Aquela decisão convida o Judiciário nacional, em especial este Supremo Tribunal, a examinar e julgar a matéria no que concerne às providências, incluídas as normativas, adotadas no sentido de garantir a efetividade dos princípios constitucionais. Enfoque especial há de ser dado à questão das decisões judiciais contraditórias, realce àquelas listadas na peça inicial desta Arguição, mas que tem caráter meramente exemplificativo, à luz das obrigações internacionais do Brasil, mas principalmente e em razão da competência deste Supremo Tribunal, dos preceitos constitucionais relativos à saúde pública e à proteção ao meio ambiente ecologicamente equilibrado." (SUPREMO TRIBUNAL FEDERAL. Arguição de Descumprimento de Preceito Fundamental n ${ }^{\circ}$ 101\%/DF. Min. Rel. Carmen Lúcia. Julgado em 24.06.2009, fls. 69-70).

557 “[...] O SENHOR MINISTRO GILMAR MENDES (PRESIDENTE) - Vossa Excelência, Ministra Carmen Lúcia, está excluindo aquelas importações no âmbito do Mercosul?"

A SENHORA MINISTRA CARMEN LÚCIA (RELATORA) - "Sim. Aquelas nem foram impugnadas aqui exatamente porque as relativas ao cumprimento irrecorrível da decisão do Tribunal Arbitral ad hoc não há como desfazer e, aliás, elas estão constando das normas."

O SENHOR MINISTRO MARCO AURÉLIO - "Esse acordo se sobrepõe à Constituição, quanto ao meio ambiente nacional?"

A SENHORA MINISTRA CÁRMEN LÚCIA (RELATORA) - "Não é um acordo; foi uma decisão de um tribunal, e a norma do art. $4^{\circ}$, parágrafo único da Constituição exatamente distingue, diferencia o tratamento a ser dado a estes países do bloco. Tem fundamento constitucional, conforme devidamente comprovado. [...]." (Id., ibid., 2009, fl. 201, grifo nosso).

558 "7. Autorização para importação de remoldados provenientes de Estados integrantes do Mercosul limitados ao produto final, pneu, e não às carcaças: determinação do Tribunal ad hoc, à qual teve de se submeter o Brasil em decorrência dos acordos firmados pelo bloco econômico: ausência de tratamento discriminatório nas relações comerciais firmadas pelo Brasil.” (Id., ibid., 2009, fls. 4-5). 
Sistema de Solução de Controvérsias da OMC, sem, contudo, acatá-lo na sua integralidade, o que afasta a possibilidade de subordinação, também, a essa decisão. Pode-se concluir que, neste caso, a comunicação foi harmoniosa com um e parcialmente harmoniosa (ou dissonante) com o outro.

3.2.2.4 Cooperação com o Tribunal Penal Internacional: Petição 4625/República do Sudão

Em 31 de março de 2005, o Conselho de Segurança da Organização das Nações Unidas aprovou a Resolução 1.593, a qual delegou ao Tribunal Penal Internacional (TPI) a jurisdição para investigar, processar e julgar os indivíduos responsáveis pelos crimes internacionais ocorridos na província de Darfur, República do Sudão ${ }^{559}$. O promotor do TPI iniciou as investigações no mesmo ano e acabou por pedir a prisão de vários líderes sudaneses, inclusive do presidente em exercício do país, Omar Al-Bashir. Em 2009 foi proferido o primeiro mandado de detenção e entrega do presidente ${ }^{560}$ e, em 2010, um segundo mandado foi emitido pelo Tribunal, trazendo novas imputações ${ }^{561}$.

No Brasil, o pedido de cooperação foi encaminhado ao Supremo Tribunal Federal, onde foi recebido como a Petição 4625-1/República do Sudão, em 16 julho de 2009. No dia 30 do mesmo mês, o Ministro Celso Mello, no exercício temporário da presidência do Tribunal, proferiu um despacho no qual analisou de maneira detida vários pontos concernentes, dentre outros temas, à: recepção do Estatuto de Roma do TPI pela ordem constitucional brasileira, à imunidade de jurisdição dos chefes de Estado e à competência do STF para analisar um pedido de entrega ${ }^{562}$.

Em seu despacho, o Ministro Mello constata a existência do dever de cooperação com o TPI e afirma que essa é uma "Alta Corte Judiciária" que pode ser qualificada como um "tribunal revestido de caráter supraestatal" ${ }^{563}$. Reafirma que o próprio Estatuto de Roma, no art. 88, determina aos Estados que instituam no plano interno procedimentos capazes de operacionalizar todas as formas de cooperação com o Tribunal. Menciona, após, a tramitação do Projeto de Lei 4.038/2008 na Câmara dos Deputados, o qual dispõe

\footnotetext{
${ }_{559}^{55}$ UNITED NATIONS. SECURITY COUNCIL. Resolution 1.593 (2005). 5158th meeting, 31 march 2005. ${ }^{560}$ INTERNATIONAL CRIMINAL COURT. PRE-TRIAL CHAMBER I. Warrant of Arrest for Omar Hassan Ahmad Al-Bashir. 4 march 2009.

${ }^{561}$ INTERNATIONAL CRIMINAL COURT. PRE-TRIAL CHAMBER I. Warrant of Arrest for Omar Hassan Ahmad Al-Bashir. 12 july 2010.

${ }^{562}$ SUPREMO TRIBUNAL FEDERAL. Petição 4.625/ República do Sudão. Requerente: Tribunal Penal Internacional (Estatuto de Roma). Requerido: Omar Hassan Ahmad Al Bashir (Presidente do Sudão). Rel. Min. Rosa Webber. Decisão monocrática do Presidente em exercício Min. Celso Mello, publicada em 04.08.2009.

${ }^{563}$ Id., ibid., fls. 5 .
} 
sobre a tipificação dos crimes internacionais constantes no Estatuto e estabelece normas processuais, regulando essa cooperação ${ }^{564}$.

Passa, então, a considerar o art. 27 do Estatuto de Roma, que estabelece a desconsideração da condição da qualidade oficial dos acusados para fins de responsabilidade criminal. Faz menção, ainda que indireta, ao caso relativo ao Mandado de Prisão de 11 de abril de 2000 (República Democrática do Congo v. Bélgica, 2002) pela Corte Internacional de Justiça, ressaltando a sua posição na manutenção da imunidade de jurisdição de certas autoridades perante tribunais estrangeiros. E, logo em seguida, traz o contraponto, usando como argumento a relativização da soberania e a prevalência dos direitos humanos ${ }^{565}$.

Em seguida, o Ministro discorre sobre as questões relativas ao Estatuto de Roma e ao ordenamento jurídico nacional, trazendo as experiências de outros países na superação de problemas parecidos. Termina seu despacho concluindo que o pedido cooperacional de detenção e entrega do presidente Al-Bashir só poderia ser efetivado se esse se encontrasse em território brasileiro, o que não acontecia. Pediu, então, a manifestação da Procuradoria Geral da República sobre as questões ali ventiladas e outras que o MPF achar pertinentes, relativas à obrigação geral de cooperar com o TPI.

Esse caso foi o primeiro pedido de cooperação do Tribunal Penal Internacional que provocou a análise do Poder Judiciário. Trata-se de um claro pedido de cooperação jurídica internacional vertical, uma vez que o TPI determinou aos Estados que detivessem e entregassem o indivíduo à sua jurisdição. Tais pedidos são decisões judiciais internacionais que exigem uma conduta ativa dos Estados e, por isso, o Estatuto determina que esses implementem legislações que facilitem sua efetivação - as enabling legislations. O simples fato do pedido de cooperação do TPI ter levantado essas discussões já dá indícios de que o Poder Judiciário brasileiro caminha para uma comunicação mais informada com o Tribunal Penal Internacional e, quem sabe, futuramente, plenamente harmônica.

\footnotetext{
${ }^{564}$ BRASIL. Projeto de Lei 4.038, de 2008. Dispõe sobre o crime de genocídio, define os crimes contra a humanidade, os crimes de guerra e os crimes contra a administração da justiça do Tribunal Penal Internacional, institui normas processuais específicas, dispõe sobre a cooperação com o Tribunal Penal Internacional, e dá outras providências. Apresentado por meio da Mensagem n. 700, de 17 de setembro de 2008.

${ }^{565}$ SUPREMO TRIBUNAL FEDERAL. Petição 4.625/ República do Sudão. Requerente: Tribunal Penal Internacional (Estatuto de Roma). Requerido: Omar Hassan Ahmad Al Bashir (Presidente do Sudão). Rel. Min. Rosa Webber. Decisão monocrática do Presidente em exercício Min. Celso Mello, publicada em 04.08.2009. fls. 6-8.
} 
3.2.2.5 Lei de Anistia e Crimes da Ditadura Militar: ADPF 153 e Caso Gomes Lund e outros ("Guerrilha do Araguaia")

Em 24 de abril de 2010, o Supremo Tribunal Federal julgou a Arguição de Descumprimento de Preceito Fundamental $n^{\circ} 153$, de autoria do Conselho Federal da Ordem dos Advogados do Brasil, a qual pedia ao STF que interpretasse o parágrafo $1^{\circ}$ do artigo $1^{\circ}$ da Lei 6.683/79 (conhecida como "Lei da Anistia"), conforme a Constituição Federal de 1988. A controvérsia girava em torno da necessidade de esclarecer se os crimes praticados pelos agentes do Estado na época da Ditadura Militar tinham, de fato, sido anistiados na figura de crimes conexos aos crimes políticos, como consta na redação do referido dispositivo ${ }^{566}$.

Simultaneamente ao trâmite da ADPF 153, o caso Gomes Lund e outros vs. Brasil $^{567}$ encontrava-se perante a Corte Interamericana de Direitos Humanos. Nesse, a Comissão Interamericana de Direitos Humanos demandou o Estado brasileiro pela violação de vários dispositivos da Convenção Americana de Direitos Humanos $(\mathrm{CADH})^{568}$, justamente em razão, dentre outros fatos, da existência da Lei de Anistia que, ao impor obstáculos à persecução criminal dos responsáveis por torturas, desaparecimentos forçados e outros crimes, não permitia o acesso à justiça das vítimas ${ }^{569}$.

Por sete votos a dois, o Supremo Tribunal Federal declarou improcedente a ADPF 153, concluindo que a interpretação que inclui os crimes praticados por agentes do Estado como conexos aos políticos, de acordo com o parágrafo $1^{\circ}$ do artigo $1^{\circ}$ da Lei de Anistia brasileira, foi recebida pela ordem constitucional de 1988 e, portanto, continua plenamente válida de modo a impedir a persecução penal desses indivíduos ${ }^{570}$. Do outro lado, exatos

\footnotetext{
566 SUPREMO TRIBUNAL FEDERAL. Arguição de Descumprimento de Preceito Fundamental $\mathbf{n}^{\circ}$ 153/DF. Min. Rel. Eros Grau. Julgado em 24.04.2010. fls. 5-10 passim.

${ }^{567}$ CORTE INTERAMERICANA DE DIREITOS HUMANOS. Caso Gomes Lund e outros ("Guerrilha do Araguaia") vs. Brasil. Exceções preliminares, mérito, reparações e custas. Sentença de 24 de novembro de 2010. Série C, $\mathrm{n}^{\circ} 219$.

${ }^{568}$ Arts. $3^{\circ}$ (direito ao reconhecimento da personalidade jurídica), $4^{\circ}$ (direito à vida), $5^{\circ}$ (direito à integridade pessoal), $7^{\circ}$ (direito à liberdade pessoal), $8^{\circ}$ (garantias judiciais), 13 (liberdade de pensamento e expressão) e 25 (proteção judicial), da Convenção Americana sobre Direitos Humanos, em conexão com as obrigações previstas nos arts. 1.1 (obrigação geral de respeito e garantia dos direitos humanos) e $2^{\circ}$ (dever de adotar disposições de direito interno).

${ }^{569}$ CORTE INTERAMERICANA DE DIREITOS HUMANOS. Op. cit., 2010, p. 66.

570 “3. Conceito e definição de "crime político" pela Lei n. 6.683/79. São crimes conexos aos crimes políticos "os crimes de qualquer natureza relacionados com os crimes políticos ou praticados por motivação política"; podem ser de "qualquer natureza", mas [i] hão de terem estado relacionados com os crimes políticos ou [ii] hão de terem sido praticados por motivação política; são crimes outros que não políticos; são crimes comuns, porém [i] relacionados com os crimes políticos ou [ii] praticados por motivação política. A expressão crimes conexos a crimes políticos conota sentido a ser sindicado no momento histórico da sanção da lei. A chamada Lei de anistia diz com uma conexão sui generis, própria ao momento histórico da transição para a democracia. Ignora, no contexto da Lei n. 6.683/79, o sentido ou os sentidos correntes, na doutrina, da
} 
sete meses depois, em 24 de novembro de 2010, a Corte Interamericana de Direitos Humanos condenou o Brasil no caso Gomes Lund e outros e declarou ser a referida lei inválida, logo, incapaz de surtir efeitos, pois viola a $\mathrm{CADH}^{571}$.

A partir daí formou-se uma situação inédita, pois, pela primeira vez, uma decisão judicial internacional colidiu frontalmente com uma decisão do Supremo Tribunal Federal. O caso, no entanto, é importante, porque expõe as principais causas de dissonância na comunicação entre os tribunais internacionais e o Poder Judiciário brasileiro. A primeira foi, certamente, a desconsideração pelo STF dos tratados internacionais de direitos humanos de que o Brasil é parte e, consequentemente, da jurisprudência internacional a respeito da matéria, o que fez com que não interpretasse o direito pátrio de maneira consistente com suas obrigações internacionais, causando a condenação do Estado. A segunda, depois de proferida a sentença internacional, foi a recusa, até o momento ${ }^{572}$, de cooperar com a Corte Interamericana de Direitos Humanos sob argumentos de seus membros, veiculados na imprensa, de que "a decisão é política e não vincula o Brasil” ou de que essa "só vale para o plano internacional"

A não realização de uma interpretação consistente do direito brasileiro com suas obrigações internacionais e a falta do diálogo das cortes é evidente no acórdão da ADPF $153^{574}$. Quatro ministros - Eros Grau, Celso Mello, Cezar Peluso e Ricardo Lewandowski - mencionaram, ainda que de maneira generalista, os tratados de direitos humanos dos quais o Brasil é parte. Desses, apenas dois - Celso Mello e Ricardo Lewandowski -

chamada conexão criminal; refere o que "se procurou", segundo a inicial, vale dizer, estender a anistia criminal de natureza política aos agentes do Estado encarregados da repressão." (SUPREMO TRIBUNAL FEDERAL. Arguição de Descumprimento de Preceito Fundamental n 153/DF. Min. Rel. Eros Grau. Julgado em 24.04.2010. fl. 2).

571 "Dada sua manifesta incompatibilidade com a Convenção Americana, as disposições da Lei de Anistia brasileira que impedem a investigação e sanção de graves violações de direitos humanos carecem de efeitos jurídicos. Em consequência, não podem continuar a representar um obstáculo para a investigação dos fatos do presente caso, nem para a identificação e punição dos responsáveis, nem podem ter igual ou similar impacto sobre outros casos de graves violações de direitos humanos consagrados na Convenção Americana ocorridos no Brasil." (CORTE INTERAMERICANA DE DIREITOS HUMANOS. Caso Gomes Lund e outros ("Guerrilha do Araguaia") vs. Brasil. Exceções preliminares, mérito, reparações e custas. Sentença de 24 de novembro de 2010. Série C, n²19. p. 65).

572 Ainda estão pendentes embargos de declaração interpostos pelo Conselho Federal da OAB a fim de que o STF considere a sentença da Corte Interamericana de Direitos Humanos.

${ }^{573}$ RECONDO, Felipe; ARRUDA, Roldão. Decisão da OEA abre debate sobre STF. Jornal O Estado de São Paulo. Disponível em: <http://www.estadao.com.br/noticias/nacional,decisao-da-oea-abre-debate-sobrestf,654133,0.htm>. Acesso em: 30 dez. 2013.

${ }^{574}$ Vide: RAMOS, André de Carvalho. Crimes da ditadura militar: a ADPF 153 e a Corte Interamericana de Direitos Humanos. In: GOMES, Luis Flávio; MAZZUOLI, Valério de Oliveira. Crimes da ditadura militar. Uma análise à luz da jurisprudência atual da Corte Interamericana de Direitos Humanos: Argentina, Brasil, Chile e Uruguai. São Paulo: Editora Revista dos Tribunais, 2011. pp. 174-225. 
citaram a jurisprudência da Corte Interamericana de Direitos Humanos, entretanto, não realizaram um verdadeiro diálogo com a mesma ${ }^{575}$.

Por fim, os argumentos de que a sentença da Corte Interamericana de Direitos Humanos não vale para o plano interno, ou que essa tem natureza meramente política, refletem as principais causas de dissonância na comunicação entre tribunais internos e internacionais: a adoção, equivocada, do paradigma do dualismo como meio de repelir a aplicação da decisão internacional na ordem interna e a falta do reconhecimento do tribunal internacional como um ente judiciário com jurisdição sob o Estado brasileiro ${ }^{576}$. Obviamente que tais objeções não se sustentam e, reflexo disso é que instituições públicas brasileiras, como o Ministério Público Federal ${ }^{577}$, a Ordem dos Advogados do Brasil ${ }^{578}$, entre outras, continuam envidando esforços para a implementação da decisão do caso Gomes Lund e outros - apesar da contrária decisão erga omnes e vinculante do Supremo na ADPF 153.

A plena efetivação das decisões judiciais internacionais emanadas pela Corte Interamericana de Direitos Humanos exige a combinação dos mecanismos de comunicação do diálogo das cortes e da cooperação jurídica internacional vertical. Esse segundo só será

\footnotetext{
575 "No presente caso, o Tribunal observa que não foi exercido o controle de convencionalidade pelas autoridades jurisdicionais do Estado e que, pelo contrário, a decisão do Supremo Tribunal Federal confirmou a validade da interpretação da Lei de Anistia, sem considerar as obrigações internacionais do Brasil derivadas do Direito Internacional, particularmente aquelas estabelecidas nos artigos 8 e 25 da Convenção Americana, em relação com os artigos 1.1 e 2 do mesmo instrumento. O Tribunal estima oportuno recordar que a obrigação de cumprir as obrigações internacionais voluntariamente contraídas corresponde a um princípio básico do direito sobre a responsabilidade internacional dos Estados, respaldado pela jurisprudência internacional e nacional, segundo o qual aqueles devem acatar suas obrigações convencionais internacionais de boa-fé (pacta sunt servanda). Como já salientou esta Corte e conforme dispõe o artigo 27 da Convenção de Viena sobre o Direito dos Tratados de 1969, os Estados não podem, por razões de ordem interna, descumprir obrigações internacionais. As obrigações convencionais dos Estados-Parte vinculam todos sus poderes e órgãos, os quais devem garantir o cumprimento das disposições convencionais e seus efeitos próprios (effet utile) no plano de seu direito interno." (CORTE INTERAMERICANA DE DIREITOS HUMANOS. Caso Gomes Lund e outros ("Guerrilha do Araguaia") vs. Brasil. Exceções preliminares, mérito, reparações e custas. Sentença de 24 de novembro de 2010. Série C, n 219. p. 66).

${ }_{577}^{577}$ Vide tópico 1.2, supra.

577 "Em razão do caráter vinculante da decisão da Corte Interamericana de Direitos Humanos no caso Gomes Lund, há necessidade de dar-lhe cumprimento na parte que cabe ao Ministério Público Federal, notadamente em relação aos pontos resolutivos 3 e 9 da sentença, que tratam da obrigatoriedade da persecução penal de graves violações de direitos humanos, a fim de elucidá-las e determinar as correspondentes responsabilidades criminais." (MINISTÉRIO PÚBLICO FEDERAL. PROCURADORIA GERAL DA REPÚBLICA. I Workshop Internacional sobre Justiça de Transição: os efeitos domésticos da decisão da Corte Interamericana de Direitos Humanos no Caso Gomes Lund e outros vs. Brasil e as atribuições do Ministério Público Federal. $2^{\mathrm{a}}$ Câmara de Coordenação e Revisão, Documento n²/2011, 3 de outubro de 2011. p. 7).

${ }^{578}$ Segundo o Conselho Federal da Ordem dos Advogados do Brasil na petição de embargos de declaração na ADPF 153: "Em outras palavras, assentado por esta Eg. Corte que a anistia concedida pelo diploma legislativo em tela teve caráter bilateral, em tese, está se afirmando que o Estado brasileiro não se encontra submetido à competência da Corte Interamericana de Direitos Humanos, esquecendo-se, no particular, que quem define competência é quem a tem." (SUPREMO TRIBUNAL FEDERAL. Arguição de Descumprimento de Preceito Fundamental n 153/DF. Min. Rel. Eros Grau. Julgado em 24.04.2010).
} 
de fato operacionalizado no Brasil quando aprovada uma legislação capaz de organizar e impulsionar a implementação dessas decisões em sua totalidade, abrangendo toda a esfera estatal. Está em trâmite no Senado Federal o Projeto de Lei n. 4.667/2004 ${ }^{579}$, o qual pretende cumprir esse papel. Para colocá-lo em prática, contudo, da maneira correta, ainda são necessárias alterações, sob o risco de não servir ao propósito a que se destina ${ }^{580}$.

O conflito entre a ADPF 153 e a sentença do Caso Gomes Lund e outros da Corte Interamericana de Direitos Humanos é ilustrativo das tensões típicas das relações entre tribunais internacionais e internos. A controvérsia, no entanto, está sendo de certa maneira saudável, pois promove importante debate no meio jurídico e, também, na sociedade, sobre o papel e a importância da Corte Interamericana de Direitos Humanos no Brasil. Nem tudo, porém, está perdido, pois, neste ano, o Supremo deve julgar os Embargos de Declaração interpostos pela $\mathrm{OAB}$ e, com a nova composição do Tribunal, será possível um novo entendimento rumo a uma comunicação harmônica.

3.2.2.6 Opiniões Consultivas do Tribunal Permanente de Revisão do Mercosul e a Emenda Regimental $n^{\circ} 48$, de 3 de abril de 2012, do STF: aproximação institucional como um caminho para o diálogo e a cooperação

Em 3 de abril de 2012, o Supremo Tribunal Federal aprovou a Emenda Regimental $\mathrm{n}^{\circ} 48$, a qual instituiu procedimento para o encaminhamento de pedidos de opiniões consultivas ao Tribunal Permanente de Revisão do Mercosul. Trata-se de um importante instrumento para promover a harmonização das normas mercosulinas em todos os países do bloco, centrado no Tribunal Internacional Permanente criado pelo Protocolo de Olivos, em $2002^{581}$.

A Emenda Regimental prevê que a requisição deve se originar de processo judicial em curso no Poder Judiciário brasileiro, devendo se fundar em questões sobre a vigência ou interpretação das normas desse bloco regional, incluindo decisões do Conselho do

\footnotetext{
579 BRASIL. Projeto de Lei 4.667, de 2004. Dispõe sobre os efeitos jurídicos das decisões dos Organismos Internacionais de Proteção aos Direitos Humanos e dá outras providências. Apresentado em 15 de dezembro de 2004.

580 Vide: MINISTÉRIO PÚBLICO FEDERAL. Nota Técnica ao Projeto de Lei ${ }^{\circ}$ 4.667, de 2004. Elaborada pelos Procuradores Regionais da República André de Carvalho Ramos, Denise Neves Abade, Geisa de Assis Rodrigues e Robério Nunes dos Anjos Filho. 3 de agosto de 2010; MAEOKA, Erika. Os comentários ao Projeto de Lei 4.667, de 2004, e os Limites à Eficácia Interna das Sentenças Internacionais. In: MENEZES, Wagner. Direito Internacional em Expansão. Belo Horizonte: Arraes, 2012, v. 1. pp. 365-76.

581 “[...] Há que se verificar, no entanto, que tais manifestações constituem prius logico elaborado por juristas pluranacionais, indicados pelo livre querer das partes, de especial relevância em matérias carentes de interpretação ou de harmonização hermenêutica." (FONTOURA, Jorge. STF fortacele Tribunal Permanente de Revisão do Mercosul. Jornal Gazeta do Povo. $1^{\circ}$ de junho de 2012).
} 
Mercado Comum, resoluções do Grupo Mercado Comum e diretrizes da Comissão de Comércio do Mercosul. Ao receber a solicitação, o presidente do Supremo Tribunal Federal fará um breve juízo de admissibilidade e a sujeitará à votação virtual dos demais ministros. Se aprovada, o STF a encaminhará para o TPR, com cópias para a Secretaria do Mercosul e para as demais cortes supremas dos países do bloco ${ }^{582}$.

A aproximação institucional entre tribunais internacionais e internos é fundamental para a plena comunicação entre as partes. A ER nº 48 é um importante passo nessa direção, pois promove o conhecimento mútuo que leva ao diálogo e à cooperação jurídica internacional vertical. Recentemente, a realização de uma sessão da Corte Interamericana de Direitos Humanos em Brasília serviu, também, como um esforço de aproximação entre os dois órgãos judiciais. Tais medidas devem ser estimuladas, pois seus resultados servirão a um só propósito: à realização da justiça e do Império do Direito, tanto no plano interno quanto no internacional.

${ }^{582}$ SUPREMO TRIBUNAL FEDERAL. Emenda Regimental $\mathbf{n}^{\circ}$ 48. Aprovada em 3 de abril de 2012, passim. 


\section{CONCLUSÃO}

A ascensão dos tribunais internacionais é, certamente, uma das principais evoluções que marcaram o Direito Internacional Contemporâneo. $\mathrm{O}$ estabelecimento desses órgãos judiciais internacionais foi imprescindível para uma mudança da função do Direito na comunidade internacional. Se antes, no período clássico, o Direito Internacional Público era desprovido de juridicidade, na medida em que tributava sua validade e eficácia aos Estados, hoje esses se encontram sob seu império, devendo seguir seus preceitos e adequar-se a eles.

Da mesma forma, a expansão do Direito Internacional também possibilitou uma maior atuação dos órgãos estatais na esfera normativa internacional. Atualmente, os tribunais domésticos decidem casos que possuem elementos de internacionalidade, como a aplicação de um tratado ou de uma decisão judicial internacional. Trata-se de um desdobramento funcional do juiz interno, promovido por sua série de fatores nacionais e internacionais, que tiveram por consequência a tomada de consciência de que o Direito é uma construção universal.

Essa atividade, contudo, não pode ser solta, deve seguir os preceitos estabelecidos pelos órgãos internacionais competentes: os políticos e, principalmente, os judiciais. Se assim não for realizada, corre-se o risco de se fazer do Direito Internacional uma quimera jurídica, cujas faces mudam de Estado para Estado, de Organização Internacional para Organização Internacional, legando à comunidade internacional o caos normativo e, consequentemente, a verdadeira anarquia. Resulta daí, a importância da devida observação e execução das decisões judiciais internacionais, uma vez que elas são os canais pelos quais os tribunais internacionais exercem sua jurisdição, resolvendo as controvérsias e desenvolvendo o Direito.

Diante dessa realidade, o direito brasileiro, lastreado na Constituição Federal de 1988, possibilita uma abertura - ainda que tímida - a normativa internacional, cristalizada em vários dispositivos do texto constitucional. Mesmo tendo a $\mathrm{CF}$ sido elaborada numa época em que o Brasil era parte de apenas dois tribunais internacionais, uma interpretação sistêmica de suas normas permite a aplicação de mecanismos para promover a comunicação daqueles com o Poder Judiciário. Tais mecanismos funcionam como canais pelos quais a relação entre as jurisdições seja harmoniosa e positiva, levando a uma convergência de atuações e ao resguardo do rule of law no plano internacional. Não 
obstante, os tribunais superiores, em especial o Supremo Tribunal Federal, quando deparados com questões que envolvem tribunais internacionais, não tem refletido esse entendimento normativo.

No contexto dessas afirmações, com o objetivo de buscar os fundamentos do fenômeno, o primeiro capítulo apresentou o histórico e o desenvolvimento da jurisdicionalização do Direito Internacional e como isso possibilitou o estabelecimento de tribunais internacionais dotados de poder jurisdicional internacional, esse com faces do império e da jurisdictio, o que torna tais órgãos competentes para resolver definitivamente, por meio de decisões obrigatórias, as controvérsias a eles submetidas e, ainda, desenvolver o DIP. Essa evolução trouxe mudanças significativas nos planos normativo e institucional da sociedade internacional. As decisões judiciais internacionais, formadoras da jurisprudência internacional, passaram a ocupar um lugar de protagonismo no rol das fontes, alterando a relação do direito internacional com os direitos internos, agora mais fluída e não mais pautada pelos paradigmas do monismo e do dualismo.

No segundo capítulo houve aprofundamento analítico das decisões judiciais internacionais, tendo recorte àquelas que produzem efeitos externos, ou seja, sentenças, medidas cautelares, opiniões consultivas e outras. Essas têm em comum o fato de representarem as faces da jurisdição internacional, sendo as obrigatórias frutos do império e as opiniões consultivas frutos da jurisdictio. O pleno cumprimento dessas decisões é um dever jurídico, derivado de sua obrigatoriedade, da boa fé e do valor do Império do Direito. O controle de suas observância e execução é fruto de um esforço dos próprios tribunais, das organizações internacionais e também dos tribunais domésticos. Ao realizar esse objetivo, todos esses órgãos cooperam no sentido de reforçar o rule of Law no plano internacional.

O terceiro capítulo demonstrou a importância dos Poderes Judiciários nacionais na sociedade internacional como um dos traços característico do Direito Internacional Contemporâneo, atuando na sua aplicação e também no seu desenvolvimento. Nesse contexto, tribunais internacionais e tribunais domésticos se comunicam por intermédio de mecanismos - aqui estudados a cortesia judicial, a subordinação, o diálogo das cortes e a cooperação jurídica internacional vertical - para que se efetivem as decisões dos primeiros. Essa comunicação, no entanto, nem sempre se dá de forma harmônica, muito embora as dissonâncias verificadas tenham, em sua maioria, origem política, e não jurídica.

Ainda no terceiro capítulo, foi observado que, no Brasil, a ordem constitucional de 1988 permite e promove, norteada pelos princípios elencados no artigo $4^{\circ}$ da $\mathrm{CF}$, a 
abertura do Direito Brasileiro ao Direito Internacional. As plenas observância e execução dessas devem, no entanto, ser fiscalizadas e, quando necessário, promovidas pelo Poder Judiciário Brasileiro. Nessa função, alguns obstáculos podem surgir, contudo foi estudado que sua superação é juridicamente possível. No final, casos concretos em que o STF foi colocado diante de decisões judiciais internacionais foram analisados e os mecanismos de comunicação utilizados e sua eficácia foram auferidos.

Demonstrou-se que a evolução da autotutela da guerra, no DIP clássico, para o estabelecimento de tribunais internacionais, no Contemporâneo, deu-se pela edificação do princípio da solução pacífica de controvérsias, que encontrou no mundo Pós-Segunda Guerra Mundial o ambiente adequado para atingir seu ideal. A jurisdicionalização do Direito Internacional foi uma consequência disso, respondendo às demandas da sociedade internacional contemporânea por mecanismos mais estáveis e seguros para resolver seus conflitos.

A atuação desses tribunais internacionais se legitima no seu poder jurisdicional, conferido pelos sujeitos de DIP a esses órgãos para resolver definitivamente suas controvérsias através decisões obrigatórias, e para desenvolver o Direito. O reflexo dessa evolução no plano normativo do DIP contemporâneo é a crescente importância da jurisprudência internacional no rol das fontes. Isso, consequentemente, reflete na interação com os direitos internos, na medida em que aumenta a complexidade na definição das relações de coordenação e subordinação, fazendo com que não seja mais possível adotar paradigmas estanques para regrar as relações com o DIP, como, por exemplo, monismo e dualismo.

As decisões judiciais internacionais analisadas no presente trabalho foram aquelas que surtem efeitos externos à relação processual formal, sendo essas: as sentenças, as medidas cautelares, as opiniões consultivas, a decisão de Pronta Libertação de Navios e Tripulações do Tribunal Internacional para o Direito do Mar e os pedidos cooperacionais do Tribunal Penal Internacional. Tais decisões são frutos da jurisdição internacional e, portanto, devem ser observadas e cumpridas com fundamento jurídico na boa fé e no valor do rule of Law. O controle disso é promovido pelos tribunais internacionais, pelas organizações internacionais e pelos Poderes Judiciários internos.

Esses últimos adquiriram relevância nas relações exteriores dos Estados na medida em que o Direito Internacional passou a regular, diretamente, questões que afetam os direitos internos. Assim, os juízes nacionais passaram a interpretar e aplicar, também, o Direito Internacional, realizando uma interpretação consistente dos direitos domésticos 
com as obrigações internacionais do Estado. Aqui incluí-se a plena efetivação das decisões judiciais internacionais e, para cumprir essa missão, utilizam-se os mecanismos de comunicação analisados, adotados de acordo com a cultura jurídica de cada país e do status que a normativa internacional possui na ordem jurídica interna de cada um.

O Poder Judiciário brasileiro, em especial o STF, vem realizando essa comunicação, ainda que limitadamente, por intermédio, principalmente, dos mecanismos do diálogo das cortes e da cooperação jurídica internacional vertical. $\mathrm{O}$ estudo dos casos permitiu a constatação de que o diálogo é aplicado de forma unilateral e seletiva. Já a cooperação o é de forma extremamente precária, devendo ser reforçada com a adoção de legislações (enabling legislations) que coadunam com a atividade dos tribunais internacionais e sirvam de lubrificantes para a plena observância e execução das decisões judiciais internacionais. Nessa esteira, a aproximação institucional também pode ser um caminho para uma comunicação harmoniosa.

A aplicação, pelos tribunais brasileiros, de dogmas soberanistas anacrônicos como escusas para não cumprir com obrigações internacionais, dentre as quais a efetivação de decisões judiciais internacionais, resulta num ciclo vicioso. Por não observar a normativa internacional, o Estado comete um ato ilícito internacional e é responsabilizado por um tribunal internacional, que profere contra ele uma decisão judicial internacional que não será cumprida, o que levará a outro ilícito e assim por diante.

Muitos avanços são perceptíveis. No entanto, ainda há muito que ser feito. A adoção de legislações que facilitem a comunicação harmoniosa entre os tribunais brasileiros e os internacionais é uma medida adequada, mas será plenamente efetiva se houver a promoção do debate acadêmico sobre tribunais internacionais nas faculdades de Direito e na formação dos quadros do Judiciário e do Ministério Público. Somente assim, será criado um ambiente no qual o reconhecimento mútuo é possível, gerando a consciência de que tribunais internos e internacionais cumprem a mesma função e são norteados pelos mesmos valores, devendo, pois, agir em conjunto.

O Direito brasileiro sempre primou por acompanhar os debates de vanguarda no mundo jurídico e tem agora um grande desafio no contexto da globalidade: refletir o processo de jurisdicionalização com uma nova perspectiva, a da efetivação das decisões dos tribunais internacionais. Esse desafio vai envolver a renovação de concepções da forma de se pensar o lugar do direito internacional e sua relação com o direito interno e do papel dos tribunais que, crescentemente, ditam, refletem e preservam o direito dos povos, dos indivíduos. 


\section{REFERÊNCIAS}

ABADE, Denise Neves. Direitos fundamentais na cooperação jurídica internacional: extradição, assistência jurídica, execução de sentença estrangeira e transferência de presos. São Paulo: Saraiva, 2013.

ABI-SAAB, Georges. Fragmentation or unification: some concluding remarks. Journal of International Law and Politics. New York University, 1999, v. 31. pp. 919-33.

ACCIOLY, Hildebrando. Tratado de Direito Internacional Público. São Paulo: Quartier Latin, 2009, v. III.

; NASCIMENTO E SILVA, G. E.; CASELlA, Paulo Borba. Manual de Direito Internacional Público. 17. ed. São Paulo: Saraiva, 2009.

ALJAGHOUB, Mahasen. The Advisory Function of International Court of Justice 1946-2005. Berlin-Heidelberg-New York: Springer, 2006.

ALVIM NETTO, José Manuel de Arruda. Direito Processual Civil: teoria geral do processo de conhecimento. São Paulo: Revista dos Tribunais, 1972. p. 66.

AMARAL JUNIOR, Alberto do. Curso de Direito Internacional Público. 2. ed. São Paulo: Atlas, 2011.

ARANGIO-RUIZ, Gaetano. The normative role of the General Assembly of the United Nations and the Declaration of Principles of Friendly Relations. With an appendix on the Concept of International Law and the Theory of International Organizations. RCADI, 1972-III, v. 137. pp. 419-742).

Le domaine réservé: l'organisation internationale et le rapport entre droit international et droit interne: cours général de droit international public. RCADI, 1990, t. 225. pp. 9-484.

ARAÚJO, Nadia. A influência das Opiniões Consultivas da Corte Interamericana de Direitos Humanos no Ordenamento Jurídico Brasileiro. Revista CEJ. Brasília, n 29 , abr./jun. 2005. pp. 64-9.

ARNAUD, André-Jean. O direito entre modernidade e globalização: lições de filosofia. Tradução de Patrice Charles Wuillaume. Rio de Janeiro: Renovar, 1999.

ASCENSIO, Hervé. La notion de Jurisdiction Internationale en Question. In: SOCIETÉ FRANÇAISE POUR LE DROIT INTERNATIONAL. La Jurisdictionnalisation du Droit International. Colloque de Lille. Paris: Pedone, 2003. pp. 163-202.

BARBERIS, Julio A. Formación del derecho internacional. Buenos Aires: Ábaco de Rodolfo Depalma, 1994.

BARILE, Giuseppe. Sulla competenza della Corte Internazionale di Giustizia ad indicare misure cautelari. Rivista di Diritto Internazionale, 1958, v. XLI. pp. 111-22. 
BARRETO, Irineu Cabral. A Convenção Europeia dos Direitos do Homem Anotada. 3. ed. rev. e actualizada. Coimbra: Coimbra Editora, 2005.

BARROSO, Luis Roberto. Curso de Direito Constitucional Contemporâneo: os conceitos fundamentais e a construção do novo modelo. 4. ed. São Paulo: Saraiva, 2013.

BEDERMAN, David J. International Law in Antiquity. Cambridge: Cambridge University Press, 2001.

BEDJAOUI, Mohamed. The reception by National Courts of Decisions of International Tribunals. New York University Journal of International Law and Politics, 1995-1996, v. 28. pp. 45-64.

BENVENISTI, Eyal. The conception of International Law as a Legal System. Tel Aviv University Law School: Tel Aviv University Law Faculty Papers, 2008. Paper 83.

; DOWNS, George W. Court Cooperation, Executive Accountability, and Global Governance. New York University Journal of International Law and Politics, 2009, v. 41, n. 4. pp. 931-58.

BERGERÈS, Maurice-Christian. Contentieux communautaire. Paris: P.U.F., 1989.

BERGSMO, Morten. O Regime Jurisdicional da Corte Internacional Criminal. In: CHOUKR, Fauzi Hassan; AMBOS, Kai (Orgs.). Tribunal Penal Internacional. São Paulo: Revista dos Tribunais, 2000.

BERLIA, Georges. Jurisprudence des tribunaux internationaux en ce qui concerne leur compétence. RCADI, 1955-II, t. 88. pp. 105-57.

BOBBIO, Norberto. Des critères pour résoudre les antinomies. Dialectica, 1964, v. 18, n. 1/4. pp. 237-58.

Teoria do ordenamento jurídico. Tradução de Ari Marcelo Solon, prefácio de Celso Lafer, apresentação de Tércio Sampaio Ferraz Júnior. São Paulo: EDIPRO, 2011.

BRASIL. Constituição da República Federativa do Brasil de 1988. 25. ed. São Paulo: Revista dos Tribunais, 2005.

Projeto de Lei 4.038, de 2008. Dispõe sobre o crime de genocídio, define os crimes contra a humanidade, os crimes de guerra e os crimes contra a administração da justiça do Tribunal Penal Internacional, institui normas processuais específicas, dispõe sobre a cooperação com o Tribunal Penal Internacional, e dá outras providências. Apresentado por meio da Mensagem n. 700, de 17 de setembro de 2008.

Projeto de Lei 4.667, de 2004. Dispõe sobre os efeitos jurídicos das decisões dos Organismos Internacionais de Proteção aos Direitos Humanos e dá outras providências. Apresentado em 15 de dezembro de 2004.

BRIERLY, J. L. Direito Internacional. Tradução de M. R. Crucho de Almeida. 4. ed. Lisba: Fundação Calouste Gulbenkian, 1979. 
BRIGGS, Herbert W. Reservations to the acceptance of compulsory jurisdiction of the International Court of Justice. RCADI, 1958-I, t. 93. pp. 223-367.

BROWN, Chester. The cross-fertilization of principles relating to procedure and remedies in the Jurisprudence of International Courts and Tribunals. Loyola of Los Angeles International and Comparative Law Review, 2008, v. 30. pp. 219-45.

BUERGENTHAL, Thomas. Medidas Provisórias na Corte Interamericana de Direitos Humanos. Boletim da Sociedade Brasileira de Direito Internacional. Ano XLV-XLVI, Dezembro 1992/Maio 1993, nº 84/86. pp. 11-36.

BUSTAMANTE Y SIRVEN, Antonio S. La Seconde Conférence de la Paix. Traduit de L’Espagnol par Georges Scelle. Paris: Sirey, 1909.

CALOYANNI, Mégalos A. L'Organization de la Cour Permanente de Justice International et son Avenir. RCADI, 1931-IV, v. 38. pp. 651-786. p. 664-5.

CANÇADO TRINDADE, Antonio Augusto. Princípios do Direito Internacional Contemporâneo. Brasília: Ed. da UnB, 1981.

O esgotamento dos recursos internos. 2. ed. Brasília: Ed. da UNB, 1997.

Tratado de Direito Internacional dos Direitos Humanos. Porto Alegre: Sergio Antonio Fabris, 1997, v. I.

O Direito Internacional em um mundo em transformação. Rio de Janeiro: Renovar, 2002.

Direitos humanos: personalidade e capacidade Jurídica Internacional do Indivíduo. In: BRANT, Leonardo Nemer Caldeira (coord.). O Brasil e os novos desafios do Direito Internacional. Rio de Janeiro: Forense, 2004. pp. 199-263.

International Law for Humankind: Towards a New Jus Gentium (I). General Course on Public International Law. RCADI, 2005, v. 316. pp. 1-439.

International Law for Humankind: Towards a New Jus Gentium (II). General Course on Public International Law. RCADI, 2005, v. 315. pp. 9-312.

A humanização do Direito Internacional. Belo Horizonte: Del Rey, 2006.

El ejercicio de la Función Judicial Internacional. Memorias de la Corte Interamericana de Derechos Humanos. Belo Horizonte: Del Rey, 2011.

Direito das organizações internacionais. 5. ed. rev., atual. e ampliada. Belo Horizonte: Del Rey, 2012. 838 p.

CANotilho, J.J. Gomes. Direito Constitucional e Teoria da Constituição. 7. ed. 9. reimpr. Coimbra: Almedina, 2003. 
CARNELUTTI, Francesco. Sistema di Diritto Processuale Civile. I Funzione e Composizione del Processo. Padova: Casa Editrice Dott. Antonio Milani, 1936.

CASELLA, Paulo Borba. Fundamentos do Direito Internacional Pós-moderno. São Paulo: Quartier Latin, 2008.

. Direito Internacional no Tempo Antigo. São Paulo: Atlas, 2012a.

Atlas, 2012b.

Direito Internacional no Tempo Medieval e Moderno até Vitória. São Paulo:

. Secessão no Direito Internacional e o Parecer Consultivo da Corte Internacional de Justiça sobre o Kosovo de 22 de julho de 2010. Boletim da Sociedade Brasileira de Direito Internacional. Ano XCVIII, ago/dez. 2013, v. 1, n. 119-24. pp. 111-26.

CASSESE, Antonio. Modern constitutions and international law. RCADI, 1985-III, t. 192. pp. 331-476.

(Ed.). Remarks on Scelle's Theory of Role Splitting (dedoublement fonctionnel) in International Law. European Journal of International Law, 1990, v. 1, n. 1. pp. 210-31.

(Ed.). The Oxford Companion to International Criminal Justice. New York: Oxford University Press, 2009.

CASTBERG, Frede. L'excès de pouvoir dans la justice internationale. RCADI, 1931-I, t. 35. pp. 353-472.

CHANDRASEKHARA, P. Rao ; GAUTIER, Ph. (Eds.). The rules of the International Tribunal for the Law of the Sea: a commentary. Leiden/Boston: Martinus Nijhoff Publishers, 2006.

CHARNEY, Jonathan I. Is international law threatened by multiple international tribunals? RCADI, 1998, t. 271. pp.101-382.

CHARPENTIER, Jean. Le contrôle par les organisations internationales de l'exécution des obligations des états. RCADI, 1983-IV, t. 182. pp.143-245.

CHAZOURNES, Laurence Boisson de. Les ordonnances en indication de mesures conservatoires dans l'Affaire relative à L'Application de la Convention Pour la Prévention et la Repression du Crime de Génocide. Annuaire Français de Droit International, 1993, v. XXXIX. pp. 514-39.

CHIOVENDA, Giuseppe. Instituições de Direito Processual Civil. Relação processual ordinária de cognição (continuação). 2. ed. Trad. J. Guimarães Menegale. São Paulo: Saraiva, 1965, v. III. p. 197.

CIAMPI, Annalisa. The obligation to cooperate. In: CASSESE, Antonio; GAETA, Paola; JONES, John R. W. D. (Eds.). The Rome Statute of the International Criminal Court: a commentary. New York: Oxford University Press, 2009, v. II. pp. 1607-38. 
CINTRA, Antonio Carlos de Araujo; GRINOVER, Ada Pellegrini; DINAMARCO, Cândido Rangel. Teoria geral do processo. 23. ed. São Paulo: Malheiros, 2007.

COLLINS, Lawrence. Provisional and protective measures in international litigation RCADI, 1992-III, t. 234. pp. 9-238.

COMBACAU, Jean; SUR, Serge. Droit International Public. 2. ed. Paris: Montchrestien, 1995.

CONDORELLI, Luigi. L'Autorite de la Decision des Juridictions Internationales Permanentes. In: SOCIETÉ FRANÇAISE DE POUR LE DROIT INTERNATIONAL. Juridiction Internationale Permanente. Colloque de Lyon. Paris: Pedone, 1987. pp. 277313.

CONFORTI, Benedetto. Qualche riflessione sul contributo dei giudici internazionali ed interni al diritto internazionale. In: VENTURINI, Gabriella; BARIATTI, Stefania (Eds.). Diritto Individuali e Giustizia Internazionale. Liber Fausto Pocar. Milano: Giuffrè Editore, 2009. pp. 217-21.

CORTE INTERAMERICANA DE DIREITOS HUMANOS. A Coligação Obrigatória de Jornalistas (Artigos 13 e 29 da Convenção Americana sobre Direitos Humanos). Opinião Consultiva OC-5/85 de 13 de novembro de 1985. Série A, n 5.

Compatibilidade de um Projeto de Lei com o Artigo 8.2.h. da Convenção Americana sobre Direitos Humanos. Opinião Consultiva OC-12/91 de 6 de dezembro de 1991. Série A, $n^{\circ} 12$.

Responsabilidade Internacional por Expedição e Aplicação de Leis Violadoras da Convenção (Arts. 1 e 2 Convenção Americana sobre Direitos Humanos). Opinião Consultiva OC-14/94 de 9 de dezembro de 1994. Série A, n 14.

O Direito à Informação sobre Assistência Consular no Marco das Garantias do Devido Processo Legal. Opinião Consultiva OC-16/99, de $1^{\circ}$ de outubro de 1999. Série A, $\mathrm{n}^{\circ} 16$.

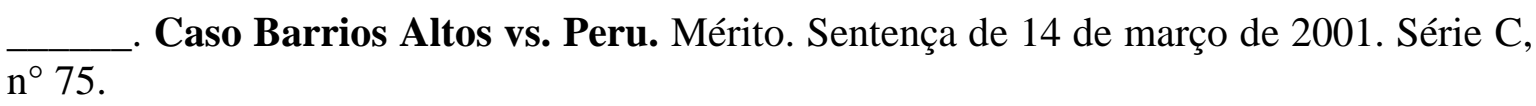

Almonacid Arellano y otros vs. Chile. Exceções preliminares, mérito, reparações e custas. Sentença de 26 de setembro de 2006. Série C, nº154.

Caso Gomes Lund e outros ("Guerrilha do Araguaia") vs. Brasil. Exceções preliminares, mérito, reparações e custas. Sentença de 24 de novembro de 2010. Série C, $\mathrm{n}^{\circ} 219$.

COUR PERMANENTE DE JUSTICE INTERNATIONALE. Procès-Verbaux des Séances du Comité. 16 juin-24 juillet 1920. Avec Annexes. La Haye: Van Langenhuysen Frères, 1920.

Statut de la Carélie orientale. Avis consultatif du 23 juillet 1923 . Série B, n 5 . 
Affaire des Concessions Mavrommatis en Palestine. Arrêt du 30 Août 1924. Série $\mathrm{A}, \mathrm{n}^{\circ} 20$.

Affaire des Concessions Mavrommatis en Palestine (Réadaptation). Arrêt du 10 octobre 1927 . Série A, ${ }^{\circ} 11$.

Affaire rélative au paiement, en or, des Emprunts Federaux Brésiliens Émis en France. Arrêt du 12 juillet 1929. Série A, nº 15.

Société Comerciale de Belgique. Arrêt du 15 juin 1939. Series A/B, nº 78.

. Compagnie d'eletricité de Sofia et de Bulgarie (mesures conservatoires). Ordonnance du 05 décembre 1939. Série A/B, nº 79.

DALLARI, Dalmo de Abreu. Elementos de Teoria Geral do Estado. 30. ed. São Paulo: Saraiva, 2011.

DALLARI, Pedro B. A. Constituição e relações exteriores. Prefácio de Celso Lafer. São Paulo: Saraiva, 1994.

Constituição e Tratados Internacionais. São Paulo: Saraiva, 2003.

DANIELE, Luigi. L'ordonnance sur la demande d'examen de la situation dans l'Affaires des Essais Nucléaires et le pouvoir de la Cour Internationale de Justice de régler sa prope procédure. Revue Générale de Droit International Public, 1996, t. C, pp. 653-71.

DELBEZ, Louis. Les príncipes généraux du contentieux international. Paris: LGDJ, 1969.

DINAMARCO, Cândido Rangel. Fundamentos do Processo Civil Moderno. São Paulo: Malheiros, tomo I, 2002.

DINH, Nguyen; DAILlER, Patrick; PELlET, Alain. Direito Internacional Público. Tradução de Vítor Marques Coelho. 2. ed. Lisboa: Fundação Calouste Gulbenkian, 2003.

DUPUY, Pierre-Marie. Le Juge et la Règle Générale. Revue Générale de Droit International Public, 1989, pp. 569-98.

L'unité de l'ordre juridique international: cours général de droit international public. RCADI, 297, 2002, v. 297. pp. 9-489.

Droit International Public. 9. ed. Paris: Dalloz, 2008.

DUPUY, René-Jean; VIGNES, Daniel. A handbook on the New Law of the Sea. Dordrecht/Boston/Lancaster: Martinus Nijhoff Publishers, 1991.

ÉCONOMIDÈS, Constantin P. La position du Droit International dans l'ordre juridique interne et la application des règles du Droit International par le juge national. Revue Hellénique de Droit International, $49^{\text {ème }}$ Année, n 1, 1996, pp. 207-16. 
EL OUALI, Abdelhamid. Effets Juridiques de la Sentence Internationale: contribution é l'etude de l'execution des normes internationales. Paris: LGDJ, 1984.

ENO, Robert Wundeh. The Jurisdiction of the African Court on Human and People's Rights. African Human Rights Law Journal, 2002, v. 2. pp. 223-33.

FAUCHILle, Paul. Traité de Droit Internacional Public. Tome $1^{\text {er }}$ Troisième Partie. Paix. 8 ed. Entièrement refondue, complétée et mise au courant, du Manuel de droit international public de M. Henry BONFILS. Paris: Roussau \& Cie, Editeurs, 1926.

FERRAJOLI, Luigi. A soberania no mundo moderno: nascimento e crise do Estado nacional. Tradução de Carlo Coccioli e Márcio Lauria Filho. Revisão da tradução de Karina Jannini. São Paulo: Martins Fontes, 2002.

FINCH, George A. Les sources modernes du droit international. RCADI, 1935-III, t. 53. pp. 531-629.

FONTOURA, Jorge. STF fortalece Tribunal Permanente de Revisão do Mercosul. Jornal Gazeta do Povo, $1^{\circ}$ de junho de 2012.

FRIEDMANN, Wolfgang. The changing structures of International Law. New York: Columbia University Press, 1964.

GARCIA, Fernando Silva. Derechos humanos: efectos de las sentencias internacionales. Ciudad del Mexico: Porrúa, 2007.

GARNER, James W. Les Devélopments et les Tendences Récentes du Droit International. RCADI, 1931-I, v. 35. pp. 605-720.

GAURIER, Dominique. Histoire du droit international. Auters, doctrines et développement de l'Antiquité à l'auber de la période contemporaine. Rennes Cedex: Presses Universitaires de Rennes, 2005.

GENTILI, Alberico. O direito da guerra: de jure belli. Trad. de Ciro Mioranza. Ijuí, RS: Ed. Unijuí, 2006.

GIARDINA, Andrea. La mise en oeuvre au niveau national des arrêts et des décisions internationaux. RCADI, 1979-IV, t. 165. pp. 233-352.

GOMES ROCHA, Francisco Ozanan. The International Tribunal for the Law of the Sea. Hamburgo: Universitätspublikationen, 2001.

GREIG, D. W. The Advisory Jurisdiction of the International Court and the Settlement of Disputes Between States. The International and Comparative Law Quarterly. April 1966, v. 15, pt. 2, April 1966.

GRIEVES, Forest. Supranationalism and international adjudication. Chicago: University of Illinois Press, 1960. 
GROSS, Leo. Participation of Individuals in Advisory Proceedings Before the International Court of Justice: Question of Equality Between the Parties. American Journal of International Law. January 1958, v. 52, n ${ }^{\circ}$. pp. 16-40.

GROTIUS, Hugo. O direito da guerra e da paz. Trad. de Ciro Mioranza. Florianópolis: Ed. Unijuí-Fondazione Cassamarca, 2004.

GUGGENHEIM, Paul. Les mesures conservatoires dans la procédure arbitrale et judiciaire. RCADI, 1932-II, t. 40. pp.645-764.

Traité de Droit international public. Genève: Librairie de 1’Université, Georg \& Cie S. A., 1954, tome II.

Contribution a L'histoire des Sources du Droit des Gens. RCADI, 1958-II, t. 94. pp.1-84.

HAMBRO, Edvard. The Jurisdiction of International Court of Justice. RCADI, 1950-I, t. 76. pp. 121-216.

The Authority of the Advisory Opinions of the International Court of Justice. The International and Comparative Law Quartely. January 1954, v. 3, pt. 1. pp. 7-22.

HART, H. L. A. O conceito de Direito. Pós-escrito organizado por Penelope A. Bullroch e Joseph Raz; tradução de Antônio Oliveira Sette-Câmara; revisão da tradução Marcelo Brandão Cipolla; revisão técnica Luiz Vergílio Dalla-Rosa. São Paulo: WMF Martins Fontes, 2009.

HIGGINS, Rosalyn. International Law and the Avoidance, Containment and Resolution of Disputes: General course on Public International Law. RCADI, 1991-V, t. 230. pp. 9-341.

HÖFFE, Otfried. A democracia no mundo de hoje. Tradução Tito Lívio Cruz Romão. São Paulo: Martins Fontes, 2005.

HUDSON, Manley O. Les avis consultatifs de la Cour Permanente de Justice Internationale. RCADI, 1925-III, t. 8. pp. 341-412.

International Tribunals Past and Future. Washington: Carnegie Endowment for International Peace and Brookings Institution, 1944.

INSTITUT DE DROIT INTERNATIONAL. Classification des conflits justiciables. Rapporteurs: MM. Philip Marshal Brown et Nicolas Politis. Session de Grenoble, 1922.

Interpretation of Peace Treaties with Bulgaria, Hungary and Romania. Advisory Opinion of march 3th, 1950.

Anglo-Iranian Oil Co. Case (United Kigdom v. Iran). Request for the indication of Interim Measures of Protection Order of July $15^{\text {th }} 1951$.

Haya de la Torre Case (Colombia/Peru). Judgment of 13 june 1951. 
Fisheries Case (United Kingdom v. Norway). Jugdgment of 18 december 1951.

Effect of Awards of Compensation Made by the United Nations Administrative Tribunal. Advisory Opinion of July $13^{\text {th }}$, 1954. Reports of Judgments, Advisory Opinions and Orders, 1954.

Interhandel Case (Switzerland v. United States of America). Request for the indication of Interim Measures of Protection. Order of October $24^{\text {th }} 1957$.

Fisheries Jurisdiction Case (Federal Republic of Germany v. Iceland). Request for the indication of Interim Measures of Protection. Order of August $17^{\text {th }} 1972$.

Nuclear Tests Case (Australia v. France). Request for the indication of Interim Measures of Protection. Order of June $22^{\text {nd }} 1973$.

Nuclear Tests Case (New Zeland v. France). Request for the indication of Interim Measures of Protection. Order of June $22^{\text {nd }} 1973$.

Nuclear Tests Case (Australia vs. France). Judgment of 20 December 1974. Reports of Judgments, Advisory Opinions and Orders, 1974.

. Case Concerning the Frontier Dispute (Burkina Faso/Republic of Mali). Judgment of 22 december 1986.

Case Concerning Application of the Convention on the Prevention and Punishment of the Crime of Genocide. (Bosnia and Herzegovina v. Yugoslavia). Further Requests for the Indication of Provisional Measures. Order of 13 September 1993.

L'activité du juge interne et les relations internationales. Rapporteur: $M$. Benedetto Conforti. Session de Milan, 1993.

Case Concerning the Gabcikovo-Nagymaros Project (Hungary/Slovakia). Judgment of 25 september of 1997.

Case Concerning the Vienna Convention on Consular Relations (Paraguay v. United States of America). Request for the indication of Interim Measures of Protection. Order of 9 april 1998.

La Grand Case (Germany v. United States of America). Request for the indication of Interim Measures of Protection. Order of 3 march 1999.

Le règlement judiciaire et arbitral des différends internationaux impliquant plus de deux Etats. Rapporteur M. Rudolf Benhardt. Session de Berlin, 1999. 2001.

La Grand Case (Germany v. United States of America). Judgment of 27 June

Legal consequences of the construction of a Wall in the Occupied Palestiniam Territory. Advisory Opinion of 9 july 2004. 
INTERNATIONAL CRIMINAL COURT. Pre-Trial Chamber I. Warrant of Arrest for Omar Hassan Ahmad Al-Bashir. 4 march 2009.

12 july 2010.

Pre-Trial Chamber I. Warrant of Arrest for Omar Hassan Ahmad Al-Bashir.

INTERNATIONAL LAW COMISSION. Draft Articles on Responsibility of States for Internationally Wrongful Acts, with commentaries. Yearbook of the International Law Commission, 2001, v. II, Part Two.

Fragmentation of International Law: Difficulties Arising from the Diversification and Expansion of International Law. Report of the Study Goup of the International Law Comission. Finalized by Martii Koskennieni. $58^{\text {th }}$ Session. Geneva, 3 July - 11 August 2006.

Draft Articles on Responsibility of International Organizations, with commentaries. Yearbook of the International Law Commission, 2011, v. II, Part Two.

INTERNATIONAL TRIBUNAL FOR THE LAW OF THE SEA. The M/V "Saiga" Case. Request for provisional measures. Order of 11 March 1998.

. The "Camouco" Case (Panama v. France). Application for Prompt Release. Judgment of 7 february 2000.

ISRAEL. Supreme Court of Israel Sitting as the High Court of Justice. Beit Sourik Villagi Council v. The Goverment of Israel. HCJ 2056/04. Judgment of 30 june 2004.

Supreme Court of Israel Sitting as the High Court of Justice. Mara'abe v. the Prime Minister of Israel. HCJ 7957/04. Judgment of 15 september 2005.

ITLOS. Tribunal Internacional para o Direito do Mar. Disponível em: < $\underline{\text { http://www.itlos. }}$ org >. Acesso em: 10 dez. 2013.

JESSUP, Philip C. Direito Transnacional. Tradução de Carlos Ramirez Pinheiro da Silva. São Paulo/Lisboa: Fundo de Cultura, 1956.

JORDISON, Sasha Maldonado. The Central American Court of justice: yesterday, today and tomorrow? Connecticut Journal of International Law. 2009-2010, v. 25, n. 183. p. 195.

KAMTO, Maurice. Les Interactions des Jurisprudences Internationales et des Jurisprudences Nationales. In: SOCIETÉ FRANÇAISE POUR LE DROIT INTERNATIONAL. La Jurisdictionnalisation du Droit International. Colloque de Lille. Paris: Pedone, 2003. pp. 393-460.

KANT, Immanuel. Ideia de uma História Universal de um ponto de vista cosmopolita. Organização Ricardo R. Terra; tradução Rodrigo Naves, Ricardo R. Terra. 2. ed. São Paulo: Martins Fontes, 2004. 
KARAGIANIS, Syméon. La multiplication des jurisdictions internationales: un systeme anarchique? In: SOCIETÉ FRANÇAISE POUR LE DROIT INTERNATIONAL. La Juridictionnaalisation du Droit International. Colloque de Lille. Paris: Pedone, 2003.

KELSEN, Hans. Principles of International Law. 2. ed. New York: Holt, Rinehart and Wiston, 1966.

The Law of United Nations: a critical analysis of its fundamental problems. New Jersey: The Lawbook Exchange, LTI, 2000.

Teoria pura do direito. Tradução João Baptista Machado. 8. ed. São Paulo: WMF Martins Fontes, 2009.

A paz pelo direito. Tradução Lenita Ananias do Nascimento. São Paulo: WMF Martins Fontes, 2011.

KINDER-GEST, Patrícia. Manuel de droit anglais. I. Institutions Politiques et Judiciaires. Paris: L.G.D.J., 1989.

KLEIN, Natalie. Dispute Settlement in the UN Convention on the Law of the Sea. Cambridge: Cambridge University Press, 2005.

KNOOPS, Geert-Jan Alexander; AMSTERDAN, Robert R. The duality of State Cooperation within International and National Criminal Cases. Fordham International Law Journal, 2006-2007, v. 30. pp. 260-95.

KOFF, Serge. Introduction a L'histoire du Droit International. RCADI, 1923, t. 1. pp. $5-23$.

KOLB, Robert. La Bonne foi en Droit International Public. Contribuition à l'étude des principes généraux de droit. Paris: PUF, 2000.

KOVACS, Péter. Developpement et Limites de la Jurisprudence en Droit International. In: SOCIETE FRANÇAISE POUR LE DROIT INTERNATIONAL. La Jurisdictionnalisation du Droit International. Colloque de Lille. Paris: Pedone, 2003. pp. 269-341.

KRESS, Claus. The International Criminal Court as a Turning Point in the History of International Criminal Justice. In: CASSESE, Antonio (Ed.). The Oxford Companion to International Criminal Justice. New York: Oxford University Press, 2009.

LA PRADELLE, Géraud de Geouffre de. La fonction des jurisdicions de l'ordre international. Journal du Droit International, 1998, 125 année, n. 2. pp. 389-429.

LAFER, Celso. A internacionalização dos direitos humanos: Constituição, racismo e relações internacionais. Barueri: Manole, 2005.

LAGHMANI, Slim. Histoire du droit des gens: du jus gentium impérial au jus publicum europaeum. Paris: Éditions A. Pedone, 2003. 
LAUTERPACHT, H. La Théorie des Différends non Justiciables en Droit International. RCADI, 1930-IV, t. 34. pp. 493-654.

1933.. The Function of Law in the International Community. Oxford: Claredon Press, LENZ, Carl Otto. The role and mechanism of the Preliminary Ruling Procedure. Fordham International Law Journal, 1994-1995, v. 18. pp. 388-409.

LIMBURG, J. L'autorité de chose jugée des décisions des jurisdictions internationales. RCADI, 1929-V, t. 30. pp. 519-618.

LOWE, Vaughan. Jurisdiction. In: EVANS, Malcolm D. International Law. New York: Oxford University Press, 2003.

MABYE, Kéba. L'intérêt pour agir devant la Cour internationale de Justice. RCADI, 1988-II, t. 209. pp. 316-318.

MAEOKA, Érika. O acesso à Justiça e os desafios à implementação das sentenças da Corte Interamericana de Direitos Humanos. Dissertação de Mestrado. Universidade Estadual de Londrina, 2009.

. Os comentários ao Projeto de Lei 4.667, de 2004, e os limites à eficácia interna das Sentenças Internacionais. In: MENEZES, Wagner. Direito Internacional em Expansão. Belo Horizonte: Arraes, 2012, v. 1. pp. 365-76.

MAGAlHÃES, José Carlos de. O Supremo Tribunal Federal e o Direito Internacional: uma análise crítica. Porto Alegre: Livraria do Advogado, 2000.

MAIA, Catherine. Le Jus Cogens dans la Jurisprudence de la Cour Interamericaine des Droits de L'Homme. In: HENNEBEL, Ludovic; TIGROUDJA, Hélène. Les particularisme interamericain des droits de l'homme. En l'honneur du $40^{\mathrm{e}}$ anniversaire de la Convention américaine des droit de l'homme. Paris : Pedone, 2009.

MANN, F. A. The doctrine of jurisdiction in international law. RCADI, 1964, t. 111. pp. 1-162.

The doctrine of international jurisdiction revisited after twenty years. RCADI, 1984, t. 187. pp. 9-116.

MC WHINNEY, Edward. Judicial settlement of disputes: jurisdiction and justiciability. RCADI, 1990-II, t. 221. pp. 9-194.

MELlO, Celso D. de Albuquerque. Direito Constitucional Internacional: uma introdução. Constituição de 1988 revista em 1994. Rio de Janeiro: Renovar, 1994.

Curso de Direito Internacional Público. 14 ed. Revista e ampliada. Rio de Janeiro: Renovar, 2002, v. I. 
MENDES, Gilmar Ferreira; BRANCO, Paulo Gustavo Gonet. Curso de Direito Constitucional. 8. ed. rev. e atual. São Paulo: Saraiva, 2013.

MENEZES, Wagner. Ordem global e transnormatividade. Ijuí: Ed. Unijuí, 2005.

Derecho Internacional en América Latina. Traducción de Ana Carolina Izaga de Senna Ganem. Brasília: FUNAG, 2010.

A Jurisdicionalização do Direito Internacional: conflitos de competência entre Tribunais Internacionais, mecanismos de prevenção e resolução. Tese de Livre-docência apresentada à Faculdade de Direito da Universidade de São Paulo (FDUSP), 2012.

. Tribunais Internacionais: jurisdição e competência. São Paulo: Saraiva, 2013.

MERCOSUL. Laudo do Tribunal Arbitral ad hoc do Mercosul constituído para entender a controvérsia apresentada pela República Oriental do Uruguai à República Federativa do Brasil sobre "Proibição de Importação de Pneumáticos Remoldados (Remolded) Procedentes de Uruguai". Adotado em Montevidéu, no dia 09 de janeiro de 2002. Disponível em: http://www.stf.jus.br/arquivo/cms/processoAudienciaPublicaAdpf 101/anexo/LaudodoTribunalArbitralAdHocdoMERCOSUL.pdf . Acesso em: 28 dez. 2013.

MINISTÉRIO PÚBLICO FEDERAL. Nota Técnica ao Projeto de Lei n ${ }^{\circ}$.667, de 2004. Elaborada pelos Procuradores Regionais da República André de Carvalho Ramos, Denise Neves Abade, Geisa de Assis Rodrigues e Robério Nunes dos Anjos Filho. 3 de agosto de 2010

Procuradoria Geral da República. I Workshop Internacional sobre Justiça de Transição: os efeitos domésticos da decisão da Corte Interamericana de Direitos Humanos no Caso Gomes Lund e outros vs. Brasil e as atribuições do Ministério Público Federal. 2a Câmara de Coordenação e Revisão, Documento n²/2011, 3 de outubro de 2011.

MIRKINE-GUETZÉVITCH, Boris. Droit International et Droit Constitutionel. RCADI, 1931-IV, t. 38. pp. 307-465.

Le Droit Constitutionnel et l'organisation de la paix. RCADI, 1933-III, t. 45. pp. 667-773.

MORELLI, Gaetano La Sentenza Internazionale. Padova: CEDAM - Casa Editrice Dott. Antonio Milani, 1931.

. Nozioni di Diritto Internazionale. 7. ed. riveduta. Padova: CEDAM - Casa Editrice Dott. Antonio Milani, 1967.

MOSLER, H. L'application du droit international public par les tribunaux nationaux. RCADI, 1957-I, t. 91. pp. 619-711.

NAPOLITANO, Silvina S. Gonzáleas. Las medidas provisionales en Derecho Internacional ante las Cortes y Tribunales Internacionales. Buenos Aires: La Ley, 2004. 
NASCIMENTO E SILVA, G. E. Direito Internacional no Projeto de Reforma da Constituição. Boletim da Sociedade Brasileira de Direito Internacional, Ano XXII, N ${ }^{\circ} 43$ e 44, Janeiro-Dezembro 1996, pp. 5-21.

; CASELLA, Paulo Borba; BITTENCOURT NETO, Olavo de Oliveira. Direito Internacional Diplomático: Convenção de Viena sobre Relações Diplomáticas na teoria e na prática. 4.ed. rev. atual. e ampl. São Paulo: Saraiva, 2012.

NÉGULESCO, Démètre. L'evolution de la procédure des avis consultatifs de la Cour Permanente de Justice Internationale. RCADI, 1936-III, t. 57. pp. 1-96.

NEVES, Marcelo. Transconstitucionalismo. São Paulo: WMF Martins Fontes, 2009.

NOLLKAEMPER, André. National Courts and the International Rule of Law. Oxford: Oxford University Press, 2012.

NYS, Ernest. Les Origines du Droit International. Bruxelles: Alfred Castaigne, 1894.

OELLERS-FRAHM, Karin. Interim Measures of Protection. In: BERNHARDT, Rudolf (Ed.). Encyclopedia of Public International Law. Settlement of Disputes. Amsterdam New York - Oxford: North Holland Publishing Company, 1981, v. I.

PANNUNZIO, Eduardo. A judicialização das relações internacionais no Brasil em face do princípio constitucional da prevalência dos direitos humanos. Tese de doutorado. Faculdade de Direito da Universidade de São Paulo, 2012.

PASTOR RIDRUEJO, José Antonio. Le droit international à la veille du vingt et unième siècle: normes, faits et valeurs: cours général de droit international public. RCADI, 1998, t. 274. pp. 9-308.

PAUWELYN, Joost. Enforcement and Countermesures in the WTO: Rules are Rules Toward a More Collective Approach. The American Journal of International Law. 2000, v. 94, n. 2. pp. 335-47.

PESCATORE, Pierre. Les mesures conservatoires et les referes. In: SOCIETÉ FRANÇAISE DE POUR LE DROIT INTERNATIONAL. Juridiction Internationale Permanente. Colloque de Lyon. Paris: Pedone, 1987. pp. 315-62.

PETERSMAN, Ernest-Ulrich. The GATT/WTO Dispute Settlement System. International Law, International Organizations and Dispute Settlement. London, Hague, Boston: Kluwer Law International, 1997.

PIOVESAN, Flávia. Direitos humanos e Direito Constitucional Internacional. 7. ed. rev., ampliada e atualizada. São Paulo: Saraiva, 2006.

Direitos humanos e Justiça Internacional. Um estudo comparativo dos sistemas regionais europeu, interamericano e africano. São Paulo: Saraiva, 2006. 
; IKAWA, Daniela Ribeiro. O Tribunal Penal Internacional e o Direito Brasileiro. In: PIOVESAN, Flávia. Temas de direitos humanos. 3. ed. São Paulo: Saraiva, 2009. p. 167.

RAMOS, André de Carvalho O Estatuto do Tribunal Penal Internacional e a Constituição Brasileira. In: CHOUKR, Fauzi Hassam; AMBOS, Kai (Orgs.). Tribunal Penal Internacional. São Paulo: Revista dos Tribunais, 2000.

Direitos humanos em juízo: comentários aos casos contenciosos e consultivos da Corte Interamericana de Direitos Humanos e o estudo da implementação dessas decisões no Direito Brasileiro. São Paulo: Max Limonad, 2001.

Responsabilidade Internacional por violação de direitos humanos: seus elementos, a reparação devida e sanções possíveis: teoria e prática do direito internacional. Rio de Janeiro: Renovar, 2004.

Direitos humanos na integração econômica. Análise comparativa da proteção de direitos humanos e conflitos jurisdicionais na União Europeia e Mercosul. Rio de Janeiro: Renovar, 2008.

O diálogo das Cortes: o Supremo Tribunal Federal e a Corte Interamericana de Direitos Humanos. In: AMARAL JUNIOR, Alberto do; JUBILUT, Liliana Lyra (Orgs.). O STF e o Direito Internacional dos Direitos Humanos. São Paulo: Quartier Latin do Brasil, 2009. pp. 805-50.

Rule of Law e a Judicialização do Direito Internacional: da Mutação Convencional às Guerras Judiciais. In: BEDIN, Gilmar Antonio. Estado de Direito, Jurisdição Universal e terrorismo: levando o Direito Internacional a sério. Ijuí: Ed. Unijuí, 2009. pp. 85-122.

Crimes da ditadura militar: a ADPF 153 e a Corte Interamericana de Direitos Humanos. In: GOMES, Luis Flávio; MAZZUOLI, Valério de Oliveira. Crimes da ditadura militar. Uma análise à luz da jurisprudência atual da Corte Interamericana de Direitos Humanos: Argentina, Brasil, Chile e Uruguai. São Paulo: Revista dos Tribunais, 2011. pp. 174-225.

Pluralidade das ordens jurídicas: a relação do direito brasileiro com o direito internacional. Curitiba: Juruá, 2012.

Teoria geral dos direitos humanos na Ordem Internacional. 2. ed. São Paulo: Saraiva, 2012.

Processo Internacional de Direitos Humanos. Análise dos sistemas de apuração de violações de direitos humanos e a implementação das decisões no Brasil. São Paulo: Saraiva, 2012.

A pluralidade de ordens jurídicas e a nova centralidade do Direito Internacional. Boletim da Sociedade Brasileira de Direito Internacional. Ano XCVIII, ago/dez. 2013, v. 1, n. 119-24. pp. 19-45. 
RANGEL, Vicente Marotta. Direito e Relações Internacionais. 8. ed. rev., atualizada e ampliada. São Paulo: Revista dos Tribunais, 2005.

Jurisdição Internacional: Considerações Preambulares. Estudos em Homenagem à Professora Doutora Isabel de Magalhães Colasso. Coimbra: Almedina, 2007. pp. 643-52.

RAUB, Lindsay. Positioning Hybrid Tribunals in International Criminal Justice. New York University International Law and Politics Journal, 2009, v. 41. pp. 1013-53.

RECONDO, Felipe; ARRUDA, Roldão. Decisão da OEA abre debate sobre STF. Jornal O Estado de São Paulo. Disponível em: <http://www.estadao.com.br/noticias/nacional, decisao-da-oea-abre-debate-sobre-stf,654133,0.htm>. Acesso em: 30 dez. 2013.

REPÚBLICA ARGENTINA. Corte Suprema de Justicia de la Nación. Recurso de Hecho S. 1767 XXXVIII. 14 de junio de 2005.

REPÚBLICA DO PERU. Tribunal Constitucional. Colegio de Abogados del Callao (demandante) c. Congreso de la República (demandado). Resolución del 19 junio de 2007.

REUTER, Paul. Droit international public. Paris: Presses Universitaires de France, 1993.

ROCHA, Francisco Ozanan Gomes. The International Tribunal for the Law of the Sea. Hamburgo: Universitätspublikationen, 2001. p. 60.

ROMANO, Cesare P.R. The proliferation of international judicial bodies: the pieces of the puzzle. New York University International Law and Politics, 1999, v. 31. pp. 709-51.

. The shift from the consensual to the Compulsory Paradigm in International Adjudication: elements of a Theory of Consent. Journal of International Law and Politics. New York University, 2007, v. 39, n. 791.

Deciphering the Grammar of the International Jurisprudential Dialogue. New York University International Law and Politics Journal, 2009, v. 41. pp. 755-87.

ROSENNE, Shabtai. L'exécution et la mise en vigueur des décisions de la Cour Internationale de Justice. Revue Générale de Droit International Public, 1953, t. LVII. pp. 532- 83.

Sijthoff, 1965.

The Law and Practice of the International Court. Vol. II. Leyden: A. W.

Practice and Methods of International Law. London-Rome-New York: Oceana Publications, INC., 1984.

The Hauge Peace Conferences of 1899 and 1907 and International Arbitration. Reports and Documents. The Hauge: T.M.C. Asser Press, 2001.

SALMON, Jean. La Convention Européenne pour le Réglement Pacifique des Différends. Revue Générale de Droit International Public, 1959, t. LXIII, pp. 21-64. 
SALVIOLI, Gabriele. La jurisprudence de la Cour Permanente de Justice Internationale. RCADI, 1926-II, t. 12. pp. 1-114.

SCELLE, Georges. Règles générales du droit de la paix. RCADI, 1933-IV, t. 46. pp. 327-703. Sirey, 1934.

; Précis de Droit des Gens. Principes et Systématique. 2eme partie. Paris: Recueil

SCHACHTER, Oscar. The Enforcement of International Judicial and Arbitral Decisions. The American Journal of International Law, v. 54, 1960, pp. 1-24.

SCHINDLER, Diètrich. Les Progrès de L'Arbitrage Obligatoire. Depuis la Création de la Société des Nations. RCADI, 1928-V, t. 25. pp. 233-364.

SCHLOSSER, Peter. Jurisdiction and international judicial and administrative cooperation. RCADI, 2000, t. 284. pp. 9-428.

SCHREUER, Christoph H. The Implementation of International Judicial Decisions by Domestic Courts. The International and Comparative Law Quartely, 1975, v. 24,p. 153-183.

SEABED DISPUTES CHAMBER OF THE INTERNATIONAL TRIBUNAL FOR THE LAW OF THE SEA. Responsabilities e obligations of States sponsoring persons and entities with respect to activities in the Area. Advisory Opinion, 1 February 2011. List of cases $n^{\circ} 17$.

SHANY, Yuval. No longer a weak department of power? Reflections on the Emergence of a New International Judiciary. European Journal of International Law, 2009, v. 20, n. 1. pp. 73-91.

Regulating jurisdictional relations between national and international courts. Oxford/New York: Oxford University Press, 2009.

SHAW, Malcolm. International Law. 6th.ed. Cambridge: Cambridge University Press, 2010.

SILVA, José Afonso da. Curso de Direito Constitucional Positivo. 27. ed. rev. e atualizada (até a Emenda Constitucional n. 52.). São Paulo: Malheiros, 2006.

SILVA, Virgílio Afonso da. Integração e diálogo constitucional na América do Sul. In: BOGDANDY, Armin von; PIOVESAN, Flávia; ANTONIAZZI, Mariela Morales (Orgs.). Direitos humanos, democracia e integração jurídica na América do Sul. Rio de Janeiro: Lumen Juris, 2010. pp. 515-30.

SLAUGHTER, Anne-Marie. A tipology of transjudicial communication. University of Richmond Law Review, 1994, v. 29. pp. 99-137. 

708-12.

Court to Court. American Journal of International Law, 1998, v. 92, n. 4. pp.

A global community of courts. Harvard International Law Journal, 2003, v. 44. pp. 191-219.

SOARES, Guido Fernandes Silva. Das imunidades de jurisdição e de execução. Rio de Janeiro: Forense, 1984.

Direito Internacional do meio ambiente: emergência, obrigações e responsabilidades. São Paulo: Atlas, 2001.

Curso de Direito Internacional Público. São Paulo: Atlas, 2002, v. 1. p. 98.

A proteção internacional do meio ambiente. Barueri, SP: Manole, 2003.

SOCIETÉ FRANÇAISE DE POUR LE DROIT INTERNATIONAL. Juridiction Internationale Permanente. Colloque de Lyon. Paris: Pedone, 1987.

Pedone, 2003.

La Juridictionnalisation du Droit International. Colloque de Lille. Paris:

SORENSEN, Max (comp). Manual de Derecho Internacional Público. 11. ed. rev. e adiciones de Bernardo Sepúlveda. México: FCE, 2010.

SUPERIOR TRIBUNAL DE JUSTIÇA. Carta Rogatória n 438-BE. Rel. Min. Luiz Fux. Julgado em 24.09.2007.

SUPREMO TRIBUNAL FEDERAL. RE 80.004. Rel. Min. Xavier de Albuquerque. Julgado em 01. 06. 1977.

. Ação Direta de Inconstitucionalidade n ${ }^{\circ}$ 1480/DF - Medida Cautelar em Ação Direta de Inconstitucionalidade. Min. Rel. Celso de Mello. Julgado em 04.09.1997.

RE 222.368. Rel. Min. Celso de Mello. Julgado em 30.04.2002.

Extradição 954/Itália. Requerente: Governo da Itália. Extraditando: Marcel Van den Berg. Julgado em 07.06.2006.

RE 466.343. Rel. Min. Cesar Peluso. Julgado em 03.12.2008.

RE 511.961. Rel. Min. Gilmar Mendes. Julgado em 17.06.2009.

. Arguição de Descumprimento de Preceito Fundamental $n^{\circ}$ 101/ DF. Min. Rel. Carmen Lúcia. Julgado em 24.06.2009.

Petição 4.625/ República do Sudão. Requerente: Tribunal Penal Internacional (Estatuto de Roma). Requerido: Omar Hassan Ahmad Al Bashir (Presidente do Sudão). Rel. Min. Rosa Webber. Decisão monocrática do Presidente em exercício Min. Celso Mello, publicada em 04.08.2009. 
Arguição de Descumprimento de Preceito Fundamental $n^{\circ}$ 153/DF. Min. Rel. Eros Grau. Julgado em 24.04.2010.

Emenda Regimental $\mathbf{n}^{\circ}$ 48. Aprovada em 3 de abril de 2012, passim.

TAUBE, Le Baron Michel de. Les origines de L'Arbitrage International. Antiquité et Moyen Age. RCADI, 1932-IV, t. 42. pp. 1-115.

TEITEL, Ruti ; HOWSE, Robert. Cross-Judging: tribunalization in a fragmented but interconnected global order. New York University International Law and Politics Journal, 2009, v. 41. pp. 959-90.

TOMUSCHAT, Christian. International Courts and Tribunals. Max Planck Encyclopedia of Public International Law, 1981, v. 1.

International Law: ensuring the survival of mankind on the eve of a new century. RCADI, 1999, t. 281. pp. 9-438.

TREVES, Tulio. Diritto Internazionale. Problemi Fondamentali. Milano: Giuffrè Editore, 2005. p. 643.

TRIBUNAL PERMANENTE DE REVISÃO DO MERCOSUL. Opinião Consultiva 1/2007. Parecer de 3 de abril de 2007.

TRIFFTERER, Otto (Ed.). Commentary on the Rome Statue of International Criminal Court. Observers' Notes, Article by Article. 2nd. ed. Münich: C. H. Beck - Hart - Nomos, 2008. p. 1540.

TRUYOL Y SERA, Antonio. Genèse et structure de la société internationale. RCADI, 1959-I, t. 96. pp. 553-642.

. Historia del Derecho Internacional Público. Version española de Paloma García Picazo. Madrid: Tecnos, 1998.

TUNCEL, E. L'execution des décisions de la C.I.J. selon la Charte des Nations-Unies. Thèse: Nêuchatel, 1960.

TZANAKOPOULOS, Antionios. Domestic Courts in International Law: the International Judicial Function of National Courts. Loyola of Los Angeles International and Comparative Law Review, 2011, v. 34, n. 133. pp. 133-168.

UNITED STATES OF AMERICA. Supreme Court. Breard v. Greene. 523 US. 371 (1998).

UNITED STATES OF AMERICA. Supre Court. Federal Republic of Germany et al. v. United States et al. 526 US 111 (1999).

UNITED NATIONS. United Nations Millenium Declaration. Resolution adpted by the General Assembly (A/55/L.2). 18 september 2000. 
Security Council. Resolution 1.593 (2005). 5158th meeting, 31 march 2005.

The rule of law at the national and international levels. Resolution adopted by the General Assembly (A/61/456). 18 December 2006. august 2012.

Report of the International Criminal Court. General Assembly (A/67/308). 14 2013.

Report of the International Criminal. General Assembly. (A/68/314). 13 august

VALLADÃO, Haroldo. O Direito Internacional no Projeto da Constituição. Boletim da Sociedade Brasileira de Direito Internacional. Ano II, $\mathrm{n}^{\circ}$ 3, jan.-jun. 1946, pp. 7-17.

VAUCHER, Marius. Le problème de la justiciabilité et de la non-justiciabilité en droit international des différend dits "politiques" ou "non-juridiques" et Les notions de compétence exclusive et de compétence nationale (Article 15, $\S 8$ du Pacte de la S.d.N. et article 2, § 7 de la Charte de l'ONU). Paris: Pedone, 1951.

VELASCO, Manuel Diez de. Instituiciones de Derecho Internacional Público. 15. ed. Madrid: Tecnos, 2005.

VERGUEIRO, Luiz Fabrício Thaumaturgo. Implementação da Cooperação Jurídica Internacional Vertical. Tese de doutorado. Universidade de São Paulo, São Paulo, 2012.

VILLALPANDO, Santiago. L'érmergence de la communauté internationale dans la responsabilité des Etats. Paris: PUF, 2005.

VILLANI, Ugo. In tema di indicazione di misure cautelari da parte della Corte Internazionale di Giustizia. Rivista di Diritto Internazionale. Anno 1974, v. LVII. pp. 657-81.

VIRALLY, Michel. Le Champ Opératoire du Réglement Judiciaire International. Revue Générale de Droit International Public, 1983. pp. 281-314.

VISSCHER, Charles de. Les avis consultatifs de la Cour permanente de justice internationale. RCADI, 1929-I, t. 26. pp. 1-76.

Les tendances internationales des constitutions modernes. RCADI, 1952-I , t. 80. pp. 511-78.

Théories et réalités em Droit International Public. 4. ed. Revue et mise à jour. Paris: Pedone, 1970.

VITÓRIA, Francisco de. Os índios e o direito da Guerra. Trad. de Ciro Mioranza. Ijuí: Ed. Unijuí, 2006.

VULCAN, Constantin. L'exécution des décisions de la Cour Internationale de Justice d'après la Charte des Nations Unies. Revue Générale de Droit Internationale Public, 1947, t. XVIII. pp. 187-205. 
WALDOCK, Humphrey. General course on public international law. RCADI, 1962-II, t. 106. pp. 1-251.

WEHBERG, Hans. La contribution des Conférences de la Paix de la Haye au Progrès du Droit International. RCADI, 1931-III, t. 37. pp. 527-669.

WEIL, Prosper. Le droit international en quete de son identité: Cours Général de Droit International Public. RCADI, 1992-VI, t. 237. pp. 9-370.

WORLD TRADE ORGANIZATION. Brazil - Measures Affecting Imports of Retreaded Tyres. Report of the Appellate Body. AB-2007-4. WT/DS332/AB/R. 3 december 2007.

ZIMMERMAN, Andreas; TOMUSCHAT, Christian; OELLERS-FRAHM, Karin (Edit.). The Statue of the International Court of Justice. A commentary. New York: Oxford University Press, 2006. p. 784.

ZOLLER, Elizabeth. La Bonne Foi en Droit International Public. Paris: Pedone, 1977. 